\title{
De afnamekwaliteit van cervixuitstrijkjes
}

Citation for published version (APA):

Buntinx, F. (1992). De afnamekwaliteit van cervixuitstrijkjes. [Doctoral Thesis, Maastricht University]. Thesis Publishers. https://doi.org/10.26481/dis.19920220fb

Document status and date:

Published: 01/01/1992

DOI:

10.26481/dis.19920220fb

Document Version:

Publisher's PDF, also known as Version of record

\section{Please check the document version of this publication:}

- A submitted manuscript is the version of the article upon submission and before peer-review. There can be important differences between the submitted version and the official published version of record.

People interested in the research are advised to contact the author for the final version of the publication, or visit the DOI to the publisher's website.

- The final author version and the galley proof are versions of the publication after peer review.

- The final published version features the final layout of the paper including the volume, issue and page numbers.

Link to publication

\footnotetext{
General rights rights.

- You may freely distribute the URL identifying the publication in the public portal. please follow below link for the End User Agreement:

www.umlib.nl/taverne-license

Take down policy

If you believe that this document breaches copyright please contact us at:

repository@maastrichtuniversity.nl

providing details and we will investigate your claim.
}

Copyright and moral rights for the publications made accessible in the public portal are retained by the authors and/or other copyright owners and it is a condition of accessing publications that users recognise and abide by the legal requirements associated with these

- Users may download and print one copy of any publication from the public portal for the purpose of private study or research.

- You may not further distribute the material or use it for any profit-making activity or commercial gain

If the publication is distributed under the terms of Article $25 \mathrm{fa}$ of the Dutch Copyright Act, indicated by the "Taverne" license above, 
DE AFNAMEKWALITEIT VAN CERVIXUITSTRIJKJES 
Het onderzoek, waarop dit proefschrift steunt, werd mogelijk gemaakt door de financiële steun van het Praeventiefonds (project nr. 28-1872) en van het Vlaams Huisartsen Instituut.

De uitgave van dit proefschrift werd mogelijk gemaakt door de financiele steun van E. Merck Nederland B.V. te Amsterdam. 


\title{
De afnamekwaliteit van cervixuitstrijkjes
}

\author{
Proefischrift \\ ter verkrijging van de graad van doctor \\ aan de Rijksuniversiteit Limburg te Maastricht, \\ op gezag van de Rector Magnificus, \\ Prof. imr. M.J. Cohen, \\ volgens het besluit van het College van Dekanen, \\ in het openbaar te verdedigen \\ ap donderdag 20 februari 1992 om 16.00 uur
}

door

Frank Buntinx geboren te Hasselt

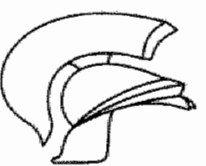


Promotoren: Prof. dr. J.A. Knottnerus

Prof. dr. H.F.J.M. Crebolder

Prof. dr. G.G.M. Essed

Beoordelingscommissie: Prof. dr. P.G. Knipschild, voorzitter Prof. dr. J.W. Arends

Prof. dr. J. de Haan

Prof. dr. J. Heyrman

Prof. dr. E. Reerink 
Want dat is wetenschap jezelf verwonderen over de wereld om je heen, proberen om er vat op te krijgen, door te onderzoeken wat er gebeurt als je dit of dat doet, en genieten van het resultaat.

P. Van Dooren. 


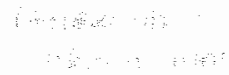

(

.

$\therefore \quad \therefore$ 


\section{INHOUD}

AFKORTINGEN

TEN GELEIDE

INLEIDING

DEEL

LITERATUURSTUDIE

1. Op zoek naar uitstrijkjes van goede kwaliteit

2. Invloed van geografische factoren op de afnamekwaliteit van cervixuitstrijkjes

3. Literatuuroverzichten en meta-analyse - methodologische kanttekeningen

DEEL III

VERBETERING VAN DE AFNAMEKWALITEIT VAN CERVIXUITSTRIJKJES

4. Cervixuitstrijkjes: afnamegewoonten en ervaringen

5. Afnamekwaliteit van cervixuitstrijkjes: een beschrijvend onderzoek

6. Verband tussen kwaliteitskenmerken en pathologie bij cervixuitstrijkjes 105

7. Interobserver variatie in het beoordelen van kwaliteitsindicatoren bij cervixuitstrijkjes

8. Invloed van verschillende vormen van feed-back op de afnamekwaliteit van cervixuitstrijkjes. Een gecontroleerde en gerandomiseerde interventiestudie

9. Reacties van artsen op verschillende vormen van feed-back ter verbetering van de afnamekwaliteit van cervixuitstrijkjes

DEEL III

DE ROL VAN PLAVEISELCELLEN IN CERVIXUITSTRIJIKJIES

10. Voorkomen van verschillende celtypen in uitstrijkjes, afgenomen met de spatel, de Cytobrush en de combinatie van spatel en Cytobrush

11. Verband tussen erythroplakie en de aanwezigheid van verschillende celtypen in het cervixuitstrijkje 


\section{BIJLAGEN}

1. Formulieren gebruikt voor maandoverzichten van de interventiestudie in groep $C$ en $D$

2. Verschillende classificaties voor cytologische afwijkingen 


\section{AFKORTINGEN}

$95 \%$ Bl: $\quad 95 \%$ betrouwbaarheidsinterval

Cbr.: $\quad$ Cytobrush (uitstrijkjes gemaakt met de -1

C.I.S.: $\quad$ Carcinoma in Situ

Endo(-): $\quad$ Aantal of percentage uitstrijkjes waarbij geen endocervicale cellen gevonden worden

Endocerv.: Endocervicalle cellen

Ext. tip sp.: Extended-tip spatel

Multisp.: Multispatula

OR: Odds ratio

$\mathrm{OR}_{\mathrm{mh}}: \quad$ Gepoolde odds ratio volgens Mantel-Haenszel

$\mathrm{OR}_{\mathrm{mh}}$ (Rand): Gepoolde odds ratio, alleen rekening houdend met gerandomiseerde studies

Random.?: Is de toewijzing gerandomiseerd verlopen?

Ref: $\quad$ Referentie

RR: $\quad$ Relatief Risico (Relative Risk)

RR mh: Gepoold relatief risico volgens Mantel-Haenszel

Sp: $\quad$ Spatel (uitstrijkjes gemaakt met een -)

Spatel SS: Eén afname met het scherpe uiteinde en een andere afname met het stompe uiteinde van een gecombineerde spatel.

Sp. v. Ayre: Spatel van Ayre (uitstrijkjes gemaakt met -1

Tot.aant: Totaal aantal

Tot.uit.: Totaal aantal uitstrijkjes tijdens de interventieperiode.

Uitstr.: $\quad$ Uitstrijkjes

Watt: Wattenstok (uitstrijkjes gemaakt met de -)

WHO: $\quad$ World Health Organisation 
का

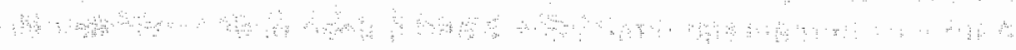




\section{TEN GELEIDE}

Toen wij 10 jaar geleden begonnen met onderzoek over cervixuitstrijkjes was dit omdat er binnen de Maasmechelse huisartsengroep behoefte bestond aan inzicht in het aantal uitstrijkjes dat huisartsen jaarlijks bij hun patiënten afnamen en in het aantal vrouwen binnen de gemeente dat jaarlijks een uitstrijkje kreeg. Dankzij de medewerking van de cytologen van de verschillende laboratoria die in de streek aktief waren, slaagden wij erin een precies beeld te krijgen van het aantal uitstrijkjes dat bij Maasmechelse vrouwen tijdens de normale praktijkvoering afgenomen werd en van de rol van huisartsen en gynaecologen (Buntinx e.a. 1984). We beschikten daardoor over een unieke basismeting voor vergelijkend onderzoek. Toen enkele jaren later een campagne gevoerd werd in de gemeente om vrouwen te stimuleren tot het laten maken van cervixuitstrijkjes, was de uitdaging dan ook groot om via een tweede, nu prospectief registratie-onderzoek het effect van deze interventie te schatten (Buntinx e.a. 1987a en b en 1989 b).

Reeds tijdens deze eerste studies was er interesse ontstaan voor de afnamekwaliteit van cervixuitstrijkjes. Op dat ogenblik waren we vooral geinteresseerd in de vergelijking van de afnamekwaliteit van uitstrijkjes gemaakt door huisartsen en door gynaecologen. In latere jaren werd het begrip afnamekwaliteit verder geoperationaliseerd en groeide de belangstelling hiervoor. Informele kontakten en een aantal publicaties uit het Nederlandse taalgebied leerden ons dat er aan die afnamekwaliteit wellicht veel te verbeteren was. Daaruit ontstond het plan om via een interventie te proberen deze afnamekwaliteit te verbeteren en het effect hiervan te volgen via een gerandomiseerde en gecontroleerde interventiestudie. Het Centraal Laboratorium te Antwerpen, één van de grotere cytologische diensten in Vlaanderen, walmee ook in de wroegere studies was samengewerkt, bleek geïnteresseerd en bereid om hieraan mee te werken.

In dit proefschrift vindt $U$ de beschrijving van verschillende onderdelen van deze interventiestudie en een aantal daarvan afgeleide onderzoeken.

Dit proefschrift beperkt zich tot aspecten van de afnamekwaliteit van cervixuitstrijkjes. Veel belangrijke epidemiologische studies zijn op het gebied van cervixscreening verricht. Niettemin zijn veel vragen op dit terrein nog onvoldoende beantwoord. Teneinde te kunnen werken op een voldoende scherp omschreven terrein, zijn wij in dit proefschrift op deze epidemiologische aspecten niet ingegaan. Overigens achten wij het niet onaannemelijk dat het controleren voor de afnamekwaliteit van de cervixuitstrijkjes een belangrijke invloed zou kunnen hebben op de resultaten van epidemiologisch onderzoek.

Een aantal hoofdstukken wit dit proefschrift is oorspronkelijk in artikelvorm geschreven. Dit heeft tot gevolg dat herhalingen niet volledig te vermijden waren. Voor de literatuurreferenties in de tekst hebben wij gekozen voor het vermelden 
var de naam van de eerste auteur, zo nodig met de vermelding e.a., en het jaartal van de publicatie. Alleen in de tabellen van hoofdstuk 1 is daarop een uitzondering gemaakt omwille van de lay-out. Het is onze hoop dat de lezer zo vlot zinn weg vindt in de serie gratere en kleinere studies, die samen dit proefschrift wormen. 


\section{INLEIDING}

Toen vijftig jaar geleden de techniek van de cervixcytologie ontwikkeld werd, was het cervixcarcinoom een frequente aandoening die jaarlijks vele vrouwen het leven kostte (Papanicolaou 1943).

Sinds het op grote schaal uitvoeren van cervixuitstrijkjes is de incidentie van en meer nog de mortaliteit door invasieve cervixcarcinomen zeer drastisch afgenomen. Desondank is cervixcytologie als methode tot vroegdiagnostiek van (voorstadia van) het cervixcarcinoom niet onomstreden.

In de reeks handelingen die leiden tot een betrouwbare secundaire preventie van het cervixcarcinoom zijn er verschilliende zwakke schakels, zoals de selectie en de motivatie van de te onderzoeken vrouwen, de kwaliteit van de afnametechniek, de inter-observer variatie bij zowel de cytologische als de histologische beoordeling, een snelle en relevante rapportage en een gepaste follow-up. Dit proefschrift richt zich met name op de afnamekwaliteit van cervixuitstrijkjes.

Cervixscreening is een veel bestudeerd onderwerp. Zo is er een uitgebreide epidemiologische literatuur voorhanden over het effect van screening op de incidentie van en de mortaliteit door cervixcarcinomen.

Ook verschillende aspekten van de afnamekwaliteit waren in het verleden reeds onderwerp van onderzoek. Veel is echter nog onbekend. Als gevolg van het feit dat uitstrijkjes in eerste instantie werden afgenomen ter hoogte van de vaginakoepel, en later ter hoogte van de ectocervix, spitste de kwaliteitsdiscussile zich toe op de aanwezigheid van endocervicale cellen. Zo is nauwelijks onderzoek verricht naar het belang van de aanwezigheid van plaveiselicellen in het uitstrijkje of naar de gevolgen van onvoldoende of late fixatie. Weliswaar zijn er onderzoeksresultaten beschikbaar over het verband tussen de aanvezigheid van endocervicale cellen in een uitstrijkje en de kans op het vinden van pathologie. Daarbij werd tot dusver echter nooit gecorrigeerd voor de invloed van een alantal voor de hand liggende covariabelen, zoals de afnametechniek of de uitstrijkervaring van de uitstrijkende arts. Over de invloed van andere kwaliteitskenmerken op de detectie van pathologie en op het uiteindelijk effect van screening is nauwelijks onderzoek verricht. Veel is gepubliceerd over verschillen tussen uitstrijkjes gemaakt met verschillende afnameinstrumenten. Toch blijven er, welke techniek er ook gebruikt wordt, verschillen tussen artsen bestaan. Vrijwel niets is uit onderzoek bekend over het effect van methoden om het handelen van artsen met betrekking tot de afnamekwaliteit te beinvloeden. In een Vlaamse setting is daarenboven niets bekend over het verband tussen algemene kenmerken van artsen of de door hen gebruikte technieken enerzijds en de kwaliteit van de door hen geproduceerde uitstrijkjes anderzijds. Kennis hierover is van belang teneinde eventuele interventies te kunnen richten op de meest relevante doelgroepen.

Dit proefschrift bestaat uit drie delen. In een eerste deel wordt door middel van een literatuurstudie de bestaande kennis rond determinanten van de afnamekwali- 
teit van cervixuitstrijkjes beschreven. Nadrukkelijk wordt hierbij aandacht besteed aan de invloed van de ainametechniek.

Het tweede deel beschrijft onderzoek naar elementen die een rol kunnen spelen bij de verbetering van de afnamekwaliteit.

Om het effect van feedback op de afnamekwaliteit van cervixuitstrijkjes te kunnen onderzoeken moest de onderzoekspopulatie in kaart gebracht worden. Beschrijvend onderzoek werd daarom verricht naar afnamegewoonten en ervaringen van een groep Vlaamse artsen, en naar het verband tussen artskenmerken en afnametechnieken enerzijds en de kwaliteit van de geproduceerde uitstrijkjes anderzijds. Daarnaast werd het verband nagegaan tussen een aantal indicatoren voor de afnamekwaliteit van uitstrijkjes en de in deze uitstrijkjes gevonden pathologie. Er werd gecorrigeerd voor de invloed van de andere kwaliteitsindicatoren; voor de leeftijd van de patienten en voor de invloed van de screenende laboratoriumas: sistenten. De invloed van dit alles op het uiteindelijk screeningseffect viel buiten het bestek van dit onderzoek.

Via een gerandomiseerd en gecontroleerd interventieonderzoek werd het effect nagegaan van verschillende vormen van feed-back op de afnamekwaliteit van cervixultstrijkjes. Daarbij werden voor het eerst onderzoeksgegevens verkregen over het effect van gedragsbeinvloedende interventies op dit terrein. Het is éen van de eerste gerandomiseerde interventiestudies naar het effect van feed-back, waarbij niet het aantal verrichtingen, maar de kwaliteit van de verrichtingen als outcome-maat gebruikt wordt.

In deel drie van dit proefschrift wordt tenslotte de rol van plaveiselcellen in de kwaliteitsbeoordeling van cervixuitstrijkjes bestudeerd: Daarbij wordt ook aandacht besteed aan de invloed die hierop uitgeoefend wordt door een eventueel aanwezige erythroplakie.

Vrijwel iedereen is thet eens over het belang van een goede kwaliteit in de verschillende stadia van de verwerking van cervixuitstrijkjes. De verschillende procedures rond de afname vormen daarbij het stadium van zorg waarvoor clinici de ver. antwoordelijkheid dragen. Ondanks de inmiddels respectabele ouderdom van de methode en ondanks het grote aantal uitstrijkjes dat tijdens de voorbije vijftig jaar geproduceerd werd, blijkt een goede afnamekwaliteit nog steeds geen algemene verworvenheid. Nu zowel in Vlaanderen als in Nederland de rol van huisartsen in de cervixscreening steeds belangrijker wordt, wil dit proefschrift bijdragen aan de invulling van hlaten in de bestaande kennis, waarbij vooral aan de evaluatie van feed-back belangrijke aandacht werd besteed. 


\section{DEEL I}

\section{LITERATUURSTUDIE}




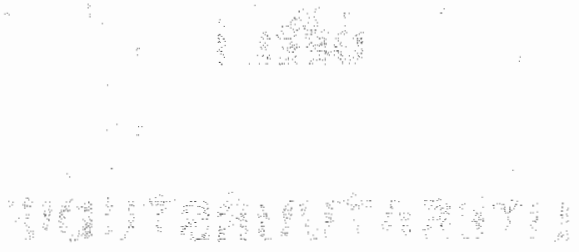




\section{HOOFDSTUK 1 \\ OP ZOEK NAAR UITSTRIJKJES VAN GOEDE KWALITEIT}

Een literatuurstudie

Via een meta-analyse van de literatuur werd de waarde van een aantal gebruikte indicatoren voor de afnamek waliteit van cervixuitstrijkjes onderzocht. Tevens werd de invloed van verschillende factoren op deze $k$ waliteitsindicatoren en op het voorkomen van pathologische cellen in een uitstrijkje bestudeerd.

Gezien de witgebreidheid van dit hoofdstuk is op de volgende bladzijden een gedetailleerde inhoudsopgave opgenomen.

De inhoud van dit hoofdstuk is een bewerkte versie van:

* Buntinx F., Knottnerus J.A., Crebolder H.F.J.M., Essed G.G.M. Iri search of good quality cervical smears - a literature review. Bijlage bij: Pas L. Concerted Action on General Practitioners involvement in cancer prevention. - General reviews. Report for the COMAC-MSR. Aanvaard voor publicatie. 


\section{INHOUD}

\section{INLEIDING}

\section{METHODE}

\section{RESULTATEN}

1. Definitie van afnamekwaliteit

1.1. Verband tussen het al dan niet voorkomen van endocervicale cellen en pathollogie

1.2. Verband tussen het al dan niet voorkomen van plaveiselcellen en pathologie

1.3. Verband tussen andere kwaliteitscriteria en pathologie

2. Invloed van diverse factoren op kwaliteitsindicatoren

2.1. Patiëntkenmerken

2.1.1. Leeftijd

2.1.2. Pariteit

2.1.3. Vroegere ingrepen aan de cervix

2.2. Invloed van de ornstandigheden

2.2.1. Bloedverlies

2.2.2. Tijdstip in de menstruele cyclus

2.2.3. Ontsteking

2.2.4. Zwangerschap

2.2.5. Anticonceptiegebruik

2.2.6. Klachten en symptomen

2.3. Intravaginale manipulaties

2.4. Een tweede uitstrijkje

3. Invloed van het afnamemateriaal

3.1. Verband tussen afnametechniek en pathologie

3.1.1. Gepaarde uitstrijkjes

- Wattenstok / Ayre Spatel

- Spatel + Cytobrush / Spatel

- Spatel / Multispatula

3.1.2. Vergelijkingen tussen groepen van verschillende patiënten

- Spatel + Cytobrush / Spatel alleen

- Spatel + Cytobrush / Cervex

- Extended-tip Spatel / Ayre Spatel

- Cytobrush / Wattenstok

- Cytobrush / Extended-tip Spatel

- Cervex/Extended-tip Spatel

- Spatel + Watteristok / Ayre Spatel

- Cytopick

- Afnametechniek volgens het uitzicht van de portio 
3.1.3. In vitro proeven

3.1.4. Samenvatting van de resultaten

3.2. Verband tussen afnametechniek en het vinden van endocervicale cellen

3.2.1. Gepaarde uitstrijkjes

- Wattenstok/Cytobrush

- Ayre Spatel / Multispatula

- Ayre Spatel/ Cytobrush

- Ayre Spatel / Extended-tip Spatel

- Ayre Spatel/Wattenstok

- Accu-Pap / Extended-tip Spatel

3.2.2. Vergelijkingen tussen groepen van verschillende patiënten

- Ayre Spatel / Extended-tip Spatel

- Spatel + Wattenstok / Extended-tip Spatel

- Spatel / Spatel + Cytobrush

- Extended-tip Spatel / Cervex

- Spatel + Wattenstok / Cervex

- Ayre Spatel / Multispatula

- Wattenstok / Cytobrush

- Spatel + Bulb aspirator / Spatel + Cytobrush

- Cervex / Spatel + Cytobrush

- Cytopick/Spatel + Cytobrush

- Cervex / Cytopick

- Andere

3.2.3. Pick-up rates

3.2.4. Samenvatting van de resultaten

3.3. Plaveiselcellen

3.3.1. Gepaarde uitstrijkjes

3.3.2. Vergelijkingen tussen groepen van verschillende petiënten

3.4. Onkosten bij verschillende afnamemethoden

3.5. Samenvatting

4. Invloed van de afstrijktechniek

5. Invloed van de fixatietechniek

6. Invloed van de uitstrijk(st)er

6.1. Discipline

6.2. Ervaring

6.3. Individuele factoren

7. Opleiding en feed-back

\section{BESLUIT}




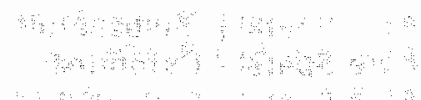

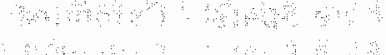

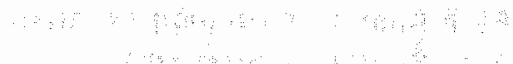

$\therefore \quad \therefore \quad \therefore \quad \therefore$ 


\section{INLEIDING}

Vijftig jaar na de eerste publicatie van Papanicolaou en Traut (Papanicolaou e.a. 1941 ) is cervixscreening nog steeds onderverp van een voortdurende discussie. De waarde van cervixuitstrijkjes voor de secundaire preventie van het cervixcarcinoom wordt beînvloed door verschillende factoren (Buntinx e.a, 1989 , Greening 1985, Koss 1989, Koss e.a. 1974. Pas 1991. Richart 1979, Steiner 1989, Zuna 19841. Uiteraard is het van primair belang dat de risicopopulatie ook effectief bereikt wordt. Daarnaast zijn echter een kwalitatief goede afname, een correct cytologisch onderzoek, een snelle en relevante rapportage en een gepaste follow-up essentiele vereisten. Samen vormen zij een keten, waarvan de zwakste schakel de sterkte bepaalt.

Er zijn heel wat aanwijzingen dat de afnamekwaliteit van de uitstrijkjes éen van de zwakkere schakels zou żijn (Evans 1989, Van der Graaf e.a. 1986, Mitchell e.a. 1990 ). Alleszins blijken telkens weer grote kwaliteitsverschillen tussen artsen op te treden.

Veel auteurs hebben in de loop der jaren op allerlei wijzen geprobeerd de verschil. lende aspecten van dit probleem te analyseren. Het is de bedoeling van deze studie hun ervaringen te bundelen en waar mogelijk besluiten te formuleren, die later vertaald kunnen worden in richtlijnen voor de uitstrijkende artsen.

\section{METHODE}

Op 10 januari 1989 werd via de terminal van het Limburgs Universitair Centrum te Diepenbeek een on-line search verricht via DIALOG.

Er werd gezocht in het volledige MEDLINE bestand, dat on-line beschikbaar is sinds 1966. Daarbij werden volgende MESH sleutelwoorden gebruikt:

* vaginall)smear? and method? or instrument?

- cervixlneoplasm? and diagnos? and

- evaluat?(/stud?

- predict?

- sensitiv?

Daarnaast werden alle referenties opgevraagd van vier auteurs van wie, op grond van reeds bekende publicatles, een belangrijke bijdrage verwacht werd. Het betrof Boon, Papanicolaou, Rublo en Vooijs.

De on-line search werd tot einde $1990 \mathrm{om}$ de drie maanden bijgewerkt via een search op de CD-ROM van de Bibliotheek van het Academisch Ziekenhuis Maastricht. Daarbij werden telkens overeenkomende sleutelwoorden gebruikt.

Op analoge wijze werd FAMLI geraadpleegd, een specifiek huisartsgeneeskundig indexsysteem, in boekvorm beschikbaar sinds 1980 en op diskette voor 1989.

De op deze wijze verzamelde referenties werden op hun pruikbaarheid gescreend op basis van de meegeleverde abstracts.

De geselecteerde artikelen werden opgevraagd. waarbij de verschillende literatuurlijsten op hun beurt goed waren woor een nieuwe oogst wa een proces, dat doof Verhellen en Vander Stichele alls "sneeuwballen" beschreven werd Verhellen e.a. 1986). Hierdoor, en via in de loop der jaren opgebouwde persoonlijke contacten, 
bereikten wij ook (een deel van?l de veelal grijze literatuur van rapporten, verslagen en proefschriften. Er werden geen (nog) niet gepubliceerde gegevens in dit overzicht betrokken.

op deze wijze werd een verzameling aangelegd van ruim 300 artikelen over cervixcytologie. Wij selecteerden daaruit de artikelen die, meestal originele, informatie bevatten over de gestelde vragen. Voor tabellen en vergellijkingen werd alleen gebruik gemaakt van oorspronkelijke researchrapporten. In eerste instantie werden daarbij geen kwaliteitseriteria aangelegd met betrekking tot de gebruikte onderzoeksmethode. Bij verschillende onderdelen van dit rapport werd wel onderscheid gemaakt naar de gebrulkte methode. Dan wordt zulks expliciet aangegeven. Sommige onderzoeken op dit terrein duren vele jaren. Naarmate het aantal onderzochte uitstrijkjes stijgt, stijgt ook de overtuigingskracht van het onderzoek. In deze gevallen worden er regelmatig rapporten gepubliceerd op basis van gegevens; die enkele jaren later opnieuw opduiken in het verslag over een langere tijdspanne. I bijvoorbeeld Boon 1985, Boon e.a. 1986 en Elias e.a. 1983, Vooijs e.a. 1986, Vooils e.a. 1987). In dergelijke gevallen is als regel het meest recente rapport gebruikt.

Voor dit overzicht stelden wij ons de volgende vragen:

1. Hoe wordt het begrip afnamekwaliteit van cervixuitstrijkjes gedefinieerd? Is er een verband tussen het al dan niet voorkomen van endocervicale cellen of plaveiselcellen in het uitstrijkje en het vinden van pathologie?

II. Wat is de invloed van patiëntkenmerken en klinische omstandigheden op verschillende $\mathrm{k}$ waliteitsindicatoren in een uitstrijkje?

III. In hoeverre is er verband tussen de afnamekwaliteit en het gebruikte afnamemateriaal?

IV. Wat is de invloed van de afstrijktechniek op het aantal en de verdeling van de gevonden cellen?

V. In hoeverre is er verband tussen de afnamekwaliteit en de fixatietechniek?

VI. In hoeverre is er verband tussen de afnamekwaliteit en kenmerken van de witstrijk(st)er?

VII. Wat is er bekend over de invloed van feed-back en opleidingsmethoden op de afnamekwaliteit van cervixuitstrijkjes?

Er werd nagegaan in hoeverre de literatuur een antwoord kan bieden op onze onderzoeksuragen. Vrijwel steeds was het mogelijk zich daarbij te beperken tot originele onderzoeksrapporten. De alldus werzamelde resultaten werden samengevat en kritisch becommentarieerd, zoals $0 . \mathrm{m}$. door Light aanbevolen (Light 1984).

Voor alle gerapporteerde outcome-waarden werden zoveel mogelijk de $95 \%$ betrouwbaarheids intervallen $(95 \% \mathrm{BH}$ ) vermeld. Als zij niet vermeld zijn door de oorspronkelijke auteur, hebben wij hen, op basis vam de gepubliceerde gegevens, zelf berekend. Daarbij werden technieken gebruikt, zoals beschreven door Gardner en Altman (Gardner e.a. 1986, Gardner e.a. 1989).

Wanneer verschillende studies op een vergelijkbare wijze dezelfde vraagstelling behandelen, hebben wij de verschillende resultaten onderling vergeleken (Bulpitt 1988, Ter Riet e.a. 1989). Als voormaamste basis voor de vergelijking gebruikten 
wij daarbij in navolging van Collins e. a het Relatief Risico met zijm $95 \%$ betrouwbaarheids interval (Collins e.a. 1985, Laupacis 1988). Waar nodig werd dat door ons berekend volgens de techniek, beschreven door Marris en Gardner Morris e.a. 1988). Soms is echter ook gebruik gemaakt van de sensitiviteit, van prevalentieof incidentiecijfers of van een correlatiecoèfficiênt.

In een groot aantall gevallen werd tevens een gepoolde ratio berekend. Daarbij wordt een gewogen gemiddelde gemaakt van de resultaten van een aantal studies, die allen op dezelfde wijze opgebouwd zijn. Een op deze wijze gepoolde ratio geeft als het ware een totaalbeeld van alle verrichte onderzoeken. In de meeste gevallen werd hiervoor een gepoolde odds ratio gebruikt als benadering van het relatief risico. Alleen wanneer een hoge prevalentie van het te onderzoeken kenmerk dit nodig maakte werd een gepoold relatief risico (met de hand) berekend, Voor deze berekeningen werd gebruik gemaakt van Mantel-Haenszel schattingen, zoals beschreven door Rothman voor gestratificeerde analyse (Rothman 1986). Wij konden daarbij beschikken over Confidence Interval Analysis, een softwareprogramma, verspreid door de uitgever van de British Medical Journal (Gardner e.a. 1989). Een meer uitvoerige bespreking van de hier gebruikte methoden is opgenomen in hoofdstuk 3.

Bij alle vergelijkingen, die in dit overzicht ter sprake komen, dient rekening gehouden te worden met drie beperkingen:

1. Uit alle hierover verrichte studies komt een zeer belangrijke intra- en interbeoordelaar variatie naar voren. Dit werd bij herhaling gevonden, zowel bij cytologische laboratoriumassistenten als bif pathologen (Allingham 1985, Glenthoj 1986, Klinkhamer 1989. Naujoks 1990, Vet de e.a. 1990) en is niet noodzakelijk gecorreleerd met het aantal jaren ervaring van de onderzoeker (Klinkhamer 1989). Het geldt zowel voor het scoren van kwaliteitskenmerken (Klinkhamer 1989), als voor het vinden van pathologie (Hicklin e.a. 1984, Klinkhamer e.a. 1989, Naujoks e.a. 1990, Vet de e.a. 1990l. In studies met een klein aantal uitstrijkjes worden alle cytologische onderzoeken daarom vaak door eenzelfde persoon verricht. Bij een studie van enige omvang is het echter moeilijk hiervoor te controleren.

2. Bij vergelijkingen waarbij twee afnames noodzakelijk zijn, kan de volgorde van de afnames van invloed zijn op het resultaat. Sommige onderzoekers lossen dit op door de volgorde telkens te veranderen. Anderen plaatsen de techniek waarvan het meest gunstige effect verwacht wordt, in de volgens hen meest nadelige positie. Voorlopig bestaat er over de invloed van de volgorde echter geen volledige duidelijkheid (Brock 1986, Luthy e.a. 1987. Stock a.a. 1988. Trimbos e.a. 1986) en blijft dit een probleem.

3. Bij vergelijkingen tussen twee verschillende technieken of omstandigheden, kunnen de resultaten door tal van confounders vertekend worden. Hiervoor wordt in de door ons verzamelde studies zelden of nooit gecontroleerd. 


\section{RESULTATEN}

\section{Definitie van afnamekwaliteit}

Vifftig jaar na de eerste publicaties (Papanicolaou e.a. 1941) over de Pap-simear, bestaat er een levendige discussie over de preclese rol van cervixcytologie in de preventie van het cervixcarcinoom. Er bestaat zelfs geen algemene overeenstemming over de criteria, waaraan een uitstrijkje minimaal dient te voldoen.

Gelukkig zin de meeste auteurs het wel eens over de kenmerken van een deaal utstrikje, Een dergelijk uitstrikje moet afgenomen ziln onder direct zicht op de cervix (Greening 1985 , Koss 1989, Koss e.a. 1974), ter hoogte van de overgangszone tussen plaveiselepitheel en endocervicaal epitheel. Dit moet blijken uit de aanwezigheid van plaveiselcellen, zowel als endocervicale cellen (Anoniem 1980 , Greening 1985, Koss 1989, Koss e.a. 1974). Er moet een voldoende groot aantal cellen te zlen ziln (Greening 1985, Neinstein e.a. 1989). Bij voorkeur bevinden zich geen bloed (Greening 1985 ) en geen ontstekingscellen (Greening 1985) in het uitstrijkje. De cellen moeten goed geconserveerd zljn, wat een snelle en correcte fixatie veronderstelt (Greening 1985, Koss 1989, Koss e.a. 1974, Papanicolaou e.a. 1941\%. Uiteraard is het vinden van pathologie een belangrijk, zij het gelukkig niet noodzakelijk argument dat een uitstrijkje goed afgenomen is. Overigens kunnen losgeraakte pathologische cellen ook elders gevonden worden en betekent het vinden van afwijkende cellen niet steeds dat net nog ernstiger pathologie gemist wordt.

Er bestaat overeenstemming over het feit dat cervixcarcinomen zich in eerste instantie ontwikkelen ter hoogte van de overgangszone 'Transformation zone. Squamocolumnar junction' (Greening 1985, Vooijs 1988). Deze overgangszone bevindt zich bij jonge meisjes ter hoogte van het ostium externum en verplaatst zich na het bereiken van de geslacthtsrijpe leeftijd vaak naar een meer perifere positie op de portio. Na de menopause daarentegen trekt zij zich terug binnen in de baarmoederhals. De positie wordt ook beinvloed door veranderingen in de hormonale status van de vrouw zoals bij het gebruik van hormonale anticonceptie of zwangerschap (Greening 1985 ).

Als gevolg van het feit dat uitstrikjes in eerste instantie werden afgenomen ter hoogte van de vaginakoepel, en later ter hoogte van de ectocervix, spitste de kwaliteitsdiscussie zich toe op de anwezigheid van endocervicale cellen. Men kan zich afwragen in hoeverre dit terecht is. Immers ook andere indicatoren als de aanwezlgheid van plaveiselcellen en de kwaliteit van de fixatie blijken een belang rijke rol te spelen. Toch blijft de a anwezigheid van endocervicale len/of metaplastischel cellen een belangrijk criterium. Dit werd bevestigd en versterkt toen een aantal auteurs (Elias e.a. 1983, Killough e.a. 1988, Vooils 1988, Vooijs e.a. 1986) vaker pathologie vonden en minder kans op vals negatieve resultaten bij aanwezigheid van endocervicale cellen. Er zijn echter ook auteurs die weinig of geen verschil in pathologiedetectie vanden tussen uitstrijkjes met en zonder endocervicale cellen (Kivlahan 1986). Zij wijzen er ook op dat niet alleen vaak pathologie gevonden wordt in afwezigheid van endocervicale cellen (Koss e.a. 1974, Wolfen- 
dale e.a. 1987), maar dat utstrijkjes vals negatief kunnen zijh ondanks de aanwezigheid ervan IKoss e.a. 1974, Spurette.a. 1989, Wolfendale 1987 ).

De meeste auteurs die de aanwezigheid van endocervicale cellen noodzakelik vinden, beschouwen ook de aamwezigheid vam metaplastische cellen als een voldoende bewijs van een correcte localisatie van de afname, ook als er verder geen endocervicale cellen gevanden worden.

Eigenaardig hierbij is dat dergelijke discussies nauwelijks gevoerd worden over de noodzaak van plaveiselcellen. Slechts enkele auteurs hebben hier aandacht voor (Anoniem 1989, Buntinx e.a. 1984, Buntinx e.a. 1991, Doornewaard e.a. 1990; Greening 1985, Spurret e.a. 1989). Wellicht heeft dat te maken met het feit dat het frekwent ontbreken wan endocervicale cellen in uitstrijkjes het eerst gesignaleerd werd en dat het belang ervan groter lijkt dan het belang van het ontbreken van plaveisellcellen.

\section{Vals negatieve uitstrijkjes}

In een review van 13 studies die de oorzaak onderzochten van vals negatieve uitstrijkjes werd een "True false negative rate" gevonden van $55 \%$ (Evans 1989 ). Onder deze term verstaat de auteur het percentage vals negatieve uitstrijkjes lop basis van histologische gegevens) dat bij herzien opnieuw beoordeeld wordt als negatief en van goede kwaliteit. $36 \%$ van de 373 in deze review verwerkte uitstrijkjes werden bij herbeoordeling als positief beschreven en $9 \%$ waren van onvoldoende kwalliteit.

Van der Graaf ea. herbeoordeelden 555 negatief beoordeelde uitstrijkjes van vrouwen die in de loop van de drie volgende jaren pathologie (matige dysplasie of meer) ontwikkelden (van der Graaf e.a. 1986). Zij beoordeelden in deze groep $70 \%$ van de uitstrijkjes opnieuw als negatief waarbij in $12.3 \%$ van de gevallen de afnamekwaliteit anvoldoende geacht werd.

Door Mitchell, Medley en Giles werden in een periode van 5 jaar 1.044 gevallen van cervixcarcinoam gevonden. In $13.2 \%$ was er sprake van interval kankers bil vrouwen met tenminste 1 uitstrijkje binnen de voorafgaande 3 jaar. Hiervan werd bij herbeoordeling van de preparaten slechts $11,9 \%$ lof $1.6 \%$ van de oorspronkelijke 1.044 gevallen van cervixcarcinoam) opnieuw beschreven als negatief bij een goede afnamekwaliteit, hier gedefinieerd als een uitstrijkje dat endocervicale en/of metaplastische cellen bevatte (Mitchell e.a. 1990).

\section{Vals positieve uitstrijkjes}

Er dient hier ook gewezen te worden op de mogelikheid van een relatie tussen kwaliteitsindicatoren en het voorkomen van vals positieve resultaten. Op deze mogelijkheid wordt teruggekomen bij de bespreking van de verschillende indica. toren.

\subsection{Verband tussen het al dan niet voorkomen van Endocervicale cellen en Pathologie}

Vrij algemeen wordt het al dan niet woorkomen van endocervicale len metaplastischel cellen beschouwd als een belangrijke indicator voor de afnamekwaliteit van een cervixuitstrijkje. Toch is ook over de waarde hiervan de discussie nog niet gesloten. Uiteindelijk zal moeten worden nagegaan of bij de groep vrouwen met een uitstrijkje met endocervicale cellen een eventueel optredend cervixcarcinoom 
vroeger ontdekt wordt, en of de hiermee samenhangende morbiditeit en mortaliteit uiteindelijk geringer zijn dan bij een vergeljikbare groep vrouwen met een uitstrijkje zonder endocervicale cellen Ruffin 1988). Pas dan zal tot ieders tevredenheld de noodzaak aangetoond zijn van endocervicale cellen in het uitstrijkje.

Voorlopig bestaat en dergelijke studie (nog) niet. Wij moeten ons dus behelpen met gedeeltelijke gegevens.

1. Wij verzamelden een aantall studies waarbij voor én afname-instrument het percentage pathologie vergeleken wordt in uitstrijkjes met en zonder endocervicale cellen (tabel 1, 1, In al deze studies werd gewerkt meteen homogene groep uitstrijk(st)ers en bij patienten zonder (aangegeven) grote verschillen in leeftijd. Hieronder waren dus geen vergelijkende studies tussen verschillende afnameinstrumenten. Voor de studie van Vooijs e.a. werden de meest recente data (Vooijs 1988) gebruikt. Tussentijose rapportages over lagere aantallen uit deze studie werden eerder gepubliceerd (Elias e.a. 1983, Vooijs e.e. 1985).

Waar dit niet reeds door de auteur gedaan was, berekenden will zelf het relatief fisico als de verhouding tussen de percentages afwijkende uitstrijkjes in uitstrijkjes met en zonder endocervicale cellen.

In alle gevallen was er een duidelijk positief verband tussen de aanwezigheid van endocervicale cellen en het percentage cytologische afwijkende uitstrijkjes.

Tabell 1.1: Relatief risico voor het vinden van pathologie bij aan-versus afwezig zijn van endocervicale cellen in het uitstrijkje

\begin{tabular}{|c|c|c|c|c|}
\hline Refierentio & Criterium patholagle & Fielatiof risico & $95 \% \mathrm{BI}$ & $\begin{array}{l}\text { Totabl abntal uit } \\
\text { strijkjes: }\end{array}$ \\
\hline 123 & atypia & 4.09 & $3.63-4.60$ & 43677 \\
\hline 223 & $\geq$ lichte dysplasio & 274 & $1.81-4.14$ & 93264 \\
\hline 151 & $\geq$ CIN I & 2.89 & $2.38=3.59$ & 21222 \\
\hline 144 & $\geq \operatorname{CIN} !$ & 2.24 & $1.81-2.77$ & 32801 \\
\hline 223 & zernetige dysplasio & 4.27 & $1.77 \cdot 10.30$ & 93264 \\
\hline 140 & $\geq C_{n} 1 . \bar{S}$ & 2.35 & . & 40000 \\
\hline
\end{tabular}

De resultaten van de twee studies die CIN I als afkappunt hebben werden gebundeld: $O R_{\mathrm{mh}}=2.61(95 \% \mathrm{Bl}=2.25-3.02)$.

In een recente Australische studie wordt enkel een Spearman's rank correlatiecoefficiënt van $0.379(p<0.001)$ gepubliceerd voor het verband tussen het percentage uitstrijkjes met endocervicale cellen en het percentage uitstrijkjes met atypie voor 179 artsen die in de loop van een jaar elk temminste 200 uitstrijkjes afnamen (Laverty e.a. 1989).

In een studie (Mauney e.a. 1990) werd er voor de leeftijd gecontroleerd: de RR's liggen in alle leeftijdsgroepen rond dezelfde waarden met uitzondering van de 
twee extreme leeftijdsgroepen (14-19 jaar en 70-85 jaar) waar de verschillen kleiner worden en statistisch ook niet meer significant zijn.

In twee studies vond ook een vergelijking plaats met histologische diagnosen. Eén auteur (Mauney e.a. 1990 ) vermeldt een $85 \%$ overeenkomst tussen de cytologi: sche en de histologische diagnose. In de tweede studie (Mitchell e.a. 1991 ) werd de analyse overgedaan met alleen de histologisch bevestigde diagnosen als eindpunt. Hierbij komen wij tot een RR $=4.03195 \% \mathrm{BI}=2.83-5.72)$. Het verschill is dus nog groter dan bij het gebruik van de cytologische diagnose als eindpunt ( $R R=2.89)$.

2. Twee auteurs gingen nog een stap verder. Zij gingen uit van de hypothese dat er minder pathologie gevonden zou worden indien in een vorig, als normaal beoordeeld uitstrijkje endocervicale cellen gevonden waren (tabel 1.24.

Ook hier gebruiken wij het relatief risico als vergelijkingsmaat. Ditmaal berekenen wij echter de verhouding tussen de percentages afwijkende uitstrijkjes in een tweede uitstrijkje bij patiënten, bij wie in een vorig uitstrijkje niet, respectievelijk wel endocervicale cellen gevonden werden.

Tabel 1.2: Relatief risico voor het vinden van pathologie in een tweede uitstrijkje bij niet versus wel voorkomen van endocervicalle cellen in het voorgaande uiltstrijkje

\begin{tabular}{|c|c|c|c|c|c|c|}
\hline Ref & $\begin{array}{l}\text { Criterium patho } \\
\text { logie }\end{array}$ & $\begin{array}{l}\text { Voorkonen van pathologie in } \\
\text { tweede uitstirijje } \\
\text { bij eerste uitstrijkje } \\
\text { Endo }\end{array}$ & $R$ & $\begin{array}{l}95 \% \mathrm{BI} \\
(\mathrm{RR}) \\
\vdots\end{array}$ & $\begin{array}{l}\text { Aantal } \\
\text { witsterijk- } \\
\text { jes }\end{array}$ & $\begin{array}{l}\text { Duwn } \\
\text { Folliow } \\
\text { up }\end{array}$ \\
\hline 127 & geringe dysplas le & $3.0^{*}$ & 0.91 & $0.68 \times 1.21$ & 5975 & $4 j$ \\
\hline 223 & geringe dysplasie & $0.80^{k}$ & 0.76 & $0.50-1.17$ & 42971 & $3 j=$ \\
\hline 151 & $C M \geq 1$ & $13.93^{\text {kit }}$ & 0.74 & $0.69-0.79$ & 20222 & $2 j$ \\
\hline
\end{tabular}

$\mathrm{QR}_{\mathrm{rth}}=0.83(0.76-0.90)$.

* Prevalenties (\%)

w Woor leeftujd gestandaardiseerde incidenties (per 1000 partent-jaren follow-up).

In de twee eerste studies werd geen rekening gehouden met het al dan niet vinden van endocervicale cellen in het tweede uitstrijkje. In de derde studie gebeurde daze opsplitsing wel. Als daarbij enkel rekening gehouden wordt met vrouwen waarvan het tweede uitstrijkje endocervicale cellen bevatte, krijgen wij echter een vergelijkbaar resultaat: $R R=0.86(0.80-0.93)$ in plaats van 0.74 .

Deze gegevens pleiten voor de stelling dat in uitstrijkjes zonder endocervicale cellen hetzij weinig afwijkingen gemist worden (weinig waarschijnlijk gezien de gegevens uit paragraaf 1.1.1), hetzij alleen pathologie gemist wordt die toch grotendeels wit zichzelf regredieert.

Kivlahan en Ingram vergeleken groepen patiënten met een derde, respectievelijk vierde uitstrijkje na twee, respectievelijk drie voorgaande normale uitstrijkjes met 
of zonder endocervicale cellen. Daarbij weiden geen significante verschillen gevoriden (Kiwlahan e.a. 1986).

Nog een stap verder gaat een studie met een opmerkelijk onderzoeksdesign waarbij 20 patienten geselecteerd werden die in de loop van 18 maanden elk drie uitstrijkjes kregen, walarvan het eerste en laatste pathologile aantoonde; terwill het tweede negatief was (Woodmain e.a. 1989). Bij iedere vrouw werd daarenboven na het laatste uitstrijkje een gerichte biopsie verricht, die bij histologisch onderzoek een CIN $\geq$ I opleverde. Dit duidt er volgens de auteurs op dat het tweede uitstrijkje vals negatief was. Dit uitstrijkje werd vergeleken met de beide positieve uitstrijkjes in een case-control studie. Uit de vergelijking blikt een positief, maar niet significant verband tussen de afwezigheid van endocervicale cellen en de kans op een vals negatief uitstrijkje $(\mathrm{RP}=2.44 ; 95 \% \mathrm{Bl}=0.67-9.09)$. Er is een sterk en significant verband tussen dekans op een vals negatief uitstrijkje en de afwezigheid van metaplastische cellen, $(R R=25.0 ; 95 \% \mathrm{BI}=4.76-100.0)$ respectievelijk de afwezigheid van endocervicale of metaplastische cellen $(R R=20.0 ; 95 \% \mathrm{Bl}=3.85-100.0)$.

3. Door Boonen de Graiaf Guilloud-Gentenaar werd bij vier zeer ervaren uitstrijksters een vrijwel gelijk $10.23=0.24 \%)$ percentage positieve vitstrijken gevonden bij een percentage uitstrijkjes met endocervicale cellen dat varieert tussen 82 en $91 \%$. De correlatie coëfficlent bedraagt: -0.26 (Boon e. $a .1986 \mathrm{c}$ ). Uit een andere studie (Vooijs e.a. 1986) kan voor vijf ervaren uitstrijksters met dezelfde vraagstelling een correlatie- coëfficient van 0:05 berekend worden. Üt geen van beide studies kan voor deze groepen van uitstrijksters een duidelijk verband afgeleid worden tussen hun oogst aan endocervicale cellen en hun oogst aan pathologische uitstrijkjes.

4. Detweiler e.a. vonden bij de evaluatie van 43 vals negatieve uitstrijkjes in 17 $(40 \%)$ uitstrijkjes wel en in $26(60 \%)$ geen endocervicale cellen (Detweiler e.a. 1989). Bij de vals negatieve uitstrijkjes met endocervicalle cellen waren er 9 met een uitgebreid letsel. Ook elders (Boon e.a. 1986) wordt gesignaleerd dat in een aantal gevallen pathologie gevonden wordt in herhalingsuitstrijkjes na vorige uitstrijkjes die als normaal beoordeeld waren, maar geen endocervicale cellen bevatten. Zij vermelden hierbij echter geen aantallen.

Mitchell \& Medly volgden gedurende 2 jaar ruim 20.000 wrouwen en vergeleken het optreden van afwijkingen bij een volgend uitstrijkje. Zij vonden geen stijging van het aantal afwijkingen bij vrouwen wier eerste witstrijkjes geen endocervicale cellen toonde, wat leidde tot het besluit dat er geen reden is voor het vervroegd heruitstrijken na een uitstrijkje zonder endocervicale cellen (Mitchell e.a. 1991).

5. Reeds in 1970 werd beschreven dat de meerderheid van de lichte dysplasieên op de actocervix gelokaliseerd is (Burghardt 1970). De ernstiger afwijkingen dabrentegen liggen vaker in het endocervicaal kanaal. Daaruit wordt afgeleid dat het wellicht vooral de ernstiger afwijkingen zijn, die gemist worden als de overgangszone bil het uitstrijken niet geraakt wordt (Boon e.a. 1985).

Recenter vergeleken Hadjimichael e.a. de histologische gegevens van 31 gevallen van "Rapidly progressive cervical cancer" met 166 andere gevallen van invasief cervixcarcinoom. Zij vonden in de eerste groep $35 \%$ adenocarcinomata tegen $11 \%$ in de tweede groep $10 \mathrm{R}=4.52 ; 95 \% \mathrm{Bl}=1.70-11.14 ; \mathrm{p}=0.001$ Fisher's Exact $\mathrm{l}$. Dit type tumor ontwikkelt zich vanuit de endocervix en schilfert minder goed af dan 
andere carcinomen. De auteurs suggereren op basis hiervan dat het vooral voor de detectie van deze snelgroeiende tumoren belangrijk is zo effectief mogelijke, op de endocervix gerichte, afnameapparaatjes te gebruiken (Hadjimichael e a. 1989).

6. Vrijwel alle auteurs die de aanwezigheid van endocervicale cellen beoordelen; gebruiken de aan- of afwezigheid van deze cellen als hun afkappunt. Recent werd gesuggereerd om uitstrijkjes slechts als representatief te beschouwen als er tenminste 25 endocervicale cellen gevonden worden (Dotters e.a. 1988). Deze grens is arbitrair gekozen. Aangezien de aanwezigheid van endocervicale cellen niet zozeer op zichzelf belangrijk is, maar aannemelijk maakt dat de overgangszone bij het uitstrijken geraakt werd, lijkt het ons niet logisch welk aantal cellen dan ook als minimum te stellen.

1.2. Verband tussen het al dan niet voorkomen van plaveiselcellen en pathologie Er wordt vrij algemeen aangenomen dat een cervixuitstrijkje cellen moet bevatten van de overgangszone tussen endo-en ectocervicaal weefsel. Het ligt dan ook voor de hand om de aanwezigheid van zowel endocervicale als plaveiselcellen als een vereiste te stellen voor een representatief uitstrijkje en dus als eén van de vereisten voor goede afnamekwaliteit.

Er is weinig onderzoek verricht ter evaluatie van het belang van plaveiselcellen in cervixuitstriijkjes.

In een onderzoek bij 444 hoofdzakelijk pathologische uitstrijkjes werd een zeer sterke associatie gevonden tussen de afwezigheid van plaveiselcellen enerzijds en het voorkomen van vals negatieve Cytobrushuitstrijkjes (OR $=5.67 ; 95 \% \mathrm{BI}=$ $1.18-25.08$. $p=0.003$ - Fisher's Exact) (Zie hoofdstuk 10 van dit proefschrift). Als in deze uitstrijkjes alleen een Cytobrushafname verricht was, zou pathologie gemist zijn in $3 \%$ van de gevallen.

In een gellijksoortige studie werd gevonden dat 11/57 gevallen van CIN gemist zouden zijn als er enkel een Cytobrushuitstrijk gemaakt zou zijn in plaats van een combinatie-uitstrijk (Spurret e.a. 1989). In al deze gevallen bevond de transformatiezone zich ver van het ostium op de portio. De auteur stelt daarbij vast dat alleen endocervicale cellen uitgestreken werden en dat de ectocervicale zijde van de overgangszone niet geraakt werd.

\subsection{Verband tussen andere kwaliteitscriteria en pathologie}

Onvoldoende fixatie kan aanleiding geven tot cellulaire artefakten waarbij afwijkingen in het celbeeld gemaskeerd kunnen worden (Rubio 1981, Zuna 1984). Eigen ervaringen, waarover in hoofdstuk 6 gerapporteerd wordt, suggereren daarnaast dat door onvoldoende fixatie pathologie niet alleen gemaskeerd, maar ook geïmiteerd kan worden.

Elders werd een RR van 2.34 gevonden voor het gemiddeld aantal velden lop een totaal van 15 in elk uitstrijkje) dat als adekwaat beoordeeld werd op basis van een algemeen kwaliteitsoordeel gebaseerd op celrijkdom (cellularity), hinderende aanwezigheid van bloed of ontstekingscellen of slechte fixatie $(n=352)$ bij vergelijking van correct positieve met fout negatieve uitstrijkjes met het pathologisch biopsie resultaat binnen 3 maanden als gouden standaard (Valente e.a. 1990). 


\section{Invloed van diverse factoren op kwaliteitsindicatoren}

\subsection{Patiëntkenmerken}

\subsubsection{LEEFTIUD}

Als regel wordt in de literatuur vermeld dat de kans op het vinden van endocervicale cellen afneemt met de leeftifd. Dit wordt bevestigd door gegevens, gebaseerd op een totaal van 82210 uitstrijkjes bij vrouwen tussen 35 en 55 jaar, die dee Inamen aan het Nederlands bevolkingsonderzoek, Daarbij werd een systematische daling van het percentage uitstrijkjes met endocervicale cellen gevonden bij toenemende leeftijd (Vooijs e.a. 1985 ).

Het is daarom enigzins verrassend te lezen dat vrijwel alle andere onderzoekers weinig of geen verschil vinden, zij het bij veel kleinere aantallen uitstrijkjes (Kawaguchi e.a. 1987, Allingham e.a. 1985, Taylor e.a. 1987, Deckert e.a. 1988, Kristensen e.a. 1989).

Ook een pooling van de resultaten uit de twee studies waarvoor voldoende data bekend zijn (Kristensen e.a. 1989, Taylor e.a. 1987 ) levert een niet significant verschil op: het relatief risico op afwezigheid van endocervicale cellen bij oudere versus jongere mensen (er van uitgaande dat de gemiddelde menopauzeleeftijd rond 50 jaar ligt) bedraagt $1.27(95 \% \mathrm{Bl}=0.87-1.85)$. Uiteraard is het daarbij mogelijk dat de invloed van andere factoren, bijuoorbeeld de afnametechniek, zo sterk is dat de leeftijdsinvloed hierdoor gemaskeerd wordt.

Het percentage vrouwen ouder dan 56 jaar bij vrouwen met tenminste 2 opeenvolgende uitstrijkjes zonder endocervicale cellen $(n=1854$ ) werd vergeleken met een groep vrouwen waarbij in een vorig uitstrijkje wel endocervicale cellen gevonden worden $(n=35097)$. Het relatief risico was $2.29(95 \% \mathrm{Bl}=1.992 .64)$ (Doorne waard e.a. 1990 .

Tabel 1.3: : Invloed van de leeftijd op het vinden van endocervicalle cellen (RR voor afwezigheid van endocervicale cellen in oude versus jonge groepl

\begin{tabular}{|c|c|c|c|c|c|c|c|c|c|c|}
\hline Ref & $\begin{array}{l}\text { Letef- } \\
\text { tijods } \\
\text { grants }\end{array}$ & $\begin{array}{l}\text { Aarin } \\
\text { Jionge } \\
\text { groep }\end{array}$ & $\begin{array}{l}\text { tel } \\
\text { outede } \\
\text { giroup }\end{array}$ & $\begin{array}{l}\text { Endoc } \\
\text { ciell le } \\
\text { s. } \\
\text { Jange } \\
\text { groep }\end{array}$ & $\begin{array}{l}\text { fcale } \\
\text { finezig } \\
\text { oude } \\
\text { sroep }\end{array}$ & RR & $95 \% \mathrm{Bt}$ & $p$ & $\begin{array}{l}\text { Tech" } \\
\text { riek }\end{array}$ & Setting \\
\hline 134 & $50 j$. & 745 & 96 & 24.0 & $28: 1$ & 1.17 & $\begin{array}{l}0.23 \\
1.56\end{array}$ & 0.38 & $\begin{array}{l}\text { Sp } \\
\text { Cbr } \\
\text { en sp }+ \\
\text { Wat }\end{array}$ & $\begin{array}{l}\text { universite itsla- } \\
\text { boratoriun } \\
\text { cytollogie }\end{array}$ \\
\hline 207 & $\begin{array}{l}\text { meria } \\
\text { patuza }\end{array}$ & 764 & 180 & 6.4 & 8.3 & 1.30 & $\begin{array}{l}0.75 \\
2.26\end{array}$ & 0.35 & $\begin{array}{l}\mathrm{sp}+ \\
\mathrm{tbr} \\
\text { Nete } \mathrm{sp}+\end{array}$ & $\begin{array}{l}\text { universitatio } \\
\text { gynaecologisiche } \\
\text { dienst }\end{array}$ \\
\hline 225 & $50 \mathrm{j}$ & 62656 & 19554 & 11.8 & 17.2 & 1.47 & $\begin{array}{l}1.41 \\
1.52\end{array}$ & 0.001 & $=$ & $\begin{array}{l}\text { bevolkingsionder- } \\
\text { zoek } \\
35-55 \%\end{array}$ \\
\hline
\end{tabular}




\subsubsection{PARITEIT}

In een steekproef van 459 vrouwen werd geen verband gevonden tussen de pariteit en de oogst aan endocervicale cellen (Allingham e.a. 1985).

\subsubsection{VROEGERE INGREPEN AAN DE CERVIX}

Biil 1 (Bewtra 1989) tot $5 \%$ (Vooijs e.a. 1986 ) van de patiënten worden toch nog endocervicalle cellen gewonden in een uitstrijkje afgenomen na een totale hysterectomie. Van Bewtra is de hypothese afkomstig dat het hier zou gaan om veranderingen in de basale en parabasale cellen, die daardoor niet meer van endocervicale cellen kunnen onderscheiden worden (Bewtra 1989). Uit een analyse van 100 dergelijke uitstrijkjes werden acht verschillende mogelijke oorzaken voor het vinden van endocervical-like cellen (Roberson e.a. 1990 ) geformuleerd "van weefselveranderingen, via endometriose tot metastatisch weefsel.

Trimbos en Arentz vonden in 9 van de 12 gevallen endocervicale cellen na een conisatie en in 7 van de 7 gevallen na cryotherapie van de portio (Trimbos e.a. 1986). Deze auteurs vermelden ook een andere studie uit hun instituut, waarbij men na conisatie endocervicale cellen vond in $67 \%$ van de uitstrijkjes. De grote meerderheid van deze uitstrijkjes vertoonde metaplastische cellen. Volgens deze auteurs ontstaat hier wellicht een nieuwe overgangszone met dezelfde kenmerken als de oorspronkelijke.

Elders werden bij 76 vrouwen na radiotherapie in $84 \%$ endocervicalle cellen gevonden (Taylor e.a. 1987). Frierson e.a. beschrijven in deze situatie een typisch beeld met erg grote en onregelmatige kernen. Zij waarschuwen ervoor dat het zich niet bewust zijn van deze mogelijke veranderingen kan leiden tat vals positieve diagnosen van recidief in de follow-up van patienten na radiotherapie wegens cervixcarcinoom (Frierson e.a. 1989).

\subsection{Invloed van de omstandigheden}

\subsubsection{BLOEDVERLIES}

In richtlijnen voor het maken van uitstrijkjes wordt regelmatig gewaarschuwd voor bloedbijmenging. Wij vonden echter, behalve de hieronder vermelde gegevens over de invloed van de menstruele cyclus, geen onderzoeksgegevens, die dit staven. Gesprekken met pathologen en screensters leerden ons dat grote hoeveelheden bloed weliswaar het zicht verhinderen, maar dat geringe bloedbijmenging nauwelijks problemen geeft. Door Allingham en King werd bij 283 vrouwen zelfs een duidelijk positief verband gewonden tussen de aanwezigheid van bloed en het voorkomen van endocervicalle cellen in het uitstrijkje (Allingham e.a. 1985).

\subsubsection{TIJDSTIP IN DE MENSTRUELE CYCLUS}

Tijdens de menstruatieperiode is een hoog percentage uitstrijkjes niet beoordeelbaar. Bij meer dan 100.000 patiënten gold dit voor $23 \%$ van de uitstrijkjes, gemaakt tijdens de eerste 4 dagen van de cyclus (Vooijs e.a. 1987). Daarna stabiliseerde dit aantal zich rond de $2 \%$.

Het percentage uitstrijkjes zonder endocervicale cellen steeg in de loop van de cyclus geleidelijk van 2 tot $7 \%$. In de hierboven wermelde studie van Allingham en King kon echter geen verband aangetoond worden tussen het tijdstip in de menstruele cyclus en het aantal endocervicalle cellen (Allingham e.a. 1985). 


\subsubsection{ONTSTEKING}

Allingham en King vonden geen verband tussen tekens van ontsteking en het voorkomen van endocervicale cellen (Allingham e.a. 1985). Frish vond een opvallend hoog aantal uitstrijkjes met atypie bij studenten, bij wie in een vorig uitstrijkje alleen tekens van onsteking gevonden werden (Frish 1987). Bij reëvaluatie van deze untstrijkjes bleek dit verschil echter volledig terug te voeren tot een foutisve aflezing van de eerste ulitstrikjes.

Andere studies ontbreken, zodat niet bekend is of het hier een toevalligheidsbevinding betreft.

Algemeen wordt aangenomen dat het bestaan van gynaecologische infecties aanleiding kan geven tor het winden van epitheelafwijkingen Imeestal lichte tot matige dysplasiel ter hoogte van de cervix, die na behandeling van de infectie niet meer gevonden worden (Anoniem 1988).

\section{2.4, ZWANGERSCHAP}

Zwangerschap kan leiden tot misclassificatie van de cytologische diagnose in vergelijking met de histologische diagnose. In een studie van Hellberg e. a. werd onderschatting van de cytologische diagnose gevonden in $47 \%$ var de uitstrijkjes met $C I N \geq \|$. Dit geldt in nog grotere mate voor een controleuitstrijkje na een afwijkend uitstrijkje en voor uitstrijkjes gemaakt tijdens de post-partum periode (Hellberge.a. 1987).

Enkele auteurs (Ayre 1948, Hamblin e.a. 1985) vonden een lager percentage uitstrijkjes met endocervicale cellen tijdens de zwangerschap.

Hierbij dient vermeld dat in vele, vooral vergelijkende studies zwangerschap als uitsiuitingscriterium gebruikt wordt.

\subsubsection{ANTICONCEPTIEGEBRUIK}

Vooijs e.a. vonden een groot aantal uitstrijkjes zonder endocervicale cellen tijdens hormonale contraceptie: $11.6 \%$ tegenover ongeveer $4 \%$ voor vrouwen met andere methoden of zonder contraceptie. Dit geldt voor de hele duur van de menstruele cyclus en brengt de auteur tot de suggestie vrouwen onder hormonale contra: ceptie vaker te screenen dan anderen, temeer daar het percentage uitstrijkjes met ernstige dysplasie of hoger bil deze vrouwen in zijn studie het dubbele bedraagt van de overeenkomende percentages bil virouwen met eenIUD; met andere anticonceptiemethoden of zonder contraceptie: 0.49 tegenover respectievelijk 0.20 , 0.25 en $0.33 \%$ (Vooils e. a. 1987 ). Elders werden in een groep van 1854 vrouwen met twee opeenvolgende uitstrijkjes zonder endocervicale cellen $45,2 \%$ gebruiksters van hormonale contraceptie gevonden tegenover $30 \%$ in een controlegroep van vrouwen waarbij wel endocervicale cellen aangetroffen werden (RR $=1.5$ ). In de onderzoeksgroep waren er 3,6\% IUD-gebruiksters tegenover $6 \%$ in de controlegroep (RR $=0.6)$ (Doornewaard e. a. 1990 ).

Bij vrouwen met een IUD worden lets meer uitstrijkjes als niet beoordeelbaar geclasseerd (Taylor e.a. 1987\%. In 104 uitstrijkjes van 25 vrouwen met een pessa. rium werd het voorkomen van "cytologische afwijkingen" gerapporteerd in maar liefst $15 \%$ van de gevallen (Kairys e.a. 1989).

In al deze studies lijkt de kans op confounding door allerhande externe factoren groot. Hiervoor wordt echter vrijwel niet gecontroleerd. 


\subsubsection{KLACHTEN EN STMPTOMEN}

In een analyse van de gegevens van het Leids bevolkingsonderzoek kon geen éenduidig verband aangetoond worden tussen het macroscopisch beeld van de cervix en de mate van CIN (Boon e.a. 1986c). Zelfs in 17 gevallen met microinvasief of invasief carcinoom werd de cervix tienmaal als normaal beschreven.

Bij een groep van 42.398 patiënten uit de huisartspraktijk betekende het vinden van een "erosie" op de cervix tweemaal zoveel kans op een afwijkend uitstrijkje als bij een normale portio; bij een "bloedende erosie" is de verhouding 4.6 en bij een verdachte portio 4.3 (Boon e.a. 1986 d).

In deze zelfde groep was het percentage patiënten met klachten over postmenopausaal bloedverlies vijf maal groter bij vrouwen met een afwijkend uitstrijkjes dan bij vrouwen met een normaal resultaat, Voor contactbloedingen was de verhouding 1.5. Tussentijds bloedverlies en fluor genitalis hadden geen duidelijke invloed. Daarbij moet vermeld worden dat het percentage vrouwen zonder klachten in geval van een pasitieve uitstrijk $92.4 \%$ was; in geval van een negatieve uitstrijk was dit $94.8 \%$.

Slot-van der Goot vond bij 354 vrouwen met een $C I N \geq 1$ na colposcopie dat het oorspronkelijk uitstrijkje in $61.8 \%$ gemaakt was zonder aanwezigheld van klachten. Bij de 199 patiënten met $C I N \geq 11$ uit deze groep bedroeg dit percentage $64.3 \%$ (Slot-van der Goot 1991). In een uitgebreide Australische studie bij ruim tweeduizend vrouwen met histologisch bewezen dysplasie of meer (Mc Cormak e.a. 1988) daalde het percentage vrouwen zonder klachten van $74 \%$ voor dysplasie progres. sief tot $20 \%$ voor invasief carcinoom stadium 4 .

\subsection{Intravaginale manipulaties}

Uitstrijkjes gemaakt van 44 pas verwijderde conussen, gaven in $86 \%$ vals negatieve resultaten (Rubio e,a. 1974). De auteurs wijten dit aan de zorguuldige preoperatieve ontsmetting van de portio, waardoor de oppervlakkige epitheellaag grotendeels verwijderd wordt. De auteurs waarschuwen op basis van deze bevindingen voor allerlei traumatiserende ingrepen in de periode voor de afname van een uitstrijkje. Er kan daarbij gedacht worden aan desinfectiemiddelen, lubrificerende producten, het verrichten van een vaginaal toucher voor het uitstrijken, vaginale spoelingen en coïtus.

In dit verband vonden Griffiths e.a. dat het uitvoeren van een colposcople voor het uitstrijken aanleiding gaf tot $9 \%$ inadequate uitstrijkjes en tot $53 \%$ vals negatieve resultaten (Griffiths e.a. 1989).

\subsection{Een tweede uitstrijkje}

Het lijkt logisch dat de afname van een tweede uitstrijkje, meteen na het eerste de kans op het vinden van endocervicale, respectievelijk pathologische cellen in ben van beide uitstrijkjes verhoogt. Uit een gemiddelde berekening van drie onderzoe. ken (Beibly e.a. 1982, Luthy e.a. 1987, Sedlis e.a. 1974) zou de kans op het vinden van pathologie zelfs met een derde toenemen, ook al wordt tweemal dezelfde afnametechniek gebruikt. (tabel 1.4). 
Tabel 1.4: Winst in aantal pathologische cellen door het onmiddellijk maken van een tweede uitstrijkje met hetzelfde afnamemateriaal (cut-off is lichte dysplasiel

\begin{tabular}{|c|c|c|c|c|c|c|}
\hline $\begin{array}{l}\text { मge } \\
2\end{array}$ & wadr & $\begin{array}{l}\text { Tot alantal } \\
\text { potienter }\end{array}$ & 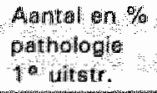 & $\begin{array}{l}\text { Extra winst } \\
2 \text { e uitstrijle }\end{array}$ & $\begin{array}{l}\text { Interpretatie } \\
\text { door zelfide } \\
\text { laboratorium? }\end{array}$ & $\begin{array}{c}\text { Afname materialal } \\
\text { a }\end{array}$ \\
\hline 191 & 1974 & 17,737 & $184,[0,92\}$ & 87 & neten & axt tip \\
\hline 142 & 1987 & 3.624 & 1410.40 & 6 & ja & Avre - of Ext sip \\
\hline $14=\cdot 3$ & 1982 & 10,862 & 3201008 & $79=$ & meen & Avre of Exttip \\
\hline Toteras & & 31.923 & $498(1.56)$ & 171 & 15 & \\
\hline
\end{tabular}

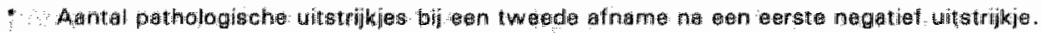

- Hat ersitanomon uitstrikje bevat toweng material vag de achierste fornix.

*. Deza atuleurs gebruken omen eigen indeling wain de pathologie. Cut off is hier "suspicious".

Over de relatieve oogst aan allerhande cellen in twee elkaar opvolgende uitstrikjes bestaat overigens nog discussie: én auteur (Trimbos e.a. $1986 \mathrm{f}$ vermeld dat in het eerste uitstrijkje duidelijk meer mucus en (dus?) meer cellen gevonden worden. Een andere (Stock e. a. 1988) vond juist in het tweede uitstrijkje een grotere celrijkdom en meer endocervicale cellen, naast meer bloed en meer pathologische cellen.

Wanneer men een uitstrijkje na enige tiid wil herhalen, bijvoorbeeld ter bevestiging van een afwijkend resultaat, moet altijd geruime tijd gewacht worden tot de reparatiereactie verdwenen is Zo werden bij een tweede uitstrijkje na een "atypisch" beeld in $60 \%$ van de gevallen vals negatieve resultaten verkregen bij patiënten die later duidelijke afwijkingen bleken te hebben (Holm e.a. 1989).

Een andere auteur vond bij een controle-uitstrijkje binnen 3 maanden van patiènten met een eerste afwijkend uitstrijkje (Low Grade SIL) in $31.7 \%$ geen afwijkingen terug (Meisels 1990\%.

\section{Invloed van het afnamemateriaal}

Toen Papanicolaou en Traut hun techniek voor het maken van een 'vaginal smear" ontwikkelden, zochten zij naar een manier om cellen te verzamelen, die afgeschilferd waren van een carcinoom, ergens in de tractus genitalis van de vrouw. $\mathrm{Zij}$ aspireerden met een pipet en een rubberen peertje de vaginale secreties uit de achterste fornix omdat zif gevonden hadden dat afgeschilferde cellen zich op die plaats verzamelden (Papanicolaou e.a, 1941). De afname gebeurde blind: er werd geen speculum ingebracht:

De resultaten, die snel door anderen bevestigd werden, waren hoopgevend: met een zeer eenvoudige en nauwelijks belastende test werd de diagnose gesteld van een waaier van gynaecologische maligniteiten. Toch waren er problemen. Vaak gebeurde de aspiratie op de verkeerde plaats: ter hoogte van de voorwand van de vagina of zelfs even voorbij de introïtus. De concentratie van afwijkende cellen in 
het slijm was laag, wat tot een lange microscopieduur noopte en vals negatieve resultaten als gevolg had.

De Canadees Ayre zocht en vond enkele jaren later een oplosing hiervoor. Na het inbrengen van een speculum aspireerde hij, met hetzelfde materiaal als zujn voorgangers, slijm ter hoogte van het ostium cervicis in plaats van ter hoogte van de fornix posterior. Hierdoor steeg de concentratie afwijkende cellen in het siljm aanzienlijk (Ayre 1948), In een tweede fase gebruikte hij een houten spatel om de volledige omtrek van de overgangszone af te schrapen (Ayre 1947). Hierdoor verzamelde hij afwijkende cellen, nog voor het moment dat zij afschilferden en terwijl zij in een veel betere conditie waren. Hij sprak dan ook van een "oppervlaktebiopsie". Deze techniek maakte het voor het eerst mogelijk om naast kankercellen, ook cellen te verzamelen van klinisch nog niet zichtbare " vroege" vormen van cervixcarcinoom ("early cervical cancers"). Een logisch gevolg hiervan was dat hij ging pleiten voor een jaarlijks cytologisch onderzoek van alle vrouwen, ook bij afwezigheid van symptomen. Wellicht is het nuttig eraan te herinneren dat Ayre in 1948 reeds pleitte voor het maken van twee uitstrijkjes, eén door aspiratie ter hoogte van het ostium en een tweede via "selectief schrapen" van de overgangszone (Ayre 1948).

Later raakte de aspiratie om onduidelijke redenen vrijwel volledig in onbruik. Nog later werd vastgesteld dat in veel uitstrijkjes alleen plaveiselcellen gevonden werden. Men concludeerde terecht dat in een groot aantal gevallen de overgangszone gemist werd en men ging op zoek naar nieuwere en betere afnameinstrumenten, teneinde in een zo groot mogelijk aantal gevallen op de correcte plaats uit te strilken.

Meer dan veertig jaar later is een hele reeks afnametechnieken uitgeprobeerd. In een groot aantal onderzoeken is daarbij ook gepoogd om de relatieve waarde van deze methoden te evalueren.

In dit overzicht verzamelen wij studies naar het effect van verschillende afnametechnieken op het percentage pathologische uitstrijkjes en het percentage uitstrijkjes waarin endocervicale cellen, respectievellik plaveiselcellen gevonden worden.

Vier mogelijke designs worden onderscheiden:

1. Vergelijking van werschillende technieken bij eenzelfde patiënte.

2. Vergelijking van verschillende technieken bij al dan niet gerandomiseerde groepen van verschillende patiënten.

3. Registraties van de resultaten van een techniek zonder controle of vergelijkingsgroep (pick-up rate)

4. In vitro onderzoek.

De overtuigingskracht van deze designs voor het kiezen van een "beste methode" neemt af in de volgorde waarin zij hier opgesomd zijn. Daarbij worden de resultaten van onderzoeken uit een voorafgaande categorie telkens mee verwerkt in samenvattingen en tabellen van volgende categorieën.

In de tabellen uit dit hoofdstuk wordt bij de verschillende vergelifkende studies telkens vermeld of de toewijzing van twee vergeleken technieken via randomisatie 
gebeurde, dan wel of er sprake is van een historische controlegroep waarbij beide technieken in totaal verschillende periodes toegepast worden.

Als gerandomiseend worden daarbij beschouwd:

- studies op gepaarde uitstrijkjes, afkomstig van eenzelfde patiente.

- Voor iedere patiente wordt door het toeval bepaald welke techniek gebrukt wordt (klassieke randomisatie).

- De gebrukte techniek wordt ledere dag of iedere week gewissell en in de loop van een zelfide dag of week worden alle patienten volgens dezelfole methode uitgestreken.

\subsection{Verband tussen afnamemethode en pathologie}

\subsubsection{GEPAARDE UITSTRIJKJES, AFKOMSTIG VAN DEZELFDE PATIËNTEN}

Deze studies zujn meestal uitgevoerd bij vrouwen die voor verder onderzoek verwezen zijn naar aanleiding van een eerder, afwijkend uitstrijkje.

In een aantal gevallen wordt de sensitiviteit gebruikt als basis voor de vergelijking van de verschillende methoden. Daarbij stelt zich uiteraard de vraag naar de specificiteit. In cervixcytologie is het bepalen van de specificiteit erg moeilijk omdat daarvoor een analyse nodig is van uitstrijkjes, afgenomen bij vrouwen van wie bekend is dat zij geen afwijkingen hebben op basis van een gouden standaard, traditionee het histologisch onderzoek. Dit gebeurt vrijwel nooit. De laatste jaren zijn er specificiteitsstudies verricht door thet volgen in de tijd van vrouwen met normale en met abnormale cervixuitstrijkjes. Wij vonden echter geen studie waarbij dit gebeurde voor de vergelijking van verschillende afnamemethoden.

\section{Wattenstok versus Spatel van Ayre}

Het gebruik van de wattenstok is vergeleken met de Spatel van Ayre in een studie waarbil) ook histologische gegevens beschikbaar zijn (Johansen e.a. 1979).

Bij een afkappunt op matige dysplasie berekenden wij uit deze gegevens een sensitiviteit van $75 \%$ voor de spatelafname en $81 \%$ voor de wattenstok.

Bij een afkappunt op ernstige dysplasie vinden wij een sensitiviteit van $71 \%$ voor de spatelafname en $52 \%$ voor de wattenstak.

Dit suggereert dat de spatel een beter detectiemiddel zou zijn voor ernstiger afwijkingen, terwijl de wattenstok het beter doet bij minder ernstige afwijkingen.

\section{Spatel + Cytobrush versus spatel}

Do combinatie van een spatel-en een Cytobrushuitstrijk is in drie Nederlandse studies vergeleken met de extended-tip spatel (tabel 1.5$)$.

Van Erp e.a. vonden met de spatel alleen $80 \%$ van het aantal pathologische uitstrijkjes, dat gevonden werd met de combinatiemethode, met lichte dysplasie als afkappunt (van Erp e.a. 1988). Als wij het afkappunt op ernstige dysplasie of C.I.S. stellen, wordt dit $77 \%$.

Vergelitikbare resultaten werden gevonden in een groep van 632 vrouwen die een spreekuur voor geboorteregeling bezochten (van Erp e.a. 1989).

Bij 412 pathologische uitstrijkjes, uit een reeks van 444 , afgenomen met de spatel + Cytobrushcombinatie, werden pathologische cellen gevonden in $90 \%$ van de spateluitstrijkjes en in $97 \%$ van de Cytobrushuitstrijkjes. Het afkappunt lag daarbij 
op $\geq$ lichte dysplasie en de hoogst gevonden waarde voor de combinatie gold als standaard (Buntinx e.a. 1991 ).

In een omgekeerde setting werden uitstrijkjes vergeleken met een cytologische diagnose CIN $\geq 111 \mathrm{~b}$ (Alons-van Kordelaare.a. 1988). Als standaard werd in deze studie de histologische einddiagnose gebruikt. Daarbil werd een overschatting van de diagnose gevonden in $19 \%$ van de spateluitstrijkjes en in $20 \%$ van de uitstrijkjes met de combinatiemethode. De combinatietechniek lijkt dus geen aanleiding te geven tot toename in overdiagnostliek.

Tabel 1.5: Relatief risico voor het percentage pathologische uitstrijkjes afgenomen met Spatel + Cytobrush versus Spatel alleen

\begin{tabular}{|c|c|c|c|c|c|c|}
\hline Fet & $\begin{array}{l}\text { Aantal } \\
\text { peren }\end{array}$ & $\begin{array}{r}0 / \mathrm{Pap} \\
\text { spatel }+\mathrm{Cbt} .\end{array}$ & $\begin{array}{l}\text { llla } \\
\text { spatel }\end{array}$ & RR & $95 \%$ B & Opmerkingen \\
\hline 74 & 130 & 34 & 27 & 1.26 & $0.87 \cdot 1.82$ & na afwijkend uitstritkje \\
\hline 32 & 444 & 93 & 83 & 1,112 & $1.06 \cdot 1.17$ & $\begin{array}{l}\text { vooral pothologische uit } \\
\text { sirilkjes }\end{array}$ \\
\hline 76 & 632 & 71,6 & 10.0 & $\# .16$ & 0.84150 & family planniryg clinto \\
\hline
\end{tabular}

$\mathrm{AR}_{\mathrm{m} n}=1.11(1.05 \cdot 1.18)$

Omdat in deze studies gebruik gemaakt wordt van hoofdzakelijk afwijkende uitstrijkjes, is een odds ratio hier geen benadering van het relatief risico. Wij berekenden daarom een gepoold $\mathrm{RR}_{\mathrm{m} / \mathrm{s}}$ in plaats van een $O \mathrm{R}_{\mathrm{mhk}}$. Dezelfde opmerking geldt overigens voor tabel 1.6

\section{Spatel van Ayre versus Multispatula}

In een reeks uitstrijkjes bij patiënten, verwezen ter controle van een afwijkend uitstrijkje (Pistofides e.a. 1988), werd de multispatula vergeleken met de Spatel van Ayre. De auteurs vinden lichte dysplasie of hoger in $82 \%$ van de Ayre-afnames en in $94 \%$ van de multispatula-afnames. Het verschil in vals negatieve uit.strijkjes tussen beide technieken is $12.7 \% 195 \% \mathrm{BI}=4.6-19.41$,

\subsubsection{VERGELIJKINGEN TUSSEN GROEPEN VAN VEASCHILLENDE PATIËNTEN}

Waar zulks zin heeft werden de resultaten van de verschillende studies gepoold wolgens de in de inleiding beschrever techniek, teneinde een gewogen gemiddelde te verkrijgen. Het resultaat is een Mantel-Haenszel schatting van het relatief risico voor het percentage pathologische uitstrijkjes, gemalat met de twee vergeleken technieken, wat wij afkorten als RR1 mh of RR3mh, alnaargelang die betrekking heeft op pathologie, geklassificeerd als CIN $\geq 1$ of CIN $\geq \| I 1$.

\section{Spatel + Cvtobrush versus Spatel alleen}

Het relatief risico werd mede berekend op basis van twee studies, afkomstig uit hetzelfde centrum, de ene (Alons-van Kordelaar e.a. 1988) uitgevoerd bij huis- 
artsen en de andere (Boon e.a: 1989) bij professionele uitstrijksters van een bevolkingsonderzoek (tabel 1.6).

Ook een Amerikaanse groep deed een dergelik onderzoek. In de ons ter beschikking staande publicatie (Kuo e.a. 1990) vermelden zij echter alleen percentages en geen absolute aantallen. Wij hebben hun gegevens daarom miet opgenomen in de pooling: Bij een afkappunt op $\geq$ Low Grade (respectiewelijk High Grade) SIL: vonden zilj pathologie in $0.79(0.30) \%$ van de spateluitstrijkjes en in $1.63(0.58) \%$ van de uitstrijkjes na het toevoegen van de Cytobrush aan de afnameprocedure. Wij komen tot een RR van 2.06 (2.81).

Tabel 1.6: Rela tief risico voor het percentage pathologische uitstrijkjes, gemaakt met de gecombineerde Spatel + Cytobrushmethode versus de Spatel alleen $(+95 \%$ betrouwbaarheidsinterval)

\begin{tabular}{|c|c|c|c|c|c|c|}
\hline Aal. & 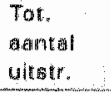 & $\mathrm{CIN} \geq 1$ & CIN $\geq 131$ & $\begin{array}{l}\text { Rando } \\
\text { misetie? }\end{array}$ & $\begin{array}{l}\text { Ged } \\
\text { paard? }\end{array}$ & Opmerkingen \\
\hline $\begin{array}{r}3 \\
3 \\
\end{array}$ & $31: 468$ & . & $\begin{array}{c}2.89 \\
(2.46-3.40)\end{array}$ & neen & nean & $\begin{array}{l}\text { hwisartsen } \\
\text { histiologische controle }\end{array}$ \\
\hline 21 & 13.282 & $\begin{array}{c}1.23 \\
(0.78-1.93)\end{array}$ & $\begin{array}{c}1.66 \\
(0.70 \times 3.94)\end{array}$ & ja & neen & $\begin{array}{l}\text { Uitstrilksters } \\
\text { bevalkingsonderzook }\end{array}$ \\
\hline $\begin{array}{l}74 . \\
8 \\
\end{array}$ & $\begin{array}{r}260 \\
-\quad \square \\
\end{array}$ & $\begin{array}{c}1.26 \\
(0.87 \times 1.82)\end{array}$ & . & ja & 相 & $\begin{array}{l}\text { controle na afwikend uit- } \\
\text { strijhia. }\end{array}$ \\
\hline $\begin{array}{l}32 \\
3\end{array}$ & 888 & $\begin{array}{c}1.12 \\
(1.06-1.17)\end{array}$ & $\therefore$ & ja & ja & $\begin{array}{l}\text { voorall pathologische uit. } \\
\text { strijkjes }\end{array}$ \\
\hline 76 & 1264 & $\begin{array}{c}1.16 \\
(0.84 \cdot 1.59)\end{array}$ & . & ఏa & ja & "family planning cläric" \\
\hline
\end{tabular}

- raspectiewelifis PAP $\geq$ III

FH $1 \mathrm{mh}=1.14(96 \%$ B $=1.06 \cdot 1.22)$

$\mathrm{AR} 3 \mathrm{mh}=2.08(95 \%$ BI $\approx 2.01-2.15)$

Spatel + Cytobrush versus Cervex

Uit de studie van Boon e.a. berekenden wij op basis van in totaal 6.033 uitstrijkjes een RR van $1.31(95 \% \mathrm{~B} \|=0.69-2.47)$ bij een afkappunt op CIN $\geq \mathrm{I}$ en $\mathrm{RR}=$ $1.43(95 \% \mathrm{Bi}=0.44-4.64)$ bij een afkappunt op CIN $\geq I I I$ (Boon e.a.1989).

Extended tio spatel versus Spatel van Ayre

Drie studies (Gay e.a. 1985, Goorney e.a. 1989, Wolfendale e.a. 1987) werden gevonden. Zij komen alle uit Groot-Brittannië. Het gaat telkens om screeninguitstrijkjes (tabel 1.7). 
Tabel 1.7: Relatief rilsico voor het percentage pathologische uitstrijkjes, gemaakt met de extended-tip spatel versus de spatel van Ayre $1+95 \%$ betrouwbaarheidsinterval)

\begin{tabular}{|c|c|c|c|c|c|}
\hline Ret. & $\begin{array}{l}\text { Toteal } \\
\text { aantal }\end{array}$ & $C \mathbb{N} \geq 1$ & $C\|N \geq\|$ & Riandont? & Opmerkingen \\
\hline 235 & 15.833 & $\begin{array}{c}1.21 \\
(1.02-1.44)\end{array}$ & $\begin{array}{c}1.38 \\
1.00-1.911\end{array}$ & + & scrooning \\
\hline 85 & 1.111 & $\frac{1.83}{(1.08-3,11)}$ & 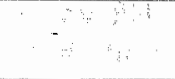 & - & scroening \\
\hline 92 & 4.080 & $\begin{array}{c}0.98 \\
(0.701 .36)\end{array}$ & $\begin{array}{c}0.71 \\
10.331 .531\end{array}$ & $+\cdots$ & genito-trinary medicinge \\
\hline
\end{tabular}

$\mathrm{OR} I \mathrm{mh}=1.20195 \% \mathrm{BI}=1.19-1.211$

$\mathrm{OR} 3 \mathrm{mh}=1.25(96 \% \mathrm{Bl}=1.20-1.31)$

Cytobrush versus wattenstok

Tabel 1.8: Relatief risico voor het percentage pathologische uitstrijkjes, gemaakt met de spatel + Cytobrush versus de spatel + wattenstok $1+95 \%$ betrouwbaarheidsinterval)

\begin{tabular}{|c|c|c|c|c|c|c|}
\hline Ret. & $\begin{array}{l}\text { Aantal } \\
\text { uitstrijkjes }\end{array}$ & CIN $\geq 1$ & $\mathrm{CIN} \geq \|$ & $\begin{array}{l}\text { Rando- } \\
\text { misa- } \\
\text { tie? }\end{array}$ & $\begin{array}{l}\text { Gepard? } \\
\therefore \quad:\end{array}$ & Opmerkingen \\
\hline 157 & 811 & $\begin{array}{c}3.67 \\
(1.06-12.7)\end{array}$ & $\therefore \quad \therefore$ & neern & nem & . \\
\hline 26 & 7.342 & $\begin{array}{c}1.24 \\
(0.69-2.23)\end{array}$ & $\begin{array}{c}1.74 \\
(0.54 \cdot 5.59)\end{array}$ & ja & neen & $\begin{array}{l}\text { Witstritketers bevol- } \\
\text { kingsondierzoek }\end{array}$ \\
\hline
\end{tabular}

- of PAP z llla

ORithth $=1.56(0.87 \cdot 2.79)$

Glenthoj e.a. publiceerden een vergelijkende studie bij 100 opeenvolgende vrouwen, die na de afname van het uitstrijkje een conisatie ondergingen: Voor het afnemen van het uitstrijkje werden zij at random verdeeld in een wattenstokgroep en een Cytobrushgroep. Telkeris werd zowel een endocervicale ais een ectocervicale afname verricht met als instrument hetzij de Cytobrush alleen, hetzij de wattenstok alleen (Gllenthoj e.a. 1988). Omdat wij voor alle patiënten over een histologische diagnose beschikken, kunnen wij de sensitiviteit als vergelijkingspunt gebruiken.

Met een afkappunt op CIN I vinden wij een sensitiviteit van $96 \%$ voor de Cytobrush en $65 \%$ voor de Wattenstok.

Met een afkappunt op CIN III wordt dit $76 \%$ voor de Cytobrush en $32 \%$ voor de Wattenstok. 


\section{Cytobrush alleen versus Extended-tip spatel}

Twee groepen van elk ruim 800 uitstrijkjes werden vergeleken (Vooijs 1988). Bij een afkappunt op CIN I bedroeg het percentage afwijkende uitstrijkjes $1.76 \%$ voor de spatel en $0.24 \%$ voor de Cytobrush alleen. Bii een afkappunt op CIN Ill wordt dit $0.59 \%$ voor de spatel en $0.12 \%$ voor de Cytobrush alleen. Het relatief risico op het vinden van pathologie is dus respectievelijk 7.3 (CIN I) en 4.9 (CIN III).

\section{Cervex versus Extended-tip spatel}

Uit twee Nederlandse, maar onafhankelijk van elkaar uitgevoerde studies (Boon e.a. 1989, Vooijs 1988) blijkt geen significant verschil in het aantal gevonden afwijkende uitstrijkjes (tabel 1.9). Dit geldt zowel voor een afkappunt op CIN I als op CIN III. Bij pooling van beide studies verandert dit beeld niet.

In een Australische studie (Laverty e.a. 1989) vond men wel duidelijk meer "atypie" ( $p=0.026)$ bij Cervexuitstrijkjes.

Tabel 1.9: Relatief risico voor het percentage pathologische uitstrijkjes gemaakt met de Cervex versus de extended-tip spatel $1+95 \%$ betrouwbaarheidsintervall

\begin{tabular}{|c|c|c|c|c|c|}
\hline hef: & $\begin{array}{l}\text { Totanal antic. } \\
\text { uitstrijkjes }\end{array}$ & atyple & $\mathrm{CIN} \geq 1$ & CIN $\geq 11 !$ & Randomisatie \\
\hline 223 & 1.464 & - & $\begin{array}{c}11.13 \\
(0.74-1.73)\end{array}$ & $(0.41-2.10)$ & + \\
\hline 26 & 11.767 & - & $\begin{array}{c}0.94 \\
(0.55-1.60)\end{array}$ & $\begin{array}{c}1.16 \\
10.44-3.099\end{array}$ & 4 \\
\hline 138 & $*$ & $\begin{array}{c}1.32 \\
(1.11-1.57)\end{array}$ & . & . & . \\
\hline
\end{tabular}

- 982 Cervex-uitstrijkjes wergeteken met ongeverer 60,000 Extended-tip uitstrijkjes.

OR1 $\mathrm{mm}=1.00(0.94 \cdot 1.06)$

$\mathrm{OR} 3 \mathrm{~mm}=1.0 \mathrm{~B}(0.69 \cdot 1.69)$

\section{Spatel + Wattenstok versus Spatel van Ayre}

Garite en Feldman vergeleken de Spatel + Wattenstok combinatie $(n=173)$ met de Spatel van Avre $(n=222)$. Zij vonden duidelijk meer afwijkende cellen $(\geq \mathrm{CIN} \|)$ in de combinatie uitstrijken: $R R=2.44(95 \% \mathrm{BI}=1.16-5.11)$ (Garite e.a. 1978). In een veel grotere studie $(n=12.340)$ werden daarentegen geen duidelijke verschillen in percentage afwijkende uitstrijkjes gevonden: $R R=0.99(0.60-1.64)$ bij een afkappunt op $\mathrm{CIN} \geq \mathrm{I}$ en $\mathrm{RR}=0.95(95 \% \mathrm{BI}=0.36-2.53)$ bif een afkappunt op $\mathrm{CIN} \geq$ III (Boon e.e. 1989).

Deze resultaten werden niet gepoold omdat er een reële kans op heterogeniteit bestaat. Beide studies waren gerandomiseerd.

\section{Cytopick}

De Cytopick werd vergeleken met de Spatel alleen, Spatel + Cytobrush, Spatel + Wattenstok en Cervex (Boon e.a. 1989). Uit de resultaten berekenden wij de volgende RR's, die geen van alle een significant verschil aangeven (tabel 1.10). 
Tabel 1.10: Relatief risico voor het percentage pathologische uitstrijkjes afgenomen met 4 verschillende afname-instrumenten versus de Cytopick I+ $95 \%$ BI). Alle gegevens zijn afkomstig van én grote studie (Boon e.a. 1989)

\begin{tabular}{|c|c|c|c|c|}
\hline Afkappun & $\begin{array}{l}\text { Spatel Hytobrush/ } \\
\text { Cytopick }\end{array}$ & Cervax/Cytopick & Spatel/Crtopick & $\begin{array}{l}\text { Spateit Watti } \\
\text { Cytapick }\end{array}$ \\
\hline $\operatorname{CIN} \geq 1$ & $\begin{array}{c}1.13 \\
0.65-1.98\end{array}$ & $\begin{array}{c}0.86 \\
10.44-1.701\end{array}$ & $\begin{array}{c}0.92 \\
10.651 .521\end{array}$ & $\begin{array}{c}0.91 \\
(0.49 \cdot 1.71)\end{array}$ \\
\hline $\mathrm{CIN} \geq 111$ & $\begin{array}{c}1.03 \\
0.38-2.761\end{array}$ & $\begin{array}{c}0.74 \\
(0.22 \cdot 2.53)\end{array}$ & $\begin{array}{c}0.63 \\
10.25 \cdots 1.59\end{array}$ & $\begin{array}{c}0.61 \\
(0.782 .08)\end{array}$ \\
\hline
\end{tabular}

\section{Afnametechniek volgens het uitzicht van de portio}

In een gerandomiseerde studie werd het voorkomen van dysplasie vergeleken in uitstrijkjes gemaakt met de spatel van Ayre $(n=222$ ) of met de combinatie van spatel van Ayre en wattenstok ( $m=173$ ) enerzijds ten opzichte van uitstrijkjes waarbij ofwel alleen een spatelafname ofwel een spatel plus wattenstokafname verricht werd volgens het al dan niet klinisch zichtbaar zijn ("everted") van een erythroplakie op de portio $(n=252)$. Er werd geen verschil gevonden tussen de spateluitstrijkjes (dysplasie in $4.5 \% ; 95 \%$ Bl $=2.2-8.1$ ) en de uitstrijkjes waarbij de afnametechniek bepaald werd door het klinisch beeld (dysplasie in $5.2 \%$; $95 \%$ $\mathrm{BI}=2.8-8.7)$. De gecombineerde afnametechniek leverde een oogst van $11.0 \%$ $(95 \% \mathrm{BI}=6.3-15.6)$ uitstrijkjes met dysplasie (Garite e.a. 1978).

\subsubsection{IN VITRO PROEVEN}

Rubio publiceerde met zijn medewerkers uit het Karolinska Instituut, gedurende de laatste vijftien jaar een serie artikellen, gebaseerd op onderzoek met een in vitro bereide samenstelling van kankercellen in slijm. Hij vergeleek daarbij onder meer de invloed van verschillende afnameinstrumenten op de oogst aan uitgestreken cellen. Uit histologisch en electronenmicroscopisch onderzoek van de instrumenten nadat zij op het glaasje afgestreken waren (Rubio 1977b), vond hij dat houten spatels en wattenstokjes in sterke mate (afwijkende) cellen gevangen houden in hun vezels (respectievelijk in $62 \%$ en $79 \%$ van de instrumentjes). Hij gebruikt daarbij het woord "trapped". Een voorbehandelling van de instrumenten met silicone veranderde dit nauwelijks. Bij plastic spatels werd het effect in veel kleinere mate gevonden $(7 \%)$. Wellicht is dit effect vooral belangrijk als er weinig afwijkende cellen voorhanden zijn (Rubio e.a. 1974).

Uit een latere studie (Rubio e.a. 1979) blijkt echter dat het aantal pathologische cellen dat achteraf op het glaasje gevonden wordt, niet duidelik verschilt na een afname met een houten of plastic spatel. Mogelijk compenseert in witstrijkjes met een houten spatel een hoger aantal uitgestreken cellen voor een hoger aantal weerhouden ("gevangen" "y cellen.

Bij houten spatel- en bij wattenstokuitstrijkjes, afgestreken via parallelle streken, vindt men een opeenstapeling van pathologische cellen, halfweg het glaasje. Bij uitstrijkjes, gemaakt met de plastic spatel, is de verdeling over het glaasje meer homogeen (Rubio e.a. 1980b). 


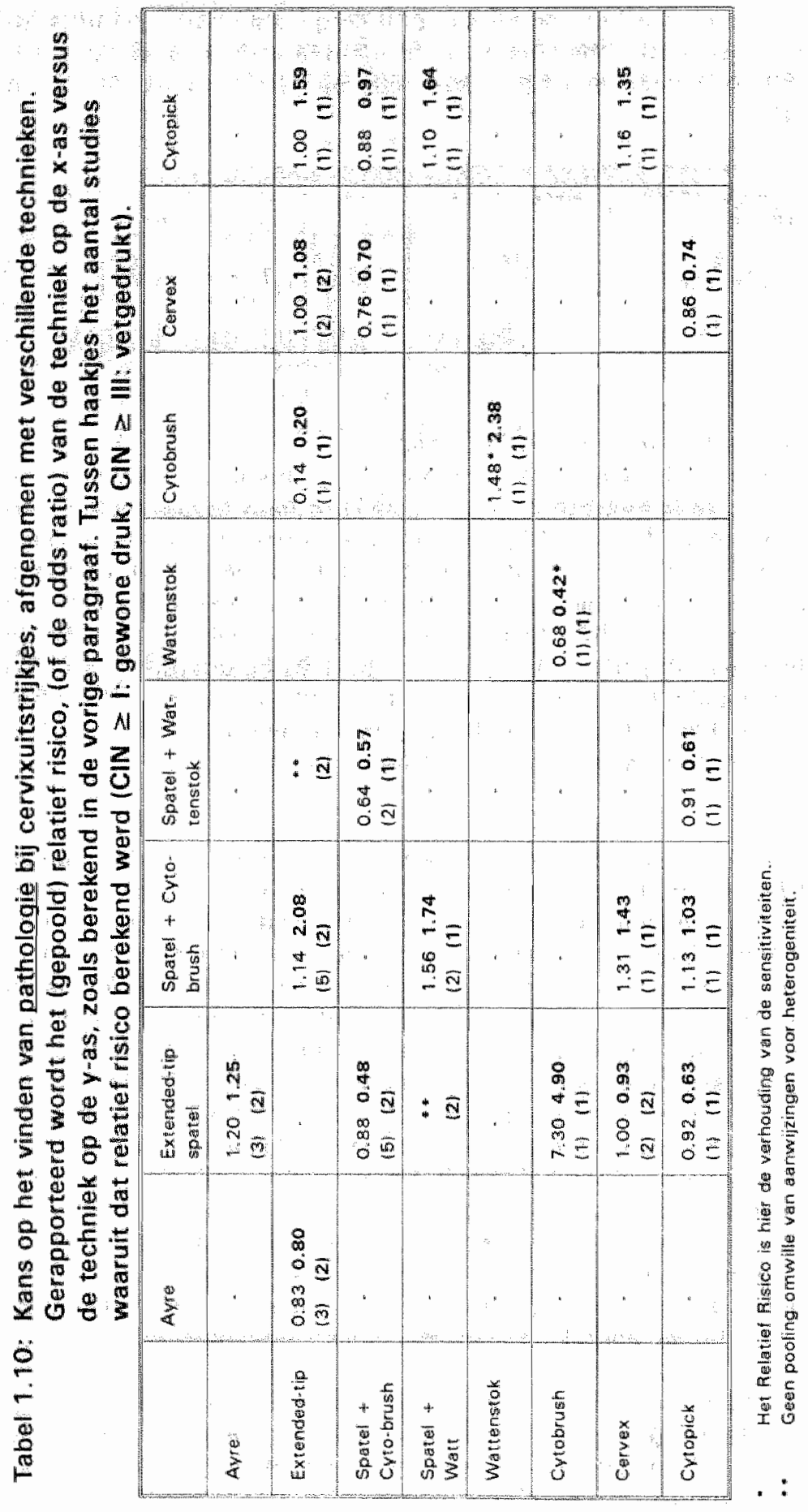


Als bij uitstrijkjes, afgenomen met de houten spatel, eerst afmijkende cellen opgepakt worden en later normaal mucus, is er meer kans dat de afwijkende cellen op de spatel achterbijven dan als het uitstrijken in de omgekeerde volgorde gebeurt (Rubio e.a. 1980b). Helaas kan deze kennis in het klinisch werk niet te nutte gemaakt worden, omdat de letsels meestal niet zichtbaar zijn met het blote oog.

3.1.4. SAMENVATTING VAN DE RESULTATEN

De resultaten van de vergelijkende studies uit sectie 3.1 worden samengevat in tabel 1.10 .

\subsection{Verband tussen afnametechniek en het vinden van endocervicale cellen}

\subsubsection{GEPAARDE UITSTRIJKJES, AFKOMSTIG VAN DEZELFOE PATIËNTEN}

\section{Wattenstok versus Cytobrush}

In ons overzicht hebben wij voor éen studie (Kawaguchi e.a. 1987) gebruik gemaakt van aantallen, die niet als zodanig in het artikel vermeld $z$ ijn, maar die wij afgeleid hebben uit de gepubliceerde figuur:

Tabel 1.11: Relatief risico op afwezigheid van endocervicale cellen in uitstrijkjes gemaakt met de wattenstok-(watt), versus de Cytobrush-(Cbr) (gepaarde uitstrijkjes)

\begin{tabular}{|c|c|c|c|c|c|c|c|c|}
\hline Ref & $\begin{array}{l}\text { Aanital } \\
\text { paren }\end{array}$ & Watt & cbr & $\mathrm{RF}_{\mathrm{i}}$ & $95 \% \mathrm{BI}$ & $\begin{array}{l}\text { teven } \\
\text { Wath }\end{array}$ & Cor. & Opmerkingen \\
\hline 212 & 30 & 70 & 10 & 7.0 & $40-12.2$ & . & : & $\begin{array}{l}\text { verwezen pat. warbif in een } \\
\text { vorig witsir. blean endocerv. } \\
\text { cellen gewanden werden }\end{array}$ \\
\hline 98 & 100 & 61 & 3 & 20.3 & 11.5 .36 .1 & +4. & . & $\begin{array}{l}\text { metaplasnische callen bij de } \\
\text { endocerv celler opgateld }\end{array}$ \\
\hline 121 & 813 & 52 & 22 & $2 \cdot 4$ & $2.2 \cdot 2.6$ & . & . & 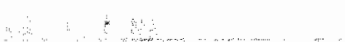 \\
\hline 29 & 100 & 6 & 0 & $O N$ & & . & . & . \\
\hline 135 & 66 & 39 & 20 & 2.0 & $1.1 \cdot 3.5$ & + & + & conisatio in des anderronoso \\
\hline
\end{tabular}

ON: preindig

De $\mathrm{OR}_{\mathrm{min}}=4.00195 \% \mathrm{BI}=3.23 \cdot 4.951$

In drie studies (Brink e.a. 1989, Kawaguchi e.a. 1987. Trimbos e.a. 1986) wordt de afwezigheid van endocervicale cellen nagegaan in uitstrijkjes die uitsluitend met de Cytobrush, dan wel met de wattenstok gemaakt zijn.

In één studie (Gupta e.a. 1987) wordt de afwezigheid van endocervicale cellen geteld in uitstrijkjes gemaakt met de combinatie van spatel + wattenstok en in uitstrijkjes gemaakt met de Cytobrush alleen. 
Kristensen e.a. vergeleken uitstrijkjes gemaakt met spatel + wattenstok versus spatel + Cytobrush bij 66 patienten bij wie tevoren een conisatie gebeurde wegens CIN IIIIII (Kristensen e.a. 1989b). De volgorde van de afnames was gerandomiseerd. Het percentage uitstrijkjes zonder endocervicale cellen bedroeg $39.4 \%$ in de eerste groep en $19.7 \%$ in de tweede. $\mathrm{RR}=2.00195 \% \mathrm{Bl}=1.13-3.541$.

Elders vond men tot $100 \%$ aanwezigheid van endocervicale cellen in uitstrijkjes, gemaikt met de Cytobrush, maar waarbil de Cytobrush uitgespoeld werd in een oplossing die achteraf microscopisch onderzocht werd (Gupta e.a. 1987).

\section{Spatel van Ayre versus Multispatula}

Twee recente studies (Pistofides e.a. 1988, Vierhout 1987) vergelijken het voorkamen van endocervicale cellen bij deze afnametechnieken (tabel 1.12). Blijkbaar leidt de afname met de multispatula tot een minder frekwent afwezig zijn van endocervicale cellen dan de afname met de spatel van Ayre.

Tabel 1.12: Relatief risico op afwezigheid van endocervicale cellen bij uitstrijkjes gemaakt met de spatel van Ayre versus de multispatula Igepaarde uitstrijkjes)

\begin{tabular}{|c|c|c|c|c|c|}
\hline Ref & Aantal partin & $\begin{array}{l}\text { \%ono } \\
\text { spatel van Ayra }\end{array}$ & mulltispotula & RA & $95 \% \mathrm{~B}$ \\
\hline 166 & 158 & 45.6 & 12.7 & 3,6 & $3.42-3.79$ \\
\hline 221 & 236 & 33.1 & 20.3 & 1.6 & $1.36 \cdot 1.88$ \\
\hline
\end{tabular}

Spatel van Ayre versus Cytobrush

Vijf verschillende auteurs vergeleken spatel- en Cytobrushuitstrijkjes tijdens eenzelfde ráadpleging afgenomen bij dezelfde patiënten.

Tabel 1.13: Relatief risico op afwezigheid van endocervicale cellen in witstrijkjes gemaakt met de spatel, versus de Cytobrush (gepaarde uitstrijkjes)

\begin{tabular}{|c|c|c|c|c|c|c|}
\hline Rot. & $\begin{array}{l}\text { Aariat } \\
\text { paran }\end{array}$ & spatel & Critolush & $\mathrm{AR}$ & $95 \%$ & Setting \\
\hline 75 & 632 & 17.7 & 3.2 & 5.6 & $3.53 \times 8.90$ & Family ptanning eltinic \\
\hline 32 & 1444 & 16.2 & 4.7 & 3.4 & $2 \cdot 15 \cdot 5 \cdot 47$ & $\begin{array}{l}\text { Hootdzakelijk paltholagische } \\
\text { wistrijkges }\end{array}$ \\
\hline (6) & 100 & 38 & E & 7.6 & 3.12 .18 .5 & Verwazen patienten \\
\hline 67 & 733 & 51.7 & 15.6 & 3.3 & $2.77 \cdot 3.99$ & $\begin{array}{l}\text { Gean Endo"s in } 2 \text { vroegene uit } \\
\text { strijkjes }\end{array}$ \\
\hline 29 & 100 & 6. & 0 & ON & $=$ & Openwalgende pat. \\
\hline
\end{tabular}

ON: onerirsdig

$O R_{i \text { it }}=5.78[4.74 \cdot 7.05 !$ 
Het is opvallend hoezeer de sameinstelling van de onderzoeksgroepen in deze reeks studies en ook de resultaten van de individuele studies sterk verschillen. Tooh komt uit alle onderzoeken dezelfde tendens naar voren.

\section{Spatel van Ayre versus Extended-tip spatel}

Bij, een vergelijking van 10.690 paren uitstrijkjes werd een relatief risico op afwezigheid van endocervicale cellengevonden van $1.26(95 \% \mathrm{Bl}=1.25-1.27)$ ten nadele van de spatel van Ayre (Bourne e.a. 1976).

\section{Spatel van Ayre versus wattenstok}

In een studie met gepaarde stalen van 100 vrouwen werd telkens $6 \%$ endocervicale cellen-negatieve uitstrijkjes gevonden bij afname met respectievelijk de klassieke Ayre spatel en de wattenstok alleen (Brink e.a. 1989!.

\section{Accu-Pap versus extended-tip spatel}

Stock e.a. vonden geen significant verschil in voorkomen van endocervicale cellen tussen beide technieken in twee reeksen van elk 100 patiënten (Stock e.a. 1988).

\subsubsection{VERGELIJKINGEN TUSSEN GROEPEN VAN VERSCHILLIENDE PATIËNTEN}

Spatel van Ayre versus extended-tip spatel

De drie studies, die op deze vergelijking betrekking hebben, zijn alle van Britse afkomst (tabel 1.14). Hun resultaten liggen alle in dezelfde buurt. Zij wijzen op een betere score voor de extended-tip spatel in het oogsten van endocervicale cellen.

Tabel 1.14: Relatief risico op afwezigheid van endocervicale cellen in uitstrijkjes gemaakt met de spatel van Ayre versus de extended-tip spatel

\begin{tabular}{|c|c|c|c|c|c|c|c|c|c|}
\hline Raf. & $\begin{array}{l}\text { Totoal } \\
\text { adantal }\end{array}$ & $\mathrm{RR}$ & $\begin{array}{l}95 \% \mathrm{BI} \\
\text { (RR) }\end{array}$ & Jarar & Land & $\begin{array}{l}\text { Ge- } \\
\text { palard? }\end{array}$ & $\begin{array}{l}\text { Ran } \\
\text { dom? }\end{array}$ & Trpe & Opmerkingen \\
\hline 27 & 21380 & 1.26 & $\begin{array}{l}1.25 \\
1.26\end{array}$ & 1976 & UK & ja & ja & Armovïcal & . \\
\hline 85 & 1304 & 2.34 & $\begin{array}{l}2.03 \\
2.70\end{array}$ & 1986 & U.⿲丿丨乚 & neam & neen & Lotorner & 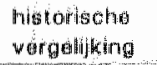 \\
\hline 92 & 4080 & 1.20 & $\begin{array}{l}1.16- \\
1.24\end{array}$ & 1989 & UK & negen & ja & Aytesbury & $\begin{array}{l}\text { crosti-over (4 } \\
\text { mond) }\end{array}$ \\
\hline
\end{tabular}

$\mathrm{OR}_{\mathrm{mwx}}=1.27(95 \% \mathrm{Bl}=1.27-1.27)$

\section{Spatel + Wattenstok versus Extended-tip Spatel alleen}

In drie kleinere studies (Colon e.a. 1983, Deckert e.a. 1988, Hamblin e.a. 1985) werd een groter aantal uitstrijkjes zonder endocervicale cellen gevonden in de spatel + wattenstokuitstrijk. In ển veel grotere studie (Boon e.a. 1989) daarentegen vindt men meer uitstrijkjes zonder endocervicale cellen in de uitstrijkjes gemaakt met de extended-tip spatel. Uiteraard is het mogelijk en zelfs waarschijinlijk dat dit belangrijk verschil tussen studieresultaten door één of andere interactiefactor veroorzalakt 
wordt In een dergelik geval is het poolen wan de resultaten zinioos. Wil hebben het hier dan ook niet gedaan. Overigens is het ienige opvallende verschil tussen de drie kleinere studies en de grote, nasst hun omvang, het land waar zil uitgevoerd werden: de kleinere in de Verenigde Staten, de grote in Nederland.

Tabel 1.15: Relatief risico op afwezigheid van endocervicale cellen in uitstrijkjes gemaakt met de Spatel + Wattenstok versus Extended-tip Spatel uitstrijkjes

\begin{tabular}{|c|c|c|c|c|c|c|c|c|c|}
\hline$P_{1}$ & $\begin{array}{l}\text { Tot: } \\
\text { gant: } \\
\text { unstr: }\end{array}$ & PH & $\begin{array}{l}95 \% \\
81 \\
\text { IRAP }\end{array}$ & Jar & Larnd: & $\begin{array}{l}\text { Ran- } \\
\text { domil- } \\
\text { sation? }\end{array}$ & $\begin{array}{l}\text { Type } \\
\text { aparel } \\
\text { allegen }\end{array}$ & $\begin{array}{l}\text { Typo spateh } \\
\text { gebrule met } \\
\text { de wart }\end{array}$ & $\begin{array}{r}\text { Opmerkingen } \\
:\end{array}$ \\
\hline 65 & 412 & 1.67 & $\begin{array}{l}1.24 \\
2.28\end{array}$ & 1983 & Us & neen & exttip & Ayre & $\begin{array}{l}\text { attear premena- } \\
\text { pauzale vrou- } \\
\text { wen }\end{array}$ \\
\hline $\begin{array}{l}101 \\
\end{array}$ & $654:$ & $1: 32$ & $\begin{array}{l}1.07 \\
102\end{array}$ & 1986 & VS & neten & milex & Avro: & \\
\hline 58 & 262 & 1.22 & $\begin{array}{l}0.83- \\
0.80\end{array}$ & 198 & Vs & 洞 & Ext. Iip & "standaard" & - \\
\hline 26 & 12340 & 0.79 & $\begin{array}{l}0.68 \\
0.91\end{array}$ & 1989 & $\mathrm{Nad}$ & ja & axtilip & axtip & $\begin{array}{l}\text { bevolkingeon. } \\
\text { derzoak }\end{array}$ \\
\hline
\end{tabular}

Spatel versus Spatel + Cytobrush

De combinatieafname oogst in alle studies duidelijk meer endocervicale cellen dan de Spatel alleen (tabel 1.16). Het valt op dat het relatief risico in de drie Nederlandse studies telkens veel groter is dan in de twee Amerikaanse studies.

Tabel 1.16: Relatief risico op afwezigheild van endocervicale cellen in uitstrijkjes gemaakt met een Spatel alleen versus de combinatie van Spatel + Cytobrush

\begin{tabular}{|c|c|c|c|c|c|c|c|c|c|}
\hline Rol. & $\begin{array}{l}\text { Tot. } \\
\text { aralit. } \\
\text { untstr. }\end{array}$ & $\mathrm{AB}$ & $\begin{array}{l}95 \% \mathrm{BI} \\
\text { MARI }\end{array}$ & Jar & Land & $\begin{array}{l}\text { Rando- } \\
\text { misa- } \\
\text { tie? }\end{array}$ & $\begin{array}{l}\text { Ga- } \\
\text { parard? }\end{array}$ & $\begin{array}{l}\text { Tyou spatel } \\
\text { allat }\end{array}$ & $\begin{array}{l}\text { Type spa- } \\
\text { tol bil } \\
\text { Cymobrust }\end{array}$ \\
\hline 21 & 30212 & 8.0 & $\begin{array}{l}6.65 \\
9.62\end{array}$ & 1980 & Ned & - & nean & ext. tip & axt. Hip \\
\hline 26 & 13282 & 11.9 & $\begin{array}{l}8.39 \\
16.99\end{array}$ & 1989 & Nod & + & rueery & ext. fip & ext. tip \\
\hline 74 & 260 & 11.0 & $\begin{array}{l}2.68 \\
46.23\end{array}$ & 1988 & $\mathrm{Ned}$ & + & 释 & extt. tip & ext. tip \\
\hline 58 & 270 & 1.62 & $\begin{array}{l}1.0 n \\
2.63\end{array}$ & 1988 & Vs & + & naen & "standaard" & $\begin{array}{l}\text { "stan } \\
\text { datard" }\end{array}$ \\
\hline 136 & & 3.4 & & 1990 & vs & - & neen & $?$ & $?$ \\
\hline
\end{tabular}

$O P_{m+1}=8.2498 \% \mathrm{BI}=8.14 \cdot 8.35$ 
Kuo e.a. rapporteren alleen de verkregen percentages van een historische vergellfking tussen spatel en spatel + Cytobrushafnames (Kuo e.a. 1990). Hun gegevens zilin dan ook niet in de pooling opgenomen. Het percentage uitstrijkjes zonder endocervicale cellen bedroeg met de Spatel $71 \%$ en met de combinatietechniek $21 \%$. RR $=3.4$.

Wij vonden twee studies, waarin de extended-tip spatel vergeleken wordt met de Cytobrush alleen. Beide studies geven een vergelijkbaar Relatief Risico op afwezigheid van endocervicale cellen, respectievelijk $3.0(95 \% \mathrm{Bl}=0.32-28.35$ ) (Spurrett e.a. 1989) en $2.55(95 \% \mathrm{Bl}=1.53-4.24)$ Vooijs 1988). De gepoolde RR is 2.57 $(95 \% \mathrm{BI}=2.26-2.93)$. Het erg brede betrouwbaarheidsinterval in de eerste studie is te wijten aan een combinatie van een vrij klein aantal onderzochte uitstrijkjes en een erg laag aantal uitstrijkjes zonder endocervicale cellen.

Een reeds vermelde studie op gepaarde uitstrijkjes bij 100 vrouwen geeft $6 / 100$ uitstrijkjes zonder endocervicale cellen in de uitstrijkjes gemaakt met een klassieke Ayre spatel, tegenover $0 / 100$ voor de Cytobrush alleen (Brink e.a. 1989).

\section{Extended-tip spate/ versus Cervexbrush}

In alle gevallen komt de Cervex er als de beste uit met redelijk vergelijkbare relatieve risico's (tabel 1.17 ). In één studie wordt daarbij vermeld dat ook de interdokterviariatie duidelijk afneemt tijdens het gebruik van de Cervex (Laverty e.a. 19891 .

Tabel 1.17: Relatief risico op afwezigheid van endocervicale cellen in uitstrijkjes gemaakt met een Extended-tip spatell versuls de Cervex

\begin{tabular}{|c|c|c|c|c|c|c|c|c|}
\hline Peff. & $\begin{array}{l}\text { Totad } \\
\text { aantal }\end{array}$ & RR & $95 \% \mathrm{BI}$ & Jiarar & Land & Random? & $\begin{array}{l}\text { Ge. } \\
\text { paard? }\end{array}$ & Type spatel \\
\hline 26 & 11767 & 2.12 & $1.75,2.67$ & 1989 & Ned & jia: & naen & "ext.tip" \\
\hline 222 & 14139 & 3.39 & $2.99-3.84$ & 1989 & Ned & neen & neen & "pointed" \\
\hline 223 & 761 & 1.06 & $1.05 \cdot .07$ & 1988 & Ned & ja. & nต่อก & nien wermald \\
\hline 138 & $*$ & 211 & 1.72 .259 & 1989 & Auts: & neen & neen: & "armovisal" \\
\hline
\end{tabular}

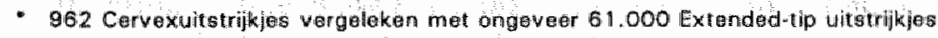
$O R_{\text {rmm }}=2.90195 \% \mathrm{Bl}=2.70 \cdot 3.301$.

Bij een vergelijking van 2 groepen uitstrijkjes gemaakt met de Cervex versus de Ayre spatel ( $n=299+1.315$ ) werd de kwaliteit beoordeeld met als criterium: voldoende plaveiselcellen en endocervicale cellen zonder teveel bijmenging van storend materiaal (Weyler e.a.). Het relatief risico op onvoldoende kwaliteit (spatel/Cervex) $=1.29(95 \% \mathrm{~B} \|=1.15-1.45)$. 
Spatel + Wattenstok versus Cervex

Door dezelfde auteurs worden uitstrijkjes, gemaakt met spatel + wattenstok vergeleken met Cervexuitstrijkjes (Weyler e.a.). Daarbij bedraagt het RA: 1.17 $195 \% \mathrm{BI}=1.04-1.32)$.

Spatel van Ayre versus Multispatula

De Multispatula doet het hier duidelijk beter dan de spatel van Ayre.

Tabel 1.18: Relatief risico op afwezigheid van endocervicale cellen in uitstrijkjes gemaakt met een Spatel van Ayre versus de Multispatula

\begin{tabular}{|c|c|c|c|c|c|c|c|c|c|}
\hline pef. & $\begin{array}{l}\text { Tot. } \\
\text { aant: } \\
\text { viturt. }\end{array}$ & $\mathrm{RH}$ & $\begin{array}{l}26 \% \text { B। } \\
\text { (AR) }\end{array}$ & Jallar & Land & $\begin{array}{l}\text { Nan- } \\
\text { domi- } \\
\text { satio? }\end{array}$ & $\begin{array}{l}\text { Ge: } \\
\text { paarde } \\
\text { afna } \\
\text { mes }\end{array}$ & $\begin{array}{l}\text { Typa } \\
\text { spetial } \\
\therefore \quad:\end{array}$ & $\begin{array}{c}\text { Opmerkingen } \\
\text { (n) }\end{array}$ \\
\hline $165^{*}$ & 710 & 2.74 & $\begin{array}{l}1.80 \\
4.00\end{array}$ & 1984 & UK & ja & 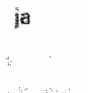 & Avre & $\begin{array}{l}\text { "Welkens earst de } \\
\text { Multispatula } \\
\text { routimepat. }\end{array}$ \\
\hline $165^{*}$ & 450 & 3.32 & $\begin{array}{l}2.49 \\
4.42\end{array}$ & 1984 & UK & jia & meen: & Ayre: & aten zwarnger \\
\hline 166 & 316 & 3.6 & $\begin{array}{l}3.42 \\
3.79\end{array}$ & 1988 & UK & $\mathrm{j}$ & ja & Ayre & $\begin{array}{l}\text { pat. verwazen voor } \\
\text { colposcopis }\end{array}$ \\
\hline $22 *$ & 472 & 1.6 & $\begin{array}{l}1.36 \\
1.88\end{array}$ & 1987 & Borneo & ja & a & Ayre & routine \\
\hline
\end{tabular}

- over de 2 eerste studies wordt in 1 artikel samen gerapporteerd.

$O F_{\text {tat }}=2.64(95 \% B)=2.59-2.691$.

Wattenstok versus Cytobrush, al dan niet in combinatie met een Spatel

Deze vergelijking gebeurde in maar liefst twaalf studies, veruit het grootste aantal dat wij vonden voor een dergelijke vraagstelling (tabel 1.19). In al deze studies komt de Cytobrush er als de beste uit voor wat betreft de oogst aan endocervicale cellen. De RR's gaan van 1 tot 20 . Slechts in twee kleinere studies is de waarde 1 begrepen in het $95 \%$ betrouwbaarheidsinterval. De door ons berekende MantelHaenszelschatting van de gepoolde RR blift vrij stabiel als wij alleen de gerandomiseerde studies in de berekening betrekken (tabel 1.19).

Twee studies met gepaarde uitstrijkjes (Kristensen e.a. 1989b, Trimbos e.a. 1986) werden niet in de pooling betrokken omdat zij uitgevoerd werden bij kleine groepen van erg geselecteerde patiënten.

\section{Spatel + Bulb aspirator versus Spatel + Cytobrush}

Met de Bulb aspirator werden $26 \%$ uitstrijkjes zonder endocervicalie cellen gevonden in een onderzoek op 192 patiënten met bekende pathologie (Selvaggi e.a. 19891. Het relatief risico tegenover de gecombineerde Spatel + Cytobrush-afname is $13.0(95 \% \mathrm{~B})=6.33-26.68)$. 


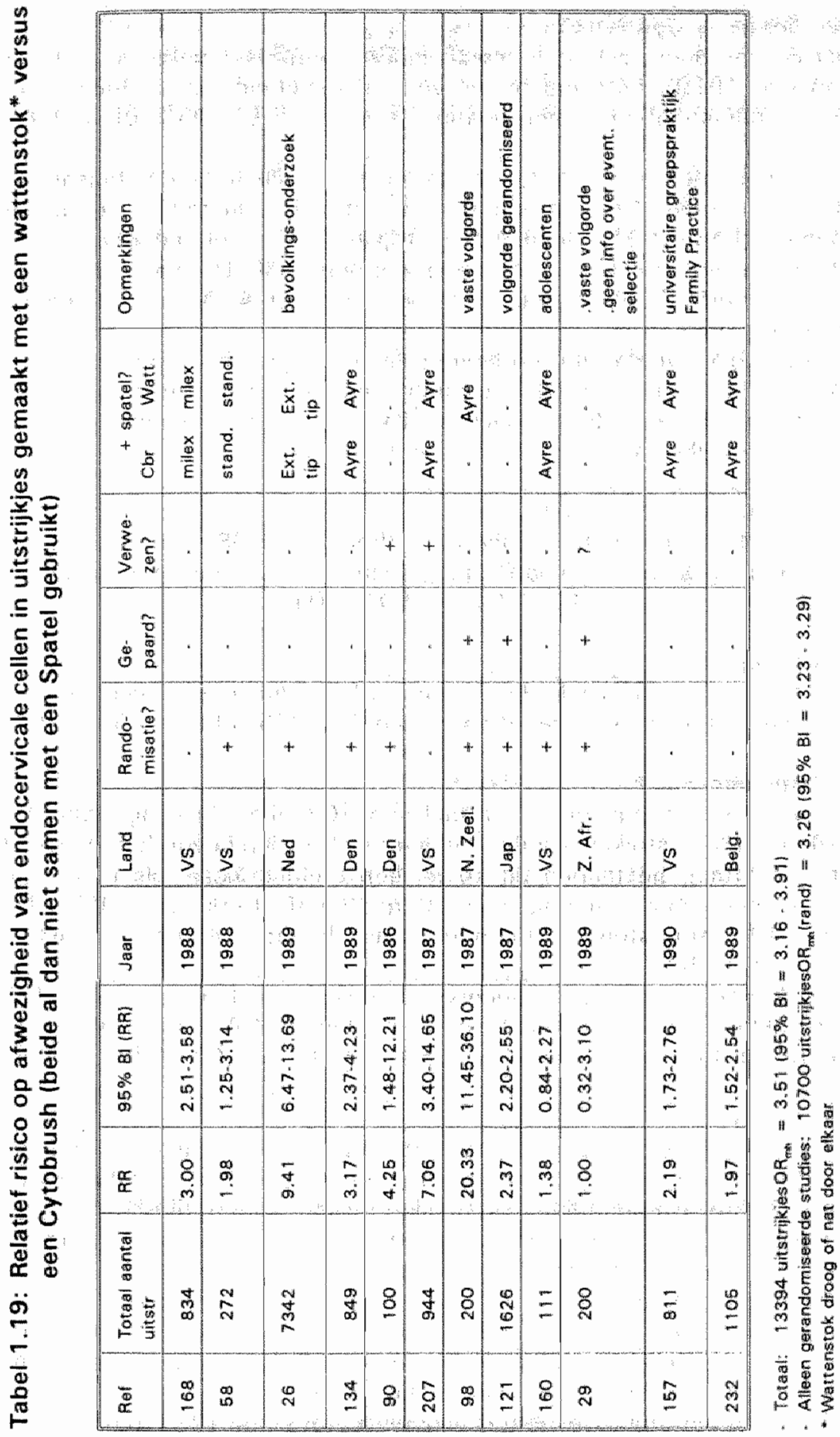




\section{Cervex versus Spatel + Cytobrush}

Uit het onderzoek van Boon, waarin 5 verschillende afnametechnieken vergeleken worden (Boon e.a. 1989), berekenden wi) voor afwezigheid van endocervicale cellen (Cervex/combinatieafname) een relatief risico van $5.62195 \% \mathrm{BI}=3.78$ 8.36).

Dezelfde auteur registreerde tevens de resultaten van 21 Nederlandse huisartsen die eer deel van hun uitstrijkjes met spatel + Cytobrush maakten en een ander deel met de Cervex (Boon 1991). Het aantal uitstrijkjes zonder endocervicale cellen bedroeg in de eerste groep $3 \%$ en in de tweede groep $15 \%$. De maximale spreiding tussen de verschillende artsen was in de tweede groep $41 \%$. Voor de eerste groep wordt dit niet opgegeven.

Hierbij moet opgemerkt worden dat de beide groepen uitstrikjes in verschillende laboratoria onderzocht werden en dat de vitstrijkjes van de eerste groep uit de dagelijkse praktijkvoering stamden, terwijl de vitstrijkjes van de tweede groep in het kader van het bevolkingsonderzoek afgenomen werden.

\section{Cytopick versus Spatel + Cytobrush}

Uit het reeds vermelde onderzoek van Boon e.a. (Boon e.a. 1989) berekenden wij voor de verhouding Cytopick/combinatieafname een relatief risico op afwezigheid van endocervicale cellen van $2.64(95 \% \mathrm{BI}=1.73-4.04)$.

\section{Cervex versus Crtopick}

Nogmaals uit hetzelfde onderzoek (Boon e.a. 1989) berekenden wij voor de verhouding Cervex/Cytopick een relatief risico van $2.13(95 \% \mathrm{BI}=1.59-2.85)$.

\section{Andere afnametechnieken}

In een studie van Dotters e.a. op een totaal van 403 uitstrijkjes bij zwangere vrouwen werden $1.4 \%$ uitstrijkjes zonder endocervicale cellen gevonden, gemaakt met een specialle brush, bestaande uit zowel een endocervicaal als een ectocervicaal deel in een hoek van ongeveer 90 graden (Dotters e.a. 1988). Dit percentage was $19 \%$ in uitstrijkjes, afgenomen met de spatel en de wattenstok. Het relatief risico is 13.57 .

Een significant hoger percentage endocervicale cellen werd gevonden in 138 uitstrijkjes gemaakt met een Armourspotel bij vergelijking met 273 Ayre-uitstrijkjes (Wachtel e.a. 1974). RR (Ayre/Armour) $=1.55(95 \% \mathrm{BI}=1.07-2.261$.

\subsubsection{PICK UP RATES}

Het zou van weinig wiysheid getuiger om besluiten over de relatieve waarde van verschillende afnametechnieken alleen te baseren op een overzicht van de pick-up rates (Light e.a. 1984). De onderlinge verschillen tussen landen, beroepsgroepen en patiëntenpopulaties zijn daarvoor te groot. Dit geldt zowel voor pathologie als voor het al dan niet vinden van celtypen.

Nadat wij uitvoerig gerapporteerd hebben over de vergelijkende studies, kan een overzicht van alle gevonden aantallen en percentages echter een nuttige aanvulling zijn. Het feit dat in dit overzicht nauwelijks gegevens uit open, niet vergelijkende studies opgeromen zijn, verhoogt nog zijn bruikbaarheid.

Dit onderdeel van het literatuuroverzicht is bijgewerkt tot einde 1989 in plaats van tot einde 1990 (tabel 1.201 . 
Tabel 1.20: Percentage uitstrijkjes met endocervicale cellen volgens de gebruikte afnametechniek ( 32 studies)

\begin{tabular}{|c|c|c|c|c|c|}
\hline Mathade & Rief. & $\begin{array}{l}\text { Aant. } \\
\text { uitstr }\end{array}$ & $\begin{array}{l}\text { Perto. } \\
\text { Endo }+\end{array}$ & Land & Opnarkingen \\
\hline Cytobrush wash out & 98 & 100 & 100.0 & $\mathrm{NZZ}$ & \\
\hline Bayne Pap brush & 68 & 204 & 98.6 & VS & Alleen zwangeren \\
\hline Critopick & 26 & 3406 & 97.9 & Ned & . \\
\hline $\begin{array}{l}\text { Spatel + Cytobrush* } \\
\text { Totaal }\end{array}$ & $\begin{array}{c}58 \\
207 \\
2 \pi \\
192 \\
134 \\
26 \\
168 \\
47 \\
160 \\
74\end{array}$ & $\begin{array}{c}140 \\
479 \\
5716 \\
90 \\
418 \\
4142 \\
610 \\
616 \\
51 \\
130 \\
123192 \\
\end{array}$ & $\begin{array}{l}84.3 \\
98.3 \\
98.0 \\
97.0 \\
88.0 \\
99.2 \\
83.0 \\
88.6 \\
79.0 \\
98.0 \\
96.7\end{array}$ & $\begin{array}{l}\text { VS } \\
\text { WS } \\
\text { Ned } \\
\text { VS } \\
\text { Dan } \\
\text { Ned } \\
\text { VS } \\
\text { WI } \\
\text { Wed }\end{array}$ & $\begin{array}{l}\text { Verwezen patiênten } \\
\text { I Uitstrijklstier } \\
\text { "Bhigh-risk patienten" }\end{array}$ \\
\hline $\begin{array}{l}\text { Cervex } \\
\text { Totaal: }\end{array}$ & $\begin{array}{c}26 \\
138 \\
223 \\
73 \\
222\end{array}$ & $\begin{array}{c}2627 \\
962 \\
450 \\
299 \\
7297 \\
11635\end{array}$ & $\begin{array}{l}95.6 \\
91.3 \\
93.3 \\
53.5 \\
93.5 \\
92.8 \\
\end{array}$ & $\begin{array}{l}\text { Ned } \\
\text { Austr } \\
\text { Nad } \\
\text { Belg } \\
\text { Ned }\end{array}$ & 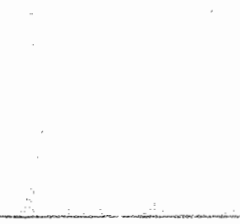 \\
\hline $\begin{array}{l}\text { Cytobrush allean } \\
\text { Totaal: }\end{array}$ & $\begin{array}{l}223 \\
90 \\
98 \\
121 \\
212 \\
203\end{array}$ & $\begin{array}{c}930 \\
50 \\
100 \\
813 \\
30 \\
100 \\
2023\end{array}$ & $\begin{array}{l}97.6 \\
92.0 \\
97.0 \\
78.2 \\
90.0 \\
99.0 \\
89.7\end{array}$ & $\begin{array}{l}\text { Ned } \\
\text { Den } \\
\text { N.ZI } \\
\text { Jap } \\
\text { Nad } \\
\text { WS }\end{array}$ & verwezen patiënten \\
\hline $\begin{array}{l}\text { Multispatula } \\
\text { Totarall: }\end{array}$ & $\begin{array}{l}165 \\
165 \\
166 \\
221\end{array}$ & $\begin{array}{l}355 \\
226 \\
158 \\
236 \\
974\end{array}$ & $\begin{array}{l}88.3 \\
81.0 \\
87.3 \\
79.7 \\
84.3\end{array}$ & $\begin{array}{l}\text { UK } \\
\text { UK } \\
\text { UKK } \\
\text { Boirned }\end{array}$ & \\
\hline Accupap & 206 & 100 & $84: 0$ & ws & \\
\hline
\end{tabular}

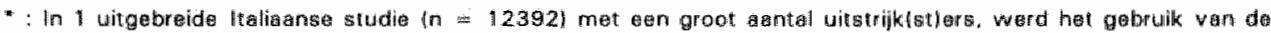
Cytobrusih aangeraden ("recommended"). Er werden andocervicalle cellan alangetrofion in $78 \%$ der uitstrijkjes. Er werd echter riet geregistreard welko alnametechniek uiteindelijk gebruikt werd. Deze studie ward in dit overzictit niet opgenamem. Ails wij dat wel doem en de gegevens varrakenen in de grogip uitstrijkjes gemaent met Spatel 4 Cytobrush, datil het a antal utstrijkjes met endocerwicale cellen to $87.6 \%$. 
verwoig tabel 1:20

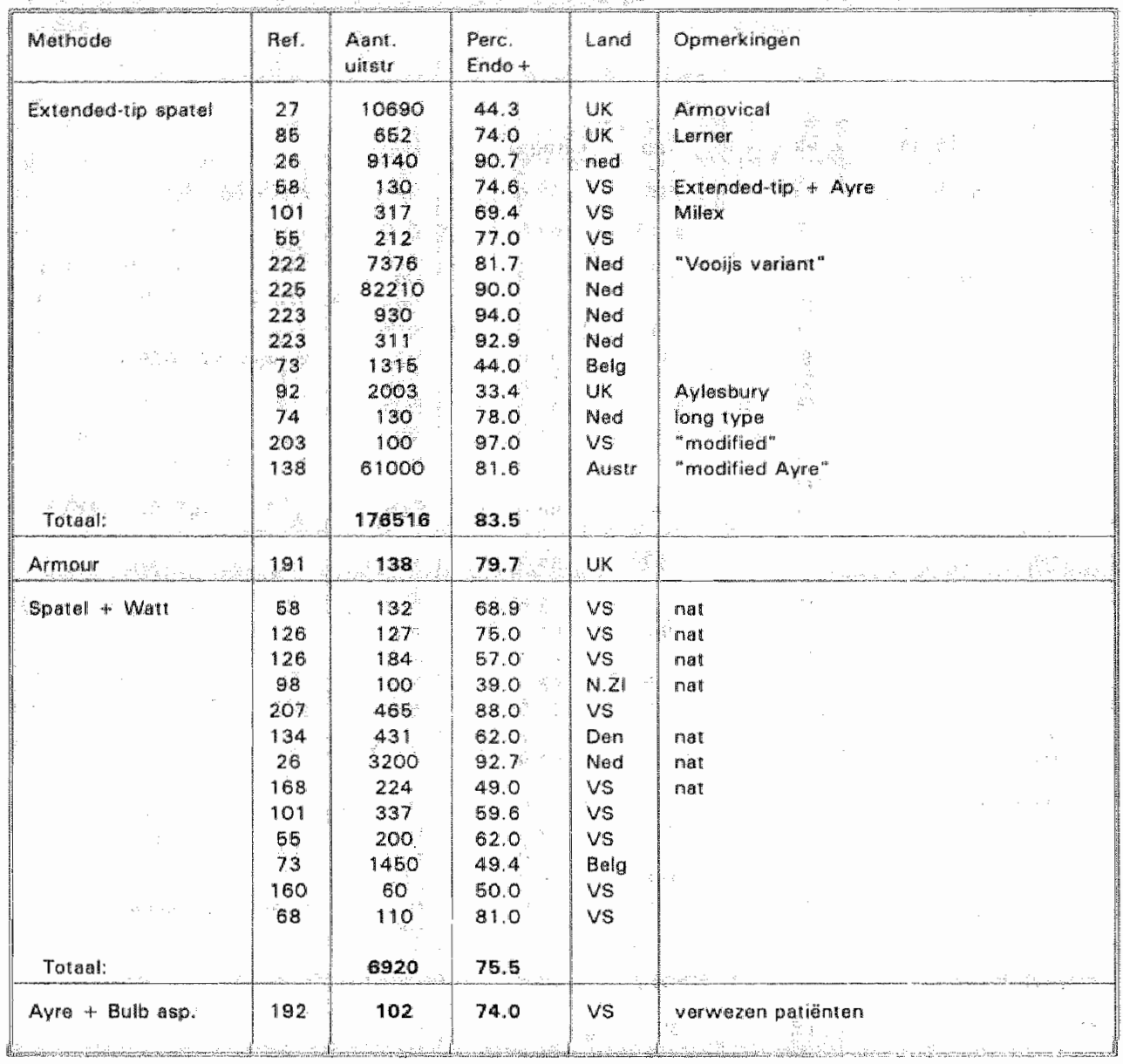


vervolg tabel 1.20

\begin{tabular}{|c|c|c|c|c|c|}
\hline Meithode: & Ref. & $\begin{array}{l}\text { Aant } \\
\text { uitstr }\end{array}$ & $\begin{array}{l}\text { Perc. } \\
\text { Endo }+\end{array}$ & Land & Opmerkingen \\
\hline $\begin{array}{l}\text { Spatel war Ayre } \\
\text { Totaal: }\end{array}$ & $\begin{array}{c}165 \\
27 \\
90 \\
21 \\
92 \\
165 \\
166 \\
221 \\
\\
206 \\
85 \\
191\end{array}$ & $\begin{array}{c}355 \\
10690 \\
652 \\
24496 \\
2077 \\
226 \\
158 \\
236 \\
100 \\
652 \\
273 \\
399 \| 4\end{array}$ & $\begin{array}{l}68.0 \\
29.6 \\
39.0 \\
84.0 \\
20.4 \\
37.0 \\
54.4 \\
66.9 \\
88.0 \\
39.0 \\
68.5 \\
63.9\end{array}$ & $\begin{array}{l}\text { UK } \\
\text { UK } \\
\text { Den } \\
\text { Nad } \\
\text { UK } \\
\text { UK } \\
\text { UK } \\
\text { Bol- } \\
\text { neo } \\
\text { VS } \\
\text { UK } \\
\text { UK }\end{array}$ & 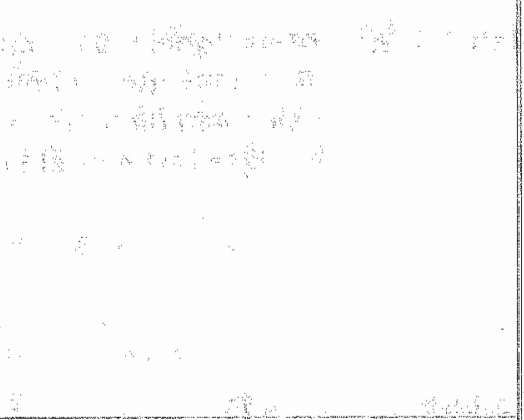 \\
\hline $\begin{array}{l}\text { Watt. illeen } \\
\text { Toteat: }\end{array}$ & $\begin{array}{c}212 \\
121 \\
90\end{array}$ & $\begin{array}{c}30 \\
813 \\
50 \\
893\end{array}$ & $\begin{array}{l}30.0 \\
48.5 \\
66.0 \\
48.18\end{array}$ & $\begin{array}{l}\text { Ned } \\
\text { Jap } \\
\text { Den }\end{array}$ & verwezon pat. \\
\hline
\end{tabular}

Waar voldoende gegevens beschikbaar waren hebben wij uit de in tabel 1,20 vermelde studies de oogst aan endocervicale cellen per afnamemethode vergeleken in vier subgroepen: zwangere vrouwen, postmenopauzale vrouwen, jongeren ( $\leq$ 35 jaar) en postradiotherapie patiënten. De Bayne Pap Brush (voor postmenopauzale vrouwen) en de spatel + Cytobrushcombinatiemethode (voor de drie andere subgroepen) komen er als de beste techniek uit (tabel 1.21).

Tabel 1.21: Gemiddeld percentage* uitstrijkjes met endocervicale cellen (pick-up rate) gemaakt volgens verschillende afnamemethoden in vier patiëntengroepen. Aantal studies tussen haakjes.

\begin{tabular}{|c|c|c|c|c|}
\hline & $\begin{array}{l}\text { allen } 2 \text { ven durge } \\
\text { ran }\end{array}$ & post menopauzo & $3 \mathrm{sij}$ & $\begin{array}{l}\text { me radionting- } \\
\text { repio }\end{array}$ \\
\hline Extended-tip & $42(1)$ & 4111 & $40: 11$ & - \\
\hline Spent * Wall & 7413 & $57(5)$ & $57 \mid 11)$ & $82\|1\|$ \\
\hline Spatel + Cytobrush & $100(2)$ & - & $99(11)$ & $87\|1\|$ \\
\hline Spatel + aspirator & $40\{1\}$ & 75111 & . & . \\
\hline Bavme Pap brush & $986(1)$ & $83(4)$ & $\therefore$ & $\therefore$ \\
\hline Spatel van Ayre: & $56.7\{1\}$ & $\therefore$ & $34(1)$ & - \\
\hline Cytobrush allem & $\therefore$ & . & $62(1)$ & . \\
\hline Watt alleen & - & & 27111 & $:$ \\
\hline
\end{tabular}

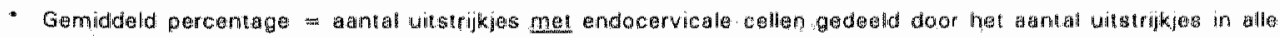
betrokken studies 
3.2 .4 SAMENVATTING VAN DE RESULTATEN

De resultaten van de vergelijkende studies uit sectie 3.2 worden samengevat in tabel 1.22 .

Tabel 1.22: Afwezigheild van endocervicale cellen uin uitstrijkjes gemaakt met verschillende technieken. Gerapporteerd wordt het (gepoold) relatief risico van de techniek in de $y$-as versus de techniek in de $x$-as (tussen haakjes het aantal studies waarop het relatief risico gebaseerd is)

\begin{tabular}{|c|c|c|c|c|c|c|c|c|}
\hline & Aur & Ext. tip & Watt. & $\begin{array}{l}\text { Crito- } \\
\text { brush }\end{array}$ & Cerwax & $\begin{array}{l}\text { Mufti: } \\
\text { spatula }\end{array}$ & $\begin{array}{l}\text { Aspira. } \\
\text { tar }\end{array}$ & $\begin{array}{l}\text { Cyto } \\
\text { pick }\end{array}$ \\
\hline Alro & . & $\begin{array}{l}1.27 \\
137\end{array}$ & $\begin{array}{l}1.0 \\
(1)\end{array}$ & ON & . & $\begin{array}{l}2.64 \\
(4)\end{array}$ & - & - \\
\hline Extended-tip & $\begin{array}{l}0.79 \\
|3|\end{array}$ & - & $\begin{array}{l}41 \\
44\end{array}$ & $\begin{array}{l}8.24^{*} \\
\{4\} \\
2.5 .7 * \\
(2)\end{array}$ & $\begin{array}{l}2.90 \\
44\end{array}$ & . & - & . \\
\hline Watrenstak & $\begin{array}{l}1.0 \\
111\end{array}$ & (4) & . & $\begin{array}{l}3.61 \\
(12)\end{array}$ & $\begin{array}{l}1.17 \\
111\end{array}$ & - & . & . \\
\hline Cytobrueh & 0 & $\begin{array}{l}0.12 \\
(4) \\
0.35 \\
(2)^{*}\end{array}$ & $\begin{array}{l}0.28 \\
(12) \\
\therefore\end{array}$ & $\therefore$ & $\begin{array}{l}0.19 \\
11\end{array}$ & $\cdots$ & $\begin{array}{l}0.08 \\
111\end{array}$ & $\begin{array}{l}0.38 \\
111 \\
\therefore\end{array}$ \\
\hline Cenvex & $\therefore$ & $\begin{array}{l}0.34 \\
(4)\end{array}$ & $\begin{array}{l}0.85 \\
111\end{array}$ & $\begin{array}{c}5.62 \\
(1) \\
\end{array}$ & - & . & - & $\begin{array}{l}2.13 \\
111 \\
1\end{array}$ \\
\hline Multispatula & $\begin{array}{l}0.38 \\
(4)\end{array}$ & . & - & - & “ & - & - & - \\
\hline Aspirator & $\vdots$ & $\because$ & 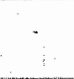 & $\begin{array}{l}13.0 \\
(1)\end{array}$ & 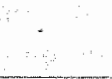 & $\begin{array}{l}\vdots \because \\
\vdots \\
\vdots\end{array}$ & $\because$ & 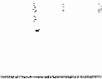 \\
\hline Crtopick & - & - & . & $\begin{array}{l}2.64 \\
111\end{array}$ & $\begin{array}{l}0.47 \\
011\end{array}$ & $\therefore$ & : & - \\
\hline
\end{tabular}

- Cyobrush in combinatio met spatel

* Cymobruen alleen

** $=6 / 0$ on ornimdig

* Gean pooling omwille vam anwijzingen voor heterogentedt

\subsection{Plaveiselcellen}

\subsubsection{GEPAARDE UITSTRLIKJESS}

Het voorkomen van plaveiselcellen in bijna 1000 paren uitstrijkjes, gemaakt met de Cytobrush en met een wattenstok werd vergeleken (Kawaguchi e.a. 1987). Alle patiënten waren verwezen voor evaluatie na een voorafgaand afwijkend uitstrijkje. Er waren $0.4 \%$ uitstrijkjes zonder plaveiselcellen gemaakt met de Cytobrush en $1 \%$ gemaakt met de wattenstok. Het relatief risico op afwezigheid van plaveiselcellen (watt/Cbr) is $2.5(95 \% \mathrm{Bl}=0.79-8.00)$. 
Doornewaard en van der Graaf vonden bij een dubbele afname van 733 pa-tienten onbevredigende uitstrijkjes, "due to a low content of squalmous cells" in 17.5\% van de Cytobrushuitstrijkjes en in $4.4 \%$ van de spateluitstrijkjes (RR $=4.0 \% 95 \%$ $\mathrm{Bl}=2.75-5.811$. Bij de combinatie-ütstrijkjes blijven er nog $1.6 \%$ uitstrijkjes zonder plaveiselcellen (Doornewaard e.a. 1990 ).

Zelf vonden wij op 444 hoofdzakelijk pathologische uitstrijkjes, gemaakt met een combinatie spatel + Cytobrush geen plaveiselcellen terug in $6.1 \%$ van de Cyto brushuitstrijken, in $3.2 \%$ van de spateluitstrijken (extended-tip) en in 1 geval van de combinatie-uitstrijken (Buntinx e.a. 1991). De RR (Cbr/spatel) $=1.93(95 \%$ B $=1.03-3.63 \%$

De grote verschillen in percentages uitstrijkjes zonder plaveiselcellen zijn hierbij opvallend. De RR's zijn echter vrij stabiel.

\subsubsection{VERGELIIKINGEN TUSSEN GROEPEN VAN VERSCHILLENDE PATIËNTEN}

Vier auteurs vergeleken het voorkomen van plaveiselcellen in uitstrijkjes afgeno. men met verschillende afname-instrumenten (tabel 1.23 ).

Bij gebruik van de Cytobrush blijkt een gelijktijdig afgenomen spateluitstrijkje noodzakelijk om te vermijden dat plaveiselcellen in thet uitstrijkje ontbreken, hetgeen zou suggereren dat de overgangszone gemist werd.

Tabel 1.23: Afwezigheid van plaveiselcellen bij verschillende afnametechnieken. Het relatief risico is berekend als het percentage uitstrijkjes zonder plaveiselcellen gemaakt met de eerste methode. gedeeld door het overeenkomend percentage uitstrijkjes gemaakt met de tweede methode.

\begin{tabular}{|c|c|c|c|c|c|c|c|}
\hline Ref. & $\begin{array}{l}\text { Totaal } \\
\text { andrt. } \\
\text { uitstr. }\end{array}$ & $\begin{array}{l}\text { Gepaard? } \\
\end{array}$ & $\begin{array}{l}\text { eerste } \\
\text { methode }\end{array}$ & $\begin{array}{l}\text { twerede } \\
\text { mothodie }\end{array}$ & $\mathrm{RR}$ & $95 \%$ & Opmerkingen \\
\hline 121 & 98.6 & + & Cytobrusty & Watt & 0.40 & $0.13 \cdots 1.27$ & Pouting \\
\hline 232 & 1105 & 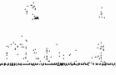 & Cytabrusti & $\begin{array}{l}\text { Spat } \\
\text { Watt }\end{array}$ & $\begin{array}{l}3.86 \\
\vdots\end{array}$ & $2.66-5.5 .8$ & $\begin{array}{l}\text { Roultine : } \\
\end{array}$ \\
\hline 32 & 880 & + & Cyrobrusti & Sputal & 1.93 & 103.3 .63 & $\begin{array}{l}\text { Vooral afwijkonde } \\
\text { fuit Bnrijkjes }\end{array}$ \\
\hline 67 & $\begin{array}{r}1466 \\
8 \\
\end{array}$ & + & Civiobrush & $\begin{array}{c}\text { Spraten } \\
\therefore\end{array}$ & $4.00^{\circ}$ & $2.75 \cdot 6.81$ & 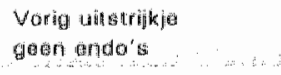 \\
\hline 32 & 880 & + & Cyiobrush & $\begin{array}{l}\text { Spatell + } \\
\text { Cylobrustit }\end{array}$ & 2.08 & $1.09 \cdot 3.97$ & $\begin{array}{l}\text { Vourbl at wilkondo } \\
\text { Wilstrikjes }\end{array}$ \\
\hline 67 & 1465 & + & Cvtobrush & $\begin{array}{l}\text { Spatal } \\
\text { Crtobrust }\end{array}$ & $10.7^{\circ}$ & 5.96 .19 .10 & $\begin{array}{l}\text { Vorig uitstrijkje } \\
\text { goom ando: }\end{array}$ \\
\hline
\end{tabular}

- "unsatisfactory due to a low content of squamous apithelial celts"

\subsection{Onkosten bij verschillende afnamemethoden}

De vermelde onkosten voor materiaal zijn afgeronde prijzen zoals in 1991 gebruike lijk in Vlaanderen. Zij worden hier slechts bij wijze van indicatie gegeven en ook in guldens vermeld. 
Gecombineerde spatel

$\begin{array}{rl}0.85 \mathrm{Bf} & 0.05 \mathrm{fl} \\ 9.90 \mathrm{Bf} & 0.55 \mathrm{fl} \\ 52.00 \mathrm{Bf} & 2.80 \mathrm{fl} \\ 0.38 \mathrm{Bf} & 0.02 \mathrm{fl}\end{array}$

\subsection{Samenvating}

Spatel van Ayre

Dit is een der oudste instrumenten voor het maken van cervixuitstrijkjes. Er zijn weinig problemen voor wat betreft de ectocervicale afname, maar men mist te vaak de endocervicale cellen en (dus) de overgangszone. Het gebruik van de spatel van Ayre of het ermee overeenkomende stompe uiteinde van een gecombineerde spatel is zinvol in combinatie met een andere, op de endocervix gerichte techniek.

\section{Extended-tip spatel}

Deze doet het, zowel wat betreft de oogst aan endocervicale cellen als het vinden van pathologie, beter dan de spatel van Ayre, maar minder goed dan nieuwere technieken als de spatel-Cytobrush combinatie of de Cervex.

\section{Wattenstok}

De oogst aan endocervicale cellen is vergelijkbar met die van de extended-tip spatel, Er bestaat een groot aantal studies ter vergelijking met de Cytobrush. Deze vallen allemaal in het voordeel van deze laatste uit, zowel voor de oogst aan endocervicale cellen, respectievelijk plaveiselcellen, als voor het vinden van pathologie (de beide laatste echter niet significant). Het lijkt erop dat tenminste deze discussie als beslecht kan beschouwd worden. Er blijft uiteraard wel nog het prijsverschil ten nadele van de Cytobrush.

\section{Cytobrush}

De Cytobrush en de combinatie van spatel + Cytobrush komen in alle vergelijkingen met andere instrumenten als opvallend sterkste uit de bus voor wat betreft de oogist aan endocervicale cellen. Voor het vinden van pathologie blijkt de combinatie van spatel en Cytobrush het meest efficiënt. De Cytobrush alleen doet het daarbij slechter dan de spatel; dit geldt ook voor het vinden van plaveiselcellen.

\section{Cervex}

Het aantal vergelijkende studies met dit apparaatje neemt toe. Voorlopig plaatst dit instrument zich achter de Spatel-Cytobrush combinatie en voor de meeste andere technieken. Uiteraard zall ook de hoge prijs hier een rol spelen.

\section{Andere afnametechnieken}

Er lijken momenteel geen medische redenen te bestaan voor het invoeren van Multispatula.Armour spatula, Aspirator of Cytopick. 


\section{Invloed van de afstrijktechniek}

Rubio e.a. gingen het effect na van verschillende afstrijkprocedures op aantal en verdeling der cellen. Zil gebrulkten daarvoor dezelfde in vitro bereide samenstel. lingen van kankercellen in een slijmoplossing, die in de vorige paragrafen reeds ter sprake kwamen.

In een onderzoek bij houten spateluitstrijken (Rubio e.a. 1980c) wordt een groter aantal cellen gevonden bij uitstrijken met een draaibeweging tegen de klok in dan met de klok mee, met parallelle streken en viteindefijk met een zig-zagbeweging. Overeenkomstige resultaten worden gevonden bij het afstrijken van aitstrilkjes, gemaakt met de plastic spatel (Rubio e.a. 1980 ) en met de wattenstok (Rubio e.a. 1980d).

Bij flink aandrukken tijdens het afstrijken worden er $13 \%$ meer cellen op de glaasjes gevonden dan als er minder druk uitgeoefend wordt (Rubio e.a. 1983).

\section{Invloed van de fixatietechniek}

Reeds Papanicolaou en Traut stelden in hun eerste publicatie (Papanicolaou e.a. 1941) dat het uitstrijkje meteen gefixeerd dient te worden. Veel auteurs na hen hebben de snelheld van fixatie benadrukt (Richart 1979, Rubio 1981, Steiner 1989, Zuna 1984). Uitstrijkjes drogen zeer snel aan de lucht. Wanneer dat ge. beurt, treden cellulaire artefacten op. de kleuring wordt onvoldoende intens, de tekening vaag en afwijkende cellen kunnen gemaskeerd worden (Rubio 1981). Wel kan een Cytobrush met slijm rustig tien minuten blijven liggen vóor hij op het objectgaasje afgestreken wordt (Boon 1989). De W.H.O. vermeldt in haar Technical Guidelines de mogelijkheid van drogen aan de lucht als een goedkope fixatie. techniek. Dan moet het uitstrijkje in het laboratorium echter gerehydrateerd worden met $50 \%$ Glycerol (Anoniem 1988). Wij konden echter geen enkele andere auteur vinden die deze handetwijze adviseert.

Voor de fixatie wordt gebruik gemaakt van onderdompeling in een ether alcoholoplossing of van het bespuiten met speciaal daartoe bereide fixatiesprays (Merckofix, Cytofix,...) of haarspray. Dit laatste gebeurt vooral om economische redenen. Jit een vergelijkende studie blijkt dat het gebruik van haarspray aanleiding geeft tot het frekwenter voorkomen van intranucleaire vacuolen in endocervicale en metaplastische cellen: $33 / 55$ bij haarsprayfixatie en $4 / 55$ bij Merckofix-fixatie (Holm e.a. 1988). In een (beperkte) reeks wan 30 paren alwijkende uitstrijkjes konden zij echter geen significante relatie aantonen met het aantal vals negatieve vitstrijkjes.

Uit een gepubliceerde reactie (Affandi 1989) en het antwoord daarop van Holm. blijkt dat de beschreven artefacten weer verdwijnen als men de gefixeerde en ingestuurde plaatjes een nacht laat staan in een oplossing van $95 \%$ ethylalcohol.

De ideale afstand tussen fixatief en glaasje bif het fixeren met spray is zorgvuldig onderzocht (Holmquist 1978): Deze afstand wisselt enigszins volgens het gebruik- 
te produkt maar ligt voor de geteste produkten tussen 25-30 cm. Dit betekent dat veel uitstrijk(st)ers wellicht vanaf te korte afstand fixeren.

Als de afstand groter wordt. is er kans op onvolledige fixatie en witdrogen aan de lucht. Als de afstand kleiner wordt, worden cellen door de druk soms weggebla. zen. Zij kunnen ook bevriezen en daardoor beschadigd raken. De temperatuur van de spray op het ogenblijk van het bespuiten is immers zeer laag (Richart 1979). Er dient loodrecht op het plaatje gespoten te worden.

Een auteur vermeldt het voorkomen van schimmelovergroel als de glaasjes in de houder weggesloten worden, terwijl zij nog niet volledig gedroogd zijn (Craig 19851

In geval van fixatie in een ether-alcoholoplosssing mogen nooit glaasjes van verschillende patiënten in eenzelfde container bewaard worden. Cellen van het ene glaasje kunnert loskomen en zich achteraf op een ander glaasje vasthechten (Rubio e.a. 1974\%. Dit kan zelfs gebeuren als eenzelfde oplossing ina elkaar gebruikt wordt voor verschillende patiënten, tenzij de oplossing tussendoor gefilterd wordt.

\section{Invloed van de uitstrijk(st)er}

Er werd nagegaan in welke mate de discipline, de uitstrijkervaring en de individuele omstandigheden van de uitstrijk(st)er de kwaliteit van de vervaardigde uitstrijkjes beinvloeden:

\subsection{Discipline}

In verschillende studies wordt het verband nagegaan tussen de discipline van de uilstrijkster en éen of meerdere kwaliteitsindicatoren. Bij de interpretatie hiervan stellen zich echter een aantal problemen. Zo zijn op verschillende plaatsen vaak. heel verschillende disciplines bij de afname van cervixuiltstrijkjes betrokken, de preciese rol van een beroepsgroep verschilt vaak sterk op verschillende plaatsen in de wereld (zo zijn Europese huisartsen niet echt vergelijkbaar met Amerikaanse family physicians) en de geregistreerde indicatoren verschillen sterk van de ene studie tot de andere. Met dit in het achterhoofd hebben wij toch geprobeerd in deze doolhof een weg te zoeken.

\section{Endocervicale cellen}

Wij vonden drie studies, waarin de prestaties van huisartsen en gynaecologen vergeleken worden. In een Amerikaanse studie werden (Reissman 1988) endocervicale cellen gevonden in $50 \%$ van de uitstrijkjes gemaakt door family physicians en in $36 \%$ van de vitstrijkjes, gemaakt door gynaecologen vit hetzelfde centrum ( $p \leq 0.001)$. In een eigen random steekproef van $2 \times 100$ uitstrijkjes bij vrouwer uit éen gemeente (Buntinx e.a. 1984) vonden wij endocervicale cellen in 76 gevallen, uitgestreken door huisartsen en in 61 gevallen, uitgestreken door gynaecologen ( $p=0.022$ ). In een andere Belgische studie (VUB Kankerpreventie 1987) werden uitstrijkjes vergeleken van huisartsen en gynaecologen die samenwerken met één laboratorium. Endocervicale cellen ontbraken in $16 \%$ van de huisartsenuilstrijkjes en in $18 \%$ van de gynaecologenuitstrijkjes. Meer gedetailleerde cijfers zijn niet ter beschikking. 
In drie Amerikaanse studies worden de resultaten vergeleken van gevestigde artsen met die van artsen in opleiding. Telkens vindt men bil gevestigde artsen iets vaker endocervicale cellen. In twee studies is het verschil echter niet significant (Ayre 1947. Kirk e.a. 19811, terwill in de derde studie bij 111 adolescenten alleen percentages gerapporteerd worden, zodat het onmogelijk is het verschil te toetsen (Neinstein e.a. 1989).

Recent werd in een Nederlandse huisartspraktijk (Grootenhuis e. a. 1989) de afwezigheid van endocervicale cellen vergeleken in uitstrijkjes gemaakt door huisartsen $(n=46)$ en door praktijkassistenten $(n=56)$. Er kon geen verschil aangetoond worden. Het percentage uitstrijkjes zonder endocervicale cellen bedroeg respectievelijk $8 \%(95 \% \mathrm{Bl}=0-16)$ en $5 \%(95 \% \mathrm{Bl}=0-11)$.

In een aantal studies uit verschillende landen worden verrichtingen van artsen uit de curatieve sector vergeleken met die van screen/stlers in het kader van het bevolkingsonderzoek. Meestal gaat het hierbij om paramedici. Artsen uit de curatieve sector in Nijmegen bleken in de periode 1975-1982 vitstrijkjes te produceren met $90.2 \%$ endocervicale en/of metaplastische cellen tegen $85.3 \%$ voor de screensters van het bevolkingsonderzoek (van Veen 1984). In alle andere gevallen doen de screen(st)ers van het bevolkingsonderzoek het significant beter (Cecchini e.a. 1989, Centrum voor Kankerpreventie UIA, van Veen 1984, Boon e.a. 1985).

\section{Fixatie}

In een Belgische studie (Centrum voor Kankerpreventie UIA) wordt gesignaleerd dat het aantal slecht gefixeerde uitstrijkjes iets hoger zou liggen bij uitstrijkjes, gemaakt door een "wijkvreemde equipe" $(0.2 \%)$ dan bij de huisartsen-uitstrijkjes $10.1 \%)$. (p<0.001).

\section{Pathologie}

In dezelfde studie kon geen statistisch significant verschil aangetoond worden tussen de oogst aan afwijkende uitstrijkjes, gemaakt door een wijkvreemde equipe en door huisartsen.

Kirk en Boon vonden in 1981 een relatief risico van 1.65 als verhouding van het: percentage histologisch bevestigde pathologische uitstrijkjes, afgenomen door huisartsen ten opzichte van de uitstrijkjes uit het bevolkingsonderzoek, bij een afkappunt op ernstige dysplasie. Het verschil bleef constant na opsplitsing volgens type gemeente (Kirk e.a. 1981). In 1987 werd bij een afkappunt op C.I.S. een relatief risico van 5.9 gevonden (Boon e.a. 1987). Hierbij dient men rekening te houden met een verhoudingsgewijs hoger aantal symptomatische patiënten in de curatieve sectar dan bij het bevolkingsonderzoek. 
Tabel 1.24: Pathologie gevonden bij cervixscreening door huisartsen en in het kader van het bevolkingsonderzoek:

\begin{tabular}{|c|c|c|c|c|c|c|c|c|}
\hline Mef: & $\begin{array}{l}\text { Prathologitio } \\
\text { ertheofiumi }\end{array}$ & Wol Wist of pant & 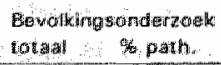 & cand & ph & $95 \% 0$ & $\mathrm{cha}^{2}$ & $p$ \\
\hline 46 & 撕的 & $7080 \quad 470$ & $1709 \quad 430$ & Beil & 1.09 & $\begin{array}{l}0.67 \\
1.24\end{array}$ & 0.34 & 0.53 \\
\hline 46 & Wullits & $7020: \quad 0.90$ & $=1799 \cdot 0.30$ & Bet & 1.67 & $\begin{array}{l}1.04 \\
2.00\end{array}$ & 1.32 & 0.25 \\
\hline 125 & $\| \mathrm{b}$ & $910950 \quad 0.33$ & $57132 \quad 0.20$ & Nent & 1.35 & $\begin{array}{l}1.49 \\
1.33 \\
\end{array}$ & 21.52 & $<0.01$ \\
\hline 17 & Cls. & 2.24 & $28,235 \quad 0.36$ & had & 5.89 & $\begin{array}{l}5.83 \\
5.95\end{array}$ & 424.3 & $<0,01$ \\
\hline
\end{tabular}

In Nederland werden de uitstrijkjes in het kader van het bevolkingsonderzoek tot 1983 afgenomen door speciaal daarvoor opgeleide vitstrijksters. Op enkele plaatsen (Leiden, Utrecht) gebeurde dit tot 1988. Vanaf 1989 maken huisartsen de uitstrijkjes. Recent werden de eerste vergelijkingen gepubliceerd (Boon e.a. 1991 tussen de uitstrijkjes uit 1988 (uitstrijksters) en 1989 (huisartsen). Het aantal gemaakte uitstrijkjes blift ongeveer constant. Het percentage cytologisch positieve $(\geq$ sterke dysplasie) uitstijkjes stijgt met een factor 3.5 (Leiden) en 5.1 (Utrecht). Ook het percentage histologische positieve scores stijgt in Leiden met een factor 4. Alles wilst erop dat een groep high-risk vrouwen, die door het vroegere bevolkingsonderzoek niet berelkt werd, nu door de eigen huisarts wel bereikt wordt. Dit geldt met iname voor gescheiden vrouwen en voor weduwen.

\subsection{Ervaring}

Het is moeilijk om de uitstrijkervaring van individueel werkende artsen te bepalen. Dit is wel mogelijk voor uitstrijk-istlers, die in dienstverband en binnen een vaste setting werken, zoals onder meer het geval is bij de screensters van het Nederlands bevolkingsonderzoek. Hierover zijn dan ook publicaties beschikbaar.

Vooijs vond in $1986 \mathrm{nog}$ geen significant verschil in percentage uitstrijkjes met endocervicale en/of metaplastische cellen tussen een groep van de 5 meest ervaren screensters (9.000-30.000 uitstrijkjes per persoon) en de rest van zijn groep (1.200-2.000 uitstrijkjes per persoon) (Vooijs e.a. 1986/. In een later overzicht (Vooijs 1988 ) over 107.147 uitstrijkjes vond hil bij eenzelfde vergeliking wel een verschil $(96.6 \%$ versus $94.7 \%)$. Hij signaleert echter ook belangrijke verschillen tussen individuele screensters en tussen de opeenvolgende jaren (Vooijs 1988 ).

Als deze vergelijking doorgetrokken wordt naar de oogst aan pathologische cellen. blijken meer ervarem screensters duidelijk meer pathologie te vinden dan minder ervaren collega's. Het relatief risico is 6.5 voor matige dysplasie of meer en 5.82 voor ernstige drsplasie of meer (Vooijs e.a. 1986).

\subsection{Individuele factoren}

Verschillende auteurs (Centrum voor kankerpreventie UIA, Boon e.a. 1986, Brink a.a. 1989. Neinstein e.a. 1989) vestigen de aandacht op een belangrijke inter- 
dokter variatie in het percentage uitstrijkjes met en zonder endocervicale cellen, zoals gevonden in overigens homogene groepen uitstrijkende artsen. Opvallend is daarbij dat drie auteurs (Boon ea. 1986, Brink e.a. 1989, Neinsteln e.a. 1989). onafhankelijk van elkaar, vermelden dat na de inschakeling van de cytobrush als afnameinstrument de inter-dokter variatie in belangrijke mate verminderde. Een auteur vermeldt een zelfide bevinding voor de Cervex (Laverty e.a. 1989). Een andere beschmift juist een toename van deze inter dokter variatie bij overschakeling van Cytobrush naar Cervex (Boon 1989).

Ook problemen in het priveleven van de uitstrijk(st)er worden gesignaleerd als potentiële oorzaken voor het tijdelijk slechter functioneren als uitstrijk(st)er (Vooijs. e.a. 1986).

\section{Opleiding en feed-back}

Op verschillende wijzen is geprobeerd artsen ertoe te brengen om uitstrijkjes van betere kwaliteit af te leveren. Het is aannemelijk dat het opstellen en veirspreiden van goede protocollen of standaarden in dit proces een belangrijke stap kan zijn. Het is dan wel van essentieel belang dat dergelijke protocollen opgesteld en uitgetest worden binnen de groep van artsen die er achteraf gebruik van moeten maken (Anoniem 1989). Op het congres van de Europese wetenschappelijke huisartsenvereniging (SIMG) in Berlijn 1990 bleek eens te meer hoe pogingen om door buitenstaanders opgestelde standaarden in de huisartsengroep ingang te laten vinden steeds tot mislukking leiden.

Waar delaatste jaren voortdurend geëxperimenteerd wordt met nieuwe en hopelijk betere afnametechnieken, is het belangrijk dat de praktische resultaten hiervan op een voldoende indringende wijze aan de betrokken artsen en paramedici doorgegeven worden (Baker 1989). Ook eigen ervaring leert ons dat het rondsturen van schriftelijke informatie daarvoor onvoldoende is. Uit Amerikaanse en Engelse publicaties (Fleming e.a. 1983, Kane e.a. 1971) blijkt dat het volgen van een speciale "postgraduate" cursus geen invloed had op het aantal uitstrijkjes dat de betrokken artsen afnemen. $\mathrm{Er}$ is geen reden om an te nemen dat de resultatem daarvan beter zouden zijn op de kwaliteit van de afnames. Consultatie door ervaren uitstrijk(st)ers is voorgesteld (Steiner 1989), maar lijkt in de praktijk moeilijk uitvoerbaar. Vooijs beschrijft wel een positief effect van 'on the job training" bij uitstrijksters van het bevolkingsonderzoek, die slechter dan gemiddeld presteren (Vooijs 1988).

Als wij een verbetering van de afnamekwaliteit wensen, betekent dit dat er gewerkt moet worden aan een gedragsverandering bij de betrokken uitstrijk-(st)ers. Voor gedragsverandering is informatie wel nodig, maar niet voldoende. Op het gebied van de cervixcytologie wordt er veel verwachit van feed-back naar de uitstrijk(st)ers over de afnamekwaliteit van de door hen ingestuurde uitstrijkjes (Baker 1989, Stock e.a. 1988). Daarbij wordt geadviseerd dit aan te vullen met geregelde overzichten, die de individuele arts in staat stellen zijn eigen resultaten te vergelijken met die van collega's (Baker 1989). Van belang hierbij is de waarschuwing (Steiner 1989) dat het in een (Amerikaans) vrije markt systeem voor cytologen well 
eens moeilik zou kunnen worden am te veel slechte beoordelingen te geven aan de artsen, die de uitstrijkjes leveren waarvan zij uiteindelijk zelf voor hum bestaan athankelijk zijn.

In verschillende centra is het inmiddels gebrukelijk om bij ieder uitstrijkje de afnamekwaliteit te evalueren of om tenminste het al dan niet aanwezig zijn van endocervicale cellen te vermelden. Boon e. a, beschrijven in dit verband een stijging van het percentage endocervicalen positieve uitstrijkjes van $70 \%$ naar $84 \%$ binnen én jaar nadat het laboratorium de resultaten van iedere arts negistreerde en opvallend slecht presterende artsen telefonisch instrueerde Ook de eerder vermelde positieve effecten bij uitstrijksters uit het Nederlands bevolkingsonderzoek zullen wellicht mede beirnvloed zijn door de geregelde feed-back.

\section{BESLUIT}

Er is in verschillende studies en voor verschillende pathologiecriteria aangetoond dat de kans op het vinden van pathologie groter is wanneer een uitstrijkje endocervicale cellen bevat (Grootenhuis 1989, Killough e.a. 1988, Lindhorst e.a. 1978, Vooijs 1988]. Daarenboven stigt het relatieve aantal pathologische uitstrijkjes in een tweede witstrijkje bij patiënten bij wie geen endocervicale cellen gevonden waren in een vorig uitstrijkje (Vooljs 1988 ) en is er een positief verband tussen de kans op een vals negatief uitstrijkje en de afwezigheid van endocervicale of metaplastische cellen (Woodman e.a. 1989). Pathologie wordt echter, zij het in mindere mate, in alle studies ook gevonden in uitstrijkjes zonder endocervicale cellen en vals negatieve uitstrijkjes kumnen voorkomen ondanks de aanwezigheid van endocervicale cellen (Boon e.a. 1986. Boon e.a. 1986c , Detweiler e.a. 1989, Vooijs e.a. 1986, Woodman e.a. 1989).

Er is nog te weinig gepubliceerd over het verband tussen andere kwaliteitskenmerken en het vinden van pathologie om hierover tot een duidelijke uitspraak te kunnen komen.

Een aantal aspecten van het cytologisch beeld van een cervixuitstrijkje vormen een argument voor de conclusie dat de overgangszone bij het uitstrijken tenminste geraakt is:

- hot vinden van metaplastische cellen

- het vinden van zowel endocervicale cellen als plaveiselcellen.

Zelfs als aan deze criteria voldaan is, kan niet geconcludeerd worden dat de volledige overgangszone uitgestreken is. Er blijft dus ook een (geringe) kans dat een afwijking gemist wordt.

Als aan geen van de beide hierboven genoemde vereisten woldaan is, moet echter geconcludeerd worden dat de overgangszone len dus de lokalisatie van een potentiële afwijking) wellicht gemist is.

Het vinden van pathologische cellen (CIN) is op zichzelf onvoldoende aanwijzing dat de overgangszone bereikt is. Er kunnen elders losgeraakte cellen opgepikt zijn. Uiteraard wordt dit op dat ogenblik een academische discussie. 
Men dient voorzichtig te zijn met de interpretatie van cytologisch onderzoek van patiënten na radiotherapie of hysterectomie. Kleine hoeveelheden bloedverlies hebben wellicht geen belangrijke invloed op de kwaiteit van een uitstrikje. Men maakt echter bij voorkeur geen uitstrijkjes tijdens de menstruatie. Tijdens de zwangerschap en de post-partum periode kan de interpretatie van een uitstrikje problemen opleveren. Bij vrouwen met een afwijking ter hoogte van de portio met contactbloedingen en met postmenopauzaal bloedverlies is er een verhoogde kans. op een afwijkend uitstrijkje. Andere klachten en symptomen zijn geen goede voorspellers van CIN. In de periode vóór het maken van een uitstrijkje, moet men vagina en cervix zo weinig mogelijk beïnvloeden. Een tweede uitstrijkje ter controle van een vorig, moet bij voorkeur niet vroeger dan zes weken, mogelijk zelfs drie maanden na de eerste afname worden verricht.

Op basis van deze literatuurstudie lijkt de combinatie van Spatel en Cytobrush op dit ogenblik de meest aangewezen techniek voor het maken van cervixuitstrijkjes. De Cervex plaatst zich als een veelbelovende, zij het nog beperkt geevalueverde en dure tweede.

Fixatie dient onmiddellijk te gebeuren na het uitstrijken op het objectglaasje. Dit betekent dat de uitstrijk(st)er het nodige materiaal dicht bij de hand moet hebben. Haarspray kan in principe gebruikt worden. Het is dan wel noodzakelijk dat het laboratorium hiervan op de hoogte is en de gepaste maatregelen neemt om artefacten te voorkomen. Het gebruik van een speciaal bereide commerciële spray lijkt alleszins veiliger.

De kwaliteit van de uiltstrijkjes lijkt te stijgen met de ervaring van de uitstrijk(st)er, Er is niet duidelijk aangetoond dat daarnaast een verband zou bestaan met de discipline. Er bestaat op alle niveau's een sterke inter-uitstrijk(st)er variatie, die de invloed van ervaring of beroepsgroep lijkt te overstijgen. 


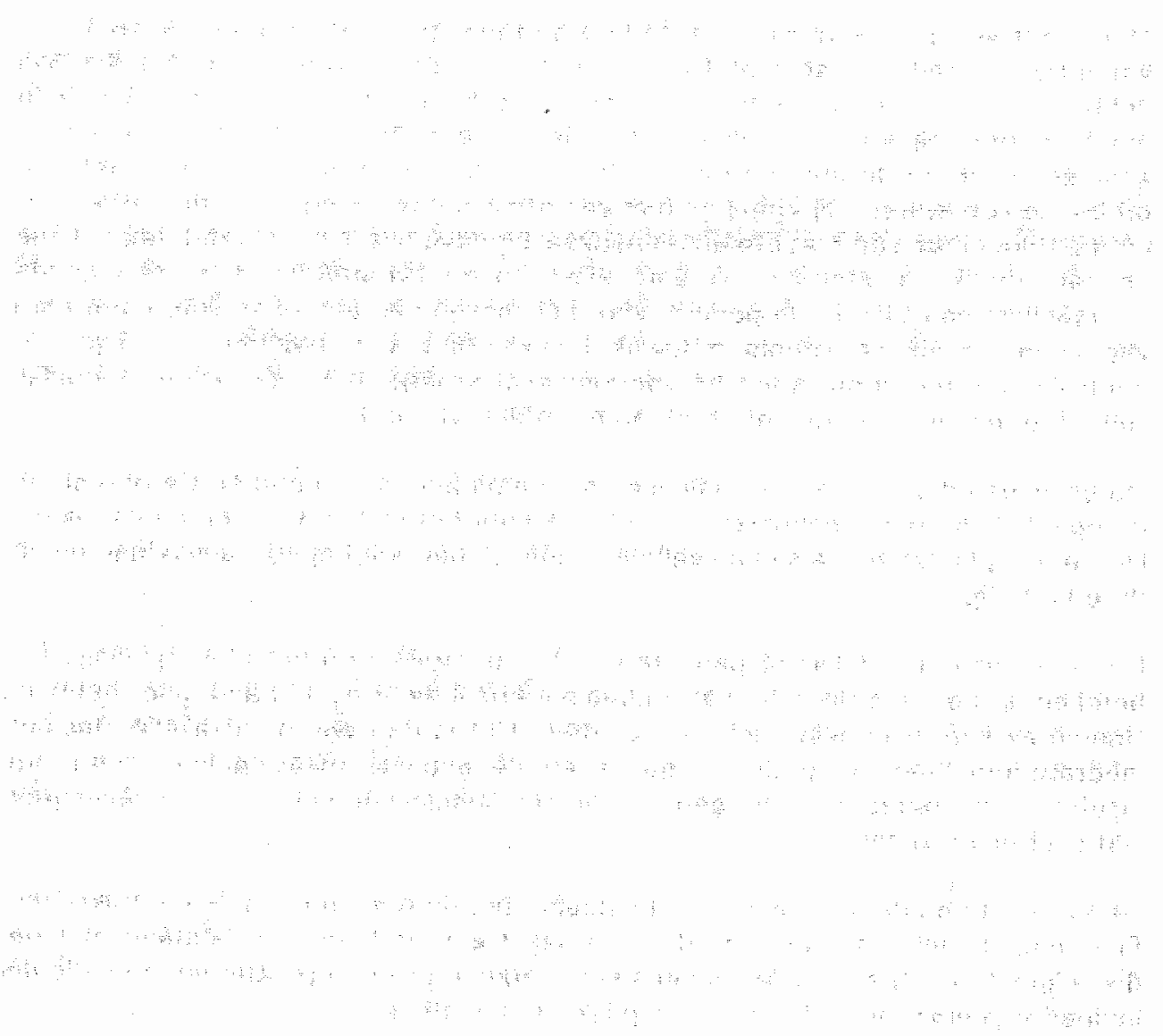


HOOFDSTUK 2

\section{INVLOED VAN GEOGRAFISCHE FACTOREN OP DE AFNAMEKWALITEIT VAN CERVIXUITSTRIJKJES}

Uit de literatuurverzameling die in hoofdstuk 1 beschreven is, werden 33 publicaties geselecteerd die expliciete informatio bevatten over de gebruikte afnametechniek, over de oogst aan endocervicale cellen en over het land waar het onderzoek plaats wond.

Analyse van deze publicaties suggereert een belangrijk verschil in de afnamekwaliteit van cervixuitstrijkjes tussen verschillende landen en streken, ook na controle voor de gebruikte afnametechmiek en voor een eventuele overwegende inwloed van éen of enkele grootschalige studies.

De inhoud van dit hoofdstuk is een bewerking van:

* Buntinx F., Crebolder H.F.J.M., Essed G.G.M., Knottnerus J.A. Geographical variations in the sampling quality of cervical smears. Eur J Obstet Gynecol Reprod Biol. Aanvaard voor publicatie. 


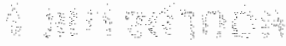

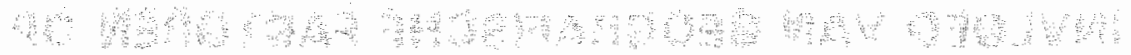

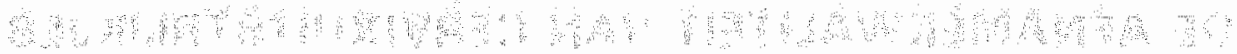

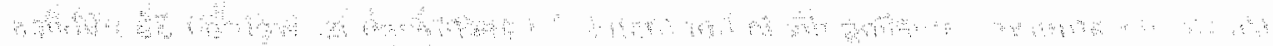

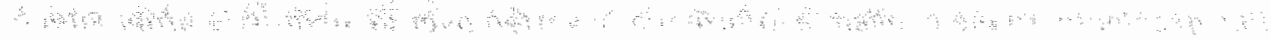

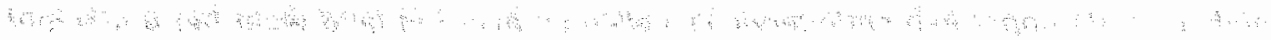

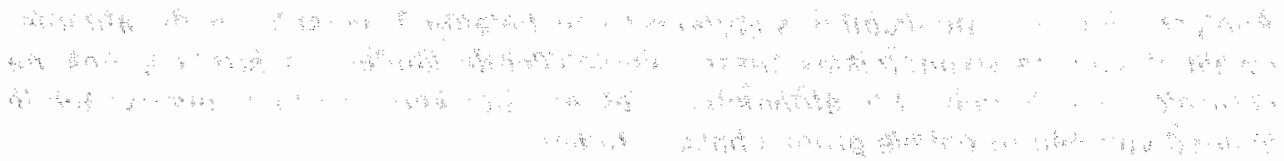




\section{INLEIDING}

Recent verscheen in de British Medical Journal een altikel waarn wordt gewezen op een hoog aantal intervalkankers van de cervix (Mitchell e. a. 19901. Ook andere auteurs hebben hier in het verleden de aandacht op gevestigd en stellen op basis daarvan vragen bij de efficiëntie van cervixscreening als middel ter preventie van cervixcarcinoom (Mc Cormick 1989).

Bij het beoordelen van dit argument is het nodig dat men kan bouwen op resultaten afkomstig van uitstrijkjes van goede kwaliteit. Uit de meeste beschikbare rapporten komen echter ernstige problemen met de kwaliteit van de afname en de verwerking van cervixuitstrijkjes naar voren. Verschillende factoren kunnem hiervan een oorzaak zijn: het moment van de afname, de leeftijd van de patiënte, recente manipulaties ter hoogte van de vagina, het gebruikte afname-instrument, de fixatietechniek, de ervaring en het beroep van de uitstrijk(st)ers. Ook andere, regionaal of nationaal bepaalde verschillen kunnen daarbijeen rol spelen.

In het kader van een literatuurstudie naar de afnamekwaliteit van cervixuitstrijkjes, hebben we nagegaan of er verschillen bestaan tussen landen of streken met betrekking tot de afnamekwaliteit van de uitstrijkjes, hier uitgedrukt als het al dan niet voorkomen van endocervicale en/of metaplastische cellen.

\section{METHODE}

Onze gegevens komen uit het literatuuronderzoek dat uitgebreid beschreven is in hoofdstuk 1 wan dit proefschrift.

Voor deze analyse werden alle artikelen geselecteend die expliciete informatie bevatten over het land waar de gegevens verzameld werden, over de oogst aan endocervicalle cellen en over de gebruikte afnametechniek. In 33 artikelen vonden wij alle noodzakellijke gegevens (Boon e.a. 1986, Boon e.a. 1989, Bourne e.a. 1976, Cecchini e.a. 1989, Chang 1989, Colon e.a. 1983, Deckert e.a. 1988, Dotters e.a. 1988, Engels e.a. 1990, Erp van e.a. 1988, Gay e.a. 1985, Glenthoj e.a. 1986, Goorney e.a. 1989, Gupta e.a. 1987. Hamblin e.a. 1985, Kawaguchi e.a. 1987, Kivlahan e.a. 1985, Kristensen e:a. 1989, Laverty e.a. 1989, Neinstein e.a. 1989, Pistofides 1984, Pistofides 1988, Reismann 1988, Selvaggi e.a. 1989. Spurrett e.a. 1989, Stock e.a. 1988, Taylor e.a. 1987, Trimbos e.a. 1986, Vierhout 1987, Vooijs 1989, Vooijs 1988, Vooijs e.a. 1985, Wachtel e.a. 1974l. Hieronder waren 31 vergelijkende studies waarbij de invloed van verschillende afnametechnieken op de afnamekwaliteit werd nagegaan.

Op basis hiervan berekenden wij voor een aantal landen en gebieden het percentage uitstrijkjes met endocervicale en/of metaplastische cellen. Daarvoor hebben we de som van alle uitstrijkjes met endocervicale en/of metaplastische cellen uit iedere studie, afkomstig uit een bepaald gebied, gedeeld door de som van alle uitstrijkjes uit dat gebied die beschreven werden. Bij deze percentages werd ook een $95 \%$ betrouwbaarheids interval vermeld (Diem e.a. 1978 ).

De resultaten werden gecontroleerd voor het gebruikte afname-instrument. Daarbij werd gerapporteerd over alle methoden die in tenminste drie verschillende gebieden gebruikt zijn. 
Voor alle afnametechnieken samen hebben wij onze berekeningen herhaald, gebruik makend van de gemiddelden van de resultaten van iedere affonderlijke studie. Op deze wijze controleren wij voor een eventuele overwegende invioed van een of meerdere grote studies.

\section{RESULTATEN}

De resultaten (tabel 2.1) zijn gebaseerd op 33 studies, die samen ongeveer 255.000 witstrijkjes omvatten.

Tabel 2. 1: Regíonale invloeden op het percentage uitstrijkjes met endocervicale en/of metaplastische cellen bij verschillende afnamemethoden thet aantal studies met betrekking tot een bepaalde afnamemethode staat tussen haakjes).

\begin{tabular}{|c|c|c|c|c|c|c|}
\hline मी : * : : : : * & US & $\begin{array}{l}\text { Groot } \\
\text { Britt. }\end{array}$ & $\begin{array}{l}\text { Neder } \\
\text { land }\end{array}$ & $\begin{array}{l}\text { Sigandi: } \\
\text { nog viè }\end{array}$ & $\begin{array}{l}\text { Rest } \\
\text { Europa }\end{array}$ & $\begin{array}{l}\text { Phest } \\
\text { wiereild }\end{array}$ \\
\hline spated van Ayre & B8 $(1)$ & $3+(7 *)$ & $84\{1\}$ & $39(11)$ & . & $67(1)$ \\
\hline Cytobrush & 99.11 & - & $98(2)$ & $92(1)$ & . & $82(3)$ \\
\hline Speten+ Cytabrush & $89\lfloor 5\rceil$ & $\because$ & 9913 & $88(1)$ & $89(11)$ & - \\
\hline spatel + Watuenstok & 07191 & & $93(1)$ & 6211 & $49(1)$ & 3911 \\
\hline Extended-tip Spattel & $79(4)$ & $44(3)$ & $90: 6 !$ & , & $44(1)$ & $82(2)$ \\
\hline Carvex & $\because$ & $=$ & $94(3)$ & $\therefore$ & $64(1)$ & 91111 \\
\hline Andere techniekan & $89(3)$ & $8514 *$ & $97(2)$ & $66(1)$ & & $86(2)$ \\
\hline Alle methoder $\quad \therefore \quad: \quad$ & 79011 & 32161 & 9017 & $60(2)$ & $54(2)$ & $82(15)$ \\
\hline $95 \% \mathrm{BH}$ & 78.80 & 38.39 & $90-90$ & 58.63 & 5358 & 81.82 \\
\hline Gemiddelde wan de percentages & 781111 & $56(6)$ & $8917 \%$ & $69(2)$ & $59(2)$ & $79(5)$ \\
\hline
\end{tabular}

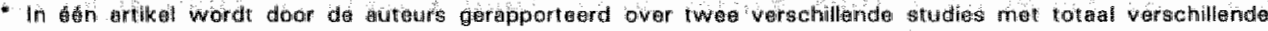
pxienterngrepan.

De afnamekwaliteit lijkt in verschillende landen en gebieden in belangrijke mate te verschillen. Dit blijft zo wanneer onze resultaten gecontroleerd worden voor de afnametechniek en voor de eventuele overwegende invloed van één of enkele grootschalige studies.

\section{DISCUSSIE}

In het totaloverzicht valt op dat Groot Brittannië erg laag scoort en Nederland hoog. De andere gebleden nemen tussemposities in. Deze tendens bliftt stabiel wanneer we de gemiddelden van de resultaten voor iedere afzonderlijke studie ver- 
gelijken. Op deze manier controleren we voor een mogelijk overwegende invloed van één of enkele studies gebaseerd op een groot aantal uitstrijkjes. De verschillen tussen de gebieden zijn ook redelijk stabiel wanneer we controleren voor de ver schillende afnamemethoden.

Het is duidelijk dat de uitstrijkjes uit deze gepubliceerde studies slechts een klein deel vormen van alle cervixuitstrijkjes die in een bepaald land afgenomen worden. Het is moeilijk te beoordelen of de resultaten van niet gepubliceerde uitstrijkjes in belangrijke mate zouden verschillen van de gepubliceerde resultaten. Toch is het aantal gerapporteerde uitstrijkjes (28.851 voor het Verenigd Koninkrijk en 152.561 voor Nederland) en observaties per afnametechniek en per land (respectievelijk 14 en 18) vrij groot. Van een groot aantal landen en gebieden werden helemaal geen gepubliceerde onderzoeksresultaten gevonden: er waren geen gegevens van Zuiden Oost-Europa, van grote gebieden van Azië en van vrijwel volledig Afrika en Zuid-Amerika. Er is geen reden om aan te nemen dat de situatie in deze gebieden beter is dan in de gebieden waarover gepubliceerde gegevens beschikbaar zijn. Wanneer de verschillen tussen de landen en gebieden zo groot zijn als door deze analyse gesuggereerd wordt, lijkt het ons noodzakelijk dat de resultaten in de meer problematische gebieden verbeterd worden, vóór er een definitief oordeel kan uitgesproken worden over voor- en nadelen van screening ter preventie van cervixcarcinoom.

Het gebruik van moderne afnamemethoden kan daarbij een belangrijke verbetering opleveren. Uit deze anallyse komt echter de suggestie naar voren dat ook andere factoren, geassocieerd met de werksituatie in een bepaald gebied, bekeken moeten worden. De workload en de motivatie van de uitstrijkende artsen, hun opleiding en mogelijkheden tot feed-back lijken ons daarbij belangrijke aanknopingspunten. 


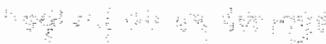

$\because+\infty \quad \cdots$

.

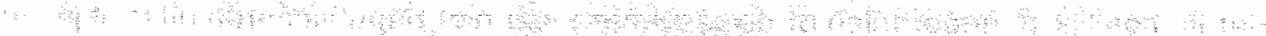

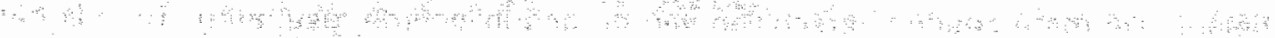

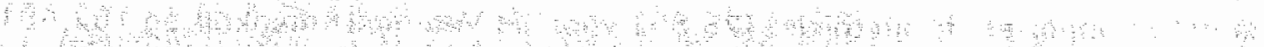

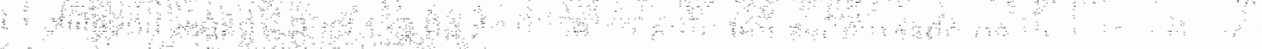
a

$\because$ :

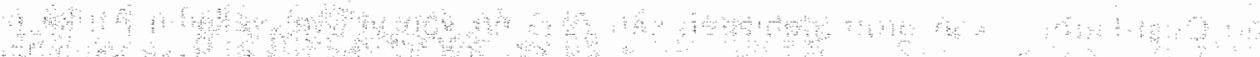

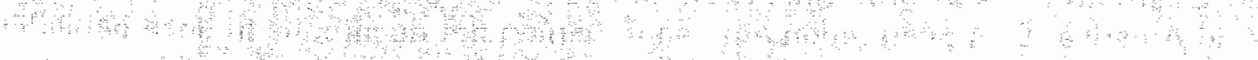

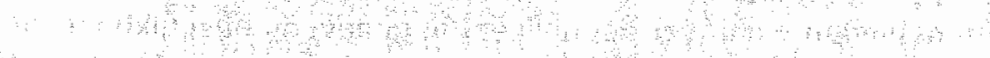

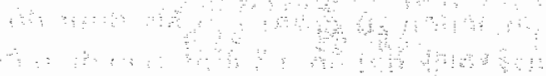

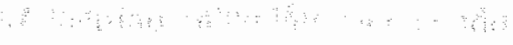

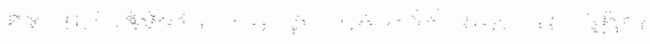

$\therefore$ a

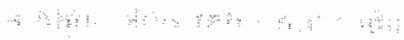

$\because 4, \cdots+\cdots$

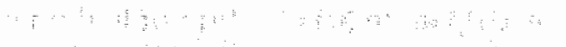

$\therefore$ : 


\section{HOOFDSTUK 3}

\section{LITERATUUROVERZICHTEN EN META-ANALYSE}

Methodologische kanttekeningen

Bij het uitvoeren van de literatuurstudie waarop de twee vorige hoofdstukken gebaseerd zijn, werd gebruik gemaakt van een aantal nieuwe technieken, die onder de naam meta-analyse geleidelijk ingang vinden in de medische literatuur.

In dit hoofdstuk wordt onderzocht welke nieuwe kansen deze werkwijze biedt en met welke risico's en valkuilen rekening moet gehouden worden. Tevens wordt de gevolgde werkwijze uitvoerig beschreven.

De inhoud van dit hoofdstuk is een bewerking van:

* Buntinx F., Crebolder H.F.J.M., Essed G.G.M., Knottnerus J.A. Literatuuroverzichten en meta-analyse. Deel 1: Een kwalitatieve benadering. Huisarts Nu. 1991; 20:160-165.

* Buntinx F., Crebolder H.F.J.M. Essed G.G.M., Knottnerus J.A. Literatuuroverzichten en meta-analyse. Deel 2: Bundeling van de resultaten van verschillende studies. Huisarts Nu 1991; 20: 208-211. 
Twee doot andere auteurs samengestelde tabellen on een figuur werden als woorbeeld bil dit hoofdstuk opgenomen. Zij werden met welwillende toestermming van witgever en autewr overgenomen uit Huisarts en Wetenschap (tab 3.1 en 3.2) en wit The British Medical Joumal (fig 3. 1). 


\section{Deel 1 \\ EEN KWALITATIEVE BENADERING}

De vakliteratuur vormt, samen met het informeel intercolleglaal overleg, binnen de medische wereld de belangrijkste methode om ervaringen, opvattingen en onderzoeksresultaten uit te wisselen (Vander Stichele e.a. 1985).

Het is niet gebruikelijk dat een onderzoeker erin slaagt om via een perfect onderzoek een onderzoeksvraag volledig en definitief te beantwoorden (Russell Teagar den 1989). Vaak ontstaat dan ook de behoefte om de bestaande kennis rond een onderwerp of vraagstelling te inventariseren en op een kritische wijze te evalueren. Wetenschappelijke interesse kan daarvoor de aanleiding zijn, maar ook de behoefte aan wetenschappelijke informatie bij het nemen van klinische of maatschappelijke beslissingen (Bouter e. $a_{2}$ 1990). Wanneer de resultaten van een dergelijke studie op hun beurt aanleiding zijn tot een publicatie, spreekt men van een overzichtsarti$\mathrm{kel}$, in het Engels een "review article" (Light e.a. 1984).

Soms is er over een onderwerp zo weinig bekend, dat er niet één relevante publicatie gevonden wordt. Een eindoordeel kan echter evenzeer moelijk ziln als blikt dat over eenzelfde vraagstelling niet éen, maar tientallen artikelen gepubliceerd zijn, gebaseerd op onderzoek van wissellende kwaliteit, waarbij verschillende methoden gebruikt zijn en die uiteenlopende, vaak zelfs tegenstrijdige resultaten tonen. Zo publiceerden Gianross e.a. een review over 147 studies, waarbij het resultaat van inspannings-ECG's vergeleken werd met coronarografie (Gianrossie.a. 1989). De gevonden sensitiviteiten varieerden van $23-100 \%$ en de specificiteiten van $17-100 \%$. Er is veel evolut te in de techniek die gebruikt wordt bij het opstellen van literatuur overzichten. Het literatuuronderzoek ontwikkelt zich tot een eigen wetenschappelijke methode, met strikte regels en afspraken. De relatieve vrijblijvendheid verdwilnt. Uiteindelijk wordt elk literatuuroverzicht op deze wijze een afzonderlijk, nieuw onderzoek, dat dient te beantwoorden aan dezelfde algemene vereisten van objectiviteit, controleerbaarheid en precisie die gelden voor ieder wetenschappelijk onderzoek (Light e.a. 1984, Ter Riet e.a. 1989d).

De laatste jaren wordt in dit verband de term meta-analyse gebruikt: het gaat dan om een gestructureerde, systematische kwalitatieve en kwantitatieve evaluatie en integratie van de resultaten van meerdere onafhankelijke studies (Jenniceck 1989 ). De term werd in 1976 reeds gebrulkt door Glass (Glass 1976), maar won gedurende de laatste jaren enorm aan populariteit in de epidemiologische en farmacologi sche literatuur. Sinds 1989 wordt hif ook als MESH-term gebruikt bij het indexeren ten behoeve van Index Medicus (Dickersin e.a. 1990).

\section{Kenmerken van een overzichtsartikel}

Een overzichtsartikel wordt opgebouwd uit dezelfde componenten als elk ander researchartikel. In een inleiding beschrijt de auteur warom hij zijn onderzoek verricht en wordt (vooral) de preciese onderzoeksvraag geformuleerd. Bij de beschrijving van de gebruikte methode wordt eerst expliciet beschreven op welke wijze de gebruikte teksten geselecteerd zijn. Daarna wordt aangegeven of en zo ja welke, criteria gebruikt zijn om de kwaliteit wan deze artikelen te evalueren. Wanneer men resultaten uit verschillende publicaties wenst te bundelen of te vergelliken, worden de daarvoor gebruikte methoden, met inbegrip van de statistische 
technieken vermeld en, waar nodig, beschreven. De resultaten worden uiteraard zo overzichtelik mogelijk gepresenteerd en het geheel wordt afgesloten met een bespreking van de gevonden resultaten en hun consequenties, eventueel in de vorm aan van een richtlijn voor klinisch of maatschappelijk handelen of van een voorstel voor aanvullend gericht onderzoek.

\section{Selectie van de gebruikte publicaties.}

Het is ondenkbaar dat in een rapport over een klinische studie de beschrijving van de patiëntenselectie weggelaten zou worden. Even essentieel is de beschrijving en de verantwoording van de literatuurselectie voor een overzichtsartikel. Wie uit zijn bestand een aantal artikelen verzamelt en probeert daar besluiten op te baseren. wordt geconfronteerd met dezelfo kans op selectiebias als de klinisch onderzoe-

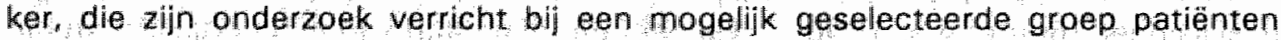
zonder de optredende selectie tenminste te beschrijven (Bouter e a 1990),

Het is dus belangrijk om de te verwerken artikelen op een verantwoorde wijze te kiezen. Een voor de hand liggende werkwijze is witeraard het verzamelen van alle rapporten, die ooit gepubliceerd zijn en die de te onderzoeken vraag behandelen. In een wereld met meer dan 20,000 medische tijdschriften en een onoverzichtelijke berg grijze literatuur, is dit een hele klus Daarom bouwt men hier beperkingen in die echter wel moeten kunnen worden verantwoord.

Zo baseerden wij ons voor de literatuurstudie over de invloed van verschillende afnametechnieken op de afnamekwaliteit van cervixuitstrijkjes (hoofdstuk 11 op een computersearch van Medline lde computerversie van de Index Medicus sinds die in 1964 geautomatiseerd werd), aangevuld met FAMLI, een internationaal huis. artsgeneeskundig indexsysteem. Hieraan werden artikelen toegevoegd, die wij verkregen uit rechtstreekse contacten met andereonderzoekers in dit veld. Tenslotte zorgden de literatuurlijsten bij ieder artikel nog voor een nieuwe oogst aan publicaties via een systeem dat ooit "sneeuwballen" genoemd werd (verhellen e.a. 19861.

Het gebruik van geautomatiseerde indexen als basis voor het verzamelen van publicaties is een vaak gebruikte techniek, welke tenminste borg staat voor een bepaalde graad van volledigheid en objectiviteit. Toch kleven hieraan duidelijke beperkingen. Alle indexsystemen beperken zich tot een selectie van tijdschriften. In principe geschiedt deze selectie op basis van kwaliteitscriteria, maar er spelen ook andere factoren mee. Het belangrijkste medisch indexsysteem, Index Medicus, refereert nog steeds nauwelijks huisartsgeneeskundige tijdschriften, zodat aanvulling via een specifiek op de huisartsgeneeskunde gerichte index als FAMLI noodzakelijk is. Daarenboven genieten engelstalige tijdschriften een zekere voorkeur.

Er kan ook vertekening optreden door het feit dat redacties van tijdschriften vaak meer interesse blijken te hebben voor studies waaruit een duidelik liefst positief effect blijkt, zodat (vooral kleinere) negatieve studies of studies die geen duidelijk antwoord bieden op de onderzoeksvraag minder gemakkelijk gepubliceerd worden. Klassiek is in dit verband de studie van Mahonney uit 1977, waarbij 77 referees in vijf groepen een fictief artikel beoordeelden met een identieke methodenparagraaf, maar wisselende resultaten en/of discussietendens. De beoordeling door de verschillende groepen referees was veell positiever bij een positief dan bij een negatief onderzoeksresultaat (Mahonney 1977 ). 
Uiteraard gebeurt het ook dat een onderzoeker in de loop van de studie ziln interesse verliest of de moed opgeeft, zodat alle resultaten ongepubliceerd in een lade blijven liggen.

Dit alles geeft bij het bundelen van de resultaten een vertekening, meestal in het voordeel van een positief effect (Meilman 1990, Dickersin 1990). Men gebruikt in dit verband vaak de term publicatiebias. Enkele auteurs die hierover onderzoek deden, suggereren dat gepubliceerde studies gemiddeld kwalitatief beter zinn omdat zij de screening door referenten van het betrokken tijdschrift passeerden (Henderson 1989 ) en dat in realiteit slechts weinig goede studies van deze selectie het slachtoffer worden (Hofmans 1990). Uit een enquête onder 141 auteurs van gepubliceerde gerandomiseerde studies bleek echter dat $41 \%$ van hen volledig afgewerkte, maar nooit gepubliceerde studies in de kast haddenliggen. Volgens de ervaringen van deze mensen zou het publicatiepercentage $77 \%$ bedragen voor studies met een positief resultaat (de onderzoekshypothese wordt bevestigd of een vermoed verband blijkt inderdaad te bestaan) en $42 \%$ voor studies met een negatief iresultaat (Russell Teagarden 1989), Kay Dickersin publiceerde in de JAMA een overzicht van vier min of meer vergelijkbare studies (Dickersin 1990). In drie van deze vier studies werd er ook een relatie gevonden tussen de kans op publicatie van een onderzoeksresultaat en het aanwezig zijn van een (significant) positief resultaat in het voordeel van de onderzoekshypothese.

Auteurs berekenen ter beoordeling van mogelijke publicatiebias soms het aantal bijkamende (fictievel studies met een negatief resultaat dat nodig zou zijn om het eindresultaat van de meta-analyse na pooling van alle afzonderlijke resultaten onbeslist te maken Henderson e.a. 1989, Ward e.a. 1989\%. Men noemt dit met een vakterm de resistance van de meta-analyse. Ook op het niveau van de tijdschriftredacties zijn maatregelen voorgesteld om publicatiebias te voorkomen (Sharp 1990, Chalmers e.a. 1990). Zij stuiten echter meestal op practische bezwaren, waarbij vooral de leesbaarheid van het tijdschrift en financiële konsekwenties een rol spelen (Sharp 1990).

Uiteindelijk lijkt er voor publicatiebias slechts én oplossing te bestaan: publicatiebias kan wellicht grotendeels voorkomen worden als alle researchprojecten centraal geinventariseerd worden op het ogenblik dat zij gestart worden (Bouter e.a. 1990, Dickersin 1990). Het zou dan mogelijk worden rekening te houden met de resultaten van alle gestarte studies (dit is te vergelijken met hêt intention to treat principe in de gewone statistische analysel.

Er bestaan reeds pogingen op dit gebied. Zo worden oncologische studies in een register opgenomen zodra zij in aanmerking komen voor financiering (Yach 1990 ) en bestaan en afzonderlijke databanken voor perinataal onderzoek (Chalmers e.a. 1991), voor epidemiologisch kankeronderzoek (Colman e.a. 1989) en voor AlDS onderzoek (Dickersin 1990). Toch moet er ook bij dergelijke inventarisaties rekening gehouden worden met andere mogelijke bronnen van vertekening. Zo zou een miet gesubsidieerde studie bijwoorbeeld wel eens moeilijk tot een dergelijke datebank kunnen doordringen.

Sommige onderzoeken duren vele jaren. Naarmate het aantal onderzochte of behandelde patiënten toeneemt, stijgt ook de overtuigingskracht van het onderzoek. In dergelijke gevallen worden er regelmatig tussentijdse rapporten gepubliceerd op basis van gegevens die enkele jaren later opnieuw opduiken in een rapport over een langere tijdspanne. De reviewer dient hierop bedacht te zijn en er 
zorguuldig over te waken dat er geen dubbeltelling optreedt van de resultaten bij eenzelfde patiënt.

\section{Methodische Waardering}

Van elke studie afzonderlijk moet de methodische $k$ waliteit nagegaan worden. Wanneer dit niet gebeurt, loopt men kans conclusies te baseren op ondeugdelijke onderzoeken, lets wat men kan vergelijken met informatiebias (en misclassificatlebias/ in een gewoon onderzoek.

Ook voor het evalueren van de methodische validiteit van de afzonderlijke studies zijn regels beschreven (Ter Riet e.a. 1990):

1. De gebruikte criteria moeten op voorhand vastgelegd en uitdrukkelijk beschreven zijn. Uiteraard moeten voor alle onderzochte studies dezelfde criteria gebiruikt worden.

2. Er moeten preciese inclusie- en exclusiecriteria geformuleerd worden met betrekking tot de patiénten (bijvoorbeeld binnen vastgelegde leeftijdsgrenzen) die toegelaten worden, de interventies (bijvoorbeeld alle betablokkers of alleen eer bepaalde groep ervan/ en de effectmaat bijvoorbeeld overlijden of "een verbetering" of "een daling van de bloeddruk met minstens $10 \mathrm{mmHg}$ systolisch"l. Als deze niet voldoendle vergelijkbaar zịn voor de verschillende afzonderlijke studies loopt men het risico appelen met peren te vergelijken.

3. Voor het vastleggen van de criteria is niet alleen kennis van de methodenleer vereist, maar ook inhoudelijke kennis over het onderwerp van het onderzoek. Er zullen andere criteria gelden in een literatuuroverzicht haar het effect van medicatie (bijvoorbeeld gerandomiseerd dubbel-blind onderzoek); naar de invloed van thuiszorg op de overleving van een bejaarde (waar men ook nietgerandomiseerde studies in het overzicht zal betrekkenl, naar de diagnostische waarde van tests (met hun eigen, vaak Bayesiaans geïspireerde methoden en outcome-parameters), naar epidemiologische verbanden tussen een externe factor en een ziekte (waarbij ook case-control studies waardevol kunnen zijn) of naar redenen waarom heroïneverslaafden stoppen met hun gebruik (waar wij grotendeels moeten terugvallen op kwalitatief onderzoek).

4. Daarnaast kunnen, afhankelijk van het onderwerp, extra vereisten als voorwaarde gesteld worden. Daarbij kan het bijwoorbeeld gaan om een minimale follow-up perlode.

Idealiter hoort leder artikel op zijn methodische kwalteit beoordeeld te worden door minstens twee afzonderlijke beoordelaars, die alleen beschikken over de "methode" -sectie van elk rapport en die op dat ogenblik geblindeerd zijn wat betreft de auteurs en vooral de resultaten van het onderzoek (Ter Riet ea. 1989c). Een systeem voor thet omgaan met inter-beoordelaarverschillen moet in de procedure voorzlen zijn. Uiteraard is dit in de praktijk alleen mogelijk wanneer hiervoor voldoende menskracht len dus geld) beschikbaar is.

Sommige auteurs hebben lijsten opgesteld van methodische criteria lLight e.a. 1984, Ter Riet e.a. 1990, Ter Riet 1989c/ waaraan zij telkens purten toekennen. Een voorbeeld hiervan vindt $U$ in tabel 3.1 . 
Tabell 3.1 : Criteria voor het evalueren van de methodische kwalliteit van onderzoeksverslagen met betrekking tot het effect van acupunctuur (Ter Riet e.a. 1989c).

aramtal punten

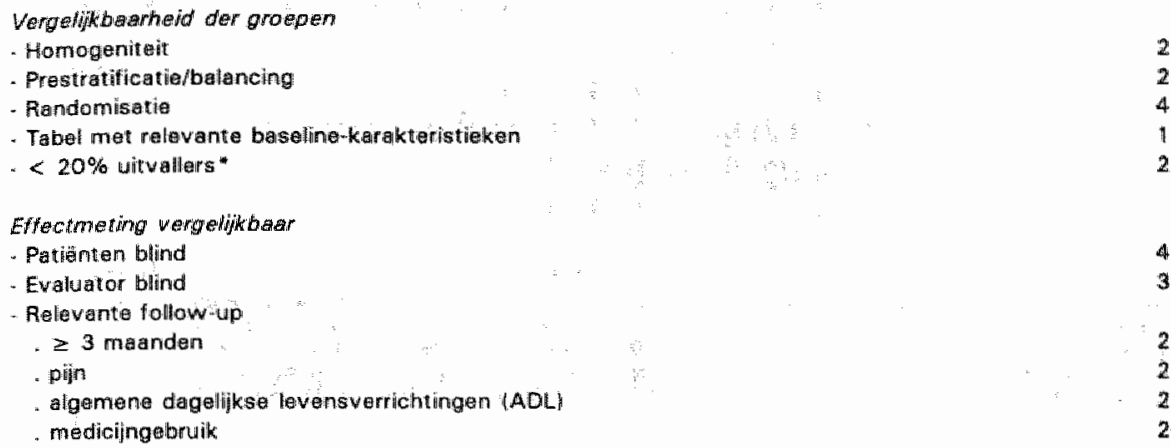

Extra punten

- Pragmatisch exparimant

- $\geq 50$ personan perr groep

DNIIC-omzeiling (non perforatie) *

- Therapie goed besichreven

- Presentatle met ruwa data

- Biwerkingen varmald

Kwaliteit van de acupuncturist vermeld

2

2

2.

Minpunten

- Allen p-wearden in de presentatie van de resultaten

- Voor cross:over experimenten is het criterium $<10 \%$ gehentérd.

- De afkorting DMHIC staait voor Diffuse Noxious Inthibitory Ciontrol.

Deze werkwijze heeft twee voordelen:

Enerzijds krijgt leder onderzoek een totaalscore die een mat is lof geacht wordt te zijn) voor de methodische kwaliteit van de gerapporteerde studie (zie de horizontale lijn in tabel 3.2). De auteurs van het overzichtsartikel kunnen dan besluiten om in hun overzicht alleen studies op te nemen die hoger scoren dan een door hen (arbitrair) gekozen afkappunt. Het is in principe zelfs mogelijk om alle studies op te nemen maar bij de berekening van een (gepoold) eiridoordeel aan elke studie een gewicht toe te kennen in relatie tot zijn methodische kwaliteit.

Anderzijds krijgt men ook voor elk kwaliteitscriterium een totaalscore die de onderzoekers een idee kan geven over hoe het binnen een onderzoeksveld zit met de kwaliteit van het geheel van het onderzoek volgens dit criterium. (zie de vertikale lijn in de tabel 3.21 .

Zo kan bijvoorbeeld blijken dat over een bepaalde vraagstelling veel verschillende studies verricht werden, maar dat de aantallen patiënten telkens erg laag zijn. Dit zou aanleiding kunnen geven tot het opzetten van één groot leventueel multcenter) ondierzoek, dat een duidelijke uitspraak mogelijk kan maken. 
Tabel 3.2: Voorbeeld van een uitgewerkte methodische evaluatie, gebaseerd op de criteria van tabel 3.1 Mier Riet e.a. 1989 ).

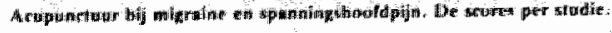

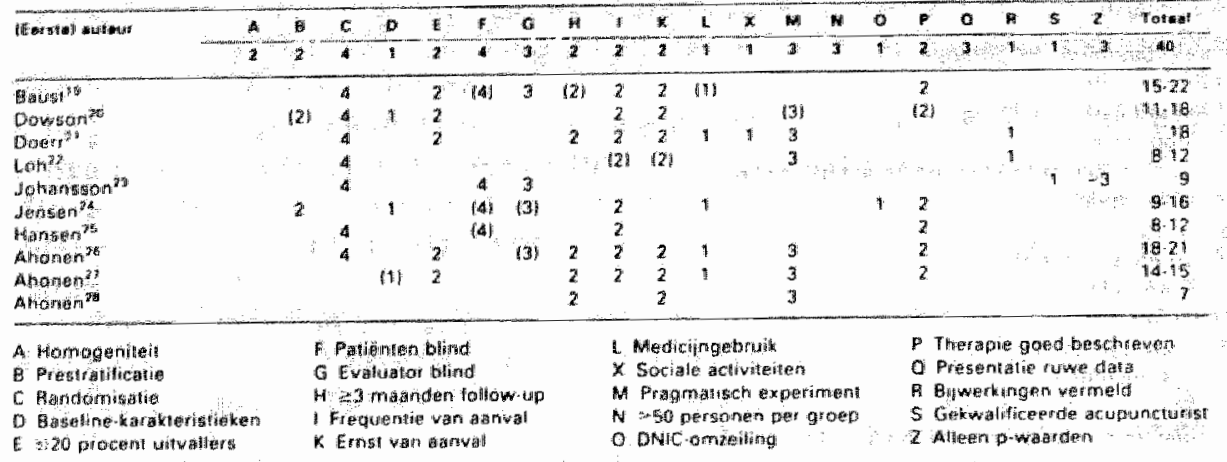

Een nadeel van het puntensysteem is dat voor de keuze van de criteria en de toekenning van een bepaald aantal punten aan elk criterium geen echte regels bestaan en dat iedere reviewer dit dus zelf en op een arbitraire manier moet doen. Niet alle reviewers werken daarom met dezelfde puntenlijsten.

Een veel gebruikt alternatief (Gehlbach 1988, Collins e.a. 1985) bestaat erin dat men de belangrijkste kenmerken van elke studie al dan niet samen met de resultaten, in eem tabel samenvat. Op deze wijze kan de lezer dan zelf zijn conclusies trekken over de wenselijkheid dat een bepaalde studie in het overzicht apgenomen wordt. Vaak wordt hiervan gebruik gemaakt om ook conclusies te kunnen formuleren gebaseerd op een deel van de gepresenteerde studies Hayes e.a. 1990, Collins e.a. 1985), bijvoorbeeld alleen gerandomiseerde studies (zie tabel 1.19 ), studies met patiënten uit een bepaalde leeftijdsgroep of studies over een deelgroep uit een geneesmiddelenklasse (bijvoorbeeld alleen Inderal in plaats van alle betablokkers). Een dergelijke werkwilze geeft ook een inzicht in de grootte en de richting van de vertekening die optreedt door de methodische verschillen tussen de studies (Vach 1990 ).

Het is opvallend dat bil herhaling is vastgesteld dat het effect van een interventiemethode in verschillende studies afneemt naarmate de kwaliteit van de studies toeneemt (Yach 1990, Ter Riet e.a. 1989b). Ook dit kan uiteraard mede te wijten zijn aan publicatiebias, waardoor relatief meer studies van geringe kwaliteit met een positief resultaat gepubliceerd zijn. Voor de betere en grotere gerandomiseerde studies die vaak veel geld en moei te gekost hebben, is dit minder een probleem. Zij worden toch wel gepubliceerd, ongeacht de uitkomst.

\section{Betrouwbarheid van een meta analyse}

Er zijn ondertussen vergelijkingen uitgevoerd tussen het resultaat van een zeer uitgebreide gerandomiseerde multicenterstudie enerzijds en een meta analyse van een aantal kleinere studies met dezelfde vraagstelling anderzijds (Russell Teagarden 1989, Stampfer e.a. 1990). Daarbij werd gebruik gemaakt van de pooling technie- 
ken, die wij in het tweede deell van dit hoofdstuk beschrijven. De resultaten van de grote studies blijken heel behoorlijk overeen te komen met de resultaten de van meta-analyses (Russell Teagarden 1989).

Ook de Food en Drug Administration begint zich bif het nemen van beslissingen op de resultaten van meta-analyses te baseren (Russell Teagarden 1989). Een groter bewijs van kredietwaardigheid is momenteel moeilijk denkbaar.

\section{Deel 2 \\ BUNDELING VAN DE RESULTATEN VAN VERSCHILLENDE STUDIES}

Een literatuuronderzoek is vaak aanleiding tot het mathematisch bundelen (poolen) van de individuele onderzoeksresultaten. Dit heeft belangrijke voordelen maar ook belangrijke risico's. Een belangrijk voordeel is het verkrijgen van éen cijfer, gebaseerd op alle studies die voorhandenzijn. Daarnaast leidt het bundelen van de patientenaantallen van kleinere studies die elk afzonderlijk geen statistisch significant resultaat tonen, soms tot een eindresultaat dat (vanwege de grotere power door het groter aantal patiënten) wel duidelijk statistisch significant is (Bulpitt 1988). Ook het grafisch voorstellen (Collins e.a. 1985 ) van de resultaten van verschillende studies en eventueel van een gebundeld eindresultalat kan erg verhelderend zijn (fig 3.1).

Figuur 3.1: Relatief Risico op pre-eclampsie in negen gerandomiseerde en gecontroleerde interventiestudies, en het gepoold rellatief risico, elk met hun $95 \%$ betrouwbaarheidsinterval en significantieniveau (Collins e.a. $1985)$.

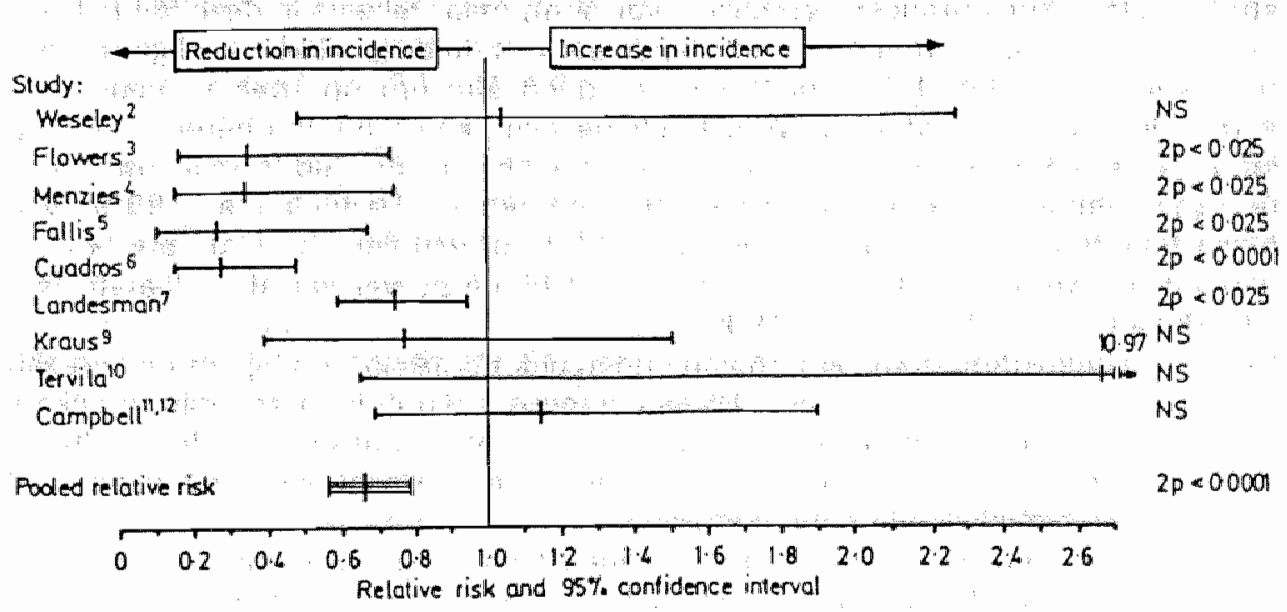

Wanneer gebruik gemaakt wordt van een rellatief risico of een odds ratio als effectmaat, dient men zich bij het uittekenen wel de asymmetrie van een dergelijke 
maat te realiseren: zo komt een $R R$ van 0,2 in de ene richting overeen met een $R R$ van 5 in de andere richting. Sommige auteurs verkiezen daarom een logaritmische schaal (Hedrick e.a. 1989).

Een risico van pooling is dat alle fouten en vertekeningen uit elk der afzonderlije studies in het eindresultaat verborgen en mee verrekend zijn. Het elegante van één cijfer als eindresultaat van een hele reeks studies mag geen aanleiding zijn om de ogen te sluiten woor alle subtiliteiten en compromissen die nu eenmaal eigen zijn aan het design van elk individueel onderzoek.

Een tweede waarschuwing geldt het vergeliken van appelen en peren, waarover wij het reeds hadden bij de bespreking van de inclusiecriteria. Zelden beschikt men voor het maken van een meta-analyse over studies met een identiek design. Toch moet hier voldoende overeenstemming bestaan om enige vergelijking, laat staan pooling van de resultaten, mogelijk te maken. Verschillen zijn niet steeds meteen duidelijk Soms is de onderzoeksmethode van een studie onvolledig beschreven (bijvoarbeeld geen vermelding van de leeftijden van de betrokken patiënten); soms ook zijn de verschillen subtieler. Een yoorbeeld is de vertekening die ontstaat wanneer patiênten in de ene studie geselecteerd worden uit een huisartspraktijk en in de andere studie uit een academisch ziekenhuis. Uiteraard is dit probleem niet specifiek voor een meta-analyse, maar komt het voor in elk literatuuroverzicht. Meta-analyse is erop gericht om juist deze aspecten te onderkennen.

Wanneer verschillende studies uiteenlopende resultaten vermelden als antwoord op dezelfde onderzoeksvraag, zijn er twee mogelijkheden: ofwel er is sprake van een toevalsvariatie en dan zal pooling van de resultaten een belangrijke bijdrage leveren tot het zo nauwkeurig mogelijk schatten van het "ware" antwoord, ofwel toevals" variatie biedt een onvoldoende verklaring voor de verschillen. Dan moet er gezocht worden naar redenen die deze verschillen verklaren. Men spreekt in een dergelijke situatie van interactie of heterogeniteit. Pooling is dan een zinloze bezigheid.

Soms wordt het als een geruststelling ervaren als de effectmaat in de verschillende studies alleen kwantitatieve verschillen vertoont, maar telkens in dezelfde richting wijst. Wanneer daarentegen verschillende studies duidelijk tegenstrijdige resultaten geven (zie tabel 1.15), doet men er goed aan om op zoek te gaan naar verschillen tussen de studies. Voor twijfelgevallen kan men een beroep doen op statistische technieken: men kan gebruik maken van de "odds man out", een grafische techniek die als vuistregel te hanteren is Hedrick e.a. 1989), van logistische regressieanalyse (Hedrick e.a. 1989), of van een chi ${ }^{2}$ test voor heterogeniteit. Er worden echter vraagtekens gezet bij de power van deze laatste test (Henderson e.a. 1989, Lubsen 1990).

Het is een hele stap om resultaten van onderzoek toe te passen bij het nemen van beslissingen in de patientenzorg. De onderzoeksgroep is immers altijd in zekere mate verschillend van de eigen patiëntengroep. Het toepassen van de resultaten van een meta-analyse is nog een grotere stap. De effectmaat is immers gebaseerd op onderling verschillende patiëntengroepen:

Voor de ondersteuning van belelds beslissingen die betrekking hebben op hele populaties (zoals bijvoorbeeld in de politiek gebruikelijk is), hoeft dit geen probleem te zijn. Bij het nemen van een beslissing betreffende een klinisch probleem bij een specifieke patiënt, kan het resultaat van een meta-analyse, zoals overigens ieder onderzoeksresultaat, slechts een van de bouwstenen zijn, samen met de voorkennis van de patient, diens problematiek en vele andere factoren (Russell Teagarden 1989). 
Methode van pooking

Wie de positieve en negatieve resultaten van verschillende studies optelt, daarvan een gemiddelde berekent en dit voorstelt als het eindresultaat van al deze studies. kan in een valkuil terecht komen (Avonts e.a. 1988, Rothman 1986).

Bundeling van de resultaten van verschillende studies kan geschieden met dezelfde technieken die gebruikt worden voor gestratificeerde analyse. Daarbij wordt er een

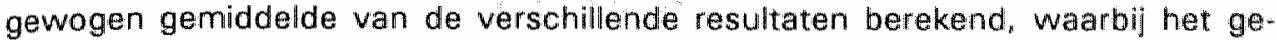
wicht van ledere studie mede afhangt van de variantie van elk deelresultaat (Trock e.a. 1990, Shinton e.a. 19901. Deze kan daarenboven nog gewogen worden voor de grootte van iedere afzonderlijke studie (Wolf 1986.

De meest populaire effectmaat bij deze berekeningen is de Odds Ratio (OR), maar ook het Relatief Risico komt in aanmerking (Gehlbach 1988, Collins e.a. 19857, Stampfer e.a. 1990, Laupacis e.a. 1988, Shinton e.a. 19901, alsmede een relatief verschil (Hayes e.a. 1990, Hedges 1985, Henderson e.a. 1989), een sensitiviteit of specificiteit (Gianrossi e.a. 1989) of een correlatie-coëfficiënt (Hedges 1985. Nagasawa e.a. 1990, Wolf 1986).

Voor de berekeningen wordt vooral gebruik gemaakt van de Mantel-Haenszeltechniek. Er zijn andere mogelijkheden, zoals het gebruik van de maximum likelihood (Hedrick e.a. 1989), maar de Mantel-Haenszeltechniek is zowel conceptueel als qua berekeningen eenvoudiger en is het meest geschikt voor het verwerken van strata met kleinere aantallen en voor de omgang met effectmaten die dicht bij 1 liggen. Er is ook een Bayesiaanse pooling techniek ontwilkkeld (Confidence Profile Methodl. Een voordeel hiervan is dat resultaten van verschillende studie-designs kunnen bijdragen tot één gemeenschappelijk eindresultaat. De methode laat ook toe schattingen van vertekeningen of onzekerheden te verrekenen. Voor iedere afzonderlijke studie wordt een likelihood functie berekend. Daarmee kan men, uitgaande van een priorwaarde voor het effect een posteriorwaarde berekenen (Eddy e.a. 1990). Een laatste alternatief is dat men de resultaten van de verschillende studies, met hun belangrijkste kenmerken als co-variabelen, opneemt in een regressieanalyse (Gianrossi 1989, Hedges 1985, Hodgson e:a. 1989).

Het principe van een Mantel-Haenszel pooling bestaat erin dat niet de outcome parameters van de verschillende afzonderlijke studies gepoold worden, maar wel de oorspronkelijke gegevens van ellke studie (de waarden van de verschillende cellen!.

Een gepoold Relatief Risico, respectievelijk een gepoolde Odds Ratio worden dan berekend via specialal daarvoor ontworpen formules. Voor een pooling van drie interventiestudies krijgen wij dan het volgende:

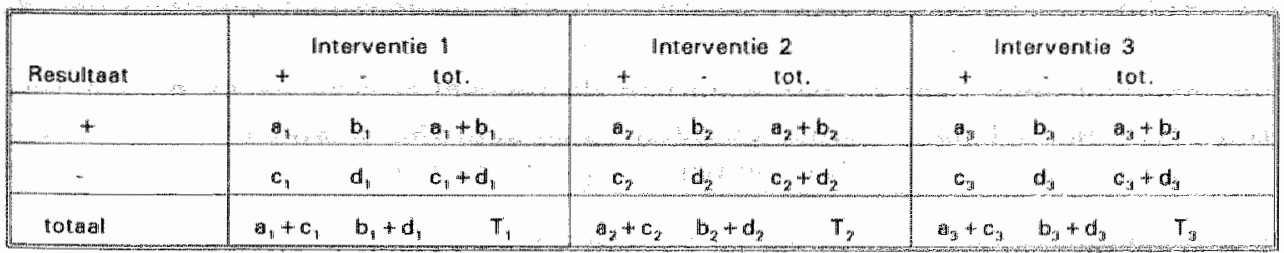


Als wij $a_{1}, a_{2}, a_{3}, \ldots$ voorstellen als $a_{3}$ krijgen wil het volgende voor het (gepoold) Relatief Risico en zifn $95 \%$ betrouwbearheidsinterval

$$
\begin{aligned}
& R R_{\text {mh }}=\frac{\sum a_{i}\left(b_{i}+d\right) / T_{i}}{\sum b_{i}\left(a_{i}+c_{i}\right) / T_{i}}
\end{aligned}
$$

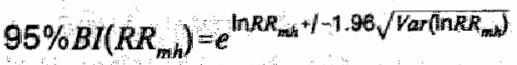

met als

$$
\operatorname{Var}\left(\ln R R_{m h}\right)=\frac{\sum\left(a_{i}+b_{j}\right)\left(a_{i}+c_{i}\right)\left(b_{i}+d_{j}\right) / T_{i}^{2}}{\left.\left[\sum \frac{a_{i}\left(b_{i}+d_{i}\right)}{T_{i}}\right] \sum \frac{b_{i}\left(a_{i}+c_{i}\right)}{T_{i}}\right]}
$$

Er bestaan analoge formules voor de berekening van Odds Ratio's en Relatieve Verschillen. (Rothman 1986, Kleinbaum e.a. 1988).

Hoewel dit nog met de hand is uit te rekenen, is het veel handiger om hiervoor terug te vallen op een computerprogramma. Naast de grote pakketten (BMDP,SAS,...) is dit tegenwoordig ook mogelijk met programma's op PC: Confidence Interval Analysis (CIA), ontworpen voor de berekening van betrouwbaarheidsintervallen (Gardner e.a. 1986), of Epi-Info, een epidemiologisch gericht, wrij copieerbaar programma, dat verdeeld wordt door Center of Disease Control in Atlanta (USA) en door de WHO (Dean e.a. 1990).

Wanneer onvoldoende originele gegevens in de oorspronkelijke studies opgenomen zijn, is thet niet mogelijk een gepoolide effectmaat te berekenen. Het is dan soms wel mogelijk om een gepoolde significantietest uit te voeren. Dit zegt uiteraard hiets over de grootle van een effect. Het staat de reviewer wel toe na te gaan of een verband al dan hiet aan toeval kan worden toegeschreven. Ook hiervoor zijn statistische technieken beschreven (Russell Teagarden 1989, Wolf 1986).

Wanneer in een deel van de oorspironkelijke studies voldoende originele gegevens opgenomen zijn en warneer op basis thiervan een gepoolde effectmaat berekend is, kan men niet uitgaan van de veronderstelling dat deze studies representatief zijn voor het geheel van alle verschenen studies. Trock, Lanza en Greenwald (Trock e.a. 1990 ) berekenden in een dergelijke situatie een (fictieve) schatting van de effectmat voor de overblijvende (case-control) studies, gebaseerd op een aantal veronderstellingen over de verdeling van de respectievelijke cases en controls. Deze veronderstellingen werden getoetst op de data van de studies waarvoor een wolledige gegevensset beschikbaar was. De methode bleek, althans in deze review, bruikbaar.

Het is echter zeer de vraag of dergelijke methoden een lang leven beschoren zullen zijn, gezien thet groot aantal veronderstellingen dat eraan ten grondslag ligt. 


\section{DEEL II}

\section{VERBETERING VAN DE AFNAMEKWALITEIT VAN CERVIXUITSTRIJKJES}




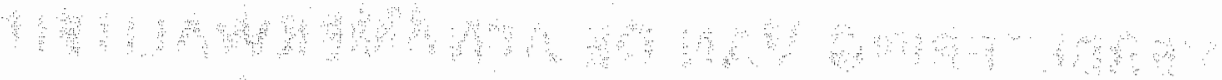

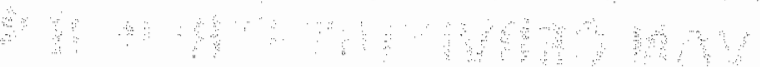




\section{HOOFDSTUK 4}

\section{CERVIXUITSTRIJKJES: AFNAMEGEWOONTEN EN ERVARINGEN}

Via een schriftelijke enquête onderzochten wij de gebruikte afnametechniek en de ervaringen bij het maken van cervixuitstrijkjes van 187 Vlaamse artsen, die allen met eenzelfde laboratorium samenwerken. Er was een respons van 134 artsen $(72 \%)$.

Het gebruik van de Cytobrush voor het afnemen van cervixuitstrijkjes dringt bij deze groep artsen geleidelijk door. Er blijken echter onvoorziene en ongewenste neveneffecten op te treden, zoals het gebruik van de Cytobrush alleen.

Voor geen van de gebruiketijke afnametechnieken zijn er problemen met de aanvaardbaarheid.

De inhoud van dit hoofdstuk is een bewerkte versie van:

* Buntinx F., Crebolder H.F.J.M., Knottnerus J.A. Cervixuitstrijkjes: afnamegewoonten en ervaringen. Huisarts $\mathrm{Nu}^{1} 1991 ; 20: 13-16$. 


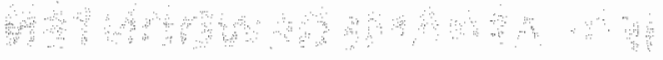

$$
\text { क्सिक्षिक्ष }
$$

4. $48+48+4$ 


\section{INLEIDING}

Oorspronkelijk gebruikte Papanicolaou voor het maken van vaginale uitstrijkjes een glazen pipetje met een rubberen peer en de uitstrijkies werden afgenomen ter hoogte van de fornix posterior van de vagina (Papanicolaou 19411. Ondertussen is de techniek geperfectioneerd en werden tientallen nieuwe afname-instrumenten ontwikkeld, sommige met zeer exotische vormen. Enkele hiervan doorstonden de tand des tijds. Zij lijken een duidelijke meerwaarde te bieden wat betreft de ermee vervaardigde uitstrijkjes. Vooral de combinatie van een Spatel van Ayre of een gecombineerde spatel met de Cytobrush, een borsteltje voor endocervicale afname, lijkt een aanwinst (Boon e.a. 1986, Deckert e.a. 1988, Reismann 1988). De hiermee vervaardigde uitstrijkjes bevatten vaker endocervicale cellen en er zijn minder vals negatieve resultaten.

Door het Centraal Laboratorium te Antwerpen werden alle meewerkende artsen in 1983 via een rondschrijven over de Cytobrushtechniek geïnformeerd. Het nodige materiaal wordt ter beschikking van de geïnteresseerde artsen gesteld. Er wordt echter geen standaard-afnametechniek opgelegd. Wij vroegen ons af in hoeverre deze nieuwe techniek in de groep van medewerkende artsen reeds tot de dagelijkse praktijkvoering doorgedrongen is en wat de ervaringen ermee zijn.

\section{METHODE}

Begin 1987 werd een vragenlijst bezorgd aan alle 187 artsen, die op dat ogenblik regelmatig samenwerkten met de cytologische dienst van het Centraal Laboratorium in Antwerpen.

Er waren twee reeksen vragen. De eerste reeks had betrekking op het laatste effectief afgenomen uitstrijkje en bevatte vragen over de afname en fixatietechniek en over het bloedverlies. De tweede vroeg de Cytobrushgebruikers naar hun ervaringen met Cytobrushgebruik in vergelijking met vroeger gebruikte methoden. Aan niet-Cytobrushgebruikers werd gevraagd naar redenen woor het nietgebruik ervan, respectievelijk voor het stoppen ermee.

Voor de vergelijkingsvraag diende men verschillende items te scoren op een schaal van $51=$ veel minder dan vroeger $)$ tot +5 (= veel meer dan vroeger $)$. Bij de verwerking werden de antwoorden hierop gegroepeerd. De andere vragen waren opgesteld volgens een multiple choice systeem.

Bij de analyse van het verband tussen de mate van bloedverlies en de gebruikte afnametechniek vond statistische analyse plaats door middel van de Chi ${ }^{2}$ test voor onafhankelijke proporties en $95 \%$ betrouwbaarheids Intervallen (Avonts e.a. $1988 \mathrm{~b}$ ).

\section{RESULTATEN}

De vragenlijst werd aan 187 artsen toegestuurd. Hiervan stuurden 134 artsen de vragenlijst anoniem ingevuld terug $(72 \%)$. Er werden geen aanmaningen gestuurd. De groep bestaat overwegend uit huisartsen. De geografische verdeling van de 
artsen die de vragenlijst terugstuurden komt overeen met de provincieverdeling van alle met dit laboratorium meewerkende artsen, met uitzondering van enige onder. vertegenwoordiging voor de Brabanders:

\section{Met betrekking tot het laatst gemaakte uitstrijkje}

\section{Materiaal gebruikt voor het uitstrijken}

Voo 75 van de $134(56 \%)$ artsen is de Cytobrush de gebruikelijke afnametechniek, meestal in combinatie met de Spatel van Ayre.

\section{Tabel 4.1: Gebruikt afnamemateriaal}

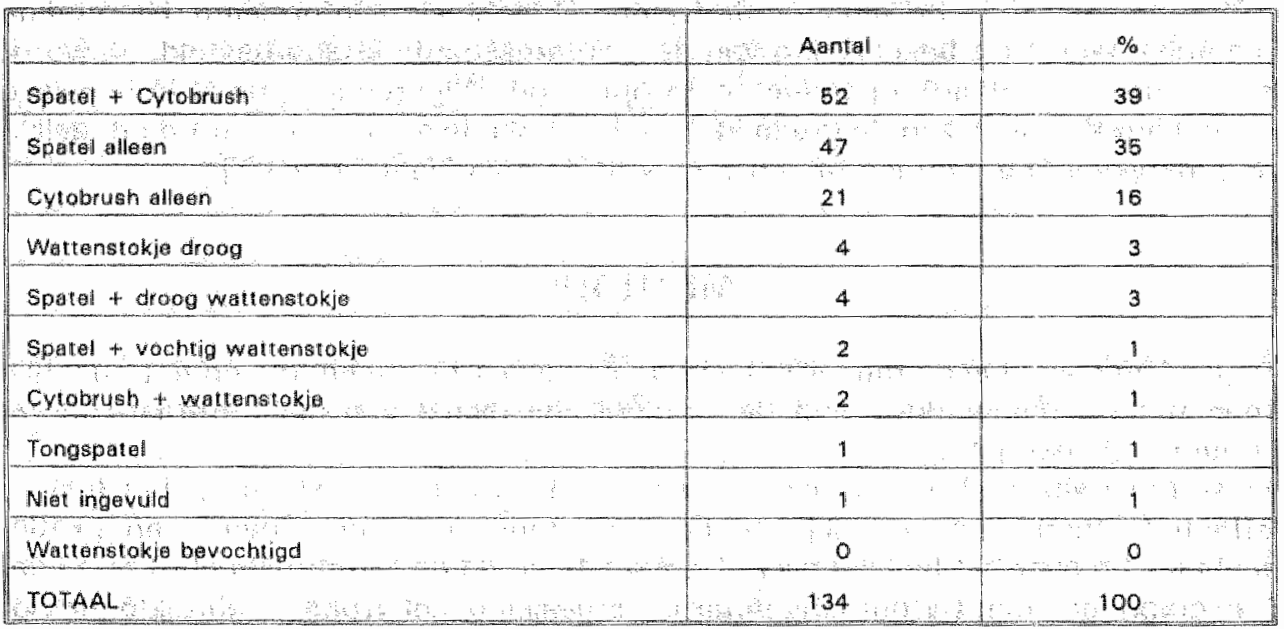

\subsection{Fixatiemethode}

Negentig procent (121/134) van de artsen maakt gebruik van de door het laboratorilum ter beschikking gestelde spray.

1.3. Verband tussen bloedverlies na het uitstrijken en het gebruikte materiaal Er werd gevraagd naar de ervaringen bij het laatst afgenomen uitstrijkje. Enkele collega's gaven daarbij spontaan een overzicht van wat zij doorgaans zien. In dat geval werd bij de verwerking de mogelijkheid gebruikt, die als het vaakst voorko. mend genoemd wordt.

Litgesproken bloedverlies na de afname wordt door $10 \%$ van de artsen genoemd. zonder dat één methode dit opvaltend vaker vertoont. Slechts in 3 gevallen $(2 \%)$ leidde bloedverlies tot klachten van de patient.

Cytobrushgebruik lijkt volgens de antwoorden van deze artsen wel gemakkelijker dan enige andere methode aanleiding te geven tot het verlies vam enkele druppels bloed. Dit is statistisch slechts significant voor de afnames waarbil de Cytobrush alleen gebruikt wordt ltabel 4.2 ). 
Tabel 4.2: Mate van bloedverlies volgens gebruikt afnamemateriaal

\begin{tabular}{|c|c|c|c|c|c|c|}
\hline Bloedwerliesi & $\begin{array}{l}\text { Spatel wan } \\
\text { Ayre t } \\
\text { Cytobrulsh }\end{array}$ & $\begin{array}{l}\text { Allem } \\
\text { Cytobrush }\end{array}$ & $\begin{array}{l}\text { Allean } \\
\text { Spatel van } \\
\text { Apro. }\end{array}$ & $\begin{array}{l}\text { Combina- } \\
\text { thes met } \\
\text { watren. } \\
\text { stokje }\end{array}$ & Total & 9150 \\
\hline Geem & $\begin{array}{c}11 \\
|2196|\end{array}$ & $\begin{array}{l}4 \\
19 \% \\
\end{array}$ & $\begin{array}{r}18 \\
(3796) \\
\end{array}$ & $86 \%$ & $\begin{array}{l}44 \\
43196 \\
\end{array}$ & $23 \cdot 40$ \\
\hline Enkele druppeis & $\begin{array}{r}32 \\
160 \%\} \\
\end{array}$ & $\begin{array}{l}15 \\
71 \%\end{array}$ & $\begin{array}{c}26 \\
153 \% \\
\end{array}$ & $(330)$ & $\begin{array}{l}77 \\
(570401\end{array}$ & $46: 66$ \\
\hline Uitglesproken & $\begin{array}{l}7 \\
(14 \%)\end{array}$ & $\begin{array}{c}2 \\
110 \%\end{array}$ & $\begin{array}{l}4 \\
(8 \%)\end{array}$ & $0 \%$ & $\begin{array}{l}13 \\
19 \%\end{array}$ & $5 \div 16$ \\
\hline Andere & $\begin{array}{l}2 \\
(4 \%)\end{array}$ & $\begin{array}{l}0 \\
(0 \%)\end{array}$ & $\begin{array}{l}1 \\
12 \% 1\end{array}$ & $10 \%$ & $\begin{array}{l}3 \\
(2 \%) \\
\end{array}$ & $0=7$. \\
\hline Totasl & 52 & $2 \pi$ & 49 & 12 & 134 & \\
\hline
\end{tabular}

\section{Vergelijking met vroeger gebruikte methoden}

\subsection{Ervaringen met de Cytobrush tio.v. vroeger gebruikte methoden}

Van 73 artsen die alls regel de Cytobrush gebruiken, beschikken wij over een score van hun ervaringen nu in vergelijking met de situatie zoals die bestond voor zij de Cytobrush gebruikten.

Vier procent van deze artsen vind thet gebruik van de Cytobrush technisch moeilijker dan de vroeger gebruikte methode. $75 \%$ vindt het nu gemakkelijker. De rest merkt weinig verschil.

Twaalf procent van de artsen vind het bloedverlies met de Cytobirush vergelijkbaar met vroeger, $29 \%$ vindt het nu minder en $59 \%$ vindt het nu meer uitgesproken. Volgens $83 \%$ van de artsen zou het gebruik van de Cytobrush voor hun patienten niet extra belastend zijn en slechts één arts meldt speciale problemen om de methode door patiënten te laten aanvaarden.

Slechts: $24 \%$ van de ondervraagde artsen vindt dat Cytobrushgebruik meer tijd kost dan de vroegere methode. Daarbij is er geen statistisch significant versohil aantoonbaar tussen artsen die bljkens hun antwoord op de eerste vragen alleen een Cytobrushafname maken en artsen die een uitstrijkje met de spatel van Ayre combineren met een Cytobrushafname

\subsection{Niet-gebruikers}

Van de artsen die als regel geen Cytobrush gebruiken, zijn er $39(64 \%)$ met de techniek bekend en $28 \%$ heeft de methode ooit gebruikt.

\section{2.1. WAAROM HEEFT MEN HET GEBAUIK VAN DE CYTOBIPUSH GESTOPT?}

Wij kregen 27 antwoorden op de vraag waarom artsen die de Cytobrush ooit gebruikten, daar later van afzagen (sommige artsen gaven meer dan 1 antwoord). In 12 gevallen slaat de reden op problemen met de (nieuwe) techniek: extra bloedverlies $(7 x)$, moeilijker aframeprocedure $(3 x)$, klachten van patiénten $(1 x)$ of 
grotere tijdsinvestering $11 \times 1$. Volgens de overblivende antwoorden waren de betrokken artsen gevwoon vergeten nieuw materiaal te bestellen of te gebruiken $(10 x)$ ofwel waren zif zelf van oordeel dat er geen echte reden voor het stoppen was $(5 x)$.

\subsubsection{WAAROM NOOIT GEBRUIKT?}

Op de vraag waarom artsen de techniek nooit gebruilkten, kregen wil 36 antwoorden. Daarvan verwizen er 32 naar afwezigheid van of gebrek aan informatie over deze methode.

Drle artsen vermelden angst voor het nieuwe en onbekende en én arts vreest dat de patièten meer last zouden ondervinden.

\section{DISCUSSIE}

Een antwoordpercentage van $72 \%$ wordt voor een schriftelijke vragenlijst onder artsen als heel behoorlik beschouwd. Dit gunstige resultaat werd wellicht in belangrijke mate beinvloed door het feit dat deze artsen zich sterk betrokken voelen bij "'hun" laboratorium, door de geringe omvang van de vragenlijst, door het gemak van invulten (bijna uitsluitend kruisjes zetten) en doordat de formulieren werden opgehaald via de eigen ophaaldienst van het laboratorium.

Onze gegevens komen van de ondervraging van artsen, die allemaall samenwerken met eenzelfde cytologisch laboratorium. Uiteraard beperkt dit de generaliseerbaarheid van de resultaten. Toch geven zij een interessant inzicht in de ervaringen van een vril grote groep artsen. Bij de evaluatie van onze resultaten blift de vraag of alle artsen zich wel genoeg herinnerden over hun laatste vitstrijkje; voor sommige van hen is dit zeker geen dagelijkse handeling. Er moet ook gedacht worden aan de mogelijkheid dat sociaal wenselijke antwoorden gegeven werden. Dit wordt in belangrijke mate voorkomendoor de anonimiteit van de antwoorden. Het is daarenboven helemaal niet duidelijk wat op dit vlak als sociaal wenselijk beschouwd wordt. De combinatie van de spatel van Ayre met de Cytobrush is de afnametechniek, die volgens deze studie door de meeste artsen gebruikt wordt. Het is ook de methode die door het betrokken laboratorium - en door de meeste auteurs op dit gebied hoe langer hoe meer aanbevolen wordt. Dat $35 \%$ van de artsen zich tot de Spatel van Ayre beperkt is niet zo opzienbarend. Artsen missen een belangrijk deel van de nieuwe kennis die hun via allerhande teksten aangeboden worden, mede omdat er dageliks ook veel irrelevante informatie in hun brievenbus glijdt. Bovendien hebben artsen meestal tijd nodig om aan nieuwe technieken te wennen.

Van de ondervraagde artsen blijken er $22136 \%$ van de niet - gebrukers en $16 \%$ van alle artsen die de enquete beantwoordden) de afnamemethode met de Cytobrush niet te kennen. Dit ondanks het feit dat het laboratorium in de afgelopen 5 jaar diverse brieven stuurde om de aandacht hierop te vestigen. Dit alles bevestigt de waarde, maar ook de beperkingen van schriftelijke informatie voor artsen. Misschien kan dit verbeterd worden door de betrokken informatie niet alleen regelmatig te herhalen, maar ook geïndividualiseerd aan te bieden.

Opvallend is dat $16 \%$ van de ondervraagde artsen aangeeft de Cytobrush alleen te gebruiken. Blijkbaar is hier sprake van een misverstand. Uit eigen onderzoek blijkt 
het vervangen van de spatelafname door een afname met de Cytobrush alleen geen volwaardige methode (zie deel III van dit proefschrift).

Uit zowat alle studies blijkt dat Cytobrushgebruik gemakkelijker leidt tot enige druppels bloedverlies (Boon e.a. 1986). Dat wordt hier bevestigd bil de beschrijving van de ervaring met het laatst afgenomen uitstrikje. Enig bloedverlies wordt gemeld in $71 \%$ bij Cytobrushgebruik en in $60 \%$ bij de Spatel-Cytobrushcombinatie versus $57 \%$ voor alle methodes samen. Uitgesproken bloedverlies is echter niet frequenter dan bij andere methoden. Van de 17 artsen die ooit met de Cytobrush werkten, maar ermee stopten, zijn er 7 die dit toeschrijwen aan extra bloedverlies met deze methode. Het is uiteraard niet mogelijk enig zicht te krijgen op de mate waarin dit berust op reële ervaringen dan wel op rationalisaties.

Artsen die met de. Cytobrush werken, blijken daar weinig problemen mee te ondervinden. Technisch is het gemakkelijk $(95 \%)$. De patienten hebben er geen last van $(83 \%)$ en zouden de methode zonder problemen $(98 \%)$ accepteren. Alleen de tijdsfactor kan een nadeel zijn (Boon e.a. 1986), maar ook dit wordt hier zelden genoemd. 
औि $\quad$ क :

$\therefore \quad \therefore$

का द व क्य

क् $\cdots$

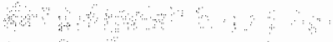

की

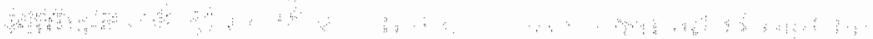

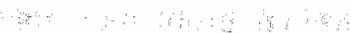

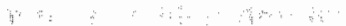

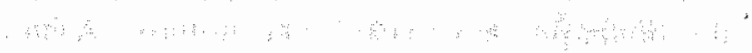

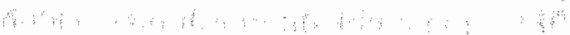




\section{HOOFDSTUK 5}

\section{AFNAMEKWALITEIT VAN CERVIXUITSTRIJKJES: EEN BESCHRIJVEND ONDERZOEK}

In deze studie analyseren wij op basis van het microscopisch beeld de kwaliteit van 4.362 opeenvolgende uitstrijkjes gemaakt door 238 artsen volgens een aantal vooraf gedefinieerde kenmerken. De gevonden resultaten, samen met het aantal en hetpercentage afwijkende uitstrijkjes, worden gecorreleerdmet beroepskenmerken van de uitstrijkende artsen.

De discipline (huisarts of gynaecoloog) en het geslacht van de uitstrijkende arts hangen sterk samen met het per arts gemaakte totaal aantal uitstrijkjes in de onderzoeksperiode en met het percentage pathologische uitstrijkjes. Het al dan niet voorkomen wan endocervicale cellen wordt vooral bepaald door het gebruikte afnamemateriaal. De kwaliteit van de fixatie is positief gecorreleerd met het totaal aantal uitstrijkjes. Het aantal uitstrijkjes met teveel celhoopjes, met te weinig epitheelcellen of met storende tekens van infectie blijft ruim onder de 1 procent.

De inhoud van dit hoofdstuk is een bewerking van:

* Buntinx F., Crebolder H.F.J.M., Essed G.G.M., Knottnerus J.A. Afnamekwaliteit van cervixuitstrijkjes: Een beschrijvend onderzoek. Huisarts Wet 1991; 34: 457 461. 


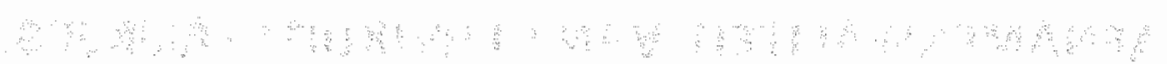

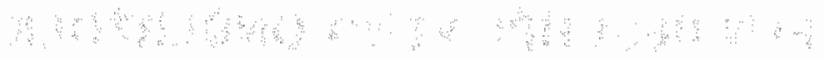

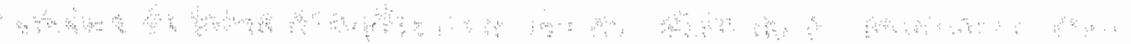

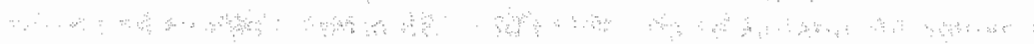

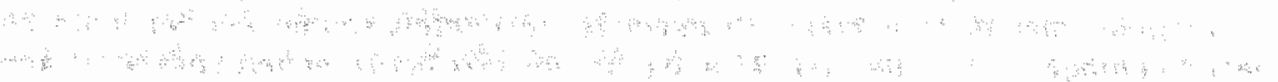

m.

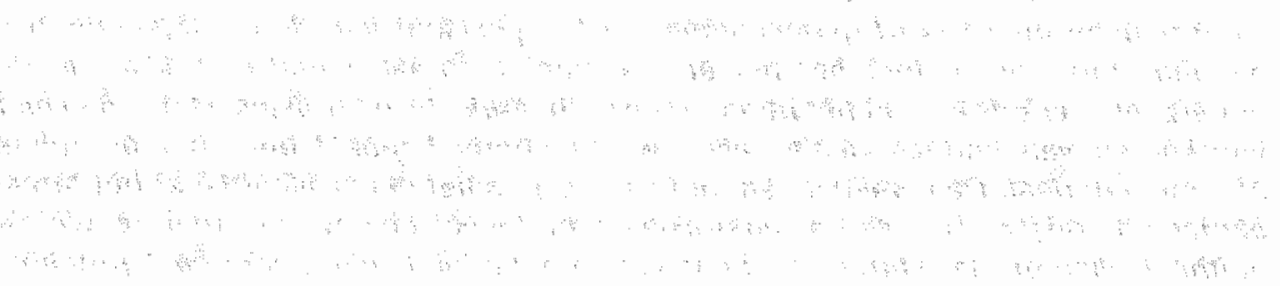




\section{INLEIDING}

De waarde van cervixuitstrijkjes voor de secundalire preventie van het cervixcarcinoom wordt beinvloed door verschillende factoren (Koss 1989, Richart 1979, Zuna 1984, Greening 1985, Steiner 1989/. Uiteraard is het van primair belang dat de risicopopulatie ook bereikt wordt. Daarnaast zijn een kwalitatief goede afname, een correct cytologisch onderzoek, een snelle en relevante rapportage en een adequate follow-up essentiële vereisten. Samen vormen zij een ketten waarvan de zwakste schakel de sterkte bepaalt.

In deze bijdrage richten wij ons op de afnamekwaliteit. Een beschrijvend onderzoek werd opgezet om basisinformatie te verzamelen voor een interventiestudie naar methoden ter verbetering van de afnamekwaliteit. Hiervoor analyseerden wij op basis van het microscopisch beeld de afnamekwaliteit van alle uitstrijkjes, gemaakt door 238 Vlaamse artsen gedurende een periode van drie maanden. Hiermee wordt beoogd te beoordelen op welke gebieden de kwaliteit van de uitstrijkjes nog voor verbetering vatbaar is.

Wij onderzochten daarbij ook welke kenmerken van de uitstrijkende arts en van de gebruikte techniek verband houden met deze kwaliteit.

In een eerdere analyse (Buntinx e:a. 1984) konden wij geen versehil aantonen in het percentagie endocervicale cellen in uitstrijkjes, gemaakt door huisartsen en gynaecologen. Dit resultaat komt overeen met niet gepubliceerde ervaringen, die ons uit verschillende laboratoria meegedeeld werden. In een recente Amerikaanse studie werden zelfs vaker endocervicale cellen gevonden in de uitstrijkjes van family physicians dan in de uitstrijkjes van gynaecologen (Reisman 1988). Uiteraard spelen verschillen tussen de populaties die huisartsen, respectievelijk gynaecologen bezoeken, hier een rol. Omdat hierover geen verdere publicaties gevonden werden, wilden wij de kwaliteitsverschillen tussen huisartsen- en gynaecologenuitstrijkjes nu verder uittesten op een groter alantal uitstrijkjes en voor verschillende kwaliteitsindicatoren.

Over de invloed van de uitstrijkervaring op de afnamekwaliteit werd door Vooijs (Vooijs e.a. 1986) uitvoerig gerapporteerd. Zijn registraties hebben echter voornamelijk betrekking op professionelle screensters uit het (vroegere) Nederlandse systeem van bevolkingsonderzoek. Onze registratie biedt een mogelijkheid om het verband tussen uitstrijkervaring en de kwaliteit van routine-uitstrijkjes van huisartsen en gynaecologen na te gaan.

Uiteraard waren wij geïteresseerd in het effect van opleiding op de afmamekwaliteit van uitstrijkjes. Daarom worden de universiteit en het jaar van afstuderen van de arts in de analyse betrokken.

Voorts werd nagegaan in welke mate het lidmaatschap van een Wetenschappelijke Vereniging (in dit geval de Wetenschappelijke Vereniging der Vlaamse Huisartsen) gecorreleerd is met de kwaliteit van (een onderdeel van) het dagelijks huisartsen. werk. Wij waren daarbij benieuwd of WVVH-leden al dan niet betere uitstrijkjes maken dan niet-leden. Ook het geslacht van de uitstrijkende arts werd in de analyse betrokken, vooral omdat wij het niet onaannemelijk vonden dat vrouwelijke artsen meer uitstrijkjes maken en misschien ook vaker pathologie detecteren dan hun mannelijke collega"s. 
Er is in de literatuur veel gepubliceerd over verschillen in afnamekwaliteit van uitstrijkjes die volgens verschillende technieken gemaakt worden. Vooral voor het vinden van endocervicale cellen zou dit een belangrije rol spelen (Boon e.a. 1986, Kristensen e.a. 1989/. In deze studie wilden wij daarom ook het verband nagaan tussen de gebruikte afnamemethode en de verschillende kwaliteitsindicatoren.

\section{METHODE}

Met ingang van 1 juni 1989 werd van leder aangeboden uitstrijkje door de dienst Anatomopathologie van het Centraal Laboratorium te Antwerpen een gedetailleerde kwaliteitsbeoordeling gemaakt. Daarbij werd op een driepuntssichaal een algemeen kwaliteitsoordeel gegeven, alsmede een specifieke beoordeling van respectievelik de celrijkdom wan het preparaat, het voorkomen van slecht beoordeelbare celhoopjes, het aantal endocervicale fof metaplastischel cellen, de kwalitelt van de fixatie en het eventueel voorkomen van ontstekingsverschijnselen: Dit oordeel werd niet aan de uitstrijkende arts meegedeeld.

De volgende criteria werden gebruikt voor de beoordeling goed:

- Endocervicale cellen aanwezig of squameuse metaplasie aanwezig.

- Fixatie goed resultaat, beoordeeld volgens de aftekening van de celstructuren. de kleurbaairheid en de netheid van het preparaat.

Celrijkdom: voldoende epitheicellen aanwezig.

- Celhoopjes: niet of slechts sporadisch voorkomen van een slecht beoordeelbaar celgroepje.

- Infectietekens: geen tekens van ontsteking aanwezig in dergelijke mate dat de beoordeling van het preparaat erdoor bemoeilijkt wordt.

- De algemene kwaliteitsbeoordeling is goed als er endocervicale of metaplastische cellen aanwezig zijn en als de andere items tenminste met 2 gescoord worden op een driepuntsschaal.

Bij deze analyse werden de uitstrijkjes verwerkt van alle Nederlandstalige artsen die in de loop van het voorgaande jaar 11988 ) tenminste 10 uitstrijkjes voor cytologisch onderzoek aanboden $(n=238$ ). De selectie op basis van het aantal uitstrijkjes werd ingebouwd teneinde vertekening van de resultaten door toevallige inzenders te voorkomen. Hierbij werden 76 artsen uitgesloten.

De resultaten uit deze tekst slaan op de uitstrijkjes die verwerkt werden tijdens de maanden juni, juli en augustus 1989 ( $n=4362$ ).

Alle vitstrijkjes werden in eerste instantie beoordeeld door 4 laboranten: De toewijzing vond plaats in volgorde van binnenkomst. Afwijkende en twijfellachtige uitstrijkjes werden opnieuw beoordeeld door de hoofdlaborante en door een patholoog anatoom en thun oordeel werd als definitief resultaat gehanteerd. In het betrokken laboratorium worden jaarlijks ongeveer 25.000 uitstrijkjes beoordeeld.

Onze gegevens hebben betrekking op 238 artsen. Daarbij zijn 222 huisartsen en 16 gynaecologen. 
Onder de huisartsen zijn 180 mannen en 42 vrouwen. Onder de gymaecologen zijn 14 mannen en 2 vrouwen.

Van de 222 huisartsen zijn er $106(48 \%)$ lid van de WVVH, zeven daarvan worden door de vereniging omschreven als zijnde actief betrokken bij werkgroepen en commissies. Van alle Vlaamse huisartsen is ongeveer $27 \%$ lid van de WVWH.

Alle artsen werden bij het begin van het onderzoek telefonisch ondervraagd over het door hen gebruikte materiaal bij het vervaardigen van een uitstrijkje. Van 230 $(97 \%)$ verkregen wij een volledig antwoord. De 8 artsen, waarvan deze gegevens niet bekend zijn, worden weggelaten als de afnamemethode bij de analyse ter sprake komt.

Voor elke arts afzonderlijk werden per kwaliteitskenmerk de percentages berekend van alle beoordeelde uitstrijkjes die voor het betrokken kwaliteitskenmerk de beoordeling goed kregen. Deze percentages, samen met het aantal en het percentage pathologische uitstrijkjes, worden in onze analyse verwerkt en vergeleken met verschillende artskenmerken: geslacht, discipline (huisarts of gynaecoloog), universiteit en jaar van afstuderen, lidmaatschap van de Wetenschappelijke Vereniging der Vlaamse huisartsen (WVVH), aantal uitstrijkjes geproduceerd in het voorafgaande jaar en het gebruikte afnamemateriaal. De kwaliteitsbeoordelingen werden voor deze analyse gedichotomiseerd (goed of slecht).

Het percentage uitstrijkjes van goede kwaliteit voor een bepaald criterium is het aantal uitstrijkjes met een kwaliteitsoordeel "goed" voor het betrokken criterium, gedeeld door alle beoordeelde uitstrijkjes.

Het gemiddelde van de percentages uitstrijkjes van goede kwaliteit woor een bepaald criterium per arts is de som van de percentages uitstrijkjes met een kwaliteitsoordeel "goed" voor elke arts afzonderlijk, gedeeld door het totaal aantal artsen.

De gevonden verbanden werden getoetst met een $\mathrm{Chi}^{2}$ toets voor twee catego rische variabelen en met een Mann-Whitney toets of een Kruskall-Wallis toets voor het verband tussen een categorische (met twee, respectievelijk meer dan twee klassen) en een numerieke variabele. $p<0.05$ werd gebruikt als (tweezijdige) significantiegrens. Waar een p-waarde aangeduid wordt zonder vermelding van de gebruikte toets, is éen van de beide laatst vermelde toetsen gebruikt.

Teneinde bij het verband tussen de aanwezigheid van endocervicale cellen en de afnamemethode te controleren voor een eventuele beinvloeding door de discipline van de uitstrijkende arts, werd een multiple lineaire regressie uitgevoerd. Daarbij was het percentage uitstrijkjes met endocervicale cellen per arts de afhankelijke variabele. Als onafhankelijke variabelen werden ingevoerd die discipline en de afnametechniek met behulp van 4 dummy-variabelen.

\section{RESULTATEN}

\section{De artsen}

Ruim driekwart van de artsen is afgestudeerd aan de Leuvense Universiteit. De andere artsen zijn afkomstig van diverse andere universiteiten. Het aantal jaren 
praktikervaring, gebaseerd op het jaar van afstuderen, varieent van 1 tot 46 . Het gemiddelde is 16 jaar (SD: 10). De mediaan ligt op 13 jaar. Mannelijke artsen zijn gemiddeld eerder afgestudeerd dan vrouwelijke $(p<0.001)$.

$142(62 \%)$ artsen blikken als regel zowel een endocervicale als een ectocervicale uitstrijk te maken. 77 (33\%/ nemen als regel hetzij 1 uitstrijk, hetzil 2 uitstrijken volgens dezelfde techniek. Bif 11 artsen $(5 \%)$ is de gebruikte afnametechniek afhankelijk van het klinisch beeld of van de omstandigheden. Opvallend is dat 44 artsen $(19 \%)$ gebruk maken van de Cytobrush alleen (tabel 5.1$)$.

Tabel 5:1: Afnamemateriaal gebruikt voor het maken van cervixuitstrijkjes

\begin{tabular}{|c|c|c|c|}
\hline . & 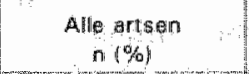 & $\begin{array}{c}\text { Huhsartenten } \\
n\end{array}$ & $\begin{array}{c}\text { Gynaeicologen } \\
\text { n }\end{array}$ \\
\hline Spatell t Cytobrush & $72(30)$ & 69 & 3. \\
\hline Spatel goherp + gtomp & $64(28)$ & 64 & 0 \\
\hline Cytoburush alleon & $44(19)$ & 38 & 6 \\
\hline 1 Spatellat name & $29(13)$ & 27 & 2 \\
\hline Diwersen:- & 21191 & 19 & 2 \\
\hline Total & 230110001 & 217 & 13 \\
\hline
\end{tabular}

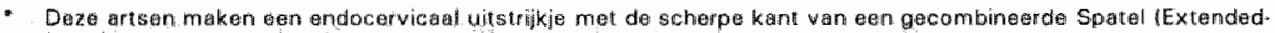

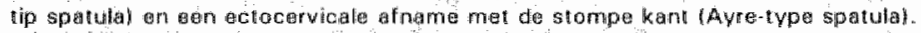

- indar aner Spatel + Watteristok $(9 \times)$ en Wattenstok allewen $(2 x)$

\section{Totaal aantal uitstrijkjes per arts}

De betrokken artsen produceerden gedurende deze drie maanden gemiddeld 18.5 uitstrijkjes $(\mathrm{SD}=38.8)$.

Voor de huisartsen was dit gemiddelde 12 , woor gyraecologen $113(p=0.008)$. Bij de huisartser makten WVVH-leden gemiddeld 14 uitstrijkjes en niet-leden 9 $p=0.001)$.

Zoals te verwachten is er een duidelijk verband tussen het aantal uitstrijkjes dat door een arts ingestuurd wordt gedurende deze 3 maanden en het totaal aantal uitstijkjes in 1988 (p $<0.001$ ).

Vrouwelijke artsen en met name vrouwelijke huisartsen maakten meer uitstrijkjes dan hun mannelijke collega"s: gemiddeld 20.3 en 18.0 versus 18.1 en 10.3 p $=$ 0.002 in beide gevallen). Patiënten die hun uitstrijkje bij een vrouwelijke arts laten maken zijn gemiddeld jonger dan de patiënten van mannelijke artsen Chi $^{2}$ " $p<$ 0.0011 .

Er is geen statistisch significante invloed van het jaar of de universiteit van afstuderen van de arts. 


\section{Endocervicale cellen}

Tussen 4.362 uitstrijkjes zijn er $3.478 \quad(79.7 \%$ waarin endocervicale en/of metaplastische cellen gevonden worden. De helft van de artsen heeft geen endocervicale cellen in tenminste $10 \%$ van zijn uitstrijkjes. Drie artsen $(1.3 \%)$ hebben in geen van hun uitstrijkjes endocervicale cellen. Bij 74 artsen $(31.9 \%)$ worden deze cellen in alle uitstrijkjes gevonden. Er is een duidelijk verband tussen het afnamemateriaal en het al dan niet aanwezig zijn van endocervicale cellen (tabel 5.2).

Tabel 5.2: Gemiddelde van de percentages uitstrijkjes met endocervicalle cellen per arts volgens het gebruikt afnamemateriaal

\begin{tabular}{|c|c|}
\hline Afnamemateriaal & $\begin{array}{c}\text { Semiddeld \% utstrijkies met ondocervicale } \\
\text { cellen per arts }\end{array}$ \\
\hline Spatel + Cytobrush & 87.9 \\
\hline Cytobrush alleen & 86,3 \\
\hline$\therefore \quad 4 \quad \cdots$ & 82,4 \\
\hline Spetel scherp + stomp & 76.6 \\
\hline ispatelafname & 72.6 \\
\hline
\end{tabular}

Kূruskall Wallis, $p=0,005$

Er is geen verband gevonden met de leeftijd van de patiënten ( $p=0.07)$, het geslacht van de arts, zijn discipline, de universiteit waar of het jaar waarin hij/zij afstudeerde. Er is ook geen relatie met het aantal uitstrijkjes gemaakt in het voorafgaande jaar. Voor de subgroep huisartsen zijn de resultaten vergelijkbaar. Er wordt bij de huisartsen geen duidelijk verschil gevonden tussen WVVH-leden en niet-leden.

De resultaten van dle uitgevoerde regressie waren als volgt :

De vitstrijkjes afgenomen met de Cytobrush en met de combinatie valh Spatel + Cytobrush scoren wat betreft het voorkomen van endocervicalle cellen, na correctie voor de discipline van de uitstrijkende arts, significant beter dan de uitstrijkjes. op basis van een spatelafname. De verbetering in het percentage uitstrijkjes met endocervicale cellen, na correctie woor de discipline, bedraagt $13 \%$ (Cytobrush). respectievelijk $15 \%$ ispatel + Cytobrush) ten opzichte van de spatelafname. De twee andere afnamemethoden scoren niet significant verschillend ten opzichte van de spatelafname.

\section{Kwaliteit van de fixatie}

De kwaliteit van de fixatie is over het algemeen zeer goed: gemiddeld geeft slechts $2 \%$ van alle uitstrijkjes problemen op dit gebied. Gynaecologen blijken iets vaker 
goed te fixeren dan huisartsen: respectievelik gemiddeld $97.6 \%$ versus $96.4 \%$ goed gefixeerde uitstrijkjes $(p=0.003)$.

Het verband tussen het aantal uitstrijkjes met een onbevredigende fixatie en het aantal uitstrijkjes in het vorige jaar heeft de vorm van een omgekeerde $U \backslash p=$ 0.091 ).

De kwaliteit van de fixatie is niet gecorreleerd met het geslacht van de arts, de universiteit waar of het jaar waarin hij afstudeerde. Ook de leeftijd van de patiënten speelt geen rol.

\section{Andere kwaliteitskenmerken}

Storende tekenen van inflammatie, celhoopjes of een te laag aarital epitheelcellen komen voor in minder dan $1 \%$ van de uitstrijkjes.

Voor beide laatste kwalliteitskenmerken is geen verband met de onderzochte artskenmerken aantoonbaar.

Huisartsen leveren lets meer uitstrijkjes met storende infectietekenen dan gynaecologen. Het verschil is statistisch significant $(p=0.006)$, maar klinisch niet van betekenis (gemiddeld respectievelijk $99.6 \%$ en $99.8 \%$ goede uitstrijkjes). Er is ook een statistisch significant, maar niet systematisch en dus moeilijk interpreteerbaar verband met het aantal praktijkjaren $(p=0.03)$ en het aantal uitstrijkjes, gemaakt in 1988 ( $p<0.001)$. In de subgroep huisartsen wordt dit verband niet gevonden. Er is geen verband aantoonbaar met de andere onderzochte artskenmerken.

\section{Pathologische cellen}

Het percentage afwijkende uitstrijkjes (Pap $\geq I I I)$ per arts varieert tussen 0 en $15 \%$; het absolute aantal afwijkende uitstrijkjes per arts over deze periode van drie maanden tussen 0 en 3. De verdeling in Pap-klassen is weergegeven in tabel 5.3. De leeftijd van de patiënten heeft hierop in onze reeks geen significante invloed.

Tabel 5.3: De verdeling van alle uitstrijkjes

\begin{tabular}{|c|c|c|}
\hline Paph wesese & Aantal & $\%$ \\
\hline 1 & 1.885 & 43.2 \\
\hline$\|$ & 2.444 & 56.0 \\
\hline E llita & 33 & 0.8 \\
\hline
\end{tabular}

Vrouwelijke artsen vinden verhoudingsgewijs meer pathologische uitstrijkjes dan hun mannelijke collega's (tabel 5.4). 
Tabel 5.4. Gemiddeld aantal en gemiddelde van de percentages afwijkende uitstrijkjes per arts. De percentages zijn betrokken op alle uits trijkjes per arts.

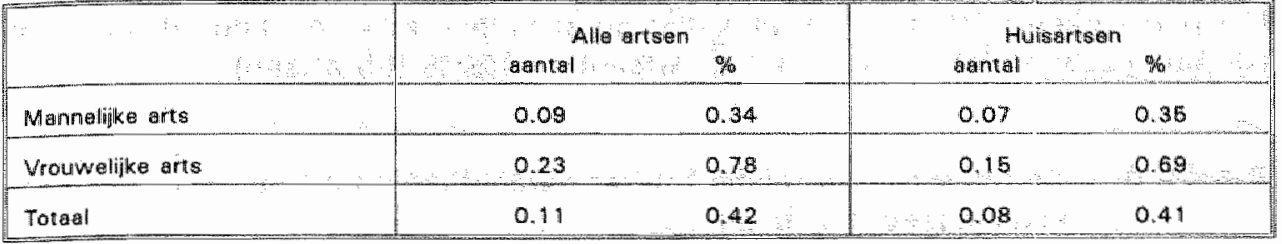

Mann-Witney $p=0.0073$ voor het aantal afwijkende uitstrijkjes en $p=0.0068$ voor het gemiddelde van de percentages (voor alle artsen).

Gynaecologen leveren zowel een hoger aantal $(p=0.0001)$ als een hoger percentage (gemiddeld $0.61 \%, p=0.003$ ) pathologische uitstrijkjes.

Het aantal afwijkende uitstrijkjes hangt sterk samen met het totaal aantal uitstrijkjes gemaakt tijdens het voorgaande jaar $(p=0.0001)$. Het percentage toont hiermee ook een statistisch significant verband in de vorm van een omgekeerde $U$, met maximale waarden bij een productie van 50-100 uitstrijkjes per jaar (tabel 5.5 ).

Tabel 5.5: Gemiddeld aantal en gemiddelde van de percentages afwijkende uitstrijkjes per arts als functie van het aantal uitstrijkjes gemaakt tijdens het voorgaande jaar.

\begin{tabular}{|c|c|c|}
\hline Aarutal uitstrijkjes in 1988 & $\begin{array}{l}\text { Gemicdeld aaniall } \\
\text { Pap } \geq \text { lll per arts }\end{array}$ & $\begin{array}{l}\text { Gemiddeld } \% \\
\text { Pap } \approx I I l \text { per arts }\end{array}$ \\
\hline$<20$ & 0.018 & 0.214 \\
\hline$<50$ & 0.022 & 0.110 \\
\hline$<100$ & 0.220 & 1.030 \\
\hline$<500$ & 0.286 & 0.746 \\
\hline$>500$ & 0.600 & 0.189 \\
\hline
\end{tabular}

Voor de subgroep huisartsen vinden wij vergelijkbare cijfers. Er is geen relatie met het WVVH-lidmaatschap.

Er is geen statistisch significant verband met de universiteit van afstuderen van de arts of met het aantal praktijkjaren. Ook voor het gebruikte afnamemateriaal kan geen significante relatie aangetoond worden.

\section{Algemeen kwaliteitsoordeel}

Er is een duidelijk verband tussen de afnamemethode en de algemene kwaliteits beoordeling $(p=0.0004)$. Hiermee volgt het algemeen kwaliteitsoordeel het 
patroon van de aanwezigheid van endocervicale cellen. De uitstrijkjes gemaakt met een Spatel 11 of 2 viteinden) krijgen een duidelijk lagere beoordeling (gemiddeld respectievelijk 70 en $71 \%$ goede uitstrijkjes per arts/ dan de uitstrijkjes gemaakt met Spatel + Cytobrush $(87 \%)$ of met Cytobrush alleen $(85 \%)$.

Het percentage uitstrijkjes per arts met de algemene kwaliteitsbeoordeling goed (zie tabel 5.6) varieert tussen $0 \%$ (5 artsen) en 100\% (65 artsen).

Tabel 5.6: Aantal artsen in relatie tot het percentage uitstrijkjes met algemeen kwaliteitsoordeel goed

\begin{tabular}{|c|c|c|}
\hline$\%$ Goede uitstrikjeg & Aantal artsen & $\begin{array}{r}\text { Cumulatief } \\
\text { Percentage } \\
\end{array}$ \\
\hline$\cdots$ & 5 & 2 \\
\hline 4.10 & 3 & 2 \\
\hline $11 \cdot 20$ & 3 & 3 \\
\hline $21 \cdot 30$ & 0 & 3 \\
\hline $31+40$ & 15 & 6 \\
\hline 41.60 & 14 & $\vdots$ \\
\hline $51-60$ & 12 & 17 \\
\hline $125 \quad 61.70$ & 31 & 30 \\
\hline $71-80$ & 30 & $\therefore \quad 43$ \\
\hline $91-90$ & 35 & 58 \\
\hline $91-99$ & 32 & 72 \\
\hline 100 & 65 & 100 \\
\hline Totad & 232 & 100 \\
\hline
\end{tabular}

Er is geen aantoonbaar verband met het geslacht van de arts, diens discipline, de universiteit of het jaar van afstuderen van de arts of het aantal uitstrijkjes in 1988. Voor huisartsen is er geen verband met het al dan niet lid zijn van de WVVH.

In tabel 5.7 vindt $U$ een samenvattend overzicht van de afnamekwaliteit van alle onderzochte uitstrijkjes, volgens de verschillende criteria.

\section{DISCUSSIE}

Al eerder werd beschreven (Boon e.a. 1986, Kristensen e.a. 1989) dat het percentage uitstrijkjes met endocervicale en/of metaplastische cellen erg wisselt van arts tot arts. In onze serie vinden wij voor het percentage uitstrijkjes met endocervicale cellen per arts een variatie van nul tot honderd procent. In overeenstemming met vroeger onderzoek (Buntinx e.a. 1984) vonden wij geen verband met de discipline van de arts (huisarts of gynaecoloog). Er werd ook geen verband aangetoond met 
Tabel 5:7: Uitstrijkjes van goede kwaliteit volgens de verschillende kwaliteits: kenmerken ( $n=4362$ ) aantal, percentage en gemiddelde van de percentages per arts

\begin{tabular}{|c|c|c|c|}
\hline $\begin{array}{c}\text { Kwalle } \\
\vdots \\
0\end{array}$ & $\begin{array}{l}\text { Aantial goede uit- } \\
\text { strikjes }\end{array}$ & $\begin{array}{l}\text { Patcentage goede uni- } \\
\text { strijkes }\end{array}$ & $\begin{array}{l}\text { Gomiddeste wan de } \\
\text { perantages gode } \\
\text { uitstrikjas por arts }\end{array}$ \\
\hline Endoucarvicale collen & 3478 & 79.7 & 82.0 \\
\hline Fixatie & 4280 & 98.1 & 96.5 \\
\hline Celhoopjes & $\quad 4355$ & 998 & 996 \\
\hline Ceirijkdom: & 4344 & 99.6 & 98.3 \\
\hline infectio & 4356 & 99.9 & 99.6 \\
\hline Pap $\geq 11$. & 33 & 0.8 & 0.4 \\
\hline
\end{tabular}

" berekend op het totaal wan alle anderzochto vitstrijkgs.

het aantal uitstrijkjes gemaakt tijdens het voorgaande jaar. Al eerder (Vooijs e.a. 1986) werd een verband gevonden tussen de uitstrijkervaring van professionele uitstrijksters uit het Nederlands bevolkingsonderzoek en hun percentage uitstrijkjes met endocervicale cellen. Het gaat daarbij echter om uitstrijksters, die elk een ervaring hebben van meerdere duizenden uitstrijkjes.

Er werd een sterk verband aangetoond tussen het percentage uitstrijkjes met endocervicale cellen en het gebruikte afnamemateriaal, waarbij de Cytobrush duidelijk betere resultaten geeft dan de andere instrumenten. Dit verband blijft behouden na correctie voor de discipline van de uitstrijkende arts. Deze resultaten stemmen overeen met de algemene tendens in de literatuur, zoals beschreven in hoofstuk 1 .

De discipline en het aantal uitstrijkjes gemaakt tijdens het voorgaande jaar hangen samen met de kwaliteit van de fixatie, die overigens in slechts $2 \%$ van alle uitstrijkjes onvoldoende blijkt.

Het percentage uitstrijkjes met teveel celhoopjes, met te weinig epitheelcellen of met storende infectietekenen is globaal lager dan $1 \%$. Zoals bij zulke lage percen: tages te verwachten is, zijn er geen duidelijke relaties met artskenmerken aantoonbaar.

Het percentage afwijkende uitstrijkjes in deze studie is lager dan gerapporteerd door een aantal Nederlandse auteurs. Onze cijfers zijn echter zeker miet lager dan elders in België. Ook in Nederland zijn er trouwens zeer grote verschillen tussen de verschillende centra. Op wereldschaal zijn deze verschillen nog groter.

De sterke variatie tussen artsen in percentage pathologische uitstrijkjes is wellicht ten dele te wijten aan het relatief lage aantal uitstrijkjes per arts dat ingestuurd werd over een periode van drie maanden. Een verwachte bevinding is dat gynaecow logen duidelijk meer afwijkende witstrijkjes afnemen dan huisartsem. Wellicht horen daar een aantal controles bij van patiënten die wegens een afwijkend uitstrijkje 
verwezen werden. Minder voor de hand liggend is dat vrouwelike artsen meer pathologie detecteren dan hun mannelijke collega's. Of zouden vrouwelijke artsen, althans woor gynaecologische problematiek, meer bereikbaar zijn voor vrouwen ut de risicogroepen londer meer oudere viouwen, vrouwen uit lagere sociale milieus en vrouwen met gynaecologische klachten??

Het is niet onverwacht dat artsen die meer uitstrijkjes insturen meer pathologie vinden, ook na correctie voor de discípline. Het percentage pathologische uitstrijk. jes echter is het hoogst bij artsen die tussen 50 en 100 uitstrijkjes per jaar afnemen. Een mogelijke verklaring hiervoor is dat er toch een minimumproductie nodig is om voldoende kwallteit te halen en de kans op het missen van pathologie zo klein mogelijk te maken. Bij een erg hoog aantal uitstrijkjes daarentegen kan de tijdsdruk een negatieve invloed hebben op de zorgvuldigheid bij de afname en zo op de kwaliteit. Hat is echter even goed mogelijk dat bij een (te?) hoge uitstrijkfrekwentie de risicogroep al "uitgezeefd" is, zodat het percentage pathologie daalt, of dat de hiler gevonden verschillen terug te voeren zijn op een relatie tussen het aantal uitstrijkjes dat een arts maakt en de mate waarin vrouwen uit de bekende risicogroepen door hem/haar gescreend worden.

Wij konden in dit onderzoek geen verband aantonen tussen de gebruikte afnametechniek en het percentage afwijkende uitstrijkjes. Dit kan betekenen, dat er een dergelijk verband niet bestaat. Het is echter ook mogelijk dat een bestaand verband vanwege het lage aantal afwijkende uitstrijkjes niet gevonden werd.

Wij hebben niet kunnen aantonen dat WVVH-leden betere uitstijikjes maken dan niet-leden. Wel maken huisartsen die lid zijn van de WVWH meer uitstrijkjes dan niet-leden. Het is niet duidelijk wat hiervoor de verklaring is : Misschien komt dit door een sterkere preventieve ingesteldheid van de leden, misschien ook voelen zij zich eerder alangetrokken tot het meer ambachtelijke deel van het huisartsenwerk. Omdat wij geen gegevens hebben over de verschillende praktijkgrootten, kunnen wij niet uitsluiten dat ook dit een rol speelt. Voor zover ons bekend is het de eerste maal dat een mogelijk verband tussen het lidmaatschap van een wetenschappelijke vereniging en kwaliteitsindicatoren getoetst wordt. Het lijkt ons dat een meer uitgebreide vergelijking van de verrichtingen van WVWH-leden en niet-leden voor de vereniging een boeiende vorm van kwaliteitscontrole kan betekenen.

De universiteit en het jaar van afstuderen van de arts lijken de afnamekwaliteit van cervixuitstrijkjes niet duidelijk te beïnvloeden.

Deze beschrijvende studie werd opgezet teneinde basisinformatie te verzamelen voor een project om de afnamekwaliteit van cervixuitstrijkjes te verbeteren. Daarbij zullen wij, afgaande op deze gegevens, vooral aandacht moeten hebben voor het voorkomen van endocervicale en metaplastische cellen en in mindere mate voor de $k$ waliteit van de fixatie. Hierin valt immers slechts weinig verbetering te bereiken. Ook het aantal en het percentage afwijkende uitstrijkjes per arts zal nauwlettend gevolgd worden. 


\section{HOOFDSTUK 6}

\section{VERBAND TUSSEN KWALITEITSKENMERKEN EN PATHOLOGIE BIJ CERVIXUITSTRIJKJES}

Met behulp van een logistische regressieanalyse anderzochten wij voor 17.664 cervixuitstrijkjes het verband tussen de aanwezigheid van pathologische cellen in een uitstrijkje enerzijds en de afnamekwaliteit anderzijds. De afnamekwaliteit werd beoordeeld volgens vijf op voorhand gedefinieerde criteria.

Onvoldoende fixatie blijkt geassocieerd met een zevenvoudige stijging van het percentage witstrijkjes met pathologische cellen, na correctie voor de leeftijd van de patiënte, woor de identificatie van de screenende labarante en voor de andere kwaliteitscriteria. Dit suggereert een sterk verhoogde kans op vals positieve witstrijkjes bij onvoldoende fixatie.

De andere variabelen die een significante bijdrage in de regressievergelijking opleverden, zijn het geboortejaar van de patiënte en de aanwezigheid van endocerwicale cellen.

Elementen uit dit hoofdstuk werden gepubliceerd als:

* Buntinx F., Crebolder H.F.J.M., Knottnerus J.A., Essed G.G.M. Cervical smear sampling quality (Letter to the editor). Lancet 1991; 337: 926-927. 


$$
\text { a } \quad \therefore \quad-\quad+3
$$

$\because \quad \therefore \quad$ a

$\because \quad$ या

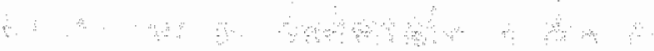

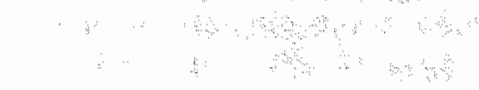




\section{INLEIDING}

Toen vijftig jaar geleden de techniek van de cervixcytologie ontwikkeld werd, was het cervixcarcinoom een frequente aandoening die jaarlijks vele vrouwen het leven kostte (Papanicolaou 1943).

Sinds het op grote schaal uitvoeren van cervixuitstrijkjes is de incidentie van en meer nog de mortaliteit door invasieve cervixcarcinomen zeer drastisch afgeno. men. Desondank is cervixcytologie als methode tot vroegdiagnostiek van fvoorsta. dia van) het cervixcarcinoom niet onomstreden. Een gerandomiseerde interventiestudie naar het effect van cervixcytologie is nooit uitgevoerd en zal wellicht ook niet meer kunnen uitgevoerd worden. Bovendien word een groot aantal vals negatieve en vals positieve resultaten van cervixcyctologie beschreven (zie hoofdstuk 1).

Veel studies hieromtrent zijn echter uitgevoerd zonder dat de afnamekwaliteit van de uitstrijkjes in de analyse betrokken werd.

Het is aannemelijk dat een onvoldoende afnamekwaliteit aanleiding kan geven tot vals negatieve uitstrijkjes en dus tot anvolkomen screeningsresultaten. In het verleden werden reeds een aantal studies uitgevoerd naar het verband tussen de aanwezigheid van endocervicale, respectievelijk plaveiselcellen in het witstrijkje en de kans op een vals negatief resultaat.

Zo werd in verschillende studies en voor verschillende pathologiecriteria aange toond dat de kans op het vinden van pathologische cellen groter is wanneer thet uitstrijkje endocervicale celten bevat (Vooijs 1988, Woodman e.a. 1989). Daarenboven stijgt het relatieve aantal pathologische uitstrijkjes in een tweede uitstrijkje bij patiënten bij wie geen endocervicale cellen gevonden warem in een vorig uitstrijkje (Vooijs 1988) en is er een positief verband tussen de kans op een vals negatief uitstrijkje en de afwezigheid van endocervicale of metaplastische cellen (Woodman 1989). Uiteraard wordt pathologie, zij het in mindere mate, ook gevonden in uitstrijkjes zonder endocervicale cellen en kunnen vals negatieve uitstrijkjes woorkomen ondanks de aanwezigheid van endocervicale cellen (Woodman 1989, Vooilis e.a. $1986 \%$.

Het viel ons overigens op dat in de meeste studies het verband tussen de aanwezigheid van endocervicale cellen en de aanwezigheid wan pathologische cellen berekend werd zonder correctie voor eventuele covariabelen als kenmerken van de patiënt, andere kwaliteitsindicatoren of de inter-observer variatie.

Sinds de allereerste publicaties (Papanicolaou 1941) hebben vele auteurs bena. drukt dat fixatie van een uitstrijkje zo snel mogelijk dient te gebeuren (Buntinx e.a. 1989, Zuna 1984l. Wij vonden echter geen studies waarin de invloed van een late of slechte fixatie op het vinden van pathologische cellen in het witstrijkje onderzocht werd. Wij vonden ook nauwelijks studies waarbij de invloed van andere kwaliteitsindicatoren (celrijkdom, het voorkomen van infectietekens of van celhoopjes) op het voorkomen van pathologische cellen onderzocht werd.

In deze studie hebben wij het verband bestudeerd tussen het al dan niet voldoen aan de vijf in het vorige hoofdstuk beschreven kwaliteitscriteria enerzijds en het aantal, respectievelijk de kans op pathologische uitstrijkjes anderzijds. Naarmate de associatie tussen patholagie en het voldoen aan een kwaliteitscriterium sterker is, 
kan aangenomen worden dat dit criterium een belangrijke voorwaarde beschrijft om eventueel aanwezige pathologie te detecteren en om zo een goede preventie van het cervixcarcinoom te bereiken.

\section{METHODE}

\section{Uitstrijkjes}

17.664 uitstrijkjes werden in dit onderzoek betrokken. Het gaat om alle uitstrijkjes afgenomen door een groep van 238 huisartsen en gynaecologen tijdens een periode vain 11 maanden. Hiertoe behoren zowel screeningsultstrijkjes als uitstrijkjes die op indicatie afgenomen werden. Vier laboranten verrichtten de eerste beoordeling van deze uitstrijkjes. In het kader van een interventiestudie ter verbetering van de afnamekwaliteit, waarover in hoofdstuk 8 en 9 bericht wordt, werd het cytologisch beeld van al deze uitstrijkjes gescoord volgens 5 op voorhand zorgvuldig gedefinieerde kwaliteitscriteria. Daarnaast werden ook de aanwezigheid en het type van pathologische cellen in het uitstrijkje geregistreerd, samen met het geboortejaar van de betrokken patiënte en een code voor de beoordelende laborante.

De criteria woor een beoordeling "goed" zijn dezelfde als vermeld in hoofdstuk 5.

De associatie van elk kwaliteitscriterium met het voorkomen van pathologle werd getoetst met een Chi ${ }^{2}$-toets met Yatescorrectie.

Daarna werd de invloed van de kwaliteitskenmerken op het vinden van pathologische cellen onderzocht met behulp van een stapsgewijze logistische regressie. Daarbij werd tekens gecontroleerd woor het geboortejaar van de patiente en voor de beoordelende laborante. Het zou immers denkbaar zijn dat een bepaalde laborante uitgesproken vaker goed of slecht scoort voor een bepaald kwaliteitskenmerk en tegelijkertijd vaker of minder vaak pathologische cellen herkent. Dit zou dan een belangrijke confounding factor zijn. Ook van de leeftijd wordt een (wisselend) verband met zowel het voorkomen van endocervicale cellen als pathologie in cervixuitstrijkjes beschreven en ook hierdoor zou confounding mogelijk zijn.

De regressie-analyse werd tweemaal uitgevoerd: telkens was het al dan niet voorkomen van pathologische cellen de afhankelijke variabele. Als onafhankelijke variabele gebruikten we naast het geboortejaar van de patiënte ljonger of ouder dan 40 jaer en de identificatie van de screenende laborante eerst het totale kwaliteitsoordeel en daarna de wijf afzonderlijke kwaliteitskenmerken. Er werd voor interactie gecontroleerd door het invoeren van volgende producttermen: (algemeen $k$ waliteitsoordeel $x$ geboortejaarlen (algemeen $\mathrm{kwaliteitsoordeel} x$ laborante) in het eerste regressiemodel. (Voorkomen van endocervicale cellen $x$ geboortejaarl, (voorkomen van endocervicale cellen $x$ laborante), (kwaliteit van de fixatie $x$ geboortejaar) en (kwaliteit van de fixatie $x$ laborante) in het tweede regressiemodel.

Er wordt telkens vanuit een volledig, hiërarchisch opgebouwd model gestart. 
Alle berekeningen werden uitgevoerd met behulp van het BMDP-pakket (BMDP statistical software 1989 ).

\section{RESULTATEN}

\section{Uitstrijkjes}

\subsection{Analyse der ruwe data}

Er waren in deze groep 168 afwijkende uitstrijkjes 19.5 promillel. Er kon geen verband aangetoond worden tussen 4 van de 5 onderzochte kwaliteitskenmerken en een samenvattend algemeen kwaliteitsoordeel enerzijds en het voorkomen van pathologie anderzijds. Bij de kwaliteit van de fixatie werd een significant negatief verband gevonden: een slechte fixatie hangt samen met het vinden van zeven maal meer afwijkende cellen in het uitstrijkje $1 O R=0.151$. Bij nadere analyse is gebleken dat dit niet is toe te schrijven aan één of enkele slecht fixerende artsen.

Tabel 6.1: Aantal (en percentage) pathologische uitstrijkjes met een goede, respectievelijk slechte kwaliteitsbeoordeling per kwaliteitskenmerk (n $=17.6641$

\begin{tabular}{|c|c|c|c|c|}
\hline Criterium & Kwaliteit goed & Kwaliteit slecht & odds ratio & p-wanarde \\
\hline Alg. kwaliteitsoordeel & $143 / 15,47510.91$ & $25 / 2.189(\pi .1)$ & 0.82 & 0,39 \\
\hline Endocervic cellen & $155 / 15.674(1.0)$ & $1311.990(0.71$ & 1.43 & 0.18 \\
\hline Fixatie & $166 / 17.470(09)$ & $12: 194(6.21$ & 0.15 & 0.00 \\
\hline Colrijkdom & $168 / 17.597(1.0)$ & of $67(0)$ & + & 0.86 \\
\hline Cellhoopjes & $158 / 17.630(1.0)$ & or $34(0)$ & 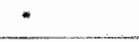 & 1.00 \\
\hline Infectio & $168 / 17.624(1.0)$ & or 40101 & - & 1.00 \\
\hline
\end{tabular}

* niet te barakenar

\section{Logistische regressie}

\subsection{Algemeen kwalliteitsoordeel als onafhankelijke variabele}

Het programma stopte na 1 stap waarbij de productterm (kwaliteitsbeoordeling $x$ geboortejaar) uit de regressievergelijking verwijderd werd. Dit heeft tot gevolg dat de productterm (kwaliteitsbeoordeling $\times$ laborante) behouden blifft, met andere woorden er bestaat een interactie tussen de 4 laborantem enerzijds en het gegeven kwaliteitsoordeel anderzijds. Wij kunnen daarom geen algemene odds-ratio berekenen, wel een afzonderlijke odds-ratio per laborante. U vindt deze in tabel 6.2. Het madel blijkt uitstekend bij de data te passen (Hosmer-Lemeshow, $p=$ 0.8171 . 
Tatbel 6.2: Verband tussen het voorkomen van pathologische cellen en het algemeen kwaliteitsoordeel goed lodds-ratio, gecontroleerd voor de leeftijd, op basis van logistische regiressie)

\begin{tabular}{|c|c|c|c|}
\hline Laborante & Cogtheient. & Odds-ratio & $95 \% \mathrm{~B}(\mathrm{OR})$ \\
\hline 1 & 0.12267 & 1.13 & $0.44-2.88$ \\
\hline 2 & 0.08608 & 1.09 & $0.38 \cdot 3.12$ \\
\hline 3 & 0.43270 & 1.54 & 0.475 .08 \\
\hline 4 & 1.20873 & 0.310 & $0.13-0.68$ \\
\hline
\end{tabular}

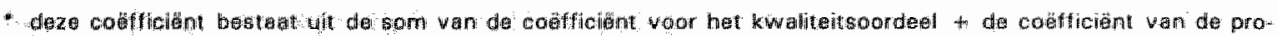
ductarm met de betrokken laboranto.

\subsection{Op basis van vijf afzonderlijke kwaliteitsindicatoren}

Het programma doorliep acht stappen, waarbij achtereenvolgens de volgende termen uit de regressievergeliking verwijderd werden:

- de interactieterm (endocervicale cellen x laborantel

- de aanwezigheid van celhoopjes, tekenen van infectie en celrijkdom

- de interactieterm (fixatie $x$ laborante)

- de identificatie van de screenende laborante

de twee overblijvende interactietermen: (endocervicale cellen $x$ leeftijd) en (fixatie $x$ leeftijd).

De uiteindelijke regressievergelijking omvat, naast de constante, de volgende termen: geboortejaar, aanwezigheid van endocervicale cellen en correctheid van de fixatie. Het model blijkt goed te passen bij onze data. Hosmer-Lemeshow p $=0.556$. Voor de vermelde waarde van de regressiecoëfficiënten had het verwijderen van de laboranten uit de regressievergelijking slechts een geringe invloed.

Tabel 6.3: Verband tussen het voorkomen van pathologische cellen en vijf verschillende kwaliteitskenmerken lodds-ratio, gecontroleerd voor de leeftijd, de screenende laborante en de andere kwaliteitskenmerken op basis van logistische regressie)

\begin{tabular}{|c|c|c|c|c|}
\hline & Coufficion & sice & Odds ratio & $\begin{array}{l}96 \% \text { Bl } 10 \mathrm{dids} \\
\text { ratiol }\end{array}$ \\
\hline Constante & .3 .4431 & 0.4402 & $\vdots$ & $\because$ \\
\hline Geboortejar & 0.47996 & 0.1717 & 162 & $1.15-2.26$ \\
\hline Endocorvicale collen & 0.44446 & 0.3024 & 1.56 & $0.86 \cdot 2.82$ \\
\hline Fixata & -1.9669 & 0.3374 & 0.14 & $0.07-0.27$ \\
\hline
\end{tabular}

Uit deze analyse blijkt dat het geboortejaar louder dan 40 jaar of nietl een belangrijke voorspellende variabele is voor het vinden van pathologie (Odds-ratio = 
1.62), ook na correctie voor de uitstrijkende laborante en voor de vijf kwaliteitsindicatoren.

De aanwezigheid van endocervicale cellen blikt een wrijwel even grote voorspellende waarde te hebben, na correctie voor de leeftijd, voor de screenende laborante en voor de andere kwaliteitsind catoren. De 1 valt echter binnen het $95 \%$ betrouwbaarheidsinterval (ein ook binnen het $90 \%$ betrouwbaarheidsinterval) zodat deze maat niet statistisch significant is bij een alpha van 0.05 (of 0.10 ).

De afwezigheid van een correcte fixatie blijkt een zeer sterke voorspellende variabele te zijn na correctie voor de leeftija van de patiënt, voor de screenende laborante en voor de andere kwaliteitsindicatoren (Odds-ratio $=7.14$ ).

Dit suggereert een sterk verhoogde kans op vals-positieve resultaten bij een slechte fixatie:

De identificatie van de laborante werd erg vroeg door het programma uit het model verwijderd. Dit betekent dat er, althans binnen deze dataset en met dit model, geen significante verschillen tussen de interpretaties van deze vier laborantes aangetroffen werden.

Ook de aanwezigheid van celhoopjes, tekenen van infectie en celrijkdom werden door het programma uit het model verwijderd. Dit betekent dat zij, binnen dezelfde beperkingen, geen significante voorspellende waarde hebben voor het voorkomen van pathologie.

\section{DISCUSSIE}

Een aantal auteurs (Vooijs 1988, Woodman e.a. 1989) beschreef vroeger reeds een verband tussen het voorkomen van endocervicale cellen in een uitstrijkje en de kans op het vinden van pathologische cellen in dat uitstrijkje. Bij de analyse van onze ruwe gegevens konden wij een dergelijk verband niet aantonen. Op basis van logistische regressie vinden wij een relatie tussen het voorkomen van pathologie in uitstrijkjes en de aanwezigheid van endocervicale (en/of metaplastische) cellen (Odds-ratio $=1.56)$. Het $95 \%$ betrouwbaarheidsinterval is echter breed en omvat de $1(95 \% \mathrm{Bl}=0.86-2.82)$. Dit brede betrouwbaarheidsinterval bij een dergelijk hoog aantal uitstrijkjes hangt samen met het lage percentage afwijkende uitstrijkjes dat bij screeningsonderzoeken gebruikelijk is.

De bevinding dat het aantal uitstrijkjes met pathologische cellen zevenmaal hoger is bij een slechte fixatie, ook na correctie voor de onderzochte confounders, is opmerkelijk. Dit suggereert dat een slechte fixatie aanleiding is tot een groot aantal vals-positieve uitstrijkjes. Het is bekend dat uitstrijkjes snel aan de lucht drogen. Wanneer dat gebeurt treden cellulaire artefakten op, de kleuring wordt onvoldoende intens en afwijkende cellen kunnen gemaskeerd worden (Holm e.a. 1988, Zuma 1984). Het is bovendien denkbaar dat de optredende artefakten pathologie niet alleen kunnen maskeren, maar ook imiteren. Mogelijk kan dit een deel van de valspositieve uitslagen bij cervixcytologie verklaren.

$\mathrm{Na}$ correctie voor de onderzochte variabelen vonden wij geen significante invloed van de celrijkdom, van het voorkomen van ontstekingscellen of van het voorkomen van celhoopjes op het vinden van pathologie. Er moet in dit verband gewezen worden op het relatief klein aantal uitstrijkjes met een onvoldoende resultaat voor deze drie kwaliteitskenmerken. 
Uit een onderzoek van Spurrett e.a. (Spurrett e.a. 1989) en uit eigen onderzoek (zie deel 3 van dit proefschrift) zijn inmiddels argumenten naar voren gekomen voor cle stelling dat de afwezigheid van plaveiselcellen in een cervixuitstrijkje ook aanleiding kan geven tot vals negatieve uitstrijkjes. In een volgend onderzoek zullen wij deze factor bij onze analyse betrekken.

Uiteraard betekent het vinden van afwijkende cellen bij cytologisch onderzoek nog niet dat er pathologie aanwezig is en omgekeerd. Het cervixuitstrijkje blijft een onderzoek met screeningsdoeleinden en kan nooit aanleiding zijn tot definitieve diagnostische uitspraken.

Dit onderzoek suggereert een verband tussen een aantal kwaliteitskenmerken en de kans op een afwijkend resultaat. Ook bij perfecte kwaliteit zullen er om allerlei redenen echter nog steeds vals negatieve resultaten zijn. Zo betekent het vinden van zowel endocervicale cellen als plaveiselcellen dat de overgangszone met grote waarschijnlijkheid bij thet uitstrijken geraakt is. Dit betekent echter niet dat deze zone ook volledig uitgestreken werd. Hoe kleiner een tumor is, hoe groter de kans dat deze gemist wordt. Er bestaat op dit ogenblik, voor zover wij weten, geen zekere methode om hierop te toetsen.

Samenvattend : Hoewell niet statistisch significant wijzen de resultaten van deze studie in dezelfde richting als voorgaande studies, namelijk dat de afwezigheid van endocervicale cellen aanleiding geeft tot een verminderde kans op het vinden van pathologische cellen. Dit verhoogt de kans op vals negatieve uitstrijkjes. Voorts zijn er sterke aanwijzingen dat een late of onvoldoende fixatie aanleiding kan geven tot het voorkomen van vals positieve uitstrijkjes. Deze bevindingen vormen een belangrijke stimulans voor het geven van zorgvuldige aandacht aan de afnamekwaliteit bij cervixuitstrijkjes. Zoals ook elders beschreven werden relatief meer pathologische uitstrijkjes gevonden bij vrouwen die ouder dan 40 jaar zijn, dan bij jongere vrouwen. De interobserver variatie tussen de vier betrokken laboranten was verwaarloosbaar als confounder bij thet nagaan van de invloed van de afzonderlijke kwaliteitskenmerken op het voorkomen van pathologische cellen. 
HOOFDSTUK 7

\section{INTER-OBSERVER VARIATIE BIJ HET BEOORDELEN VAN DE AFNAMEKWALITEIT VAN CERVIXUITSTRIJKJES}

Via dit onderzoek werd gepoogd inzicht te verkrijgen in de mate van interobserver variatie bij het beoordelen van de afnamekwaliteit wan cervixuitstrijkjes.

De vier laboratoriumassistenten, die binnen het Centraal Laboratorium te Antwerpen verantwoordelijk zijn voor de screening van cytologische preparaten, scoorden elk voor 71 dezelfde witstrijkjes het voorkomen van endocervicale cellen, de $k$ waliteit van de fixatie, de celrijkdom en het voorkomen van celhoopjes.

De niet voor toeval gecorrigeerde inter-observer overeenkomst tussen paren beoordelaars varieerde tussen $58-80 \%$ voor het woorkomen van endocervicale cellen en tussen 86-100\% voor de andere kwaliteitskenmerken. De groepskappa's, een maat voor de interobserver overeenkomst, bovenop de overeenkomst door toeval, gaf een behoorlijk resultaat voor de aanwezigheid van endocervicale cellen 10.32-0.54 na dichotomisatiel. Voor de andere $k$ waliteitscriteria bleek de kappa om technische redenen vaak niet te berekenen.

De inhoud van dit hoofdstuk is een bewerking van:

* Buntinx F., Schouten H.J.A. Knottnerus J.A., Crebolder H.F.J.M., Essed G.G.M. Interobserver variation in the assessment of the sampling quality of cervical smears. Ter publicatie aangeboden. 


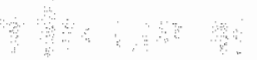

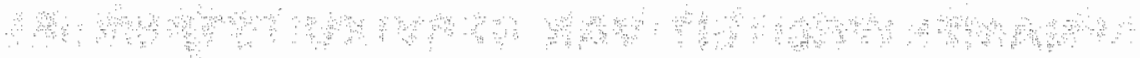

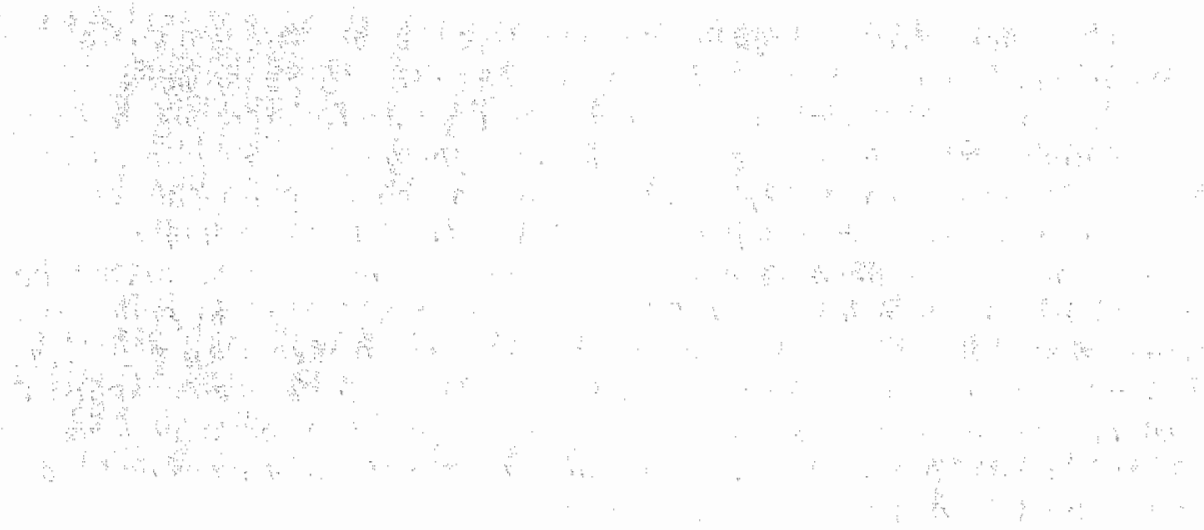




\section{INLEIDING}

Bil het beoordelen van cervixuitstrijkjes wordt sinds gerume tijd aandacht besteed aan de inter-observer variatie. Verschillende auteurs beschreven reeds een wisselende, meestal vrij belangrijke variatie bij het beoordelen van cytologische afwijkingen in het uitstrijkje (Glenthoj e.a. 1986, Hicklin e.a. 1984, Husain e.a. 1984, Kern e.a. 1977, Klinkhamer e.a. 1989, Naujoks e.a. 1990, Shulman e.a. 1975, Willocx e.a. 1987). Recent verscheen in het Journal of Clinical Epidemiology een studie over de variatie bij het beoordelen van histologische afwilkingen in biopten (De Vet e.a. 1990). Wij vonden echter slechts één studie die de mate van inter-en intra-observer overeenstemming onderzoekt bij het beoordelen van kwaliteitscriteria (Klinkhamer e.a. 1989). De door deze auteurs onderzochte criteria zijn de aanwezigheid van plaveiselcellen en van endocervicale of metaplastische cellen.

De kwaliteit van een uitstrijkje wordt bepaald door de afnamekwaliteit en door de bewerkingen die in het laboratorium gebeuren. Wij beperken ons in deze bijarage tot de afnamekwaliteit. De afnamekwaliteit van een uitstrijkje kan beoordeeld worden op basis van het microscopisch beeld. Elders in dit proefschrift werd het begrip afnamekwaliteit geoperationaliseerd door middel van in totaal 6 criteria: aanwezigheid van storende tekenen van inflammatie, aanwezigheid van plaveiselcellen, aanwezigheid van endocervicale (en/of metaplastischel cellen, celrijkdom, kwaliteit van de fixatie en hinderlijke aanwezigheid van celhoopjes. De vier laatste van deze zes criteria worden ook in dit onderzoek betrokken.

In dit onderzoek werd daarom de mate van inter-observer overeenkomst onderzocht tussen vier ervaren cytologische laboranten bij het beoordelen vam vier kwaliteitscriteria voor dezelfde reeks preparaten. Wij waren daarbij zowel geinteresseerd in de ruwe percentages overeenkomst als in de voor toeval gecorrigeerde mate van overeenkomst.

\section{METHODE}

Deze studie werd uitgevoerd binnen de afdeling Cytologie van het Centraal Laboratorium te Antwerpen, één van de grotere cytologische diensten in Vlaain. deren. Er worden jaarlijks ongeveer 25000 uitstrijkjes verwerkt door vier laboranten. Daarbij zijn zowel screeningsuitstrijkjes als uitstrijkjes dile op indicatie gemaakt werden. Abnormale of verdachte uitstrijkjes worden routinegewijs herbeoordeeld door de hoofdlaborante en, in laatste instantie, door én van de pathologen. De uitstrijkjes zijn afkomstig van zowel huisartsen als gynaecologen.

Voor deze studie beoordeelden de vier betrokken laboranten, onafhankelijk van elkaar, elk dezelfde 71 uitstrijkjes die op ến dag ingestuurd werden. Zij scoorden voor elk uitstrijkje op een driepuntsschaal de aanwezigheio van endocervicale (en/of metaplastische) cellen, de celrijkdom, de kwaliteit van de fixatie en de aanwezigheid van celhoopjes. De score was dusianig dat score 1 stond voor slechte kwaliteit en score 3 voor goede kwaliteit.

De gebruikte criteria voor een beoordeling "goed" waren dezelfde als in hoofdstuk 5 beschreven. 
De betrokken laboranten waren ervan op de hoogte dat hun beoordelingen in het kader van een onderzoek geanalyseerd zouden worden. Er was tussen hen echter geen overleg over deze uitstrijkjes en er werden ook geen bijzondere afspraken gemaakt.

De frequenties waarin deze laboranten voor elk van de vier kwaliteitskenmerken een bepaalde score toekenden, worden onderling vergeleken en de scores van alle laboranten worden paarsgewijze onderling vergeleken.

Daarna wordt de inter-observer overeenkomst bepaald met behulp van Cohen's kappa (Cohen 1960). De kappa is een maat voor de overeenkomst in de beoordeling tussen twee of meer observatoren, in aanvulling op de overeenkomst die alleen door toeval reeds te verwachten zou zijn. De kappa's worden gerapporteerd uitgaande van de oorspronkelike registratiegegevens op basis van een driepuntsschaal voor elk kwaliteitscriterium. Zij worden daarna opnieuw berekend na dichotomisatie van de gegevens (afnamekwaliteit is al dan niet voldoende voor dit criteriumly Het is deze laatste waarde die wellicht de belangrijkste consequenties heeft, omdat de aframekwaliteit van een uitstrijkje op basis hiervan als voldoende of onvoldoende beschouwd wordt.

De kappa bevindt zich steeds tussen -1 en +1 , waarbif nul staat voor een mate van overeenkomst tussen de observatoren die niet groter is dan wat op basis van toeval te verwachten zou zijn. De waarde plus én staat voor een volledige overeenkomst tussen de observatoren.

Omdat wij in deze studie te maken hebben met meer dan twee observatoren, hebben wij ook gebruilk gemaakt van een groepskappa. (Schouten 1986). Deze geeft een maat voor de gemiddelde overeenkomst tussen alle paren observatoren, bovenop de gemiddelde overeenkomst die tussen deze paren op basis van toeval te verwachten is.

Groepskappass worden gerapporteerd, samen met hun $95 \%$ betrouwbaarheids Interval.

\section{RESULTATEN}

Per kwaliteitscriterium waren tussen nul (celrijkdom) en negen beoordelingen niet beschikbaar. Van de 284 beoordelingen die per criterium maximaal mogelijk zijn, zijn er dus 275 tot 284 beschikbaar voor analyse.

Tabel 7.1 toont de frequentie waarmee de vier laboranten elk van de drie mogelijke scores aan de vitstrijkjes toevezen. Opvallend daarbij is dat voor de drie laatste kenmerken de score slecht niet en de score matig zelden toegekend werd.

De niet voor toeval gecorrigeerde mate van overeenkomst tussen paren beoordelaars (tabel 7.2 ) varieert tussen $86-100 \%$ woor celrijkdom, tussen $89.94 \%$ voor de kwaliteit van de fixatie, tussen $86-99 \%$ voor de aanwezigheid van storende celhoopjes en wussen $58-80 \%$ voor de aanwezigheid van endocervicale cellen. 
Tabel 7. 1: Frekwentie van toekennen van de verschillende kwaliteitsscores door de 4 laboranten (\%)

\begin{tabular}{|c|c|c|c|c|c|c|c|c|c|c|c|c|}
\hline \multirow{2}{*}{$\begin{array}{l}\text { Labo } \\
\text { rant }\end{array}$} & \multicolumn{3}{|c|}{ Celtijigdom } & \multicolumn{3}{|c|}{ Fixatie } & \multicolumn{3}{|c|}{ Cehoopios } & \multicolumn{3}{|c|}{ Endoontricale nellem } \\
\hline & 1 & 2 & 3 & 1 & 2 & 3 & q & 2 & 3 & 1 & 2 & 3 \\
\hline A & 0 & 6 & 94 & 0 & (6) & 94 & 0 & 2 & 98 & 36 & 19 & 4.6 \\
\hline $\mathrm{B}$ & 0 & 14 & 86. & 0 & 11 & 29 & 0 & 14 & 86 & 35 & 25 & 39 \\
\hline c & 0 & 0 & 100 & 0 & 0 & 100 & 0 & 0 & 100 & 37 & 0 & 63 \\
\hline D & 0 & 0 & 100 & 0 & 6 & 94 & 0 & 1 & 98 & 37 & 0 & 63 \\
\hline
\end{tabular}

$1=$ slecth:

2 matig

$3=$ goed

Tabel 7.2: Percentagle ruwe, niet voor toeval gecorrigeerde overeenkomst tussen paren beoordelaars

\begin{tabular}{|c|c|c|c|c|}
\hline \multirow[t]{2}{*}{ Laboranten paar } & \multicolumn{4}{|c|}{ Kwaliteiltscriteriun } \\
\hline & $\begin{array}{c}\text { Endocervicale } \\
\text { cellen }\end{array}$ & Celhoopies & Fixatie & Cellijikdom \\
\hline$\quad 1-2$ & $\therefore \quad 64$ & 89 & 96 & 89 \\
\hline $1-3$ & 68 & 98 & 94 & 94 \\
\hline $1-4$ & 74 & 97 & 94 & 94 \\
\hline $2-3$ & 58 & 80 & 89 & 86 \\
\hline $2-4$ & $\therefore 62$ & 87 & $\mathrm{BS}$ & 86 \\
\hline $3 \cdot 4$ & 80 & 99 & 94 & 100 \\
\hline
\end{tabular}

In tabel 7.3 werden de voor toeval gecorrigeerde inter-observer overeenkomsten voor alle paren van beoordelaars samengevat. In de rechter bovenhelft (boven de diagonaal] van elk van de vier deeltabellen staat voor elk paar de gewone kappa. waarde, links onder de overeenkomstige waarde na dichotomisatie van de beoordelingen.

Voor de laatste drie criteria zijn veel kappa's nul of niet te berekenen. Dit volgt uit het feit dat een aantal mogelijke (slechte) beoordelingen door geen enkele beoordelaar toegekend werden, zodat ook in de cellen van de $3 \times 3$ tabel waaruit de kappa berekend werd, een groot aantal nullen verschijnen. Wanneer tenminste één van de laboranten slechts één van de mogelijke scores toekent, zal de resulterende kappa voor dit paar en voor dit criterium steeds nul ziljn. Wanneer er tussen twee beoordelaars een perfecte overeenkomst bestaat die inhoudt dat beider voor alle beoordeelde uitstrijkjes slechts eenzelfde score gebruilkten, zal de op basis van 
toeval verwachte overeenstemming tussen deze beoordelaars 100\% zijn. De mogelijke extra overeenkomst wordt dan nul en de kappa is niet te berekenen.

Tabel 7.3: Kappa's voor overeenkomst in de beoordeling door paren laboranten. Boven de diagonalen de gewone kappa's. Onder links de kappa's na dichotomisatie van de beoordelingen

\begin{tabular}{|c|c|c|c|c|c|c|c|c|c|c|c|c|c|c|c|c|}
\hline \multirow[t]{2}{*}{ Labonant } & \multicolumn{4}{|c|}{ Endorervicale cellen } & \multicolumn{4}{|c|}{ Celhooples: } & \multicolumn{4}{|c|}{ Fixwatis } & \multicolumn{4}{|c|}{ Celrijkdom } \\
\hline & A & $E$ & $c$ & $\mathrm{D}$ & A & $B$ & $c$ & $D$ & A & $B$ & $c$ & $D$ & A & $\mathbb{B}$ & $c$ & $\mathbb{D}$ \\
\hline A & n & .44 & 45 & .615 & 8 & 20 & 0 & .02 & b & 70 & 0 & 47 & 1 & 38 & 0 & 0 \\
\hline$B$ & 46 & 5 & $\begin{array}{r}32 \\
\end{array}$ & 30 & .20 & 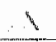 & 0 & $\$ 6$ & .70 & h & 0 & .28 & .38 & 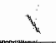 & 0 & 0 \\
\hline c & .69 & 42 & 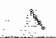 & 58 & 0 & 0 & $y$ & 0 & 0 & 0 & $\checkmark$ & 0 & 0 & 0 & $b$ & 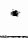 \\
\hline D & .84 & 48 & 88 & 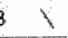 & .02 & .16 & 0 & $>$ & .47 & .28 & 0 & $>$ & 0 & 0 & - & $V$ \\
\hline
\end{tabular}

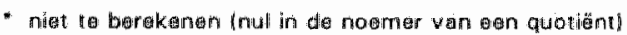

Dit alles heeft tot gevolg dat de gegevens over de aanwezigheid van endocervicale cellen voor ons doel het best interpreteerbaar zijn. Zoals te verwachten zijn de kappa's na dichotomisatie (0.42-0.84) duidelijk hoger dan de kappa"s voor drie klassen $(0.32-0.55)$.

In tabel 7.4 is weergegeven in welke mate er overeenstemming is in de beoordelingen voor elke door een willekeurige laborante toegekende score. De tabel laat zich als valgt lezen: als een willekeurige laborante aan uitstrijkje $x$ een bepaalde score toekent, hoeveel kans is er dan dat een willekeurige andere laborante uit. deze groep tot elk van de drie mogelijke scores komt? Bijvoorbeeld: als een laborante een bepaald uitstrijkje voor de aanwezigheid van endocervicale cellen als slecht beoordeelt, is er gemiddeld $70 \%$ kans dat een willekeurige andere laborante uit deze groep dit uitstrijkje ook als slecht beoordeelt. Er is gemiddeld $11 \% \mathrm{kans}$ op een score matig en $19 \%$ op een score goed.

Voor vitstrijkjes met een beoordeling slecht (dit betekent dat geen endocervicale cellen aangetroffen werden is er dus nog $19 \%$ kans dat tenminste én van de andere laboranten een beoordeling goed aflevert (dit betekent dat er een ruime hoeveelheid endocervicale cellen aangetroffen werd). Het omgekeerde gebeurt in $13 \%$ van de gevallen. Het bijkt voorts dat er over de score matig, toegekend door een laborante, bij collega"s minder overeenstemming bestaat dan over de meer extreme beoordelingen goed en slecht. In tabel 7.4 vindt $U$ ook de resultaten van de berekeningen van de groepskappa's. Zij variëren van minimaal voor de drie laatste criteria tot 0.45 en 0.56 voor de aanwezigheid van endocervicalle cellen. 
Tabel 7.4: Frekwentie van de verschillende beoordelingen door telkens drie laboranten ten opzichte van de beoordeling van de vierde laborant. In totaal waren er per kwaliteitskenmerk maximaal 284 beoordelingen mogelïk.

\begin{tabular}{|c|c|c|c|}
\hline $\begin{array}{l}\text { ENDOCERVICALE } \\
\text { CELLEN }\end{array}$ & Stecht $(\%)$ & Matig $(\%)$ & Goed $(\%)$ \\
\hline slectr: & 70 & 11 & 19 \\
\hline matig & $\begin{array}{r}36 \\
\end{array}$ & 9 & 55 \\
\hline goed & 13 & 11 & 75 \\
\hline 8 & $\begin{array}{l}\text { groepskappa : } \\
\text { na dichotamisatie : }\end{array}$ & $\begin{array}{l}0.4510 .39-0.51) \\
0.5610 .48-0.83)\end{array}$ & $\therefore$ \\
\hline CELHOOPJES & Stgent $1 \%$ ) & Matig $(\%)$ & Goed ( $\%)$ \\
\hline slecht & 0 & 0 & 0 \\
\hline matig: & 0 & $\therefore$ & 100 \\
\hline \multirow[t]{2}{*}{ good } & 0 & 4 & 96 \\
\hline & \multicolumn{2}{|c|}{$\begin{array}{ll}\text { groepskappa: } & 0.08(0.0 .16) \\
\text { na dichotomisatie: } & 0.08(0.0 .16)\end{array}$} & \\
\hline FIXATIE & Slecht $(\%)$ & Matig $1 \%$ & Veal $1 \%$ \\
\hline slecht & 0 & 0 & 0 \\
\hline matig : & $\therefore 0$ & $=\quad 33$ & 67 \\
\hline veel & $\because$ & 4 & 96 \\
\hline & $\begin{array}{l}\text { groepsikappa: } \\
\text { ma dichotomisatia: }\end{array}$ & $\begin{array}{l}0.29(0.04-0.54) \\
0.2910 .04-0.54) \\
\end{array}$ & \\
\hline CELRLJKDOM & Slecht $1 \%$ & Matig $(\%)$ & Veal $1 \%$ \\
\hline slecht & 0 & 0 & $a$ \\
\hline matig. & 0 & 20 & 80 \\
\hline veel & 9 & 4 & 96 \\
\hline : & $\begin{array}{l}\text { groupskappa: } \\
\text { ne dichotomisetie: }\end{array}$ & $\begin{array}{l}0.12(0 \cdot 0.24) \\
0.12(0 \cdot 0.241\end{array}$ & \\
\hline
\end{tabular}

Bij elke kappa-waarde staat het $95 \%$ betrouwbaarheidsinterval tussen haakjes.

\section{DISCUSSIE}

Cohen"s kappa is een maat voor de inter-observer overeenkomst, die oorspronkelijk ontwikkeld werd voor twee observatoren en voor twee of meer klassen per waar. nemingsmethode (Cohen 1960). Voor situaties waarin er meer dan twee klassen per waarnemingsmethode zijn, werd later zowel een gewone als een gewogen kappa ontwikkeld (Cohen 1968). In deze studie hebben wij ervoor gekozen om. 
naast de gewone kappa's, ook kappa's te berekenen nadat de data gedichotomiseerd werden. Daarbij werd uitgegaan van de redenering dat het vooral van belang is of de afnamekwaliteit van een uitstrijkje al dan niet als voldoende beschouwd wordt voor een correct cytologisch onderzoek.

Hierbil dient benadrukt dat de kappa geen maat is voor de overeenkomst tussen beoordelaars, maar een maat voor de voor toeval gecorrigeerde overeenkomst tussen beoordelaars.

Voor drie van de vier onderzochte kwaliteitscriteria vinden wij een geringe spreiding van de toegekende beoordelingen, waarbij wooral het lage aantal slechte beoordelingen opvalt. Deze gegevens komen overeen met de resultaten van een beschrijvend onderzoek bij ruim 4000 opeenvolgende uitstrijkjes uit hetzelfde laboratorium. waarover wij in hoofdstuk 5 van dit proefschrift rapporteren. Het aantal uitstrijkjes met onvoldoende fixatie lag daarbij rond $2 \%$, terwij het aantal uitstrijkjes met storende celhoopjes of met onvoldoende celrijkdom rum beneden de $1 \%$ bleef.

De kappa"s, en met name de groepskappa's, voor de aanwezigheid van celhoopjes, voor de kwaliteit van de fixatie en voor de celrijkdom, liggen erg laag, zelfs met $95 \%$ betrouwbaarheids-intervallen waar de nul in begrepen is, Vergelijking met de niet gecorrigeende percentages interobserver overeenkomst leert ons dat kappawaarden in deze speciale situatie wellicht niet de beste manier zijn om inzicht te krijgen in de mate wan interobserver overeenkomst. De wel erg speciale verdeling van de beoordelingen heeft mamelijk een grate invloed op de kappa-waarden (Knottnerus 1990).

Meer illustratief voor de clinicus zijn wellicht de gegevens in tabel 7.4. Deze illustreert welke verschillen er optreden tussen beoordelaars voor de verschillende mogelijke beoordelingen.

Anders ligt het voor de aanwezigheid van endocervicale cellen. De meer evenwich tige spreiding van de beoordelingen over de mogelijke scores heeft een lagere ongecorrigeerde interobserver overeenkomst tot gevolg, terwijl de kappa's hoger zijn. Wij krijgen hier een ongewogen groepskappa van 0.45 . Na dichotomisatie wordt bit 0.56 . Beide wayrden vallen in de categorie die beschouwd wordt als een behoorlijk resultaat (Fleiss 1981). De indeling van Fleiss wordt vrij algemeen gebruikt. $\mathrm{Zij}$ is daarom echter niet minder arbitrair. Voor veel clinici is het wellicht relevanter te vermelden dat een dergelijk resultaat van dezelfde grootte-orde is als bijwoorbeeld gevonden werd voor de detectie van een voelbare pols ter hoogte van de A. dorsalis pedis of voor de aanwezigheid van een relevante ST-T verandering bij een inspannings ECG (Sackett e. a. 1985). Ook de overeenkomst in de beoordeling van de mate van pathologie in cervixbiopsieèn door 4 pathologen resulteerde in een (gewogen) kappa van 0.56 (De Vet e.a. 1990). Voor de beschrijving van pathologie bij het cytologisch onderzoek van cervixuitstrijkjes zijn ons geen kappaberekeningen bekend. De belangrijke inter-observer verschillen zijn ook op dit gebied echter uitvoerig beschreven /Glenthoj e.a. 1986, Hicklin e.a. 1984, Husain e.a. 1984, Kern e.a. 1977, Klinkhamer e.a. 1988, Naujoks e.a. 1990, Shulman e.a. 1975, Willocx e.a. 1987).

De belangrijkste bron van verschillen in de beoordeling van de aanwezigheid van endocervicale cellen lijkt te liggen in de toekenning van score "matig": Een 
dergelijke beoordeling wordt door een collega gemiddeld slechts in $9 \%$ van de gevallen bevestigd. Wellicht is deze categorie ook voor de betrokken laboranten minder duidelijk gedefinieerd en ook de consequenties van dergelijke score zijn minder duidelijk. Dit is mogelijk ook de reden waarom deze score niet vaak ten door twee laboranten in ons onderzoek zelfs niet) gebruikt wordt.

Als een beoordeling mede afhankelijk is van een subjectieve inschatting izoals het geval is bij microscopisch onderzoek) is het belangrijk dat er tussencategorieën bestaan waarin men de minder duidelijke gevallen kan indelen. De bevinding dat de categorie weinig gebruikt wordt lijkt ons voor deze score dan ook belangrijker dan de preciese inter-observer overeenkomst.

Elders in dit proefschrift worden verschillende factoren beschreven die een rol spelen bij het maken van uitstrijkjes van goede kwaliteit. De inter-observer verschillen die bij het beoordelen hiervan vastgesteld werden, moeten eens te meer voorzichtig stemmen bij het formuleren van conclusies en bij thet interpreteren van onze bevindingen.

Daarnaast vormen onze resultaten voor de cytologische laboratoria een uitdaging om, via een proces van standaardisering en interne feed-back, ook bij de beoordeling van kwaliteitscriteria de intra-en inter-observer variabiliteit terug te dringen, zowel binnen de laboratoria als tussen de laboratoria. Lopend onderzoek moet aantonen wat daarbij de rol kan zijn van geautomatiseerde analysemethoden. 


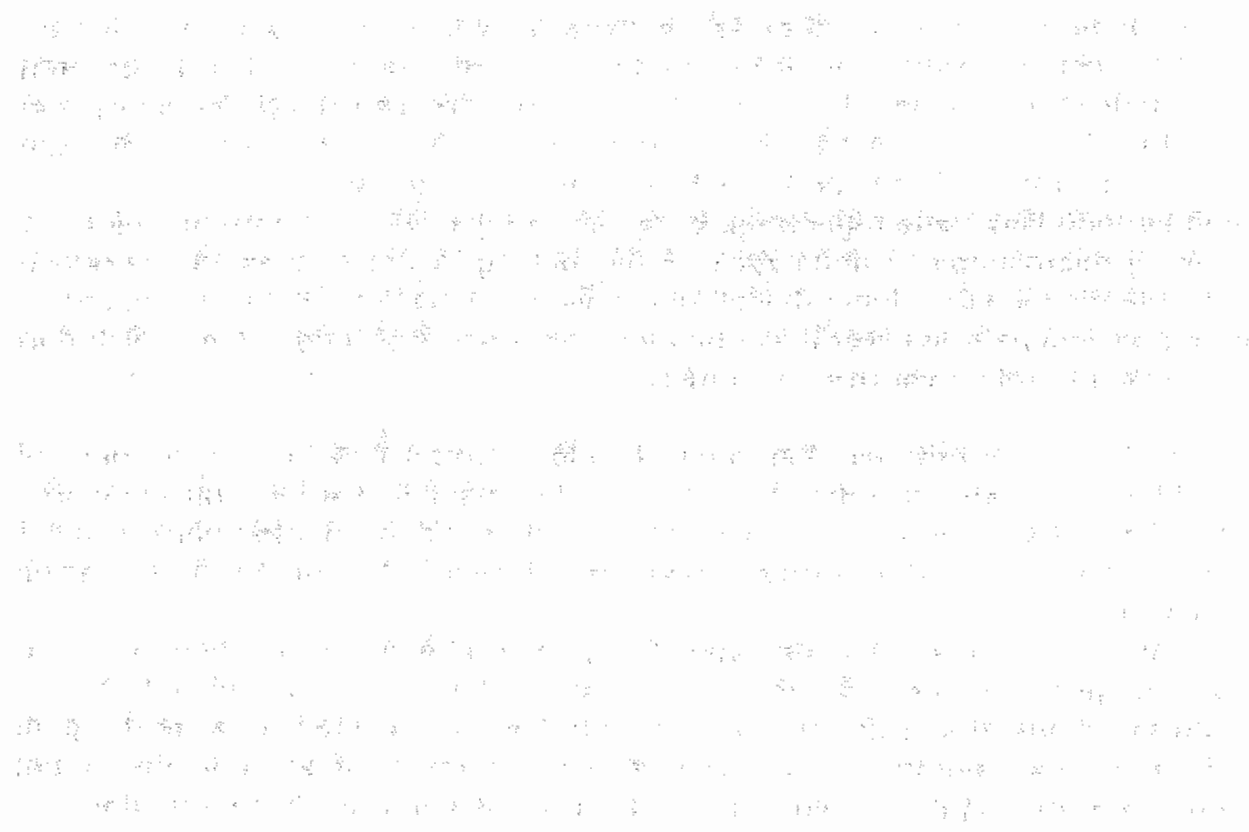




\section{HOOFDSTUK 8}

\section{INVLOED VAN VERSCHILLENDE VORMEN VAN FEED-BACK OP DE AFNAMEKWALITEIT VAN CERVIXUITSTRIJKJES}

Een gecontroleerde en gerandomiseerde interventiestudie

Via een gecontroleerde en gerandomiseerde interventiestudie werd het effect nagegaan van drie, in intensiteit toenemende, methoden van reed-back op de afnamekwaliteit van cervixuitstrijkjes.

Voor het geheel van alle artsen werd een systematisch, doch niet significant toenemend effect gevonden op het percentage uitstrijkjes met afwijkende cellen per arts. Regressieanalyse toonde een significante daling van het veranderingsquotiënt voor afwezigheid van endocervicale cellen in de twee groepen, warin gebruik gemaakt werd van maandelijkse kwaliteitsoverzichten en vergelijking met de resultaten van de andere artsen, tot $75 \%$ van de waarden in de twee andere groepen. Voor de artsen die tijdens de onderzoeksperiode meer dan 50 uitstrijkjes instuurden, is er een duidelijke toename van het gemiddelde percentage witstrijkjes met endocervicale cellen en van het gemiddelde percentage uitstrijkjes met een algemeen kwaliteitsoordeel "goed" per arts bij toenemende intensiteit van de interventie. Er was geen effect op de andere $k$ waliteitsindicatoren.

Voor het geheel van alle tijdens de onderzoeksperiode vervaardigde uitstrijkjes werd een halvering gevonden van het percentage uitstrijkjes zonder endocerwicale cellen en wan het percentage uitstrijkjes met een algemeen kwaliteitsoordeel slecht in de twee interventiegroepen waarin gebruik gemaakt werd van maandelijkse $k$ waliteitsoverzichten en vergeliking met de resultaten van de andere artsen.

De inhoud van dit hoofdstuk is een bewerking van;

* Buntinx F., Knottnerus J.A., Crebolder H.F.J.M., Essed G.G.M., Schouten H., Seegers T. Does feedback improve the quality of cervical smears? Ter publicatie aangeboden. 


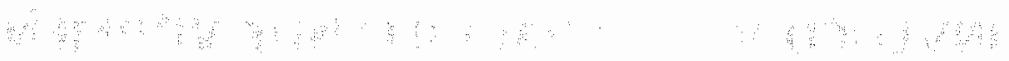

Q 


\section{INLEIDING}

Verschillende werkwijzen zijn in het verleden gebruikt om de vaardigheden en het gedrag van artsen bij de afname van cervixuitstrijkjes te verbeteren. Het formuleren van goede richtlijnen, protocollen of standaarden (Buntinx e.a. 1989, Anoniem 1989. Baker 1989) is daarbij een belangrijke eerste stap. De implementatie daarvan is echter niet zo eenvoudig.

Als wij een verbetering van de afnamekwaliteit wensen, betekent dit dat er gewerkt moet worden aan een gedragsverandering bij de betrokken uitstrijk(st)ers. Voor gedragsverandering is informatie wel noodzakelijk, maair niet voldoende. Op het geblied van de cervixcytologie wordt daarbij veel verwacht van feed back naar de uitstrijk(st)ers over de afnamekwaliteit van de door hen ingestuurde uitstrijkjes. Boon e.a. beschrijven in dit verband een stijging van het percentage endocervicalen-positieve uitstrijkjes van $70 \%$ naar $84 \%$ in de loop van een jaar, nadat hum laboratorium de resultaten van iedere arts registreerde en opvallend slecht preste* rende artsen telefonisch instrueerde (Boon e.a. 1986). Daarenboven vonden deze auteurs een opmerkelijke afname van de spreiding vain deze resultaten tussen de artsen. Baker adviseert het mededelen van individuele resultaten aan te vullen met geregelde overzichten, die de arts in staat stellen zijn eigen resultaten te vergelijken met die van zijn collega's (Baker 1989).

In verschillende centra is het inmiddels gebruikelijk om bij ieder uitstrijkje de afnamekwaliteit te evalueren of om tenminste het al dan niet aanwezig zijn van endocervicale cellen op het uitslagformulier te vermelden:

Behalve de reeds vermelde publicatie van Boon e.a., werd in de literatuur echter geen evaluatie van het effect van vormen van feed-back op dit terrein gevonden (zie in dit verband het literatuuroverzicht in hoofdstuk 1 van dit proefschrift). In ons onderzoek worden feed-backmethoden van toenemende intensiteit via een interventie-onderzoek op hun effectiviteit beoordeeld en onderling vergeleken.

Daarbij besteden wij zowel aandacht aan de invloed van de onderzochte interventies op de uitstrijkkwaliteit van de betrokken artsen (vam belang om het effect van een vergelijkbare interventie in andere artsengroepen te kunnen voorspellen) als aan de invloed op het totaal van alle onderzochte vitstrijkjes. Dit is van belang omdat dit ons informatie geeft over het netto effect van onze interventie op de volledige patiëntengroep en op deze wijze extra beleidsrelevantie biedt.

Uit vroeger onderzoek (zie vooral hoofdstuk 5) blijkt dat het presteren vain artsen volgens sommige kwaliteitscriteria een verband vertoont met de discipline en het geslacht van de uitstrijkende arts, met het aantal uitstrijkjes dat jaarlijks gemaakt wordt en met de gebruikte afnametechniek. Het is helemaal niet zeker dat deze factoren ook een rol spelen bij de mate waarin artsen reageren op kwaliteitsverbe terende initiatieven. Omdat hierover geen onderzoeksresultaten voorhanden zijn, is het alleszins de moeite waard deze factoren via subgroep-analyse in ons onder. zoek te betrekken.

De vraagstelling voor dit onderzoek werd als volgt geformuleerd: In welke mate wordt de kwaliteit van cervixuitstrijkjes, gemaakt tijdens routine consultaties, beinvloed door verschillende vormen van feed-back? Wordt daarbij ook de inter-dokter variatie beïnvloed? 
In welke mate worden deze resultaten beinvloed door de discipline en het geslacht van de arts, de gebruikte afnametechniek en het aantal door de arts geproduceerde uitstrifkjes?

\section{METHODE}

\section{Setting}

Voor deze studie kwamen de uitstrijkjes in aanmerking van alle Nederlandstalige artsen die in loop van 1988 tenminste 20 uitstrijkjes voor cytologisch onderzoek aanboden aan de dienst Anatomopathologie van het Centraal Laboratorium in Antwerpen (n $=183$ ).

De selectie op basis van de taal geschiedde om praktische redenen. De selectie op basis van een minimum aantal uitstrijkjes werd ingebouwd om het mogelijk te maken een eventuele evolutie in de afnamekwaliteit te kunnen vaststellen.

Deze uitstrijkjes zijn routinegewijs gemaakt in het kader van de dagelijkse praktijkvoering van huisartsen en gynaecologen. Dit betekent dat er zowel screeningsuitstrijkjes toe bethoren als uitstrijkjes afgenomen wegens klachten.

Voor elke arts werden de volgende gegevens verzameld: geslacht, discipline (huisarts of gynaecoloog), universiteit en jaar van afstuderen, provincie waar zij werkzaam zijn en het aantal uitstrijkjes, gemaakt tijdens het voorgaande jaar (1988). Alle artsen werden daarenboven bij het begin van het onderzoek telefo. nisch ondervraagd over het door hen gebruikte materiaal voor het afnemen van een uitstrijkje. Dit werd geclassificeerd in volgende vijf groepen: Cytobrush, al dan niet in combinatie met een spatel, spatel alleen (één of twee afnames met een Ayretype spatel of met een scherpe-tip spatel), twee spatelafnames met de twee uiteinden van een gecombineerde spatel en een restgroep.

Met ingang van 1 juni 1989 werd van ieder aangeboden uitstrujkje door de dienst Anatomopathologie van het Centraal Laboratorium te Antwerpen een gedetailleerde kwaliteitsbeoordeling gemaakt. Daarbij werd op een driepuntsschaal een algemeen kwaliteitsoordeel gegever, alsmede een specifieke beoordeling van respectievelijk de celrijkdom van het preparaat, het voorkomen van slecht beoordeelbare celhoopjes, het aantal endocervicale (em/of metaplastische) cellen, de kwaliteit van de fixatie en het voorkomen van inflammatiesverschijnselen.

De volgende criteria werden gebrulkt voor de beoordeling 'goed":

- Endocervicalle cellen: aanwezig of squameuze metaplasie aanwezig.

- Fixatie: goed resultaat, beoordeeld volgens de aftekening van de celstructuren, de kleurbaarheid en de netheid van het preparaat.

Celrijkdom: voldoende epitheelcellen aanwezig.

- Celhoopjes: niet of slechts sporadisch voorkomen van een slecht beoordeelbaar celgroepje.

- Infectietekens: geen inflammatietekens aanwezig in dergelijke mate dat de beoordeling van het preparaat erdoor bemoeilijkt wordt.

De algemene kwaliteitsbeoordeling was goed als er endocervicale of metaplastische cellen aanwezig zijin en als de andere items tenminste met 2 gescoord 
worden op een driepuntsschaal. Een uitstrijkje werd als afwijkend beschouwd als er tenminste geringe dysplasie gevonden werd (Pap $\geq$ IIIa).

Per maand werden per arts voor leder kwaliteitskenmerk de percentages berekend van alle beoordeelde uitstrijkjes die voor het betrokken kwaliteitskenmerk de beoordeling goed kregen. Deze percentages, samen met het aantal en het percentage pathologische uitstrijkjes, werden in onze analyse betrokken.

\section{Inter-observer variatie}

De beoordeling van alle uitstrijkjes gebeurde door vier ervaren laboranten.

De toewijzing van de uitstrijkjes aan de laboranten werd door toeval bepaald.

Voor het begin van deze studie beoordeelden deze vier laboranten, onafhankelijk van elkaar, elk 71 uitstrijkjes die op ëen dag ingestuurd werden. Zij scoorden op een driepuntsschaal de aanwezigheid van endocervicale cellen, de kwaliteit van de fixatie, de celrijkdom en thet voorkomen vari slecht beoordeelbare celhoopjes.

Hun resultaten werden onderling vergeleken. $U$ vindt een verslag hiervan in hoofdstuk 7. Samengevat vonden wij tussen $58-80 \%$ overeenkomst tussen paren observatoren voor de beoordeling van de aanwezigheid van endocervicale cellen en tussen $86-100 \%$ voor de andere kwaliteitscriteria. Als maat voor de voor toeval gecorrigeerde overeenkomst tussen paren observatoren vonden wij groepskappa's tussen 0.08 (celhoopjes) en 0.56 (endocervicalle cellen).

De betrokken laboranten waren op de hoogte van de interventiestudie maar zij wisten niet bij welke onderzoeksgroep iedere arts ingedeeld was.

\section{Bepalen van de basislijn}

Gedurende een eerste periode van drie maanden werd van ieder preparaat een interne kwaliteitsbeoordeling geregistreerd. Voor de uitstrijkende arts veranderde er in deze periode niets. Zoals in de voorgaande maanden en jaren, ontving hij van leder uitstrijkje de gebruikelijke uitslag met de beschrijving van het beeld en de PAP-klasse. De gegevens uit deze periode werden gebruikt voor het vastleggen van een basislijn, waarmee de resultaten wit de interventieperiode tijdens de analyse vergeleken werden.

\section{Basisinformatie}

Na het starten van de interventies was er een inloopperiode van 2 maanden. Alle artsen ontvingen bij het begin van deze periode een overdruk van een fotoreportage over de correcte afnametechniek van een cervixuitstrijkje met verschillende mogelijke afname-instrumenten. (Buntinx e.a. 1989)

Vanaf het begin van deze periode werden de extra vermeldingen op de uitslag ingevoerd. Tevens werden de eerste maandrapporten samengesteld en verzonden. De registratiegegevens uit deze periode werden alleen voor de controlegroep ver. werkt (effect van de fotoreportage via een voor - na-vergelijking). Deze periode diende om de interventies op te starten en op kruissmelheid te laten komen. Zij vervulde daardoor een rol die een bijkomende toepassing is van wat door Knip. schild, Leffers en Feinstein beschreven is als "Qualification Period" en door Lang als "Run-in" (Knipschild e.a. in press). 


\section{Interventie}

Na de inloopperiode werd er, athankelijk van de groep waarbij de uitstrijkende arts ingedeeld werd, een continue interventie verricht door middel van feed-back. De effectieve interventieperiode duurde 6 maanden.

GROEP A:

Voor de artsen uit deze groep veranderde er verder niets. Zij kregen zoals steeds voor ieder uitstrijkje de gebruikelijke uitslag.

Deze groep diende als controlegroep.

GROEP B:

Op basis van de bevindingen bif de interne kwaliteitsbeoordeling, werd aan iedere uitslag een extra zin toegevoegd: "De technische kwaliteit van dit uitstrijkje was ultstekend, matig, onvoldoende". Bij een onvoldoeinde beoordeling, werd hieraan toegevoegd : "omwille van..." Deze zin kan bijvoorbeeld als volgt worden afgemaakt: "onvoldoende endocervicale cellen" of "te veel bloedbijmenging".

GROEP C:

Idem als B. Daarenboven werd maandelijks aan iedere arts een overzicht toegestuurd van de kwaliteitsbeoordelingen over de voorbije maland, uitgezet tegen het gemiddelde van alle ontvangen utstrijkjes.

GROEP D:"

Idem als C. Daarenboven ontvingen deze artsen, wanneer daartoe aanleiding bestond, gerichte voorlichting, waarbij de vastgestelde tekorten vertaald werden in adviezen voor hun technisch handelem en verwijzing naar gerichte nascholingsvormen.

Als aanleiding werd beschouwd: tenminste $5 \%$ uitstrijkjes met een onvoldoende resultaat voor het betrokken kwaliteitskenmerk tijdens de geëvalueerde maand. Een voorbeeld van de verschillende rondgestuurde formulieren is in dit proefschrift apgenomen als bijlage 1 .

De uitgevoerde interventies in de verschillende groepen worden grafisch weergegeven in figuur 8.1 .

Fig. 8.1: Vormen van feed-back gebruikt in de vier interventiegroepen

\begin{tabular}{|c|c|c|c|c|}
\hline \multirow[t]{2}{*}{ Intarwentio } & \multicolumn{4}{|c|}{ Interverintegroep } \\
\hline & A. & $B$ & $\mathrm{C}$ & 10 \\
\hline Extrazir bil alk protocol & & $\quad x x$ & $x$ & $\quad x$ \\
\hline Maandolijks overzicht der resultaten & & & $x \times$ & $x$ \\
\hline Vargelaking mo per group & & & $x \times$ & $=x \times$ \\
\hline Graricht advies & & : & $\therefore<$ & $x x=$ \\
\hline
\end{tabular}




\section{Randomisatie}

Alle artsen werden bij het begin van de inloopperiode at random ingededin $6 e n$ van vier groepen. De randomisatie gebeurde gestratificeerd (Pocock, 1983 ) naar de discipline (huisarts of gynaecoloogl, naar het aantal ingestuurde unsthy 1988 en naar de gebruikelijke afnametechniek, op basis van door de computer gegenereerde toevalsgetallen.

Vier artsen, werden na de randomisatie uit de onderzoeksgroep verwijderd, twee uit de controlegroep en telkens één uit groep $C$ en D. Eén arts bleek op de hoogte van het onderzoek, één arts kreeg toch feed-back, terwill hij bij de controlegroep ingedeeld was en twee artsen stuurden tijdens de onderzoeksperiode geen enkel uitstrijkje in. De analyse heeft dus uiteindelijk betrekking op 179 artsen.

De randomisatie werd gecontroleerd door vergelijking van de vier groepen op basis van het aantal, de discipline en het geslacht der uitstrijkende artsen, de provincie waar zij werken en het gebruikte afnamemateriaal (indeling in 5 groepen). Hierop werd getoetst door middel van een chi ${ }^{2}$-test. Ook de gemiddelde leeftijd van de patiënten en het totaal aantal in 1988 ingestuurde uitstrijkjes per groep werden vergeleken.

\section{Ethische aspecten}

De uitstrijkende artsen waren tijdens de registratieperiode niet van deze studie op de hoogte. Indien dit wel het geval zou geweest zijn, zou zulks wellicht een belangrijke vertekening van de resultaten tot gevolg gehad hebben. Het onderzoeksdesign was zodanig dat het onmogelijk was op enige wijze schade te berokkenen aan de betrokken artsen of hun patiënten. De interventies gebeurden open en bloot zodat de betrokken artsen daar op ieder ogenblik wel van op de hoogte waren. Hermee werd een advies van de Medisch-Ethische Commissie van het Vlaams Huisartsen Instituut gevolgd, die zich in deze zin uitsprak.

Na het afsluiten van de registratieperiode werden alle betrokken artsen van het onderzoek op de hoogte gebracht en werd hun mening gevraagd over de feed-back die zij ontvingen. De resultaten hiervan worden in hoofdstuk 9 gepubliceerd. Deze waren vrïjwel unaniem positief van aard.

\section{Sample size berekening}

Om een verbetering van minimaal $5 \%$ in het gemiddelde percentage slechte uitstrijkjes per arts te kunnen vaststellen ten opzichte van de non-interventiegroep, uitgaande van een alfa-fout van 0.05 en een beta-fout van 0.05 , en een SD van $4 \%$, zouden volgens op voorhand uitgevoerde berekeningen per groep 20 artsen nodig zijn. Dit aantal werd ruimschoots gehaald voor het geheel van de interventiegroepen en voor een deel van de subgroepen.

\section{Analyse}

De geregistreerde kwaliteitsbeoordelingen per uitstrijkje en per arts werden per interventiegroep en per periode verzameld. Als afzonderlijke perioden worden beschouwd:

- de basislijnperiode van drie maanden (juni tot augustus 1989).

- de inloopperiode van twee maanden (september en oktober 1989).

- de interventieperiode van zes maanden (november 1989 tot april 1990). De interventie was tijdens deze periode volledig operationeel. 
De analyse werd verricht per kwaliteitskenmerk. Voor elke groep werd het gemiddelde berekend van de percentages uitstrijkjes van slechte kwaliteit per arts in een onderzoeksperiode. Dit was de basis voor de verdere analyses.

Aangezien wij hier te maken hebben met clusters van resultaten per arts (er kan immers aangenomen worden dat de werkwijze van een arts steeds min of meer vergelijkbaar is), en aangezien zowel de randomisatie als de interventies op het niveau van de onderscheiden artsen plaatswonden, zou een analyse alleen op basis van het totale aantal uitstrijkjes per groep onjuist zijn. Dit werd herhaaldelijk gesteld en in een methodologisch review artikel nogmaals benadrukt door Donner e.a. (Donner e.a. 1987, Donner e.a. 1989). Op deze wijze werd tevens gecontroleerd voor een eventuele overmatige invloed van één of enkele artsen met een groot aantal uitstrijkjes. Wel werden de belangrijkste resultaten van de analyse op basis van de percentages uitstrijkjes van slechte kwaliteit, gemaakt tijdens een bepaalde onderzoeksperiode door alle artsen van een onderzoeksgroep, tevens ter informatie vermeld. De vergelijkingen van deze resultaten werden niet statistisch getoetst. Zij voldeden immers niet aan de vereiste onafhankelijkheid van waarneming.

Voor twee artsen zijn de artsgegevens onvolledig, zodat de meeste analyses uitgevoerd zijn op 177 artsen.

\section{Analyse van de ruwe gegevens}

Vergelijkingen werden gemaakt tussen de verschillende groepen en binnen elke groep tussen de verschillende periodes. Dit werd gedaan voor elk kwaliteitskenmerk afzonderlijk, voor de algemene kwaliteitsbeoordeling en voor het voorkomen van pathologische cellen.

Voor elke arts afzonderlijk werd het verschil berekend tussen het percentage uitstrijkjes van onvoldoende kwaliteit tijdens de interventieperiode en tijdens de basislijnperiode (interventieverschil), samen met een quotiënt van deze beide percentages. Naar dit quotiënt, dat conceptueel volledig vergelijkbaar is met een relatief risico (relative risk, rate ratio), wordt in deze tekst verwezen als het veranderingsquotiēnt.

Een veranderingsquotiënt kleiner dan 1 of een interventieverschil kleiner dan nul betekenen een vermindering in het percentage uitstrijkjes van onvoldoende kwaliteit voor een criterium.

Voor ledere groep werden hiervan gemiddelden berekend, telkens met een (nonparametrisch berekend) $95 \%$ betrouwbaarheidsinterval. Deze gemiddelden werden gebruikt voor de vergeliking tussen de groepen.

De interventieverschillen en de veranderingsquotiënten van de interventiegroepen werden vergeleken met die van de controlegroep. Aangezien er niet kan worden uitgegaan van een normale verdeling van de resultaten wordt daarbij gebruik gemaakt van niet-parametrische testen (Mann-Whitney en Kruskall-Wallis).

Teneinde zicht te krijgen op het bestaan van een lineaire trend voor een effectmaat in relatie tot de toenemende intensiteit van de interventie, werd tevens een Spearman Rank correlatie coefficiënt berekend voor de relatie tussen de intensiteit van de interventie en het veranderingsquotiënt, respektievelijk het verschil (Armitage e.a. 1987). Een $p<0.05$ wordt beschouwd als een argument voor het bestaan van een trend. 
In iedere groep is er een aantal artsen dat bij het bepalen van de basislin (tijdens de eerste 3 maanden van de registratie) voor een bepaalde kwaliteitsindicator een goed resultaat haalde voor alle uitstrijkjes. Voor deze artsen is een verbetering dus niet meer mogelijk en is feed-back ook minder relevant. Het is voor deze artsen ook niet mogelijk een veranderingsquotient te berekenen op basis van het aantal "slechte" uitstrijkjes. Immers dit quotiênt $=n / 0$, waarbij n overeenkomt met het percentage uitstrijkjes met een beoordeling onvoldoende tijdens de interventieperiodel. Daarom werden al deze berekeningen uitgevoerd op basis van de resultaten van die artsen die tijdens de basislijnregistratie voor het betrokken kenmerk tenminste 1 uitstrijkje met de beoordeling onvoldoende hebben voor het aantal afwijkende uitstrijkjes wordt dits tenminste 1 afwijkend uitstrijkje).

Het effect van de fotoreportage op de gemiddelde maandresultaten kan slechts in de controlegroep geïsoleerd bestudeerd worden door middel van een voor - navergelijking. In de drie interventiegroepen begint rond dezelfde tijd immers ook het vermelden van een $k$ waliteitsoordeel op het uitslagformulier.

\section{Subgroepanalyse}

De analyse op basis van de gegevens per arts werd herhaald voor elke discipline, voor elk geslacht van de uitstrijkende arts en voor elke categorie van het gebruikte afnamemateriaal (voor de afwezigheid van endocervicale cellen en voor het algemeen kwaliteitsoordeel) en voor 3 categorieën van het aantal uitstrijkjes dat tijdens de interventieperiode gemaakt werd.

\section{Regressieanalyse}

Voor het voorkomen van endocervicale cellen, het meest relevante kwaliteitskenmerk, analyseerden wij het effect van de interventies, gecontroleerd voor een groot aantal covariabelen, met behulp van stapsgewijze multiple lineaire regressie. Een zelfde analyse voor de andere kwaliteitsindicatoren bleek niet uitvoerbaar gezien het lage aantal data dat nog beschikbaar was na de vereiste logistische transformatie (log van nul is miet te berekenen).

Afhankelijke variabele was het natuurlijk logaritme van het veranderingsquotiënt voor het percentage uitstrijkjes zonder endocervicalle cellen per arts. Onafhankelijke variabelen waren de interventiegroep (met behulp van drie dummy -variabelen), het. percentage uitstrijkjes zonder endocervicale cellen in de basislijnperiode, de gebruikte afnametechniek (met behulp van vier dummy-variabelen), het geslach: en de discipline van de uitstrijkende arts en het totaal aantal uitstrijkjes ingestuurd tijdens de interventieperiode. De dummy-variabelen voor de interventiegroep en voor de afnamemethode werden daarbij elk als één set in de regressievergelijking opgenomen of eruit verwijderd.

Er werd vertrokken van een leeg model. De vereiste p-waarde voor opmame of verwijdering van een variabele was 0.05 .

Daarna analyseerden wij op dezelfde wijze de invloed van elke nieuw toegevoegde interventietechniek. Daarbij dienden de interventiegroepen waarbij de betrokken techniek niet gebruikt werd als controlegroep. Zo berekendem wil het effect van een extra zinnetje op het uitslagformulier (groep $B+C+D$ versus groep $A$ ), van de maandelijkse overzichten (groep $C+D$ versus groep $A+B$ ) en van de gerichte 
adviezen (groep D versus groep $A+B+C$ ). Hierbili werd voor dezelfde covariabelen gecontroleerd als in de eerste regressieanalyse.

\section{Spreiding tussen de artsen}

Als maat voor de spreiding van de resultaten tussen de verschillende artsen van een groep werden twee waarden gebruikt. Voor elke groep en voor elke periode werden een gemiddelde en de vilfentwintigste en vijfenzeventigste percentiel berekend van de percentages uitstrijkjes van slechte kwaliteit per arts. Daarenboven werd een variatiecoéfficient berekend die overeenkomt met de deling van de standaard deviatie door het gemiddelde voor de betrokken waarde.

In navolging van Armitage werd er getoetst op een afname van de spreiding door het berekenen van een Spearmann Rank correlatiecoefficiënt tussen $\times 1$ en $Y 1$ waarbili $X 1=$ de som van de twee waarden (interventieperiode en basislijnperiode) voor ledere individuele arts uit een groep en $Y 1$ - het verschil van deze waarden (Armitage e.a. 1987, p158).

Er wordt aangenomen dat de spreiding afgenomen is bij het vinden van een significante correlatie.

\section{Invloed van het aantal ingestuurde uitstrijkjes}

De invloed van het aantal ingestuurde uitstrijkjes op een eventuele verbetering per groep werd voor de afwezigheid van endocervicale cellen en voor het algemeen kwaliteitsoordeel nagegaan. Daarvoor werd een Spearmann Rank correlatie coefficiënt berekend tussen het totaal aantal tijdens de interventieperiode ingestuurde uitstrijkjes per arts enerzijds en de veranderingsquotiënt, respectievelijk het interventieverschil voor het betrokken kwaliteitskenmerk anderzijds.

\section{Gebruikte programmatuur}

Alle statistische berekeningen, behalve de sample size berekening, gebeurden met behulp van het BMDP-programma (BMPD-statistical Software 1989). Voor de sample size berekening werd gebruik gemaakt van het programma Epistat (Gustavson 1985).

\section{RESULTATEN}

\section{Controle van de randomisatie}

De randomisatie werd gecontroleerd na het verwijderen van de vier uitvallende artsen (tabel 8,1 ).

Er werd geen statistisch significant verschil $\left(\mathrm{chi}^{2}\right)$ aangetoond tussen de artsen uit de vier groepen in geslacht, discipline, provincie en gebruikte afnametechniek. De verdeling van de uitstrijkjes over de 4 laboranten die het cytologisch onderzoek verrichtten lijkt vrij thomogeen. De patiënten uit de vier groepen zijn gemiddeld ongeveer even oud. 
Tabel 8.1: Kenmerken van artsen en uitstrijkjes in de vier interventiegroepen. Tussen haakjes de percentages. De p-waarden slaan op een chi $^{2}$-test

\begin{tabular}{|c|c|c|c|c|c|}
\hline INTERVENTIEGROEP & $A$ & $\mathrm{~B}$ & $c$ & $D$ & $p$ \\
\hline \multicolumn{6}{|l|}{ ARTSEN } \\
\hline Totad antal & 46 & $\therefore 46$ & 43 & 44 & \\
\hline Huisartsien & $42 \cdot 1911$ & 401871 & $41(95)$ & 411931 & \\
\hline Gynaiecologen & 419 & 6. (1) & $2(5)$ & $3(7)$ & .53 \\
\hline Man & 361781 & $36: 1781$ & $34(79)$ & $33(75)$ & \\
\hline Wrouns & $10(22)$ & $\quad 10(22)$ & $9(21)$ & 111251 & .97 \\
\hline Sparel in of 21 & $13(29)$ & $15133)$ & $18(42)$ & $17(40)$ & \\
\hline Cytolorush $1+1$. Spatell & $26(58)$ & $25(56)$ & $23(5.3)$ & $22(51)$ & \\
\hline Anclere & $6(13)$ & $5 \| 11$ & $2|5|$ & 419 & .77 \\
\hline Prov. Limburg: & $21(46)$ & 211461 & $20(47)$ & 261591 & \\
\hline Prov. Antwerpen & $2146\}$ & $20(43)$ & $21(49)$ & $14(32)$ & \\
\hline Andere Provinaies & $4(9)$ & $5(11)$ & $2(5)$ & $4(9)$ & .68 \\
\hline \multicolumn{6}{|l|}{ UITSTRUUKJES } \\
\hline Aantalfarts * & 104 & 128 & 87 & 74 & \\
\hline Aantal/huisarts & 59 & 71 & 65 & 57 & \\
\hline Totaal arantal & 4. 805 & $5: 86: 3$ & 3.725 & 3.272 & \\
\hline Leeftijd * $( \pm$ SD $)$ & $411 \pm 121$ & $39( \pm 12)$ & $38( \pm 13)$ & $391 \pm 131$ & \\
\hline Laborante A & $1.400(29)$ & $1.770(30)$ & $1.028(28)$ & $960 \backslash 29$ & \\
\hline Laborante B & $1.358(28)$ & $1.666(28)$ & $1,089(29)$ & $906128)$ & \\
\hline Laborante $C$ & $941(20)$ & $1.097(19)$ & $813(22)$ & 6561201 & \\
\hline Laborante D & $1.106\{23\}$ & $1.330(23)$ & $795(21)$ & $750(23)$ & \\
\hline
\end{tabular}

- Gemiddalda per graep

\section{Onvoldoende celrijkdom, storende tekens van infectie of celhoopjes}

Het aantal uitstrijkjes met onvoldoende kwaliteit op éên van deze drie kwaliteitskenmerken bedraagt tijdens de basislijnperiode in iedere onderzoeksgroep ruim minder dan $1 \%$ (tabel 8.2).

$E r$ is dus eigenlijk geen duidelijke verbetering meer mogelijk en de invloed van de interventies op deze indicatoren wordt niet verder geanalyseerd. Dit ligt anders voor de afwezigheid vam endocervicale cellen, voor de kwaliteit van de fixatie en voor het algemeen kwaliteitsoordeel. 
Tabel 8.2 Percentage uitstrijkjes met onvoldoende kwaliteit, als percentage van het totaal aantall uitstrijkjes in een groep, per kwaliteitsindicator tijdens de basislijinperiode (alle artsen)

\begin{tabular}{|c|c|c|c|c|}
\hline \multirow{2}{*}{ MWDICATOR } & \multicolumn{4}{|c|}{ MTERVENTIEGROEP } \\
\hline & $A$ & $B$ & c & $\mathrm{D}$ \\
\hline Endocervicalle cellem & $\because 13.5$ & 16.7 & 120 & 17.1 \\
\hline Finatio & 1.8 & 2.3 & 12 & 1.9 \\
\hline Celrikdom & $0 . \pi$ & 0.6 & 0.6 & 0.8 \\
\hline Inf puctio & 0.1 & 0.2 & 0.2 & 0.0 \\
\hline Cellhoopjes & 0.0 & 0.2 & 0.2 & 0.3 \\
\hline Algemeen kw aliteits-oordeel & 16.0 & 18.0 & 13.2 & 18.8 \\
\hline
\end{tabular}

\section{Invloed van de fotoreportage (voor-na vergelijking)}

Bij het vergelijken van de maandresultaten voor de controlegroep in $=4805$ uitstrijkjes) valt op dat in de maanden oktober en november een duidelijke daling optreedt wan het percentage uitstrijkjes zonder endocervicale cellen, met een onvoldoende fixatie en met een algemeen kwaliteitsoordeel slecht, terwijl er ter zelfder tijd een piek gevonden wordt in het percentage afwijkende vitstrijkjes. (fig. 8.2).

\section{Andere kwaliteitscriteria - Ruwe data}

De resultaten worden samengevat in tabel 8.3 .

Bif het analyseren van de gemiddelde resultaten per arts wordt geen systematische invloed van onze interventies vastgesteld op de afwezigheid van endocervicale cellen, een slechte fixatie of een onvoldoende resultaat bij het algemeen kwalliteitsoordeel. Behalve een enkele uitzondering (multiple comparisons effect?) is de Mann-Whitney voor geen der interventiegroepen en voor geen enkele kwaliteitsindicator significant.

Er is in alle groepen een stijging in het percentage afwijkende uitstrijkjes, dat systematisch toeneemt bif het intensiever worden van de interventie. In alle groepen bevindt nul zich echter binnen het $95 \%$ betrouwbaarheidsinterval voor het interventieverschil (voor-na vergelijking), zodat hier niet kan gesproken worden van een statistisch significante verbetering, althans niet bij een significantieniveau van 0.05 . Ook de Mann-Whitney test (vergelijking van de verschillende interven. tiegroepen met de controlegroepl geeft niet-significante $p$-waarden. De correlatiecoëfficiënten zijn telkens erg dicht bij nul en niet significant zodat niet van een duidelijke correlatie tussen de intensiteit van de interventie en de toename van de verbetering gesproken kan worden. 
Fig. 8.2: Verloop in de tijd van het percentage uitstrijkjes van slechte kwaliteit voor de verschillende kwaliteitsindicatoren en van het percentage afwijkende uitstrijkjes (maandresultaten voor de controlegroep)

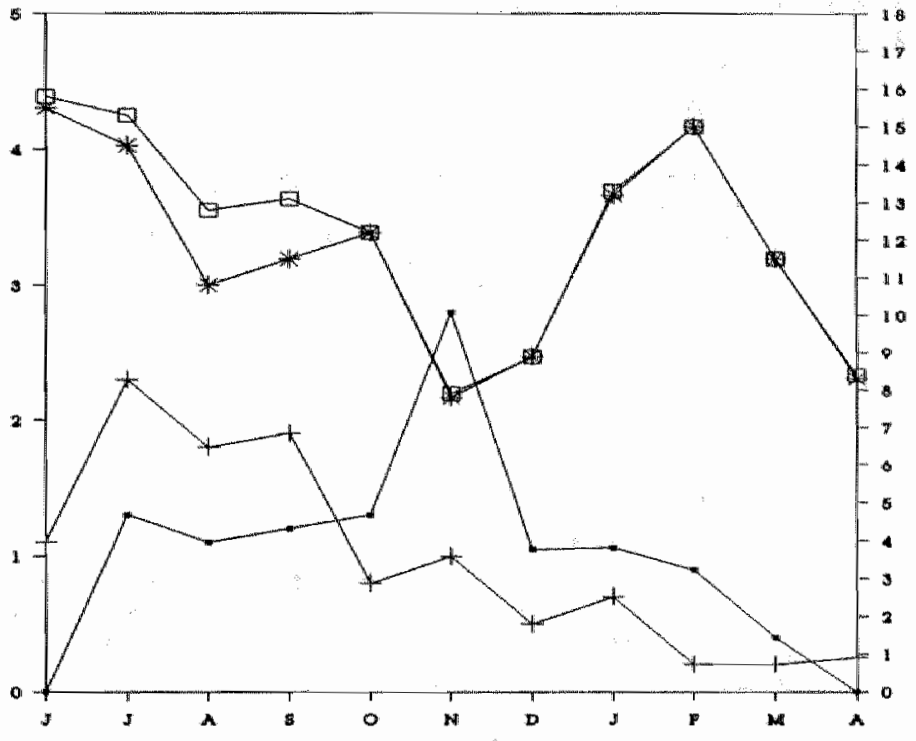

1 : percentage af wijkende uirstrijkjes

+ : percentage uitstrijkjes met onwoldoende tixatie

* : percentage uitstrikjes zonder endocerwicale cellen

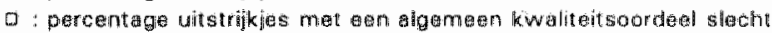

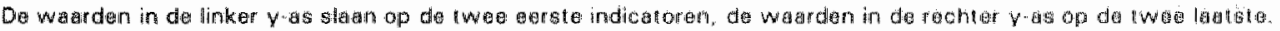


Tabel 8.3: Gemiddelden per groep van de percentages kwalitatief slechte, respectievelijk afwijkende uitstrijkjes per arts voor de verschillende kwaliteitsindicatoren ( $n=177$ artsen). Tussen haakjes staat het $95 \%$ betrouwbaarheidsinterval.

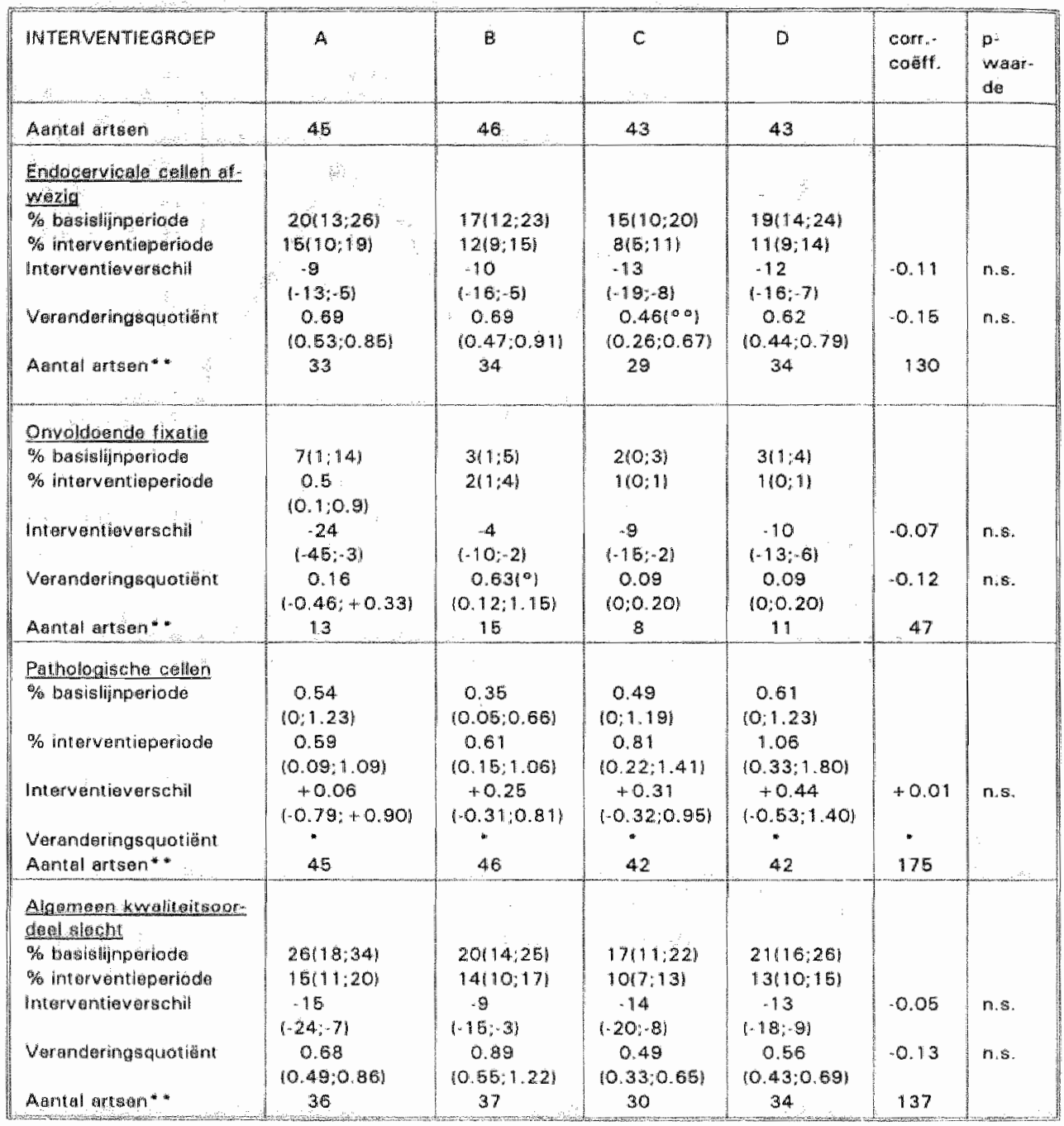

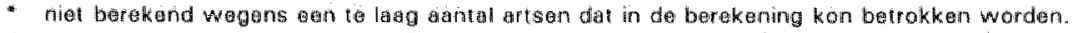

* akntall artsen dal hn anmerking kwam voor de berekening van het veranderingsquotiant.

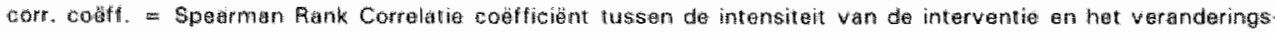

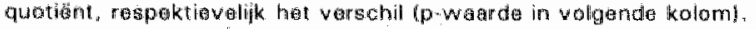

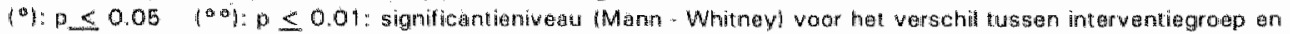
controlegroep. 


\section{Subgroepanalyse en regressieanalyse}

\section{Afwezigheid wan endocervicale cellen}

De gegevens voor de verschillende subgroepen zijn op het eerste gezicht nogal verwarrend (tabel 8.4). Wij zien een systematische daling in het aantal uitstrijkjes zonder endocervicale cellen per arts bij de vrouwelijke artsen, bij de gynaecologen, bij de artsen die bij thet begin van het onderzoek aangaven de gecombinearde spatel + Cytobrushafnametechniek te gebruiken en bij artsen die tijdens de interventieperiode meer dan 50 uitstrijkjes insturen. In deze groepen is de Kruskall. Wallis toets voor de veranderingsquotiënten significant bij de spatel + Cytobrush artsen ( $p=0.03$ ) en bij de artsen met meer dan 50 uitstrijkjes ( $p=0.03)$. De MannWhitney testen zijn woor geen enkele subgroep consistent significant. De correlatie tussen veranderingsquotiënt en toenemende interventie is significant voor de gynaecologen, voor de spatel + Cytobrush-artsen en voor de artsen met meer dan 50 uitstrijkjes.

Voor de interventieverschillen vinden wij vrijwel een zelfde patroon als voor het veranderingsquotiënt.

Fig. 8.3: Gemiddlelde per groep (A, B, C, D) van de percentages uitstrijkjes zonder endocervicale enlof metaplastische cellen per arts in beide periodes (I = basislijnperiode, $\|=$ interventieperiode)

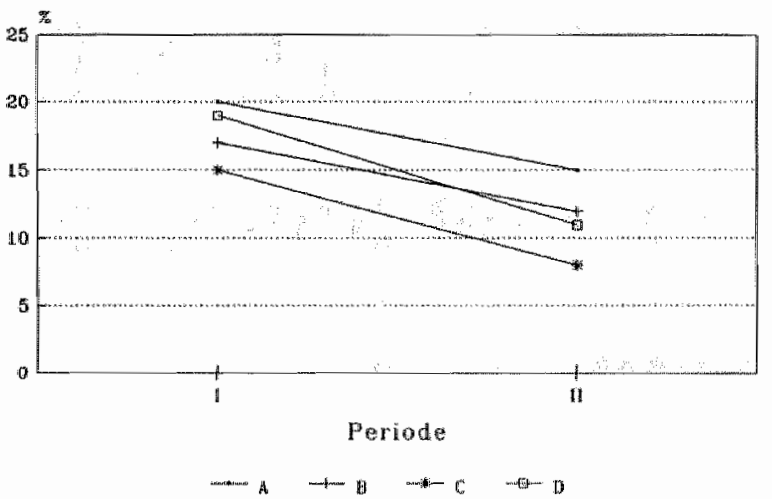

\section{Regressie analyse}

De uitgevoerde regressieanalyse toont een deels significante invloed van de interventiegroep op het veranderingsquotiënt. De odds ratio"s voor het veranderingsquotiënt van de interventiegroepen ten opzichte van de controlegroep (met hun $95 \%$ BII zijn:

voor groep B: $0.90(0.64-1.07)$

voor groep C: $0.60(0.42-0.87)$

voor groep D: $0.80(0.57-1.14)$

De grootste Cook afstand bedraagt 0.06 , wat wijst op afwezigheid van uitschieters. 


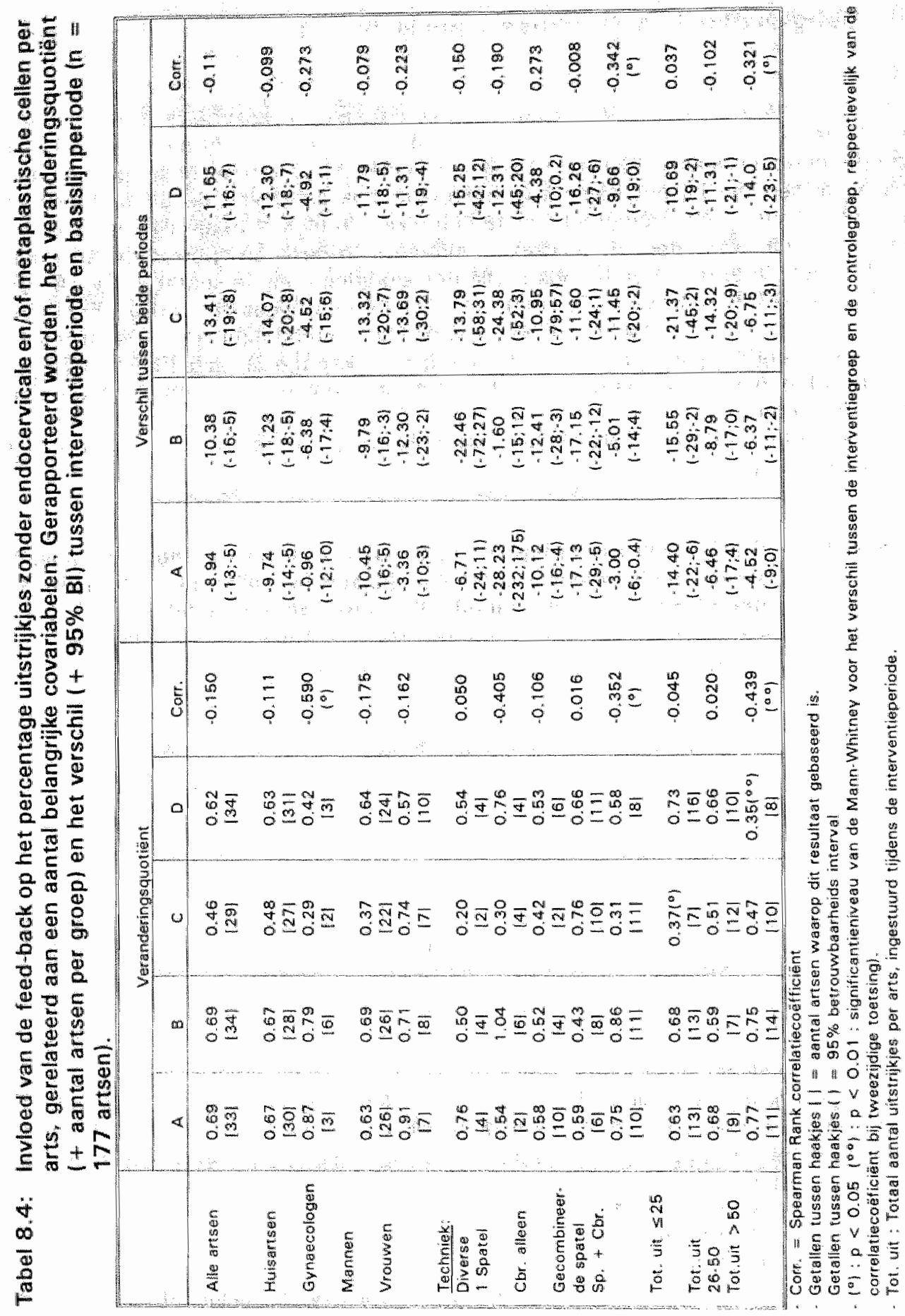


Er wordt geen significant resultaat gevonden bij een aloha van 0.05 , als groep $(B+C+D)$ vergeleken wordt met groep $A(p=0.08)$ of als groep $D$ vergeleken wordt met groep $(A+B+C)(p=0.08)$. Dit ligt anders bij de vergelijking van groep $(C+D)$ ten opzichte van $(A+B)$.

De odds ratio voor groep $(C+D)$ tegenover groep $(A+B)$ (het effect van de maandoverzichten) bedraagt $0.75 ; 95 \% \mathrm{BI}=0.58-0.96$. De Cook afstand bedraagt daarbij maximaal 0.05 .

\section{Kwallteit van de fixatie}

Voor dit kwaliteitskenmerk vinden wij in geen enkele subgroep enige systematische verbetering (tabel 8.5 ).

Fig. 8.4: Gemiddelde per groep (A, B, C. D) van de percentages uitstrijkjes met onvoldoende fixatie per arts in beide periodes $\|=$ basislijnperiode, $\|$ $=$ interventieperiode)

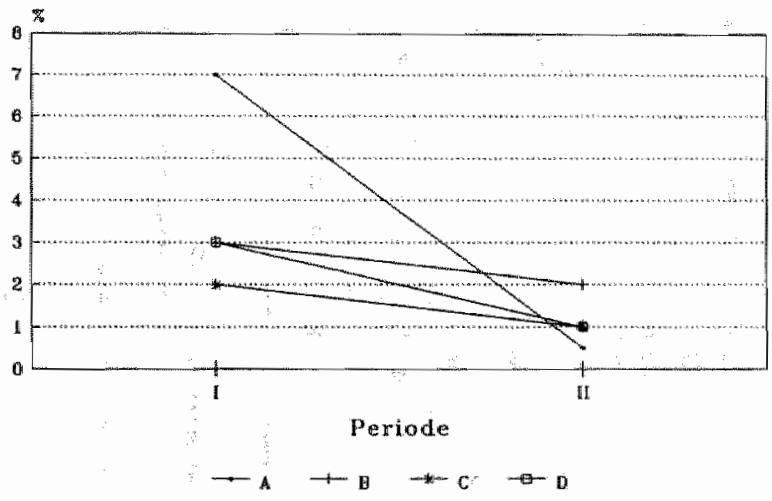

\section{Algemeen kwaliteitsoordeel}

Een duidelijke en systematische daling in het veranderingsquotiënt wordt gevonden bij gynaecologen, bij vrouwelijke artsen, bij artsen die voor wat betreftt de gebruik. te afnametechniek bij de restgroep ingedeeld zijn en bij de artsen met meer dan 50 uitstrijkjes tijdens de interventieperiode.

Het interventieverschil toont echter een grillig beeld: In geen enkele subgroep is er een systematische tendens terug te vinden.

Voor geen enkele subgroep is de Kruskall-Wallis significant en ook de MannWhitney testen voor elke interventiegroep en de controlegroep zijn nergens consistent significant (tabel 8.6). De correlatie blijkt alleen significant in de groep van artsen met meer dan 50 uitstrijkjes. 


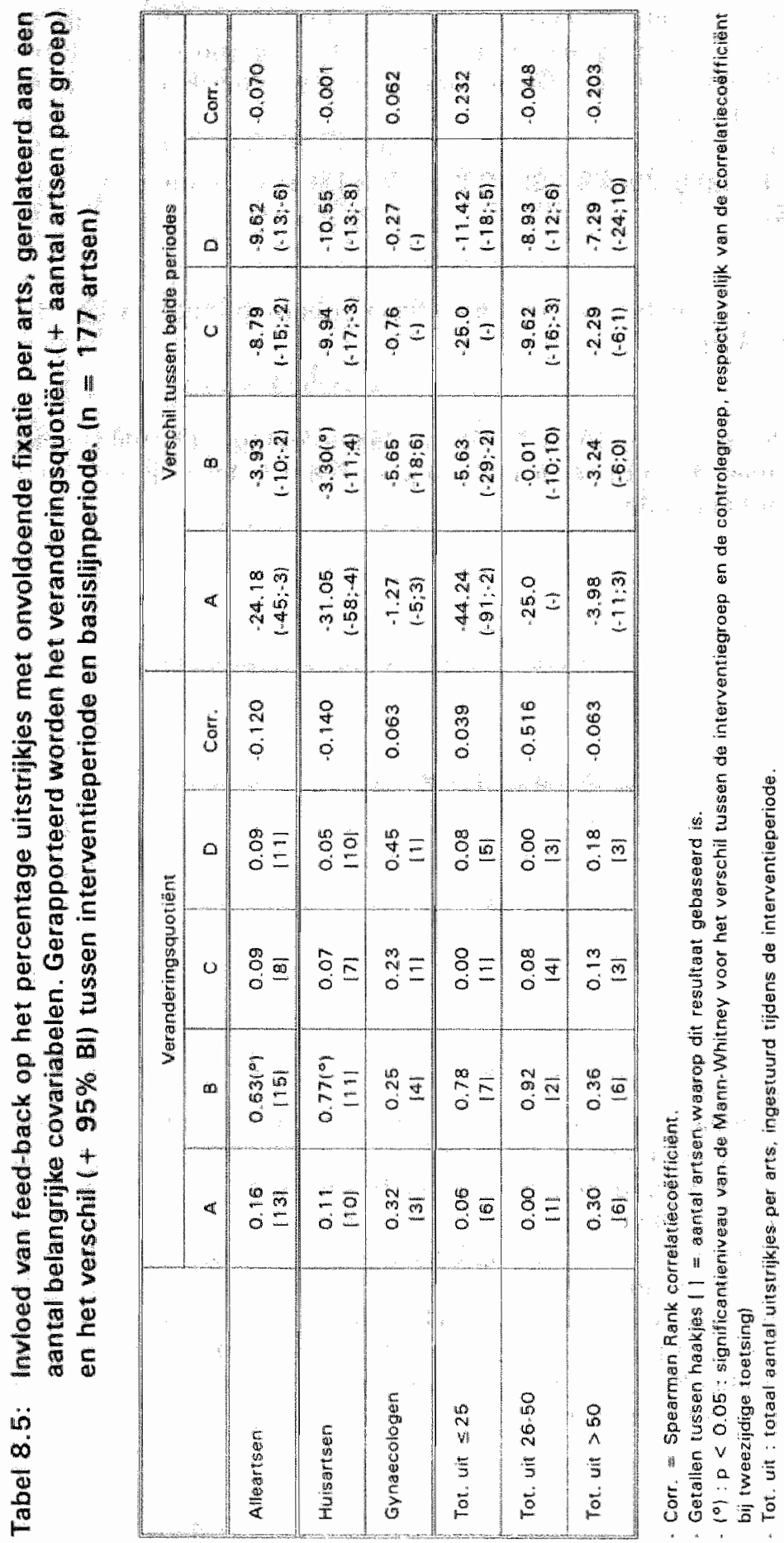


Fig. 8.5: Gemiddelde per groep (A, B, C, D) van de percentages uitstrijkjes met een algemeen kwaliteitsoordeel matig of slecht per arts in beide periodes (I $=$ basislijnperiode, $\|=$ interventieperiode)

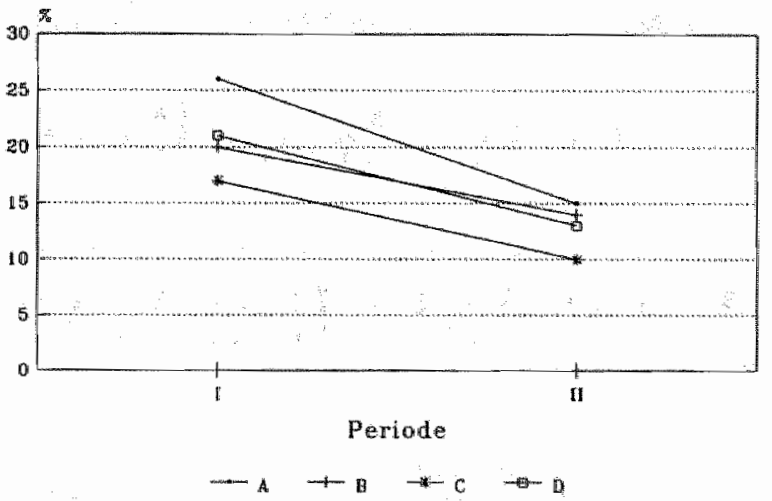

Afwijkende vitstrijkjes

Deze analyse gebeurde slechts op basis van de interventieverschillen vanwege het lage aantal artsen dat overbleef voor analyse van de veranderingsquotiënten na verwijdering van de artsen die tijdens de basislijnperiode geen enkel afwijkend uitstrijkje instuurden (tabel 8.7).

De niet significante maar systematische stijging in de toename van het aantal afwijkende uitstrijkjes, is blijkbaar volledig toe te schrijven aan de subgroep huisartsen. Zij kan in geen der andere geanalyseerde subgroepen gevonden worden.

Fig. 8.6: Gemiddelde per groep (A, B, C, D) van de percentages afwijkende uitstrijkjes per arts in beide periodes $(I=$ basislijnperiode, $I I=$ interventieperiode)

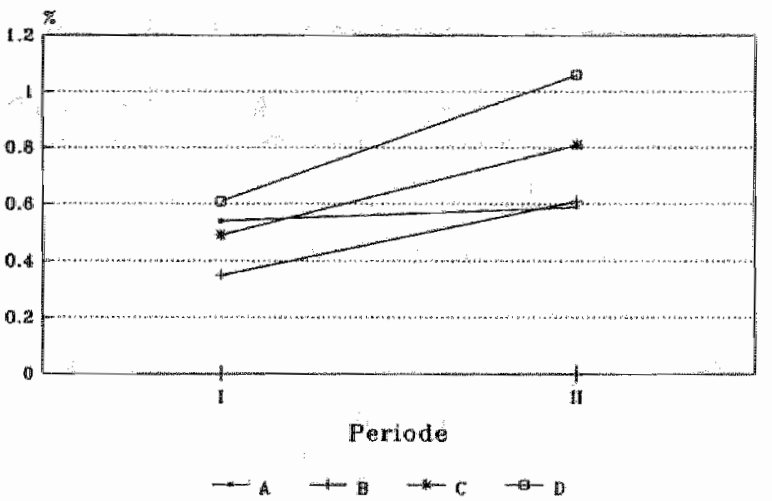




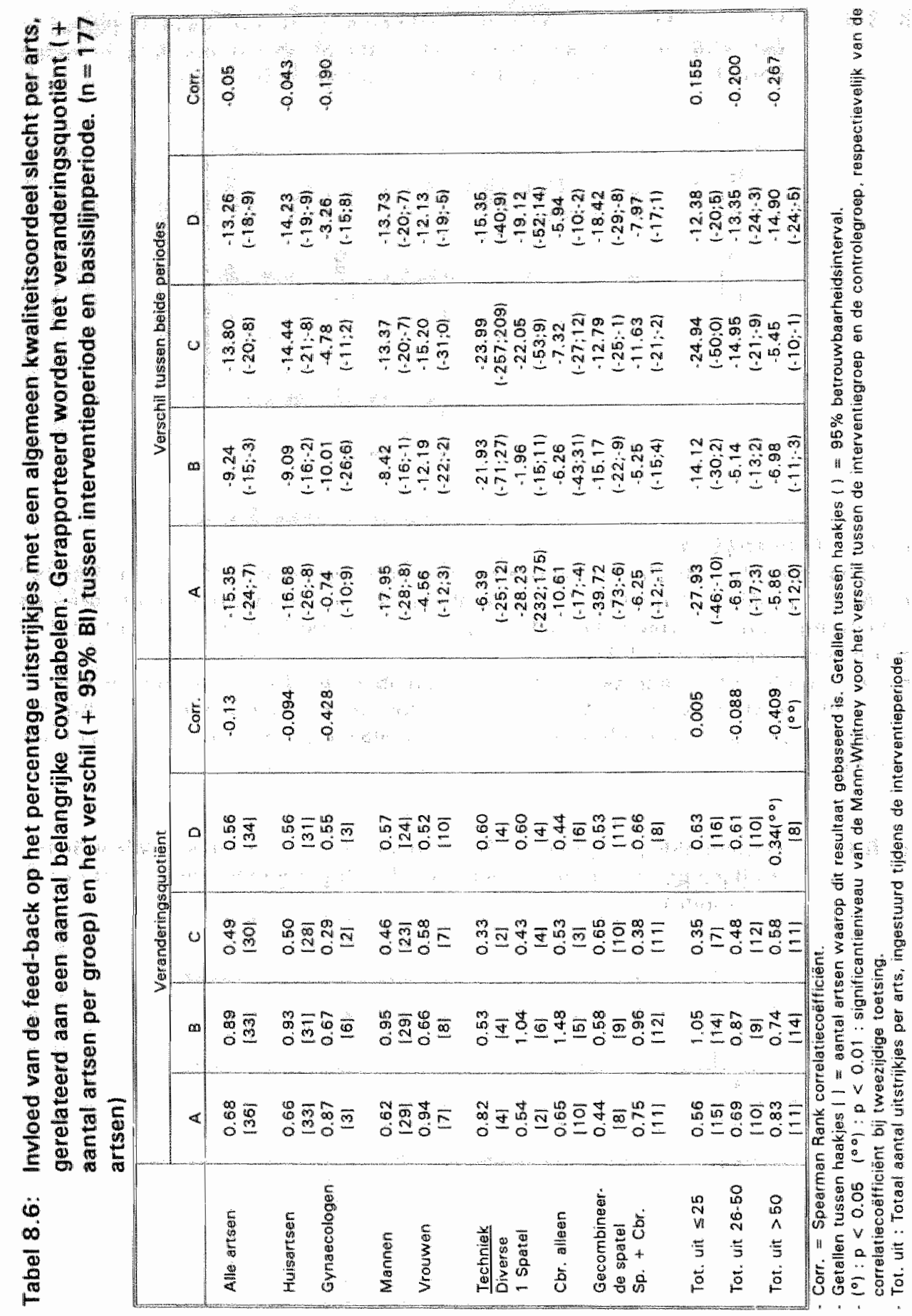


Tabel 8.7: Invloed van de feed-back op het percentage uitstrijkjes met lichte dysplasie of meer per arts, gerelateerd aan een aantal belangrijke covariabelen. Gerapporteerd wordt het interventieverschill (met aantal artsen per groep en $95 \%$ BI) tussen de interventieperiode en de basislijnperiode ( $n=177$ artsen)

\begin{tabular}{|c|c|c|c|c|c|}
\hline & \multicolumn{5}{|c|}{ Verschil tussen beide periodes } \\
\hline & A & $B$ & $\mathrm{c}$ & 0 & Corr. \\
\hline Alle artisen & $\begin{array}{r}+0.061451 \\
(-0.79: 0.901\end{array}$ & $\begin{array}{c}+0.25(46) \\
(-0.31 ; 0.81)\end{array}$ & $\begin{array}{c}+0.31142) \\
(-0.32 ; 0.96)\end{array}$ & $\begin{array}{r}+0.4414 .21 \\
(0.53 ; 11.401\end{array}$ & 0.010 \\
\hline Huisartsen: & $\begin{array}{c}0.06(42) \\
(-0.93 ; 0.83)\end{array}$ & $\begin{array}{r}+0.341401 \\
(-0.28,0.97) \\
\end{array}$ & $\begin{array}{c}10.251401 \\
(-0.41 ; 0.92)\end{array}$ & $\begin{array}{r}+0.431391 \\
(-0.67: 1.48) \\
\end{array}$ & 0.005 \\
\hline Gynaecologen & $\begin{array}{c}-1.62[3] \\
(-4.21 ; 7.44] \\
\end{array}$ & $\begin{array}{c}-0.3516] \\
(-1.68 ; 0.99)\end{array}$ & $\begin{array}{r}+1.57121 \\
(-3.87 .7 .01) \\
\end{array}$ & $\begin{array}{c}40.49 \mid 3) \\
(-1.62 ; 2.60)\end{array}$ & -0.053 \\
\hline To: wit $\leq 25$ & $0 \mid 221$ & $\begin{array}{c}0.24119\} \\
(-0.74 ; 0.26) \\
\end{array}$ & $\begin{array}{r}-0.03 \mid 751 \\
(1.30 ; 1.25)\end{array}$ & $\begin{array}{r}+0.991211 \\
10.41: 2.381\end{array}$ & 0.130 \\
\hline Tot wit $26-50$ & $\begin{array}{c}-0.981121 \\
(-4.00 ; 2.00)\end{array}$ & $\begin{array}{r}+0.26111 \| \\
\{-0.83 * 1.36\}\end{array}$ & $\begin{array}{r}+0.45\{14 j \\
\{0.52,1,4 i\}\end{array}$ & $\begin{array}{r}+0.13|13| \\
(-1.43,1.69)\end{array}$ & 0.050 \\
\hline Tot. wit $>50$ & $\begin{array}{r}+1.31(11) \\
(-0.23: 2,85)\end{array}$ & $\begin{array}{c}+0.83 \mid 151 \\
(-0.57: 2.23)\end{array}$ & $\begin{array}{c}+0.561131 \\
(0.78: 1.90)\end{array}$ & $\begin{array}{c}-0.57 \mid 81 \\
(-3.87 ; 2.86)\end{array}$ & .0 .144 \\
\hline
\end{tabular}

Corr. = Spearman Rank correfatiecoëfficiënt.

Getallen tussem haakjes ( ) = aantal artsen waarop dit resultaat gebaseerd is. Getallen tussar haakjes ()=95\% betrowwbearheidsinterval.

Tol, uit : Totaal antal uitstrijkjes per arts, ingestuturd tijens de interventieperiode.

Invioed van het aantal uitstrijkjes

Voor elk van de 4 onderzochte outcome parameters Iveranderingsquotiënt en interventieverschil voor de afwezigheid van endocervicale cellen en voor het aligemeen kwaliteitsoordeel) vinden wij slechts in interventiegroep D negatieve correlaties tussen het aantal ingestuurde uitstrijkjes en de onderzochte outcome parameter. Deze correlaties zijn echter klein en niet significant.

\section{Spreiding van de resultaten over de meewerkende arisen}

In alle groepen (incll. de controlegroep) vinden wij gedurende de interventieperiode een duidelijke daling van de variatiecoëfficiënt in vergelijking met de basislijnperiode voor de afwezigheid van endocervicale cellen, woor het algemeen kwaliteitsoor w deel en voor het percentage afwijkende uitstrijkjes. De significante correlatie tussen de som en het verschil van de gevonden waarde voor de basislijnperiode en voor de interventieperiode, die in alle groepen gevonden wordt voor vrijwel alle indicatoren wijst op een erg kleine kans dat deze dalingen door toeval verklaard kunnen worden (tabel 8.81. Er is geen duidelijke aanwijzing dat deze daling systematisch meer uitgesproken zou zijn in één of meerdere der interventiegroepen.

Voor de kwaliteit van de fixatie is de invloed van de interventie op de inter-dokter variatie wisselend van groep tot groep. 
Tabel 8.8: Verandering (tussen basisilinperiode en interventieperiode) in Interdokter variatie voor de vier interventiegroepen $(A, B, C, D)$

\begin{tabular}{|c|c|c|c|c|c|c|c|c|c|}
\hline \multirow[t]{2}{*}{$\bar{s}$} & \multirow[t]{2}{*}{ 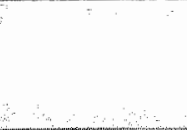 } & \multicolumn{2}{|c|}{$\mathrm{A}$} & \multicolumn{2}{|c|}{$\mathrm{B}$} & \multicolumn{2}{|c|}{$C$} & \multicolumn{2}{|c|}{0} \\
\hline & & $\begin{array}{c}\text { Batis. } \\
\text { lfin }\end{array}$ & $\begin{array}{l}\text { Interwen } \\
\text { ties }\end{array}$ & $\begin{array}{l}\text { Ba. } \\
\text { sisting }\end{array}$ & $\begin{array}{l}\text { Inter. } \\
\text { ventio }\end{array}$ & $\begin{array}{l}\text { atasis- } \\
\text { Ifn }\end{array}$ & $\begin{array}{l}\text { lnter. } \\
\text { wentie }\end{array}$ & $\begin{array}{c}\text { Basis. } \\
\text { lijin }\end{array}$ & $\begin{array}{l}\text { Initer. } \\
\text { vertitie }\end{array}$ \\
\hline \multirow{4}{*}{$\begin{array}{l}\text { Afvo of } \\
\text { zigh. } \\
\text { ondoc. } \\
\text { collen }\end{array}$} & $\begin{array}{l}\text { gemididale } \\
\text { slectit }\end{array}$ & 20 & 16 & 17 & 12 & 15 & 8 & 19 & 11 \\
\hline & $P 215-P 75$ & 0.33 & 4,20 & 0.30 & $4-16$ & 0.22 & $1-11$ & 6.31 & $9-14$ \\
\hline & $\begin{array}{l}\text { verschill }(\%) \\
\text { in } C\end{array}$ & \multicolumn{2}{|c|}{-5} & \multicolumn{2}{|c|}{$i 17$} & \multicolumn{2}{|c|}{0} & \multicolumn{2}{|c|}{-12} \\
\hline & p & \multicolumn{2}{|c|}{$<0,001$} & \multicolumn{2}{|c|}{$\angle 0.001$} & \multicolumn{2}{|c|}{$<0.001$} & \multicolumn{2}{|c|}{$<0.001$} \\
\hline \multirow{4}{*}{$\begin{array}{l}\text { Onwol } \\
\text { dmende } \\
\text { fixa. } \\
\text { to: }\end{array}$} & $\begin{array}{l}\text { glomidalda \% } \\
\text { stecht }\end{array}$ & 7 & $\therefore 0$ & 3 & 2 & 2 & 1 & 3 & 1 \\
\hline & P 25-P75 & 0.1 & 0.0 & 0.3 & $0-3$ & $0-0$ & 0.1 & 0.0 & 0.0 \\
\hline & $\begin{array}{l}\text { versehill } 1000 \\
\text { in } \varrho_{y}\end{array}$ & \multicolumn{2}{|c|}{-8} & \multicolumn{2}{|c|}{32} & \multicolumn{2}{|c|}{.36} & \multicolumn{2}{|c|}{21} \\
\hline & $p$ & \multicolumn{2}{|c|}{$<0.001$} & \multicolumn{2}{|c|}{0.050} & \multicolumn{2}{|c|}{0.82} & \multicolumn{2}{|c|}{$<0.001$} \\
\hline \multirow{4}{*}{$\begin{array}{l}\text { Algem. } \\
\text { kwal." } \\
\text { dor- } \\
\text { deall }\end{array}$} & $\begin{array}{l}\text { gamiddeatde } \\
\text { stecht }\end{array}$ & 26 & 16 & 20 & 14 & 17 & 10 & 21 & 13 \\
\hline & P 28-P75 & $5-33$ & 4.21 & $6 \cdot 32$ & $6-116$ & 0.25 & 2.13 & 6.33 & 7.17 \\
\hline & $\begin{array}{l}\text { vercohil } 1 \% \text { ) } \\
\text { in } \mathbb{C}_{4}\end{array}$ & \multicolumn{2}{|c|}{.5} & \multicolumn{2}{|c|}{.10} & \multicolumn{2}{|c|}{-9} & \multicolumn{2}{|c|}{.16} \\
\hline & $p$ & \multicolumn{2}{|c|}{$<0.001$} & \multicolumn{2}{|c|}{$\angle 0.001$} & \multicolumn{2}{|c|}{$<0.001$} & \multicolumn{2}{|c|}{$<0,001$} \\
\hline \multirow{4}{*}{$\begin{array}{l}\text { Afwij- } \\
\text { kende } \\
\text { uit. } \\
\text { str. }\end{array}$} & $\begin{array}{l}\text { gemiddelde \% } \\
\text { slecht }\end{array}$ & 0.54 & 0.58 & 0.35 & 0.61 & 0.49 & 0.81 & 0.61 & 1.06 \\
\hline & P25-P75 & 0.0 & 0.0 & 0.0 & 0.0 & 00 & 0.0 & 0.0 & $0-0$ \\
\hline & $\begin{array}{l}\text { varschil f } \\
\text { in } C\end{array}$ & & 3 & & & & & & \\
\hline & $p$ & & 001 & & & & & & \\
\hline
\end{tabular}

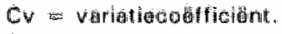

\% thacht parcantage uitstrijkjs per arts mat onvoldoende kwahteit woor hot betrokken criterium.

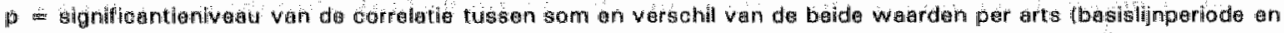
interventeperiodel. Zio mothoresectiv bij dir hoofdstuk.

\section{Resultaten op basis van de afzonderlijke uitstrijkjes}

De resultaten worden samengevat in tabel 8.9 .

Vergelijking van de percentages uitstrijkjes zonder endocervicale cellen in de interventieperiode met de basislijn geeft een duidelijke daling in alle groepen. Voor groep $C$ en $D$ is deze daling sterker in de interventiegraep dan in de controlegroep. Voor het geheel van de zes interventiemaanden en voor deze beide groepen samen bedraagt het veranderingsquotiënt voor de uitstrijkjes zonder endocervicale cellen 
0.50 (fig. 8.7). Wanneer wij de vergelijking maken met de inloopperiode in plaats van met de basislijn, bedraagt het veranderingsquotiênt 0.60 .

Tabel 8.9: Percentage uitstrijkjes van slechte kwaliteit (respectievelijk percentage afwijkende uitstrijkjesl per groep voor de verschillende kwaliteitskenmerken, ( $=17665$ uitstrijkjes)

\begin{tabular}{|c|c|c|c|c|}
\hline \multirow{2}{*}{ KWALITEITSCRITERUUM } & \multicolumn{4}{|c|}{ GROEP } \\
\hline & A & B & $c$ & $D$ \\
\hline $\begin{array}{l}\text { Endocervicale cellen } \\
\text { afwezig } \\
\% \text { basistlinperiode } \\
\% \text { interventieperiode } \\
\text { veranderingsquatient }\end{array}$ & $\begin{array}{r}13.5 \\
10.9 \\
0.81\end{array}$ & $\begin{array}{c}16.1 \\
11.4 \\
0.71 \\
\end{array}$ & $\begin{array}{l}12.0 \\
6.2 \\
0.52\end{array}$ & $\begin{array}{l}17.1 \\
8.2 \\
0.48\end{array}$ \\
\hline $\begin{array}{l}\text { Omwoldoende fixatie } \\
\text { \% basislijnperiode } \\
\% \text { interventieperiode } \\
\text { veranderingsquotiênt }\end{array}$ & $\begin{array}{l}1.8 \\
0.6 \\
0.27 \\
\end{array}$ & $\begin{array}{l}2.3 \\
0.9 \\
0.39 \\
\end{array}$ & $\begin{array}{l}1.2 \\
0.8 \\
0.65\end{array}$ & $\begin{array}{l}1.9 \\
0.8 \\
0.41\end{array}$ \\
\hline $\begin{array}{l}\text { Aflwijkenda cellen } \\
\text { \% basislitinperiode } \\
\% \text { interventieperiade } \\
\text { veranderingsquotient }\end{array}$ & $\begin{array}{l}0.84 \\
1.07 \\
1.26\end{array}$ & $\begin{array}{l}0.70 \\
1.00 \\
1.43\end{array}$ & $\begin{array}{l}0.46 \\
1.18 \\
2.64\end{array}$ & $\begin{array}{l}1.07 \\
1.07 \\
1.00\end{array}$ \\
\hline $\begin{array}{l}\text { Algameen kwaliteitsoor- } \\
\text { deel slecht } \\
\text { \% basistijnperiode } \\
\% \text { interventieperiode } \\
\text { weranderingsquotiönt }\end{array}$ & $\begin{array}{l}15.0 \\
11.5 \\
0.75\end{array}$ & $\begin{array}{c}18.0 \\
12.3 \\
0.68\end{array}$ & $\begin{array}{c}13.2 \\
7.3 \\
0.51\end{array}$ & $\begin{array}{l}18.8 \\
9.4 \\
0.47\end{array}$ \\
\hline
\end{tabular}

Fig. 8.7: Percentage uitstrijkjes zonder endocervicale en/of metaplastische cellen per groep $(A, B, C, D)$ in beide periodes $(I=$ basislijnperiode, U = interventieperiode)

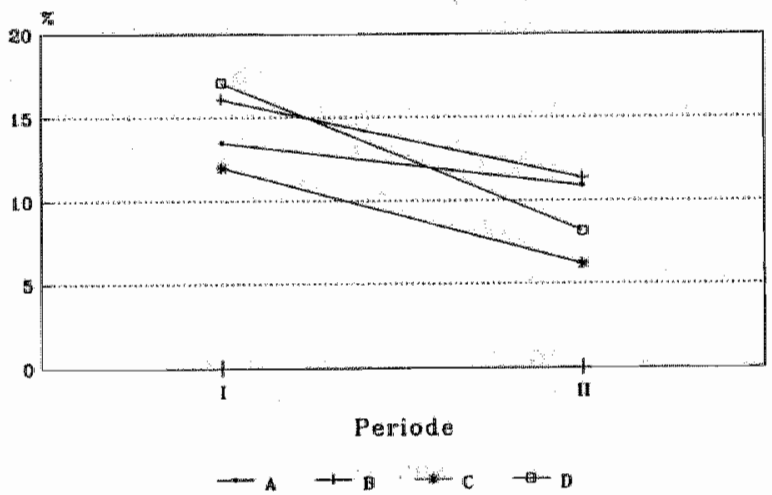


Het percentage uitstrijkjes met fixatieproblemen daalt in alle groepen vrijwel constant over de gehele onderzoeksperiode (fig. 8.8). Er wordt geen specifieke invloed vastgesteld van één der interventiemethoden.

Fig. 8.8: Percentage uitstrijkjes met onvoldoende fixatie per groep (A, B, C, D) in beide periodes $(I=$ basislijnperiode, $\|=$ interventieperiode)

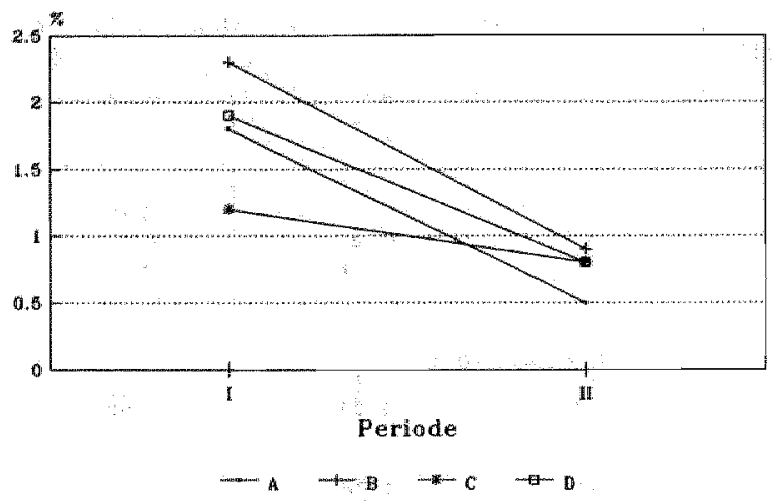

Vergelijking van de percentages uitstrijkjes met als algemeen kwaliteitsoordeel slecht geeft een duideliike daling in alle groepen. In groep C en D is deze daling duidelijk sterker dan in de controlegroep (fig. 8.9). Deze indicator volgt daarmee het patroon van de uitstrijkjes zonder endocervicalle cellen. Voor het geheel van de zes interventiemaanden en voor deze beide groepen samen bedraagt het veranderingsquotiënt 0.49 . Wanneer wij de vergelliking maken met de inloopperiode in plaats van met de basislijn, bedraagt dit veranderingsquotiënt 0.61 .

Fig. 8.9: Percentage uitstrijkjes met een algemeen kwaliteitsoordeel matig of slecht per groep (A, B, C, D), in beide periodes $(I=$ basislijnperiode, II = interventieperiode)

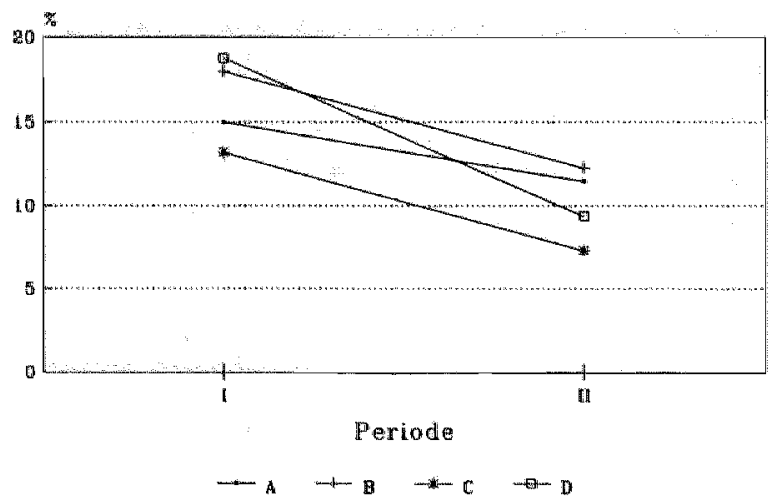


Er wordt geen duidelijke systematische stijging gevonden vary het percentage af wijkende uitstrijkjes ten opzichte van de basislijn, respectievelijk de inloopperiode (fig. 8.10) bij toenemende intensiteit van de interventie.

Fig. 8.10: Percentage afwijkende uitstrijkjes per groep $(A, B, C, D)$, in beide periodes $(1=$ basislijnperiode, $I I=$ interventieperiode $)$

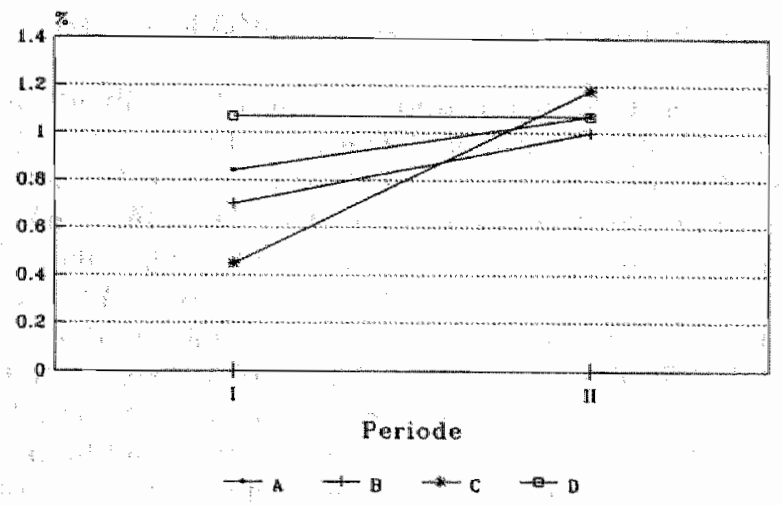

\section{DISCUSSIE}

Voor het geheel van alle artsen konden wij in dit onderzoek geen systematische invloed aantonen van feed-back op de gemiddelde veranderingsquotiënten of op de interventieverschillen per arts voor de drie onderzochte kwaliteitskenmerken. Wel is er een opvallende systematische toename in de stijging van het percentage afwijkende uitstrijkjes bij toenemende intensiteit van de interventies. De gevonden waarden zijn voor geen van de onderzochte groepen significant bij toetsing met Mann Whitney (0.95) of met Spearman Rank correlatie coefficiënt (0.116). Dit kan echter te wijten zijn aan het lage percentage afwijkingen dat eigen is aan cervix. screening. Om hierbij een stijging in het interventieeffect met $0.5 \%$, respectievelijk $1 \%$ statistisch significant te kunnen aantonen met een alfa fout van $10 \%$ en een beta-fout van $10 \%$ zouden immers 2373 , respectievelijk 739 artsen per groep vereist zijin.

Een stapsgewijs uitgevoerde multiple regressieanalyse geeft ons vergelijkbare resultaten voor de afname in het aantal uitstrijkjes zonder endocervicale cellen per arts, na correctie voor een groot aantal mogelijke confounders. De relatieve daling (uitgedrukt als het veranderingsquotiënt) is in groep $C+D$, de groepen die maandoverzichten ontvingen, $30 \%$ groter dan in groep $A+B 1 O R=0.75 ; 95 \% B 1=0.58$ 0.961 . Bij analyse per afzonderlijke interventiegroep bereikt deze afmamie statistische significantie in groep $\mathrm{C}$, maar in groep $\mathrm{D}$ verdwijnt deze weer. Er kan dus well gesproken worden van een trend, maar niet van een consequent effect. Gezien de 
randomisatie is er, naast toeval, overigens geen duidelijke oorzaak te bedenken waarom precies in groep $\mathrm{C}$ de beste resultaten gevonden worden.

Bij analyse van de subgroepen blijkt de stijging in thet aantal afwijkende uitstrijkjes vrijwel volledig terug te voeren op de subgroep huisartsen. Zij kan in geen enkele andere subgroep aangetoond worden. De systematiek in deze verbetering is opvallend. Het zou dan ook boeiend zijn om dit gegeven op een grotere groep huisartsen opnieuw te toetsen. Dit lijkt alleen mogelijk vila een groot opgezette multicenter studie, waarbij een groot aantal laboratoria uit Vlaanderen en/of Nederland gelijktijdig een dergelijke feed-back-methode invoert.

De analyse van het verbeteringspatroon voor de afwezigheid van endocervicale cellen in de verschillende subgroepen levert op thet eerste gezicht een nogal complex beeld op. Bij nader inzien is er echter toch een logische lijn in terug te vinden. De verbetering wordt vooral gevonden in die subgroepen, waarin zich de artsen bevinden die per tijdseenheid de meeste uitstrijkjes maken: artsen met meer dan 50 uitstrijkjes in de interventieperiode, gynaecologen en vrouwelijke artsen. Het zijn juist deze artsen die het vaakst hun feed-back onder ogen krijgen. Hun maandelijkse overzichten zijn op een groot aantal uitstrijkjes gebaseerd en kunnen dus in mindere mate aan toevall geweten worden. Deze artsen maken vrijwel dagelijks uitstrijkjes, zodat zij de lessen uit de verkregen feed-back meteen kunnen toepassen. Artsen die weinig uitstrijkjes maken daarentegen, krijgen ook zelden feed-back via de uitslagen van de door hen afgenomen uitstrijkjes. Wellicht zullen velen onder hen een eventueel slecht resultaat bij de maandoverzichten aan toeval toeschrijven en er dus verhoudingsgewijs weinig lering uit trekken. Het is ook niet uitgeslaten dat er juist bij artsen die minder uitstrijkjes maken ook minder interesse bestaat om zich in te spannen voor een kwalitatief goed resultaat. Bovendien krijgen zij pas na langere tijd de kans om de opgevangen boodschap in de praktijk toe te passen, zodat veel goede voornemens mogelijk opnieuw vergeten zijn.

Deze resultaten kunnen niet leiden tot een definitieve uitspraak $\mathbf{Z i j}_{\mathrm{ij}}$ vormen echter op zijn minst een aanwijzing dat feed-back, in de vorm van een schriftelijke kwaliteitsbeoordeling bij elke uitslag plus maandoverzichten, met vergelijking van de eigen resultaten met het gemiddelde voor de hele groep, een positieve invloed heeft op het percentage uitstrijkjes met endocervicale cellen. Dit geldt vooral als er per tijdseenheid voldoende uitstrijkjes gemaakt warden om de feed-back een kans te geven. De grens zou daarbij kunnen liggen rond 100 uitstrijkjes per jaar.

Er is geen systematische verbetering gevonden in de kwaliteit van de fixatie. Bij deze vaststelling moet wel rekening gehouden worden met het groot aantal artsen dat reeds in de basislijmperiode alleen goed gefixeerde uitstrijkjes inleverde en dus niet meer voor verbetering en dus ook niet voor de analyse per arts in aanmerking kiwam. Hierdoor is de power van dit onderdeel van de analyse sterk verminderd:

Het algemeen kwaliteitsoordeel is een somscore waarin de normafwijkingen verwerkt zijn van de verschillende kwaliteitskenmerken waaruit zij samengesteld is. Het is dary ook logisch dat het effect van feed-back op het algemeen kwaliteitsoordeel zich bevindt tussen de resultaten voor de andere kwaliteitskenmerken. Het gevolg daarvan is een moeilijk interpreteerbaar en niet systematisch effect. 
met veranderingsquotienten die in afgezwakte mate min of meer het patroon van de endocervicale cellen volgen en interventieverschillen waarin geen systematische en significante verbetering kan worden gevonden.

Ter informatie van beleidsverantwoordelijken werd ook nagegaan wat de invloed was van onze interventies, betrokken op het totaal aantal ingestuurde uitstrijkjes. en niet op de individuele artsresultaten. De gegevens suggereren voor deze analyse een duidelijke invloed van de feed-backmethode, met gebruik van maandelikse overzichten en vergelijking van de eigen resultaten met het gemiddelde voor de gehele artsengroep, zoals toegepast in groep $C$ en $D$, op het aantal witstrijkjes zonder endacervicale cellen (veranderingsquotiënt $=0.50$ ) en op het algemene kwaliteitsoordeel (veranderingsquotient $=0.49$ ). Deze effectgrootte is verge lijkbaar met wat elders met telefonische feed-back aan slecht scorende artsen bereikt werd in een gelijksoontige situatie (Boon e.a. 1986). Een dergelijke verbetering is niet gevonden voor de kwaliteit van de fixatie of voor het aantal afwijkende uitstrijkjes. Het toevoegen van niet meer dan een zimmetje met een kwaliteitsoordeel op elk protocol zou volgens deze gegevens slechts een marginal effect hebben. Deze resultaten komen overigens overeen met de bevinding dat het vooral veel uitstrijkende artsen zijn die profiteren van de feed-back. Het zijn immers ook deze artsen die de belangrijkste invloed uitoefenen op het totaal aantal gemaakte uitstrijkjes.

Bij iedere interventiestudie is het de moeite om na verloop van een langere followup periode na te gaan wat er van het effect overgebleven is. Het is dan ook de bedoeling om na enige tijd opnieuw de afnamekwaliteit bij deze artsen te analyseren.

Basisinformatie over een correcte uitstrijktechniek is noodzakelijk opdat feed-back enige invloed zou kunnen uitoefenen. Verschillende onderzoekers (Fraser e.a. 1987, Mitchell e.a. 1985, Soumerai e.a. 1990/ hebben gesuggereerd, dat informaw tieverstrekking en feed-back elkaars effect versterken. Daarom en om alle artsen bij de start qua informatie op een gelijk niveau te brengen, kreeg iedereen voor de start van de interventie een fotoreportage toegestuurd. Ook was er de mogelijkheid om een videoband aan te vragen. Daarvan werd intensief gebruik gemaakt, getuige het feit dat de 7 beschikbare banden constant uitgeleend waren.

Het effect van de fotoreportage kan slechts nagegaan worden in de controlegroep omdat het slechts daar de enige interventie is. De effectmeting gebeurde via een voor - na meting, welk design een vrij geringe bewijskracht heeft.

Binnen deze beperkingen merken wij in de periode na het rondsturen van de fotoreportage een opvallende en significante daling van het aantal kwalitatief slechte uitstrijkjes en een even opvallende, zij het niet significante stijging van het percentage afwijkende uitstrijkjes. Dit is een aanwijzing voor een mogelijk belangrijke invloed van het rondsturen van deze fotoreportage. Even opvallend daarbij is dat, met uitzondering van de kwaliteit van de fixatie laltijd al erg lage percentages) dit effect na 2 maanden opnieuw volledig verdwenen is.

Dit suggereert dat schriftelijke informatie een belangrijke, maar kortdurende invloed kan uitoefenen op de afnamekwaliteit van cervixuitstrijkjes en wellicht ook op andere factoren in het handelen van artsen, waarbij techmische kwaliteit een rol 
speelt. Dit komt overeen met ervaringen die elders beschreven zihn (Fraser e.a. 1987, Mitchell e.a. 1985).

Bij de analyse van onze gegevens vormden de artsen zonder uitstrijkjes van onvoldoende kwaliteit in de basislijnperiode een probleem: Zoals vermeld in de methode paragraaf is het immers voor deze artsen onmogelijk een veranderingsquotiêrnt te berrekenen.

Wij kozen voor het weglaten van deze artsen bij hiet berekenen van de quotiënten (niet voor de interventieverschillen). Dit is ook conceptueel correct: Het analyseren van de gegevens van artsen die nog voor verbetering vatbaar zijn past bij de practische situatie zoals die zich voordoet als kwaliteitsverbetering het streven is.

De door ons toegepaste interventie kost weinig ein is weinig arbeidsintensief. Het is belangrijk dat een interventie-effect niet hoofdzakelijk berust op het charisma of op een overmatig zware persoonlijke inzet van een programmaleider (Marton e.a. 1985): Ons systeem zou zonder meer over te nemen zijn door leder ander laboratorium of door welke andere screeningsinstantie dan ook.

Feed-back wordt geleidelijk meer en meer aangewend als middel tot kwaliteitsverbetering in het medisch handelen. $\mathrm{Er}$ is in de literatuur echter nog steeds een gebrek aan zorguuldig uitgewerkte en gecontroleerde trials waarin verschillende methoden uitgetest en vergeleken worden (Eisenberg e.a. 1981, Fraser e.a. 1987, Mitchell e.a. 1985). Met deze studie is getracht enigzins in deze leemte te voorzien. Er blijft echter behoefte aan gecontroleerd onderzoek naar het effect van vele andere varianten van feed-back en van andere interventiemethoden in allerlei aspecten van het medisch handelen en in verschillende settings. 


\section{REACTIE VAN ARTSEN OP VERSCHILLENDE VORMEN VAN FEED-BACK TER VERBETERING VAN DE AFNAMEKWALITEIT VAN CERVIXUITSTRIJKJES}

In aansluiting op het interventieonderzoek waarover in het vorig hoofdstuk gerapporteerd werd, is via een schriftelijke enquete nagevraagd hoe de betrokken artsen op de verschillende feed-backmethoden reageerden. Daarnaast is door een vergelijking van de antwoorden op twee telefonische enquêtes onderzocht in welke mate deze artsen tijdens de onderzoeksperiode wijzigingen aanbrachten aan de gebruikte afnametechniek.

Het krijgen van een kwaliteitsbeoordeling op het uitslagformulier en het ontvangen wan gericht advies werden door vrijwel alle artsen geapprecieerd. Maandelijkse overzichten van de bereikte afnamekwaliteit, met vergelijking van de resultaten wan iedere individuele arts met die van collega"s, werden door driekwart van de ondervraagde artsen op prijs gesteld.

Artsen die vaker uitstrijkjes van onvoldoende kwaliteit maken, zijn vaker dan gemiddeld geinteresseerd in verdere informatie, hulp en training.

Het aantal artsen dat bij het uitstrijken gebruik maakt van de gecombineerde spatel + Cytobrushmethode verdubbelde tijdens de onderzoeksperiode.

De inhoud van dit hoofdstuk is een bewerking van:

* Buntinx F., Crebolder H.F.J.M., Essed G.G.M., Knottnerus J.A. Reactions of doctors to various forms of feed-back designed to improve the sampling quality of cervical smears. Ter publicatie aangeboden. 


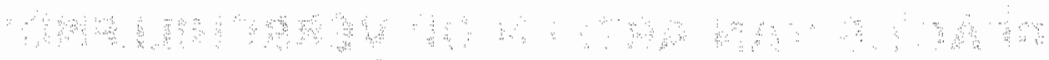

$$
\text { की }
$$

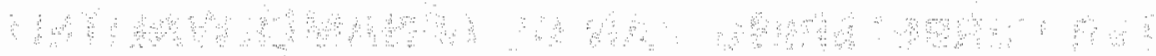

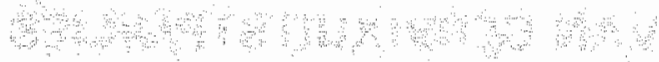

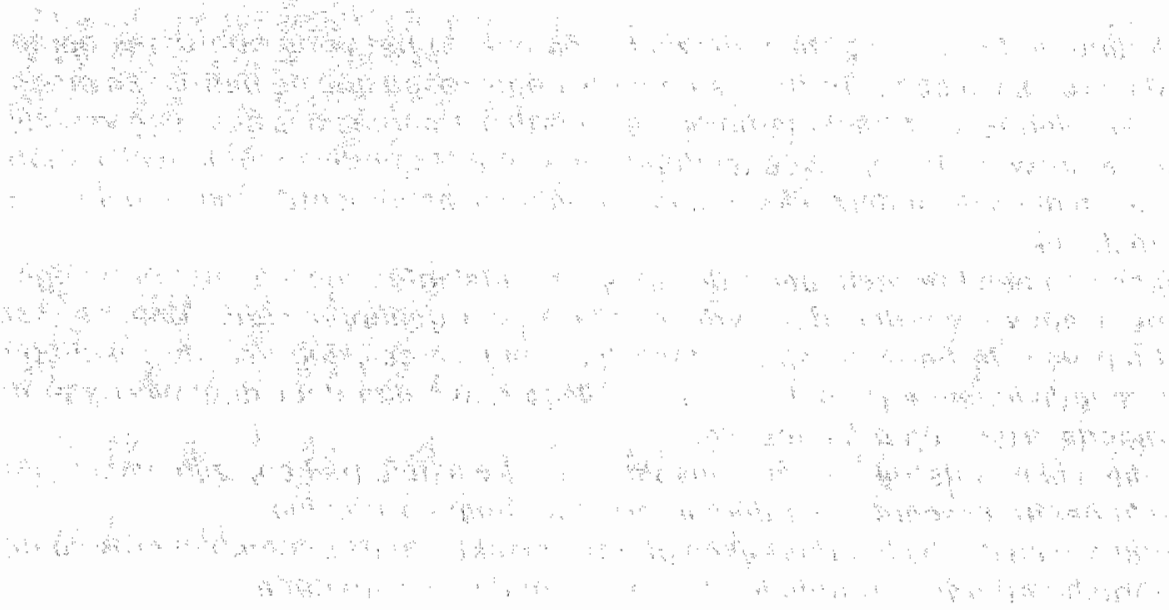




\section{INLEIDING}

Verschillende werkwijzen zijn gebruikt om de vaardigheden van artsen bij het maken van cervixuitstrijkjes te verbeteren. Het formuleren van goede richtlijnen, protocollen of standaarden (Buntinx e.a. 1989, Anonymus 1989, Baker 1989) is daarbij een belangrijke eerste stap. De implementatie daarvan is echter niet zo eenvoudig. Veel wordt daarbij verwacht van feed-back naar de uitstrijk (st)ers over de afnamekwaliteit van de door hen ingestuurde uitstrijkjes.

In verschillende centra is het ondertussen gebruikelijk om bij ieder uitstrijkje de afnamekwaliteit te evalueren of om tenminste het al dan niet aanwezig zijn van endocervicale cellen op het protocol te vermelden. Ook in de nieuwe Bethesdarichtlijnen is dit opgenomen.

Behalve een publicatie van Boon e.a. (Boon e.a. 1986) vonden wij in de literatuur echter geen evaluatie van het effect van vormen van feed-back op dit terrein (Boon e.a. 1989). Wij deden daarom een interventie-onderzoek waarbij feed-backmethoden van toenemende intensiteit op hun effectiviteit beoordeeld en onderling vergeleken werden (zie hoofdstuk 8).

$\mathrm{Na}$ afloop van het interventie-onderzoek waren wij benieuwd naar de wijze waarop de artsen de aan hen verstrekte vorm van feed-back ervaren en gewaardeerd hadden. Deze informatie is van belang om de viteindelijke acceptatie van een interventievorm te kunnen beoordelen en wij vonden hierover geen onderzoeksresultaten. Daarom rapporteren wij hier over de reacties van de artsen die met deze methoden geconfronteerd werden, zoals die blijken uit hun antwoorden op een schriftelijke enquête en over de veranderingen in afnametechniek die tijdens de onderzoeksperiode bij deze artsen optraden, zoals die blijken uit hun antwoorden op een telefonische enquête.

\section{METHODE}

\section{De feed-back}

Voor deze studie kwamen alle Nederlandstalige artsen in alanmerking die in de loop van het voorgaande jaar tenminste 20 uitstrijkjes voor cytologisch onderzoek aanboden aan het Centraal Laboratorium te Antwerpen.

Van 1 juni 1989 tot 30 april 1990 werd van ieder aangeboden uitstrijkje een gedetailleerde kwaliteitsbeoordeling gemaakt volgens vijf op voorhand gedefinieerde criteria. Gedurende een inloopperiode van drie maanden werd deze beoordeling alleen intern geregistreerd. Voor de uitstrijkende arts veranderde er in deze periode niets. Hij kreeg zoals steeds van ieder uitstrijkje het gebruikelijke protocol toegestuurd met de beschrijving van het beeld en de uitslag in PAPklasse.

Voor het begin van de interventieperiode ontvingen alle artsen een overdruk van een fotoreportage over de correcte afnametechniek van een cervixuitstrijkje met. verschillende mogelijke afname-instrumenten (Zie bijlage 1 ). 
De betrokken artsen werden vervolgens at random ingedeeld in vier groepen. De randomisatie gebeurde gestratificeerd (Pocock 1983) naar de discipline (huisarts of gynaecoloog/, naar het aantal gemaakte uitstrijkjes in het voorgaande jaar en naar de gebruikelijke afnametechniek, op basis van door de computer gegenereerde toevalsgetallen.

Na de inloopperiode werd, afhankelijk van de groep waarbij de uitstrijkende arts was ingedeeld, een continu voortdurende interventle verricht. De effectieve interventieperiode duurde 6 maanden.

\section{GROEP A:}

Voor de artsen uit deze groep veranderde er verder niets. Zif kregen zoals steeds voor leder uitstrijkje het gebruikelijke protocol.

Deze groep diende als controlegraep voor het interventieeffect.

\section{GHOEP B:}

Op basis van de bevindingen bij de interne kwaliteitsbeoordeling, werd aan leder protocol een extra zin toegevoegd "De technische kwaliteit van dit uitstrijkje was uitstekend, matig, onvoldoende". Bij een onvoldoende beoordeling wordt hieraan toegevoegd: "omwille van ..." Deze zin kon bijvoorbeeld als volgt worden afgemaakt: "onvoldoende endocervicalen" of "te veel bloedbijmenging".

\section{GROEP C:}

Idem als B. Daarenboven werd maandelijks per arts een overzicht toegestuurd van de kwaliteitsbeoordelingen over de voorbije maand, vergeleken met het gemiddelde van de totale groep.

\section{GAOEP D:}

Idem als C. Daarenboven ontvingen deze artsen, wanneer daartoe aanleiding was, gerichte voorlichting, waarbij de vastgestelde tekorten vertaald werden in adviezen voor hun technisch handelen in en verwijzing naar gerichte nascholingsvormen.

\section{De enquête}

Alle 179 artsen die bij de interventiestudie betrokken waren, kregen twee maanden na het afsluiten van de registratieperiode een enquêteformulier toegestuurd met het verzoek dit in te vullen en achteraf vil de ophaaldienst van het laboratorium terug te bezorgen. Wie niet antwoordde kreeg eenmaal een herhalingsformulier. Er waren 4 typen van vragenlijsten eén voor ledere interventiegroep. De vragen waren zodanig opgesteld dat zij gelijk waren voor iedereen die een bepaalde interventie wel, respectievelijk hiet ondergaan had. De mensen uit groep $B, C$ en D kregen zo dezelfde vragen naar hun mening over het hen ondertussen bekende commentaarzinnetje bij elk protocol en naar de wenselijkheid om dit gebruik in de toekomst voart te zetten. Aan de mensen uit groep A daarentegen werd gevraagd of zij een dergelijk zinnetje bij het protocol op prijs zouden stellen.

De vragenlijst peilde per feed-backmethode of artsen de betrokken techniek zinvol vonden en of zij dit in de toekomst ook op prijs zouden stellen. Daarnaast waren 
er wijf open vragen die de artsen de kans gaven om wrij commentaar te leveren. Wij rapporteren hiervan alle opmerkingen die tenminste door 3 artsen gemaakt werden.

De vragenlijsten werden terugbezorgd door 144 artsen of $80 \%$ van het totaal aantal aangeschreven artsen. Het percentage gynaecologen dat de vragenlijst terugbezorgde was $53 \%$. Mede vanwege dit geringe aantal antwoordende gynaecologen ( $n=8$ ) werd er dan ook beslist geen verschilen naar de discipline van de uitstrijkendle arts in deze analyse te betrekken. Er was geen significant verschil in respons volgens het geslacht van de arts $(p=1.00)$, het aantal uitstrijkjes gemaakt op jaarbasis $(p=0.43)$ of de indeling van de arts bij éen van de interventiegroepen $(p=0.83)$. Invloed van thet aantal jaren praktijkervaring is niet helemaal uit te sluiten $(p=0.05)$.

De toetsing van verschillen tussen groepen geschiedde met de chi ${ }^{2}$ test, waar nodig na categorisatie van een continue variabele. Waar er sprake was van een 2 × 2 tabel, werd gebruik gemaakt van de Yates-correctie.

De relatie tussen het al dan niet vragen om extra ondersteuning en het percentage kwalitatief slechte uitstriikjes in de interventieperiode werd tevens getoetst met een $\mathrm{Chi}^{2}$ test for trend met als nulhypothese de afwezigheid van een trend. Daarbi] werden alleen de "ja" of "neen" antwoorden gebruikt en de voor deze vraag niet ingevulde formulieren werden als "missing" buiten beschouwing gelaten.

\section{Wijzigingen in het gebruikte afnamemateriaal}

De artsen uit dit onderzoek waren zowel tijdens de registratieperiode als ervoor en erna volledig. vrij te kiezen welke afnametechniek zij gebruikten. Ook via de thun verstrekte feed-back werden zij niet expliciet onder druk gezet om een bepaalde afnametechniek te gebruiken. De artsen die ingedeeld waren in groep D kregen bij de feed-back met betrekking tot het voorkomen van endovervicale cellen wel de mededeling dat het gebruik van de Cytobrush een belangrijk hulpmiddel kan zijn bij het maken van uitstrijkjes met endocervicale cellen.

Na het afsluiten van de interventieperiode werd bij elk van de artsen opnieuw telefonisch nagevraagd welke op dat ogenblik de gebruikelijke afnametechniek was. Van 168 artsen $(94 \%)$ kregen wij een antwoord op deze vraag. De resultaten werden vergeleken met de antwoorden van deze artsen op de identieke telefonische vraag vóór het begin van het onderzoek. Daarbij waren wij met name geimteresseerd in het percentage artsen dat van een andere afnametechniek overschakelde op de gecombineerde spatel + Cvtobrushmethode. Deze methode blijkt uit het literatuuronderzoek immers als de kwalitatief beste naar voren te komen. De relatie tussen de interventie en de omschakeling vari andere afnametechnieken naar de gecombineerde spatel + Cytobrushafname werd getoetst met een $\mathrm{Chi}^{2}$ for trend toets. Als nulhypothese gold daarbij de afwezigheid van een trend. 


\section{RESULTATEN}

\section{Reacties op de feed-back}

Er waren 105 artsen die bij een van de drie actieve interventiegroepen hoorden en dus het extra zinnetie bij leder protocol kregen. Allemaal verklaarden zij deze verandering opgemerkt te hebben.

Tabel 9.1: Waardering van verschillende feed-back technieken door artsen die daar al dan niet ervaring mee hebben opgedaan

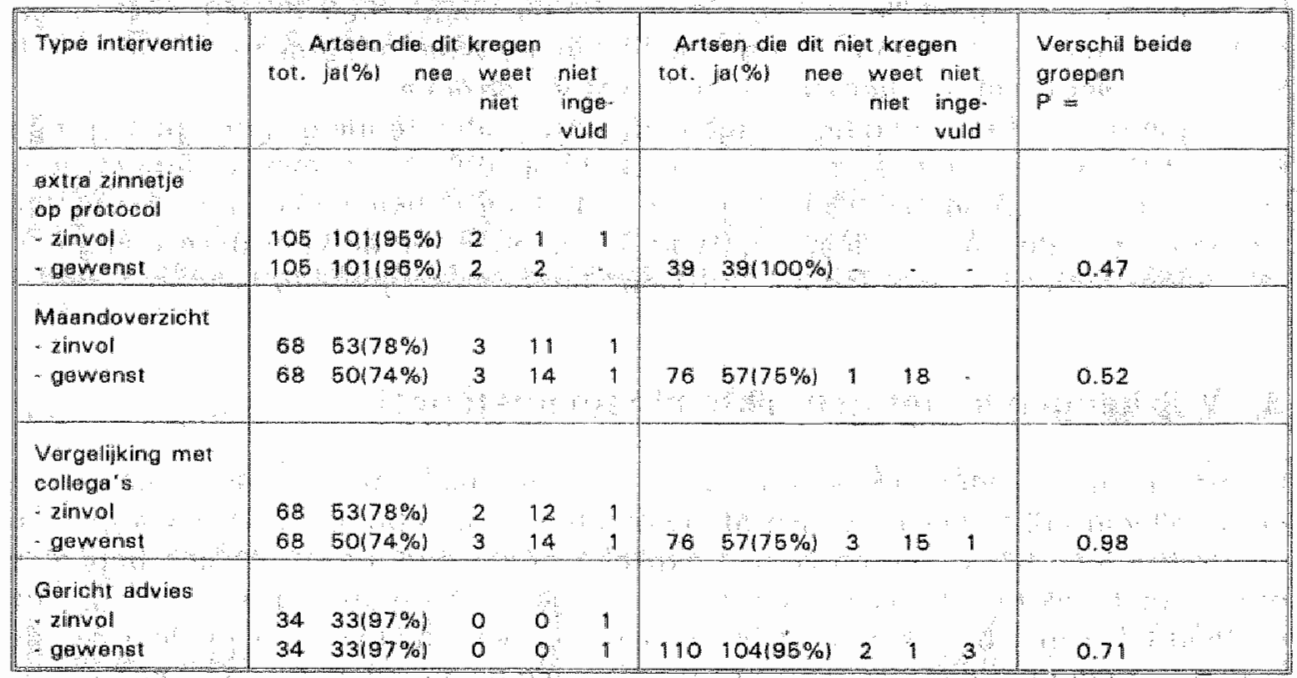

Zowel het extra zinnetje bij het protocol (groep B, C, D) als het gerichte advies op indicatie (groep DI worden door bijna alle artsen gewaardeerd en ook in de toekomst gewenst. Voor de maandoverzichten en voor de vergelijking van de eigen resultaten met die valn collegae (groep C, D) is dit minder het geval. Deze worden gewaardeerd en gewenst door ongeveer driekwart van de betrokken artsen (tabel 9.1).

Er is in deze antwoorden geen verschil tussen de artsen die tijdens de inloopfase van het onderzoek meer versus minder dan het gemiddelde percentage kwalitatief goede uitstrijkjes maakten. De wensen van de artsen die reeds met een bepaalde interventietechniek kennis malakten komen zeer nauw overeen met de wensen van artsen die de betrokken techniek slechts uit de beschrijving in de vragenlijst kennen.

\section{Interesse in verdere informatie of hulp}

105 Artsen (59\%) beantwoordden de vraag of verdere informatie of hulp gewenst was. Daarvan reageerden er $51147 \%$ wan de respondenten, of $28 \%$ van alle 
aangeschreven artsen positief. Wij vonden hierbij geen significant verschiltussen mannelijke en vrouwelijke artsen of tussen leden en niet-leden van de wetenschappelijke vereniging van Vlaamse huisartsen.

Tabel 9.2: Interesse in verdere hulp bij het correct afnemen van cervixuits trijkjes (n $=179$ )

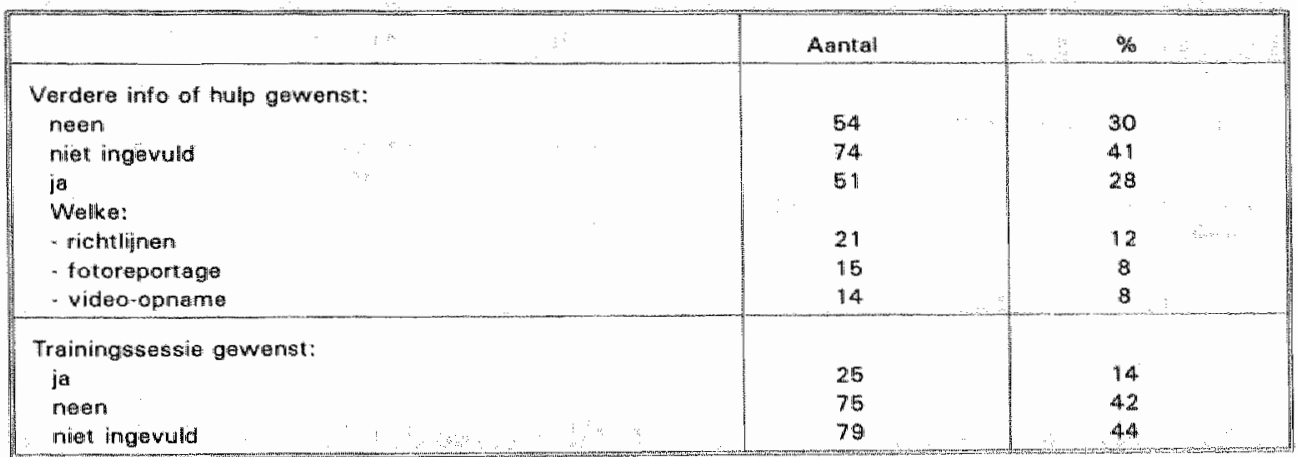

Artsen die een groter percentage kwalitatief slechte uitstrijkjes maken tijdens de laatste 6 maanden van het onderzoek, vragen ook vaker om verdere informatie of hulp $\left(p=0.025\right.$ en voor de $C h i^{2}$ voor trend: $\left.p=0.14\right)($ tabel 9.3$)$.

Door 25 artsen wordt gevraagd naar een trainingssessie (tabel $9.2 \%$. Hierbij was er geen verschil tussen leden en niet leden van de wetenschappelijke vereniging. Vrouwelijke artsen vragen echter in $44 \%$ naar een speciale trainingssessie tegenover $10 \%$ voor mannelijke artsen ( $p<0.001$ ). Artsen die een groter percentage kwalitatief slechte uitstrijkjes maken, vragen ook vaker naar een speciale trainingssessie (tabel $9.3 p=0.006$ en voor de $\mathrm{Chi}^{2}$ voor trend: $p=0.16$ ).

\section{Vrij commentaar}

Drieëndertig artsen of ruim éen op vijf maakten gebruik van de mogelijkheid tot het geven van vrij commentaar:

In zeven gevallen werd daarbij bezorgdheid geuit over de mogelijkheid dat op het uitslagformulier vermeld staat dat het uitstrijkje van onvoldoende kwaliteit is. Een aantal artsen blijken het formulier aan patiënten mee te geven en gvnaecologen sturen het soms op aan de huisarts van hum patiënten. In beide gevallen wordt niet op prijs gesteld dat te duidelijk een onvoldoende afnamekwalitelt vermeld staat. Eén arts wijst ook op mogelijke juridische consequenties.

Er wordt dan ook voorgesteld de beoordeling van de afnamekwaliteit op een afzonderlijk formulier te vermelden.

Vijf artsen doen voorstellen ter verbetering van de terminologie, zodat zij voor de patiënten duidelijker en relevanter wordt. Er wordt ook tweemaal voorgesteld een 
herhalingsadwies op het protocol te vermelden: "Zo weet patiente wat er van haar verwacht wordt".

Tabel 9.3: Aantal $(\%)$ artsen dat al dan niet verdere informatie c.q. een trailningssessie wenst in relatie tot het percentage kwalitatief slechte uitstrijkjes.

\begin{tabular}{|c|c|c|c|c|}
\hline $\begin{array}{l}\text { Percentage hwaltatef shehte } \\
\text { uatstrikjes }\end{array}$ & 0.5 & $6 \cdot 20$ & $21-100$ & Totaal \\
\hline \multicolumn{5}{|l|}{ Vraag naar verder informatie } \\
\hline ja & 101291 & 201271 & $17\{57\}$ & $47(34)$ \\
\hline ineen: & $12|34|$ & $34(40)$ & 91301 & $55(40)$ \\
\hline niet ingovulld & $13 \mid 37\}$ & $20127)$ & $4(13)$ & $37(27)$ \\
\hline totaal & $35 \| 100$ & $74(100)$ & $30: 100:$ & $139(100)$ \\
\hline $\begin{array}{lc}c h^{2}=11.08 & p=0.025 \\
c h^{2} \text { voor trend }=2.22 p=0.14\end{array}$ & & & & \\
\hline \multicolumn{5}{|l|}{ Vraag nuar trainingssesisies } \\
\hline fa & $3(9)$ & $11(15)$ & $9(30)$ & $23(17)$ \\
\hline noon : & $14(40)$ & $43(58)$ & $17(57)$ & $74(63)$ \\
\hline niest ingevuld & $18(51)$ & $20(27)$ & $4(3)$ & $42(30)$ \\
\hline total & 3511001 & $74(100)$ & $30(100)$ & $139 \| 100\}$ \\
\hline $\begin{array}{l}\text { Chi }^{2}=14.69 \quad p=0.006 \\
\text { Chir yoortrend }=1.94 \quad p=0.16\end{array}$ & & $\because \because$ & $\because$ & $\therefore$ \\
\hline
\end{tabular}

Een aantal artsen maakt van de gelegenheid gebruik voor het stellen van algemeen informatieve vragen $(6 x)$ rond het maken van cervixuitstriikjes (heeft een derde uitstrijkje zin? wat is het beste fixeermiddel?), of voor vragen naar de gebruikte criteria $(3 x)$.

Nogal wat artsen maken de terechte opmerking dat het in een aantal gevallen technisch vrijwel onmogelijk is om endocervicale cellen in het uitstrijkje te verkrijgen $(6 x)$. Zij wijzen er ook op dat artsen om psychologische redenen uitstrijkjes naar het laboratorium sturen, waarvan zij op voorhand vrijwel zeker zijn dat de $k$ waliteit onvoldoende is.

Er wordt voorgesteld bil de feed-back (evaluatie?) rekening te houden met eventueel vermelde afnameproblemen of macroscopische gegevens,

\section{Wijzigingen in het gebruikte afnamemateriaal}

Bijna de helft van de betrokken artsen (81/168) zegt in de periode tussen de twee telefoongesprekken van afnametechniek veranderd te zijn. Veranderingen vinden in geringe mate in alle richtingen plaats (tabel 9.4). Het gebruik van de spatel + Cytobrushmethode neemt echter toe van $33 \%$ voor de studie to $66 \%$ na de studie. 
Tabel 9.4: Gebruikelijke afnamemethode bij het maken van cervixuitstrijkjes voor en na een periode van 6 maanden waarin verschillende methoden van feed-back toeglepast werden

\begin{tabular}{|c|c|c|c|c|c|c|}
\hline Voor W Wa & $\begin{array}{c}\text { Diverse } \\
\quad:\end{array}$ & 1 Spatal & $\begin{array}{l}\text { Cytobrush } \\
\text { alleen }\end{array}$ & $\begin{array}{l}\text { Spatal } \\
\text { seherp } \\
\text { stomp }\end{array}$ & $\begin{array}{l}\text { Sparal } \\
\text { Cyrobrust } \\
\text { of }\end{array}$ & $\begin{array}{l}\text { Totalal } \\
\text { : }\end{array}$ \\
\hline Diverse & 0 & 4 & 6 & 0 & 111527 & 21 \\
\hline 1 Spatell & 0 & 4 & 1 & 5 & $10(48)$ & 20 \\
\hline Cytobrush atleer & . & 0 & 19 & 0 & 121344 & 32 \\
\hline Spatel scherp + stomp & 1 & 0 & 2 & 11 & $25|63|$ & 39 \\
\hline Spatel + Crtobrush & 1 & 0 & 0 & 2 & $53(95)$ & 56 \\
\hline Totaal & 3 & 8 & 28 & 18 & $111(66)$ & 168 \\
\hline
\end{tabular}

Deze toename is vooral uitgesproken in groep $C$ en $D$ (tabel 9.5 .

Tabel 9.5: Aantal artsen dat gebruilk maakt van de combinatie Spatel + Cytobrush voor en na de onderzoeksperiode volgens de interventiegroep waartoe ziji behoorden $(n=168)$

\begin{tabular}{|c|c|c|c|c|}
\hline Groep & A & $B$ & C & $D$ \\
\hline $\begin{array}{l}\text { interwentie } \\
\cdots\end{array}$ & $\begin{array}{l}\text { geen lcantrolel: } \\
\qquad(\%)\end{array}$ & $\begin{array}{l}\text { zinnorie bil elk } \\
\text { protoool } \\
\text { n } 1 \% 1 \%\end{array}$ & 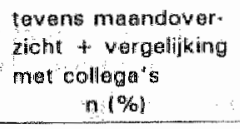 & $\begin{array}{l}\text { tawens grachent ad- } \\
\text { vies } \\
\qquad n|\%|\end{array}$ \\
\hline Aantal artsen & $44(100)$ & $42(100)$ & $41(100)$ & 411100 \\
\hline $\begin{array}{l}\text { Wót het onder- } \\
\text { zosk }\end{array}$ & $16(34)$ & $\quad 14(33)$ & $14(34)$ & 121291 \\
\hline Nla het onderzoek & $28(64)$ & $25(60)$ & $28(58)$ & $29(71)$ \\
\hline $\begin{array}{l}\text { Proportionile tore- } \\
\text { name (na/woorl }\end{array}$ & $\times 1.88$ & $\times 1.79$ & $\times 2.00$ & $\times 241$ \\
\hline
\end{tabular}

Chi for triend $=0.087\{(\hat{p}=0,36\}$

\section{DISCUSSIE}

Ondanks het feit dat de betrokken artsen niet op voorhand geïnformeerd waren, is het experiment met verschillende vormen van feed-back vrijwel unaniem goed ontwangen.

Bij de analyse van de verschillende methoden van feed-back is er een opvallend onderscheid. De meer klassieke techinieken (meedelen van de kwaliteitsbeoordeling en gericht advies) worden door vrijwel iedereen geapprecieerd. De maandoverzichten en een vergelijking van de eigen resultaten met die van collegae, worden slechts 
doar drie op wier artsen op prijs gesteld. Mogelijk worden deze technieken als vreemder of zelfs als meer bedreigend beoordeeld. Alleszins blikt het feit dat een bepaalde arts zelf beter of slechter dan het gemiddelde scoort hierbij geen rol te spellen. Het feit dat alle feed-backtechnieken hoge appreciatiecijfers krijgen suggereert dat de factor sociale wenselijkheid bij deze antwoorden een belangrijke; zij het niet meetbare, rol speelt. Daarom zijn ook de verschillen tussen de reacties op verschillende feed-backmethoden hier wellicht belangrijker dan de absolute waardien van deze reacties.

Het heeft ons enigszins verbaasd dat de antwoorden van degenen die ervaring opgedaan hebben met eeri bepaalde methode vrijwel identiek zijn aan de antwoorden van hen die deze methode alleen uit een korte beschrijving kennen. Blijkbaar kumnen artsen zich op basis van een beschrijving vrij precies voorstellen wat dit voor hen betekent. Deze vaststelling kan belangrijk zijn voor mensen die in de toekomst andere interventies voorbereiden.

Artsen die vaker kwalitatief slechte uitstrijkjes maken, vragen ook inderdaad vaker naar verdere informatie en hulp (57\% in de slechtste groep) of naar een trainingssessie $(30 \%$ in de slechtste groep). Het is geruststellend dat een belangrijk deel van deze artsen inzicht heeft in zijn/haar problemen en naar oplossingen blijkt te zoeken. Het is niet duidelijk in welke mate de feed-back die de meeste van deze artsen in de voorafgaande maanden ontvingen, hiertoe heeft bijgedragen.

De bevinding dat vrouwelijke artsen viermaal vaker naar een trainingssessie vragen kan het gevolg zijn van het feit dat vrouwelijke artsen gemiddeld meer uitstrijkjes maken dan hun mannelijke collega's, en dus vaker met de problematiek geconfronteerd worden. In een beschrijvend onderzoek, bij ongeveer dezelfde groep artsen die ook in dit onderzoek betrokken was, vonden wij geen aanwijzingen voor een kwaliteitsverschil volgens het geslacht van de uitstrijkende arts.

De invloed van de discipline van de uitstrijkende arts (huisarts of gynaecoloog) op de antwoorden werd in deze analyse niet nagegaan vanwege het lage aantal gynaecologen dat deze vragenlijst beantwoordde.

Zonder dat er daarop gerichte interventies verricht werden, blijkt een groot aantal

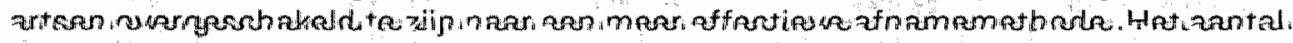
artsen dat de combinatiemethode gebruikt blijkt bij de tweede telefonische bevraging verdubbeld.

Er moet ook hierbij rekening gehouden worden met de mogelijkheid van sociaal wenselijke antwoorden. Bij de tweede telefonische ondervraging waren de betrokken artsen limmers vili gedetalleerd op de hoogte van het lopend onderzoek. Het is niet na te gaan in welke mate dit de antwoorden beïnloed heeft.

De toename vindt in alle groepen plaats, inclusief de controlegroep, en is dus zeker niet zonder meer aan de feed-back interventies toe te schrijven. De aan iedereen rondgestuurde fotoreportage en de informatie die artsen uit verschillende bronnen bereikt, hebben hier wellicht in belangrijke mate toe bijgedragen.

Toch is er een (niet significantel positieve trend waarneembaar in het percentage artsen dat overschakelt naarmate de intensiteit van de feed-back toeneemt. Dilt suggereert een verband tussen de twee interventies waarin met maandoverzichten gewerkt werd en voorall de laatste interventie waarin ook gericht advies gegeven werd, en de kans op omschakeling naar een effectievere afnamemethode. 


\section{DEEL III}

PLAVEISELCELLEN IN CERVIXUITSTRIJKJES 


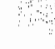
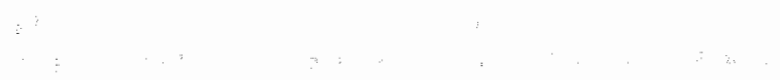

B $\mathrm{Ba}$

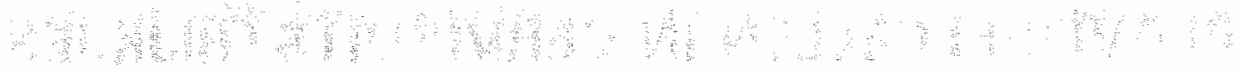


HOOFDSTUK 10

\section{VOORKOMEN VAN VERSCHILLENDE CELTYPEN IN UITSTRIJKJES, AFGENOMEN MET DE SPATEL, DE CYTOBRUSH EN DE COMBINATIE VAN SPATEL EN CYTOBRUSH}

Om na te gaan of een Cytobrushafname alleen volstaat voor het maken van een betrouwbaar cervixuitstrijkje werden $444_{x_{\text {}}}$ hoofdzakelijk afwijkende, uitstrijkjes herbeoordeeld, waarbij de afname gebeurde met een gecombineerde spatel + Cytobrushtechniek.

Voor beide afnames afzonderlijk werd het voorkomen van afwijkende cellen, van endocervicale of metaplastische cellen en van plaveiselcellen geregistreerd.

Het gebruik van de Cytobrush alleen zou in deze reeks aanleiding gegeven hebben tot $3 \%$ witstrijkjes zonder plaveiselcellen, tot $3 \%$ vals negatieve witstrijkjes en tot $7 \%$ uitstrijkjes waarbij de diagnose, witgedrukt in Pap-klasse, onderschat werd. Daarbij bestaat er een verband tussen de kans op een vals negatief $C$ vtobrushuitstrijkje en de afwezigheid van plaveiselcellen in deze witstrijkjes.

De inhoud van dit hoofdstuk is een bewerking van:

* Buntinx F., Boon M.E., Beck S. Knottnerus d.A., Essed G.G.M. Comparison of Cytobrush sampling, spatula sampling and combined Cytobrush-spatula sampling of the uterine cervix. Acta Cytol 1991; 35: 64-68. 


\section{$\therefore \quad 4: 3: 3$}

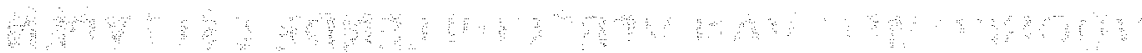

$$
\text { a } 7 \text { : }
$$

B

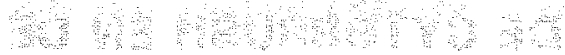

Mal

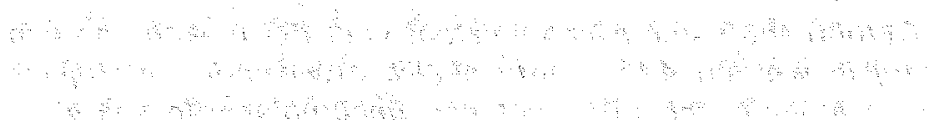

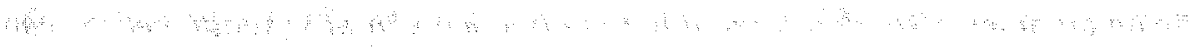

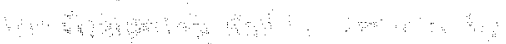

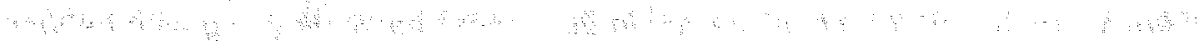

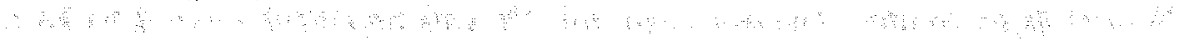

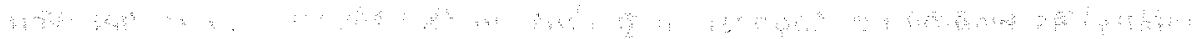

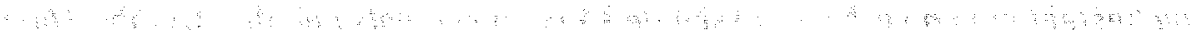

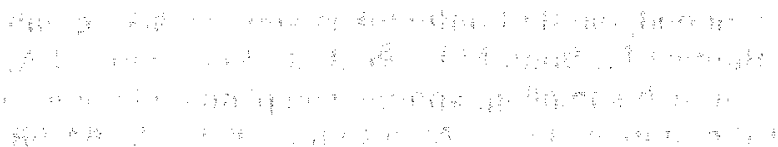




\section{INLEIDING}

In de hoofdstukken 4 en 5 van dit proefschrift rapporteren wil over twee studies bif een groep Vlaamse artsen waarbij ondermeer de gebruikelijke afnamemethode voor cervixuitstrijkjes werd nagegaan.

Ulit deze enquetes is gebleken dat nogal wat artsen bij het afnemen van een cervixuitstrijkje alleen gebruik maken van een Cytobrush als afnameinstrument. Dit doet de vraag rijzen in welke mate daarbij de overgangszone gemist wordt, met name bij vrouwen met een erythroplakie. Hieruit volgt de vraag in weike mate pathologische cellen door deze werkwijze gemist worden; in de literatuur vonden wij geen rechtstreeks antwoord op deze vragen. Daarom onderzochten wij dit door de bestudering van een reeks uitstrijkjes, afkomstig van patienten bij wie zowel een spatelafname als een Cytobrushafiname verricht was.

Onze onderzaeksvragen waren de volgende:

1. Hoeveel procent van de pathologie, gedefinieerd als tenminste lichte dysplasie. respectievelijk tenminste ernstige dysplasie, zou gemist zijn als van deze pati" enten alleen een Cytobrushuitstrijk, respectievelijk een spateluitstrijk gemaakt zou zijn?

2. In welke mate komen in het Cytobrushdeel van de uitstrijkjes niet alleen endocervicale, maar ook ectocervicale cellen voor?

3. Is er een relatie tussen een vals negatieve cytologische uitslag en de afwezigheid van plaveiselcellen, respectievellik endocervicale cellen in het uitstrijkje?

\section{MIETHODE}

In het Leids cytologisch en Pathologisch Laboratorium worden alle afwijkende cervixuitstrijkjes (Pap-klasse lil en hogerl bewaard. Voor de meeste van deze uitstrijkjes is zowel een spatelafname als een Cytobrushafname beschikbaar. De uitstrijkjes zijn zowel afkomstig uit de dagelijke huisartspraktijk als uit het bevolkingsonderzoek.

Voor dit onderzoek werden alle uitstrijkjes van 304 opeenvolgende patiënten opnieuw bekeken van wie de beoordeling van het laatste uitstrijkje tenminste ernstige dysplasie te zien gaf. De volledige reeks omvat 444 ultstrijkjes, waarvan 304 met een oorspronkelijke diagnase "ernstigle dysplasie of meer", 108 met "lichte of matige dysplasie" en 32 oorspronkelijk afgegeven als "normaal".

Voor elk uitstrijkje werden de aanwezige celtypen en de aanwezigheld van pathologische cellen beschreven voor de spatel en de Cytobrushuitstrijken afzonderlijk. Als er pathologische cellen aanwezig waren, werd het uitstrijkje ingedeeld in éen van twee groepen: "lichte of matige dysplasie" of "ernstige dysplasie of meer". De diagnostische beoordeling van elk glaasje werd vergeleken met de beoordeling van de gecombineerde uitstrijk. Deze laatste beoordeling gold als standaard. De aanwezigheid van endocervicale (en/of metaplastische) cellen en plaveiselcellen, werden voor elke afname apart geregistreerd.

De ouderdom van de patiënte, het jaar van de afname van het uitstrijkje en de identificatie van de beoordelaar werden afzonderlijk geregistreerd. 
De uitstrijkjes werden (her-)beoordeeld door 9 screensters, die elk minimaal 16 en maximaal 88 preparaten voor hun rekening namen. Een Kruskall-Wallis analyse toont geen significante verschillen tussen de leeftijdsverdelingen der patiënten van de verschillende screensters.

Het aantal cellen van een bepaald type lendocervicaal, metaplastisch, plaveiselcellen) werd semikwantitatief geregistreerd op een vijfpuntsschaal en daarna gegroepeerd in 2 morfologische klassen: endocervicale cellen (met inbegrip van de metaplastische cellen) en plaveiselcellen.

Zowel voor de aanwezigheid van pathologische cellen als voor de aanwezigheid en het aantal van de beide celtypen, werd het verschil tussen elke afnamemethode en de standaard geanalyseerd. Telkens werd ook de overeenkomst tussen de beide aframetechnieken geëvalueerd met behulp van een Cohen's Kappa. Als er daarbil meer dan twee klassen per waarnemingsmethode waren, werd een gewogen kappa gebruikt.

Betrouwbaarheilds Intervallen werden berekend met behulp van Geigy Scientific Tables (Diem 1978). Chi ${ }^{2}$ testen werden berekend met behulp van een Statgraphics programma (Anoniem 1986). Wanneer de beschikbare getallen te klein waren voor het berekenen van de $\mathrm{Chi}^{2}$-test werd gebruik gemaakt van de Fisher's exact test.

\section{RESULTATEN}

Bij een herbeoordeling van de uitstrijkjes, gebaseerd op de combinatie van beide afnames (dit betekent dat het meest pathologische uitstrijkje als standaard gebruikt wordt), bleken 32 uitstrijkjes als normaal beoordeeld te worden, 108 toonden een lichte tot matige dysplasie en 304 toonden ernstige dysplasie of meer (tabel 10.1).

\section{Pathologische cellen bij Cytobrushuitstrijkjes}

In 400 Cytobrushuitstrijkjes werden pathologische cellen gevonden (tabel 10.1). Ten opzlchte van de combinatie van beide afnametechnieken zou hierdoor dus sprake zijn van 12 vals negatieve uitstrijkjes of $12 / 412=2.9 \%(95 \% \mathrm{BI}=1.5$. 5.1). Het gebruik van beide technieken in combinatie levert ten opzichte van de afname met Cytobrush alleen een relatieve winst in correcte diagnosen van $412 / 400-1=3 \%(95 \% \mathrm{Bl}=1.6-5.2)$.

Er zijn 304 uitstrijkjes waarin bij herevaluatie in tenminste én van beide ulitstrijkjes (opnieuw) cellen gevonden worden, die passen bij een PAP-klasse lllb of hoger (sterke dysplasie of meer).

Als er in deze gevallen alleen een Cytobrushuitstrijk gemaakt was, zou dit aantal slechts 282 geweest zijn. Er zou hierdoor dus sprake zijn van 22 uitstrijkjes, waarbij de diagnose onderschat (18) of gemist $(4)$ zou zijn. Dit is $22 / 304=7.2 \%$ $(95 \% \mathrm{Bl}=4 \cdot 6-10 \cdot 8)$. Bij deze uitstrijkjes levert het gebruik van beide technieken in combinatie ten opzichte van de afname met de Cytobrush alleen een relatieve winst in correcte diagnosen van $304 / 282-1=78 \%(95 \% \mathrm{BI}=4.9-11.7)$. 
Als er alleen een Cytobrushuitstrijk zou gemaakt zijn in de 108 gevallen die als lichte of matige dysplasie afgegeven werden, zou de diagnose gemist zijn in 8 gevallen. Dit betekent dat er in deze groep sprake zou zijn van $8 / 108=7.4 \%$ $195 \% \mathrm{Bl}=3.2-13.91$ vals negatieve resultaten.

Het gebruik van beide technieken in combinatie leverde een winst in correcte diagnosen van $8 / 100=8 \%(95 \% \mathrm{Bl}=3.5-15.2)$.

In totaal zijn er 30 uitstrijkjes waarin de diagnose ofwel gemist (12), ofwel onderschat (18) zou zijn als er alleen een Cytobrushuitstrijkje gemaakt zou zijn. Dit is $30 / 412=7.3 \%(95 \% \mathrm{BI}=4.9-10.3)$.

Het gebruik van beide technieken in combinatie levert ten opzichte van de afname met Cytobrush alleen een relatieve winst in correcte diagnosen van $412 / 382$ - 1 $=7.9 \%(95 \% \mathrm{Bl}=5.0-11.1)$.

Tabel 10.1: Gevonden afwijkingen in de Spatel-, respectlevelijk Cytobrushafnames bij 444 cervixuitstrijkjes

\begin{tabular}{|c|c|c|c|c|}
\hline \multirow{2}{*}{ Spatellame } & \multicolumn{4}{|c|}{ C. Cytobrushafname } \\
\hline & $\begin{array}{c}\text { Normat } \\
\end{array}$ & $\begin{array}{l}\text { Lichte of matige } \\
\text { dysplesie }\end{array}$ & $\begin{array}{c}\text { Eirnstiga dyspla } \\
\text { sie of mor }\end{array}$ & Totan \\
\hline Normal & 32 & 24 & 19 & 75 \\
\hline Lichte/matlige dysplasie & 8 & 76 & 35 & $1: 9$ \\
\hline Errastige dysplasie of meer & $4 \quad$ & 18 & 228 & 250 \\
\hline Total & 44 & 118 & 282 & 444 \\
\hline
\end{tabular}

\section{Pathologische cellen bij afname met de Spatel alleen}

Als er alleen een spateluitstrijk gemaakt was, zou het aantal afwijkende uitstrijkjes slechts 369 zijn. Er zou hierdoor dus sprake zijn van 43 vals negatieve uitstrijkjes of $43 / 412=10.4 \% 195 \% \mathrm{BI}=7.6-13.81$. Het gebruik van beide technieken in combinatie levert ten opzichte van de afname met de spatel alleen een relatieve winst in correcte diagnosen van $412 / 369-1=11.7 \%(95 \% \mathrm{Bl}=8.5-15.61$.

Er zijn 304 uitstrijkjes waarin bij herevaluatie in tenminste eén van beide uitstrijkjes (opnieuw) cellen gevonden worden, compatibel met een PAP-klasse Illb of hoger (ernstige dysplasie of meer).

Als er alleen een spateluitstrijk gemaakt was, zou dit aantal slechts 250 geweest zijn. Er zou hierdoor dus sprake zijn van 54 uitstrijkjes, waarbij de diagnose onderschat (35) of gemist (19) zou zijn. Dit is $54 / 304=17.8 \%(95 \% \mathrm{Bl}=14.1$. 23.21. Bij deze vitstrijkjes levert het gebruik van beide technieken in combinatie ten opzichte van de afname met spatel alleen een relatieve winst in correcte diagnosen $\operatorname{van} 304 / 250-1=21.6 \%(95 \% \mathrm{~B} \mid=15.8-27.6)$.

Als er alleen een spateluitstrijk zou gemaakt zijn in de 108 gevallen met lichte of matige dysplasie, zou dit 24 vals negatieve resultaten tot gevolg gehad hebben of $22.2 \%(95 \% \mathrm{Bl}=14.9-31.1)$. 
Het gebruk van beide technieken in combinatie leverde een winst in correcte diagnosen van $24 / 108=28.6 \%(95 \% \mathrm{BI}=19.2-39.5)$

In totaal zijn er 78 uitstrijkjes waarin de diagnose ofwel gemist $(43)$, ofwel onderschat (35) zou zijn als er alleen een spateluitstrijk gemaakt zou zijn. Dit is $78 / 412=18.9 \%(95 \% \mathrm{BI}=15.3-23.3)$.

Het gebruik van beide technieken in combinatie leverde ten opzichte van de afname met de spatel alleen een relatieve winst in correcte diagnosien van 412 / $334-1=23.3 \%(95 \% \mathrm{Bl}=18.9 .28 .3)$.

\section{Pathologische cellen - Overeenkomst tussen beide afnames}

Op basis van de gegevens van tabel 10.1 is er een vast te stellen overeenkomst (observed agrement) tussen de resultaten van spatelafname en de Cytobrushafname van $336 / 444=74 \%$.

Deor toeval alleen kan men een overeenkomst lagreement expected on the basis of chancel verwachten van $199,6 / 440=45 \%$.

Er is dus maximaal een extra overeenkomst boven het kanspercentage (potential agreement beyond chancel magelijk van $100-45=55 \%$.

De berekende extra overeenkomst boven het kanspercentage lactual agreement beyond chance) is $74-45=29 \%$.

De Kappa bedraagt $29 \% / 55 \%=0.53$.

Wij berekenden een gewogen kappa als maat woor de Inter-observer overeenkomst tussen de beide afnametechnieken. Daarbij gaven wij een gewicht van 1 aan de aantallen op de diagonaal (tabel 10.1). De aangrenzende aantallen kregen een gewicht van $1 / 4$. Wij berekenden zo een vast te stellen overeenkomst lobserved agreement) tussen de resultaten van spatelafname en de Cytobrushafname van $357 / 444=80 \%$.

Door toeval alleen kan men een overeenkomst lagreement expected on the basis of chancel verwachten van $241 / 440=54 \%$.

Er is dus maximaal een extra overeenkomst boven het kanspercentage (potential agreement beyond chancel mogelijk vary $100-54=46 \%$,

De berekende extra overeenkomst boven het kanspercentage lactual agreement beyond chance) is $80.54=26 \%$.

De Gewogen Kappa bedraagt $26 \% / 46 \%=0.57$.

\section{Aanwezigheid van plaveiselcellen}

In 94\% van de uitstrijkjes worden plaveiselcillen zowel in de spateluitstrijk als in de Cytobrushuitstrijk gevonden (tabel $10.2 \%$ : In $3.2 \%$ worden de plaveiselcellen alleen in de spateluitstrijk gevonden.

Er wordt een overeenkomst gevonden tussen de resultaten van de spatelafname en de Cytobrushafname van $429 / 444=96.6 \%$.

Door kans alleen kan men een overeenkomst verwachten van $91.2 \%$. Er is dus maximaal een extra overeenkomst boven het kanspercentage mogelijk van 100 - 
$91.2=8.8 \%$. De berekende extra overeenkomst boven het kanspercentage is $96.6-91.2=5.4 \%$. De Kappa bedraagt $5.4 \% / 8.8 \%=0.61$.

Tabel 10.2: Aanwezigheild van plaveiselcellen in Spatel en Cy tobrushuitstrijkjes

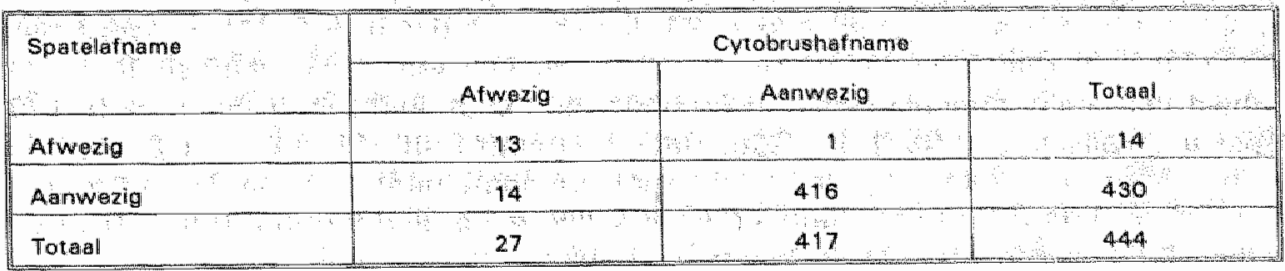

kappa $=0.61$

\section{Aanwezigheid van endocervicale cellen}

In $83 \%$ van de uitstrijkjes worden endocervicale cellen zowel in de spateluitstrijk als in de Cytobrushuitstrijk gevonden (tabel 10.3). In $12 \%$ worden de endocervi. cale cellen alleen in de Cytobrushuitstrijk gevonden.

Tabel 10.3: Aanwezigheid van endocervicale cellen in Spatell-en Cytobrushuitstrijkjes

\begin{tabular}{|c|c|c|c|}
\hline \multirow[t]{2}{*}{ Spatelaf narme } & \multicolumn{3}{|c|}{ Cytobrushaf frame } \\
\hline & Alwazig & Aanwezig & Tot arat \\
\hline Afwerig & 18 & 54 & 72 \\
\hline Aanwezig & 3 & 369 & 372 \\
\hline Totaal & $21 \%$ & 423 & 4.44 \\
\hline
\end{tabular}

kappo: $=0.34$

Er is een overeenkomst tussen de resultaten van de spatelafname en de Cytobrushafname van $387 / 444=87.2 \%$.

Door toeval alleen kan men een overeenkomst verwachten van $80.6 \%$. Er is dus maximaal een extra overeenkomst boven het kanspercentage mogelijk van 100 . $80.6=19.4 \%$. De berekende extra overeenkomst boven het kanspercentage is $87.2-80.6=6.6 \%$.

De Kappa bedraagt $6.6 \% / 19.4 \%=0.34$. 


\section{Verband tussen de aanwezigheid van plaveiselcellen, respectieve- lijk endocervicale cellen en vals negatieve uitstrijkjes}

Er kon geen verband aangetoond worden tussen het voorkomen van vals negatieve spateluitstrijkjes, waarbij het totaalresultaat op basis van de beide afnames als standaard gebruikt wordt, en het al dan niet vinden van plaveiselcellen in het betrokken spateluitstrijkje (Fishers Exact $p=0.24$ Kruskal- Wallis $p=0.21$ ). Er werd wel een duidelijk verband gevonden tussen vals negatieve spateluitstrijken en de afwezigheid van endocervicale cellen in de betrokken spateluitstrijk (Chi ${ }^{2} p=0.005$ Kruskal - Wallis $p=0,002)$. De Odds Ratio bedraagt $2.85(95 \% \mathrm{Bl}=1.23-6.02)$. Dit betekent dat de kans op een vals negatieve spateluitstrijk bijna $3 \times$ zo hoog is als er in het uitstrijkje geen endocervicale cellen gevonden worden (tabel 10.4 ).

Tabel 10.4: Relatie tussen de afwezigheid van endocervicale cellen/plaveiselcellen in Spatel/Cytobrushuitstrijkjes enerzijds en vals negatieve resultaten anderzijds

\begin{tabular}{|c|c|c|c|c|c|c|}
\hline \multirow{3}{*}{$\because \quad \vdots \quad \vdots$} & \multicolumn{3}{|c|}{ Spatelafriamo } & \multicolumn{3}{|c|}{ Cytobrushafname } \\
\hline & \multicolumn{3}{|c|}{ Endocervicalecellem } & \multicolumn{3}{|c|}{ Plaveiseledien } \\
\hline & Alwezig & Aanwezig & Totanal & Alwezig & Aanwezig & Totas \\
\hline Valsnegatief & 14 & 29 & 43 & 3 & 9 & 12 \\
\hline Aincere & 58 & 343 & 401 & 24 & 408 & 432 \\
\hline Total & 72 & 372 & 444 & 27 & 417 & 444 \\
\hline
\end{tabular}

$p=0.005\left(\mathrm{Ch}_{\mathrm{i}} \mathrm{i}^{2}\right)$

odds ratio $=2.85$ $p=0,003$ \{Fisher:s Exact odds ratio $=5.67$

Omgekeerd kon geen verband aangetoond worden tussen vals negatieve Cytobrushuitstrijken en de afwezigheid van endocervicalle cellen in de betrokken Cytobrushuitstrijk. (Fisher"s Exact $p=0.45$ Kruskall - Wallis $p=0.55$ )

Er werd daarentegen wel een duidelijk verband aangetoond tussen vals negatieve Cytobrushuitstrijken en de afwezigheid van plaveiselcellen in de betrokken Cytobrushuitstrijk. (Fisher's Exact $p=0.003$ Kruskall - Wallis $p=0.005$ ). De Odds Ratio bedraagt hier $5.67(95 \% \mathrm{BI}=1.18-25.08)$. Dit betekent dat de kans op een vals negatieve Cytobrushuitstrijk meer dan $5 \times$ hoger is als er in het uitstrijkje geen plaveiselcellen gevonden worden.

\section{DISCUSSIE}

Dit onderzoek evalueerde de mogelijke invloed van een afname met de Cytobrush alleen op de resultaten van cervixuitstrijkjes. Onze onderzoeksmethode richtte zich daarbij op die uitstrijkjes waarvoor dit de belangrijkste consequenties kan hebben. met name afwijkende uitstrijken. 
Alle opeenvolgende uitstrijkjes met een diagnose ernstige dysplasie of meer gedurende de onderzoeksperiode, werden in onze registratie opgenomen. Deze uitstrijkjes zijn zowel afkomstig uit het bevolkingsonderzoek als uit de dagelijkse praktijkvoering van artsen. Er zijn geen aanwijzingen dat hierbij een opvallende selectie is opgetreden. De uitstrijkjes die oorspronkelijk als lichte dysplasie of minder beoordeeld waren, zijn echter in hoge mate geselecteerd: uiteindelijk hebben al deze patiënten later een ernstige dysplasie of meer vertoond. Hierdoor kunnen deze resultaten niet zonder meer veralgemeend worden naar de totale groep van routinegewijs afgenomen cervixuitstrijkjes.

Bij de door ons gebruikte onderzoekssetting is vertekening mogelijk bij de afname en bij het aflezen van de uitstrijkjes: terwijl bij een Cytobrushafname de uitstrijkende arts wist dat hij tegelijkertijd ook een spatelafname zou doen is het denkbaar dat hij de Cytobrushafname zorgvuldiger of zelfs anders zou doen als dit zijn enige afname was. Uiteraard is deze redenering ook toepasbaar op de spateluitstrijk.

Daarbij is de volgorde van de twee afnames niet gestandaardiseerd. Er zijn argumenten om te verwachten dat een eerste afname steeds meer pathologie geeft dan een meteen erna uitgevoerde tweede afname.

Omdat beide uitstrijkjes zich op eenzelfde glaasje bevonden, en omdat de beoordelaars wel wisten dat de meeste van deze uitstrijkjes vroeger ais afwijkend geclassificeerd geweest waren, is het mogelijk dat er enige mate van correlatie opgetreden is tussen de beoordeling van de twee afnames.

$\mathrm{Er}$ is geen reden om aan te nemen dat deze vertekeningen, indien zij inderdaad opgetreden zouden zijn, onze resultaten op systematische wijze zouden beïnvloeden. Een eventuele niet systematische vertekening zou een onderschatting van onze resultaten tot gevolg hebben. In latere, prospectieve studies kan met deze mogelijke vertekeningen rekening gehouden worden. Voorlopig hebben wij echter geen argumenten om te twijfelen aan onze belangrijkste bevindingen.

Zoals we reeds gevreesd hadden, blijkt dat het maken van uitstrijkjes met de Cytobrush alleen aanleiding geeft tot het onderschatten van de diagnose in $7.3 \%$ van de gevallen $(95 \% \mathrm{Bl}=4.9-10.3)$. In $4.4 \%$ van de gevallen $(95 \% \mathrm{Bl}=2.7$. $7.0)$ wordt op deze wijze een uitstrijkje, dat met de gecombineerde afnamemethode als ernstig dysplasie of meer beoordeeld was, nu met de Cytobrush slechts als matige dysplasie geclassificeerd. Deze patiënten zouden waarschijnlijk toch worden uitgenodigd voor een controle-uitstrijkje of voor een colposcopisch onder. zoek. In $2.9 \%$ van de gevallen van ernstige dysplasie $(95 \% \mathrm{BI}=1.5 .5 .1)$ daarentegen zouden deze patiënten met een Cytobrushuitstrijkje alleen als normaal geklasseerd worden. Wanneer deze patiënten geen specifieke klachten vertonen, zouden ze waarschijnlijk niet gecontroleerd worden en het is mogelijk dat een correcte diagnose met verschillende jaren vertraagd wordt.

Plaveiselcellen waren afwezig in zowat $3 \%$ van de Cytobrushuitstrijkjes, en endocervicale cellen waren afwezig in $12 \%$ van de Spateluitstrijkjes. Dit kan beide geïnterpreteerd worden als een teken dat de overgangszone bij het uitstrijken niet geraakt werd. Wij vonden in deze studie dan ook een opvallende associatie tussen het voorkomen van vals negatieve Cytobrushuitstrijkjes en de afwezigheid van plaveiselcellen in deze uitstrijkjes. 
Wij concluderen dat het gebruik van de Cytobrush alleen voor het maken van een cervixuitstrijkje aanleiding kan geven tot uitstrijkjes zonder plaveiselcellen ( $3 \%$ ). en tot het missen van pathologische cellen $(3 \%)$. Er bestaat daarbij een verband tussen de vals negatieve Cytobrushuitstrijkjes en de afwezigheid van plaveiselcellen in het betrokken Cytobrushuitstrijkje ( $x 6$ ). Deze procedure (Cytobrush alleen) is dus zeker niet aan te raden.

Het lijkt waarschijnlijk dat dit vooral geldt bij vrouwen met een (grote?) erythroplakie. Deze laatste hypothese dient echter getoetst te worden in een prospectieve studie.

De bevindingen van deze studie illustreren eens te meer hoe een verbetering van de techniek een averechts effect kan sorteren wanneer zij door de gebruikers niet volledig begrepen is. De Cytobrush is ingevoerd ter aanvulling en niet ter vervanging van de Spatel. Wanneer een Cytobrush alléen gebruikt wordt; is dit in tegenspraak met de oorspronkelijke bedoeling. Het is van groot belang dat producenten en verdelers van medische apparaten zorg dragen voor een zeer preciese en complete informatie van de artsen over het doel en het gebruik van hun materiaal. 


\section{HOOFDSTUK 11}

\section{VERBAND TUSSEN ERYTHROPLAKIE EN DE AANWEZIGHEID VAN VERSCHILLENDE CELTYPEN IN EEN CERVIXUITSTRIJKJE}

Door middel van een prospectief onderzoek werd nagegaan of de aanwezigheid en de grootte van een erythroplakie invloed hebben op het al dan niet voorkomen van plaveiselcellen in cervixuitstrijkjes. Er werd geen verband gevonden tussen de aanwezigheid van een erythroplakie en de kans dat er geen plaveiselcellen gevonden worden in uitstrijkjes gemaakt met wattenstok of spatel. Ook de grootte van een eventuele erythroplakie lijkt daarbij geen rol te spelen. 
B. " 40 Pas

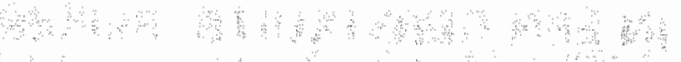

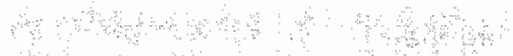
Q

Hest

(3)

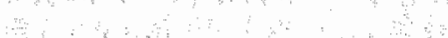




\section{INLEIDING}

In hoofdstuk 10 hebben we gerapporteerd over een onderzoek waarbij werd geconcludeerd dat het afnemen van een cervixuitstrijkje met alleen een endocervicale afnamemethode (Cytobrush) aanleiding kan geven tot vals negatieve uitstrijkjes. Een dergelijk verband is ook gesuggereerd door Spurret e.a. (Spurret e.a., 1989). In onze studie vonden wij ook een positieve relatie tussen de afwezigheid van plaveiselcellen in het Cytobrushuitstrijkje en de kans op een vals negatief resultaat. In hoofdstuk 4 bleek al dat dit niet alleen van academisch belang is, aangezien $16 \%$ van een groep Belgische huisartsen die allen met één groot laboratorium samenwerken, verklaarden bij het maken van cervixuitstrijkjes alleen een Cytobrushafname te gebruiken.

In de discussieparagraaf bij hoofdstuk 10 hebben we de hypothese geformuleerd dat de risico's die verbonden zijn aan het maken van uitstrijkjes met alleen een endocervicale afname het meest uitgesproken zouden zijn bij patiënten met een erythroplakie van de cervix.

In dit onderzoek wordt nagegaan in welke mate de aanwezigheid van een erythroplakie invloed uitoefent op de kans dat plaveiselcellen ontbreken in uitstrijkjes, gemaakt met alleen een endocervicale afnametechniek.

\section{METHODE}

Deze studie betreft 458 opeenvolgende cervixuitstrijkjes, gemaakt door drie stafleden van de gynaecologische polikliniek van het Academisch Ziekenhuis te Maastricht. Voor iedere patiënt maakten zij een dubbel uitstrijkje. Daarbij werd eerst de wattenstok gebruikt en daarna de spatel met het verlengde uiteinde (extended-tip). De leeftijd van de patiënt, de aanwezigheid en de geschatte diameter van een eventueel voorkomende erythroplakie van de cervix werden op een standaardformulier geregistreerd Voor ieder uitstrijkje afzonderlijk werd door de afdeling Cytologie van het Academisch Ziekenhuis de aanwezigheid van plaveiselcellen, van endocervicale cellen en van pathologie genoteerd.

Wij correleerden per patiënte de aanwezigheid en de diameter van een eventueel voorkomende erythroplakie met de aanwezigheid van plaveiselcellen en endocervicale cellen in elk van de beide uitstrijkjes. De statistische significantie van eventuele relaties werd getoetst met een $\mathrm{Chi}^{2}$-, respectievelijk een Fisher's Exacttest voor de aanwezigheid en met een $\mathrm{Chi}^{2}$ for trend-test voor de diameter van een eventuele erythroplakie. Een Mac Nemar-test voor gepaarde waarnemingen werd gebruikt als toets voor de statistische significantie van eventuele verbanden tussen de aanwezigheid van de beide onderzochte celtypen en de gebruikte afnametechniek.

\section{RESULTATEN}

De invloed van de afnamemethode op de aanwezigheid van zowel endocervicale als plaveiselcellen is opvallend. 
Tabel 11.1: Aanwezigheid wan endocervicale, respectievelijk plaveiselcellen in de spatel-(kolommen), respectievelijk de wattenstokuitstrijk (rijen) in relatie tot de afnamemethode

\begin{tabular}{|c|c|c|c|c|c|c|}
\hline & \multicolumn{3}{|c|}{ Erndocervicale calten } & \multicolumn{3}{|c|}{ Plavenselcullen } \\
\hline Spatcl & 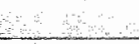 & 8 & & tenstok & & \\
\hline अ४ं। & Aanwerig & Afwezg & Tora & Aanwerig & Afwezig & Total \\
\hline Aanweatg & 261 & 175 & $\quad 436$ & 425 & 27 & 452 \\
\hline Afwezig & 5 & 16 & 20 & $a$ & 5 & 5 \\
\hline Totad & 266 & 190 & $460^{\circ}$ & 425 & 32 & 467 \\
\hline
\end{tabular}

Mc Nomar: $\mathrm{p}<0.001$

Mc Nemax: $p<0.001$

Bij patiênten met een erythroplakie werden geen plaveiselcellen gevonden in $5 \%$ van alle wattenstokuitstrijkjes. Bij patienten zonder erythroplakie zijn ze in $9 \%$ afwezig.

In Spateluitstrijkjes werden slechts 6 op 458 uitstrijkjes zonder plaveiselcellen gevonden. Zij zijn alle afkomstig van patiënten zonder erythroplakie.

Geen van deze verschillen is statistisch significant.

Tabel 11.2: Aanwezigheild van plaveiselcellen in cervixuitstrijkjes, gemaakt bij patientein met, respectievellijk zonder ery throplakie

\begin{tabular}{|c|c|c|c|c|c|c|}
\hline & \multicolumn{3}{|c|}{ Wattenstokuits stijkje } & \multicolumn{3}{|c|}{ Spateluitstrijkje } \\
\hline $\begin{array}{l}\text { Plavieliselcell. } \\
\text { lon }\end{array}$ & $\begin{array}{l}\text { Mor erythro- } \\
\text { plakia }\end{array}$ & $\begin{array}{c}\text { Zonder ery: } \\
\text { throplekie }\end{array}$ & Totaial & $\begin{array}{l}\text { Met arythro } \\
\text { plakie }\end{array}$ & $\begin{array}{c}\text { 2ander ery- } \\
\text { throplakie }\end{array}$ & Total \\
\hline Aanweztig : & $\quad 165$ & 260 & 426 & 173 & 279 & 452 \\
\hline Afwezg & $\theta$ & 25 & 33 & 0 & $\therefore$ & $\therefore 6$ \\
\hline Toteal & 173 & 285 & 458 & 173 & 285 & 458 \\
\hline
\end{tabular}

$p=0.4\left(\mathrm{Ch}^{2}\right)$

$p=0.09$ fisher' Exact)

In een tweede fase stelden wij tabel 11.2 opnieuw samen, waarbij we de patiënten met een erythroplakie onderverdeelden in twee groepen volgens de diameter van de erythroplakie: meer of minder dan $1 \mathrm{~cm}$. Voor 8 patienten beschikten wij niet over de grootte van de erythroplakie. Wij vonden geen significant verband tussen een erythroplakie van meer dan $1 \mathrm{~cm}$ en de aanwezigheid ${ }$ respectievelijk afwezigheid van plaveiselcellen. Er werd zelfs helemaal geen trend in deze zin gevonden. 
Tabel 11.3. Aamwezighelid van plaveiselcellen in Wattenstolk-uitstrijkjes in relatie tot de diameter van een eventuele erythroplakie

\begin{tabular}{|c|c|c|c|c|}
\hline \multirow[t]{2}{*}{ Plaveiselcellen } & \multicolumn{4}{|c|}{ Erythroplakid } \\
\hline & $\geq 1 \mathrm{~cm}$ & $<1 \mathrm{~cm}$ & gem & totaal \\
\hline Aanwezig & 96 & 60 & $26 \pi$ & 417 \\
\hline Afwerig & 5 & 3 & 25 & 33 \\
\hline Toteal & 101 & 63 & 286 & 450 \\
\hline
\end{tabular}

$p=0.32\left(\right.$ Chi $^{2} y$

$\mathrm{p}=0.16$ (Chi $^{2}$ for trend!

In spateluitstrijkjes vonden we geen endocervicale cellen terug in slechts 22 op 458 uitstrijkjes. In wattenstokuitstrijkjes daarentegen waren er $192 / 458$ of $42 \%$ van de uitstrijkjes zonder endocervicale cellen. Er is geen statistisch significant verschil tussen de uitstrijkjes van patiënten met $(44 \%)$ versus zonder $(38 \%)$ erythroplakie. $p=0.37\left(\mathrm{Chi}^{2}\right)$.

\section{DISCUSSIE}

In ons onderzoek wilden wij de invloed nagaan van een erythroplakie op de aanwezigheid van plaveiselcellen in een endocervicaal afgenomen cervixuitstrijkje. Hiervoor gebruikten wij uitstrijkjes die afgenomen waren met een wattenstok. Het is niet zeker dat onze resultaten dezelfde zouden zijn als in plaats van een wattenstok een Cytobrush gebruikt was. Omdat in beide afnametechnieken dezelfde delen van de baarmoeder geraakt worden, is het echter wel waarschijnlijk. Kawaguchi e.a. vergeleken de percentages cervixuitstrijkjes zonder plaveiselcellen; gemaakt met een Cytobrusin alleen, met die gemaakt met een wattenstok alleen. Zij vonden geen statistisch significant verschil. (Kawaguchi e.a. 1987)

in de literatuur ( Doornewaard e.a. 1990, Kawaguchi e.a. 1987, Willockx e.a. 1989) vonden wij percentages van Cytobrush-alleen uitstrijkjes zonder plaveiselcellen tussen 0.4 en $23.6 \%$. Wat betreft de afnames met wattenstok alleen beschikken wij slechts over de studie van Kawaguchi e.a. (Kawaguchi e.a. 1987). Zij rapporteren $1 \%$ uitstrijkjes zonder plaveiselcellen.

In dit onderzoek kon geen relatie aangetoond worden tussen de aanwezigheid of de grootte van een erythroplakie en de kans op een Wattenstokuitstrijk zonder plaveiselcellen.

Op basis van deze gegevens zijn wij niet in staat een redelijke verklaring aan te bieden voor onze vroegere bevindingen en die van anderen waaruit blijkt dat endocervicaal afgenomen uitstrijkjes een relatief hoge kans geven op afwezigheid van plaveiselcellen. Deze waarneming blifft echter van belang en wordt zelfs bevestigd door de gegevens van dit onderzoek (tabel 11.2). Wij blijven dan ook bij onze aanbeveling dat het maken van uitstrijkjes met alleen een endocervicale afnametechniek, hetzij met een Cytobrush hetzij met een wattenstok, geen goede 
methode is voor de produktie van cervixuitstrijkjes van goede kwallteit. Daarenboven blijkt het ook niet mogelijk op basis van het makroskopisch beeld aen groep patienten af te grenzen waarvoor dit wel het geval zou zijn. 


\section{SAMENVATTING}

In het kader van de onderzoekslijn: waarover in dit proefschrift gerapporteerd wordt, werd een systematisch literatuuronderzoek verricht naar verbanden tussen kwaliteitskenmerken van cervixuitstrijkjes en het vinden van pathologie en haar het belang van allerlei factoren op deze afnamekwaliteit (hoofdstuk 1 en 2). Daarbij werd gebruik gemaakt van analysetechnieken die de laatste jaren onder de naam meta-analyse steeds meer ingang vinden in de medische literatuur. De hierbij gebruikte methoden werden uitvoerig beschreven in een methodologische kanttekening (hoofdstuk 3).

Duidelijk is dat uitstrijkjes ofwel metaplastische cellen, ofwel een combinatie van endocervicale en plaveiselcellen dienen te bevatten opdat aangenomen kan worden dat de overgangszone tenminste geraakt werd. Men is echter nooit zeker dat deze overgangszone volledig uitgestreken werd. Uit ons literatuuronderzoek blijkt de combinatie van spatel + Cytobrush de beste afnametechniek voor het maken van cervixuitstrijkjes. Fixatie dient meteen na het uitstrijken te gebeuren, liefst met een speciaal daartoe bereide spray. Er bestaat een belangrijke inter-uitstrijk(st)er variatie in de bereikte afnamekwaliteit, ook al lijkt die te stijgen met de ervaring van de uitstrijk(st)er. Er lijkt geen relatie te bestaan met de discipline van de uitstrijk(st)er. De belangrijke verschillen die gevonden werden tussen landen en regio's, ook na correctie voor de gebruikte afnametechniek, zijn opvallend.

Het veldonderzoek startte met een schriftelijke enquête naar afnamegewoonten en -ervaringen bij het maken van cervixuitstrijkjes, toegestuurd aan alle artsen die samenwerken met het Centraal Laboratorium in Antwerpen (hoofdstuk 4). Er bleek een grote diversiteit van afnametechnieken gebruikt te worden, waarbij de combinatie van spatel + Cytobrush het meest populair was. Opvallend en verontrustend was daarbij echter de vaststelling dat $16 \%$ van de betrokkenen aangaf de Cytobrush alleen te gebruiken.

Een beschrijvend onderzoek naar de afnamekwallteit van ruim 4000 uitstrijkjes (hoofdstuk 5) en naar het verband van de afnamekwaliteit met de gebrukte afnametechniek en met een aantal kenmerken van de vitstrijkende arts, toonde een afwezigheid van endocervicale cellen in $20 \%$ en onvoldoende fixatie in $2 \%$ van de uitstrijkjes. Een slechte kwaliteit voor de criteria celhoopjes, tekenen van ontsteking en celrijkdom werd slechts in minder dan $1 \%$ van de uitstrijkjes gevonden. Er bleek een sterk verband tussen de aanwezigheid van endocervicale cellen en het gebruikte afnamemateriaal, waarbij de Cytobrush voor dit item het best scoorde. Vrouwelijke artsen bleken niet alleen meer uitstrijkjes te maken dan hun mannelijke collega's, maar ook een hoger percentage afwijkingen te vinden. Uiteraard bleken gynaecologen meer afwijkende uitstrijkjes te maken dan huisartsen. Voor een deel is dit wellicht te wijten aan controles van verwezen patiënten. Het percentage 
afwijkende uitstrijkjes bleek overigens het hoogst bij artsen die tussen 50 en 100 uitstrijkjes per jaar maken. Onder en boven deze grenzen neemt dit percentage af.

In en logistische regressie-analyse met betrekking tot ruim 17.000 uitstrijkes werd het verband bestudeerd tussen de score per uitstrijkje voor 5 kwaliteitsindicatoren en de aanwezigheid van cytologische afwiljingen thoofdstuk 6). Daarbij werd gecontroleerd voor de leeftijd van de patienten en voor de persoion van de screenende laboratoriumassistente. Voor zover ons bekend werd nooit eerder thet verband tussen kwaliteit en pathologie op een dergelijke schaal nagegaan met controle voor zoveel kwaliteitskenmerken en co-variabelen. Zoals verwacht; vonden wij een duidelijke invloed van de leeftijd en (niet significant) van de aanwezigheid van endocervicale cellen op de kans op cytologische afwijkingen. Een verrassing was echter de bevinding dat een onvoldoende fixatie gepaard gaat met een zevenvoudige stijging van het aantal afwijkende uitstrijkjes. De hypothese dat onvoldoende fixatie aan de basis kan liggen van een aantal vals positieve bevindingen, dringt zich daarbif op.

Tevens werd nagegaan in hoeverre de kwaliteitsbeoordelingen van de 4 verschillende laboratoriumassistenten, die voor de screening van de uitstrijkjes instonden, met elkaar overeenstemmen (hoofdstuk 7 .

Het percentage overeenkomst in de beoordeling van het voorkomen van endocervicalle cellen, na correctie voor de overeenkomst die door toeval reeds te verwachten is (kappal, ligt na groepering en dichotomisatie op $0.56195 \% \mathrm{Bl}=0.49-0.63$ ) wat als heel behoorlijk kan worden beschouwd. De niet voor toeval gecorrigeerde overeenkomst voor de andere indicatoren schommelt tussen 86-100. Het bepalen van een kappa-waarde is daarbij vrijwel onmogelijk vanwege het lage aantal uitstrijkjes dat voor deze indicatoren een slechte beoordeling krijgt fvoor individuele laboranten is dit vaak null.

Het belangrijkste onderdeel van ons onderzoek was een gecontroleerde en gerandomiseerde interventiestudie bij 179 Vlaamse artsen naar het effect van drie methoden van feedback met toenemende intensiteit op de afnamekwaliteit van de door deze artsen vervaardigde cervixuitstrijkjes (hoofdstuk 81. Na een basislifnperiode van drie maanden werden de artsen gerandomiseerd in een controlegroep (groep $A$ ) en drie interventiegroepen (groep $B, C, D$ ). In de drie interventhegroepen werd daarna aan het gebruilkelijke uitslagformulier van het uitstrijkje een kwaliteitsbeoordeling van het betrokken uitstrijkje toegevoegd. De artsen uit de groepen $C$ en $D$ kregen daarenboven maandelijks een overzicht toegestuurd van de gledetailleerde $k$ waliteitsbeoordelingen van de voorbije maand. Daarbij werd het resultalat van elke individuele arts vergeleken met het gemiddelde van alle ontvangen uitstrijkjes. De artsen van groep D ontvingen daarenboven, wanneer daartoe aanleiding bestond, gericht advies voor verbetering van de afnamekwaliteit van de door hen vervaardigde uitstrijkjes.

Regressieanalyse toonde een significante daling van het veranderingsquotiënt voor afwezigheid van endocervicale cellen in de twee groepen, waarin gebruik gemaakt werd van maandelijkse kwaliteitsoverzichten en vergelijking met de resultaten van de andere artsen, tot $75 \%$ van de waarden in de twee andere groepen. Voor de 
artsen die tijdens de onderzoeksperiode meer dan 50 uitstrijkjes instuurden, is er een duidelijke toename van het gemiddelde percentage uitstrijkjes met endocervicale cellen per arts en van het gemiddelde percentage met een algemeen kwallteitsoordeel "goed" per arts bil toenemende intensiteit van de interventie. Er was geen effect op de andere kwaliteitsindicatoren.

Wellicht leidt feedback in de groepen waarin gebruik gemaakt werd van maandelijkse overzichten en vergelijkingen met de resultaten wan de andere artsen, hoofdzakelijk tot verbetering van de afnamekwaliteit (met name voor de indicator aanwezigheid van endocervocale en/of metaplastische cellen) wanneer de betrokken arts voldoende uitstrijkjes maakt om deze feedback ten volle tot zijn recht te laten komen.

Een concreet gevolg hievvan is dat voor het geheel van alle tijdens de onderzoeksperiode vervaardigde uitstrijkjes een halvering gevonden werd van het percentage uitstrijkjes zonder endocervicale cellen en van het percentage uitstrijkjes met een algemeen kwaliteitsoordeel "slecht" in de twee interventiegroepen waarin gebruik gemaakt werd van maandelijkse kwaliteitsoverzichten en vergelijking met de resultaten wan de andere artsen.

Voor het geheel van alle artsen werd een niet significant, maar systematisch toenemend effect gevonden op het percentage uitstrijkjes met afwijkende cellen per arts.

Zonder dat hier gericht naartoe gewerkt werd, blijkt uit een telefonische enquête (hoofdstuk 9) dat het aantal artsen, dat voor het afnemein van cervixuitstrijkjes gebruik maakt van een kwalitatief goede afnametechniek, tijdens de onderzoeksperiode verdubbeld is. Wij vermoeden dan ook dat het effect vam onze interventie gedurende enige tijd nog verder zal toenemen. Deze hypothese zal tijdens een vervolgstudie, die reeds gestart is, getoetst worden.

Onze interventie kost weinig en is weinig arbeidsintensief. Uit de antwoorden op een schriftelijke enquête na het afsiuiten van de onderzoeksperiode, blijkt dat de betrokken artsen feedback, op de wijze zoals door ons uitgevoerd, op prijs stellen. Het lijkt ons dan ook dat alle voorwaarden vervuld zijn om de door ons gebruikte of een vergelijkbare werkwijze op grotere schaal, zij het zorgvuldig gecontroleerd, te gaan toepassen.

Het hoge percentage artsen dat, volgens de bij aanvang vam ons onderzoek uitgevoerde enquête, de Cytobrush als enig afname-instrument glebruikte voor het vervaardigen van cervixuitstrijkjes, verontrustte ons. Wij vreesden dat op deze wijze een grote kans bestond op het missen van de overgangszone, met name bij vrouwen met een erythroplakie. Om deze hypothese te toetsen werden, in samenwerking met het Leids Cytologisch en Pathologisch Laboratorium 444, hoofzakelijk afwijkende uitstrijkjes herbeoordeeld, waarbij de atname gebeurde met een gecombineerde spatel + Cytobrushtechniek thoofdstuk 10\%. Voor beide afnames afzonderlijk werd het voorkomen van afwijkende cellem, van endocervicale of metaplastische cellen en van plaveiselcellen, geregistreerd.

Het gebruik van de Cytobrush alleen zou in deze reeks aanleiding gegeven hebben tot 3\% uitstrijkjes zonder plaveiselcellen, tot $3 \%$ vals negatieve uitstrijkjes en tot $7 \%$ ulitstrijkjes waarbij de diagnose onderschat werd. Daarbij bestond er een 
verband tussen de kans op een vals negatief Cytobrushuitstrijkje en de afwezigheid van plaveiselcellen in deze uitstrijkjes.

De bevestiging van onze vermoedens brengt ons tot het advies dat de afname van cervixuitstrijkjes met de Cytobrush alleen een slechte methode is, die zo snel mogelijk verlatien dient te worden.

Onze hypothese dat dit mogelijk vooral belang heeft voon vrouwen met een erythroplakie, werd getoetst middels een prospectief vergelijkend onderzoek van de uitstrijkjes van vrouwen met en zonder erythroplakie (hoofdstuk 111. Op basis van onze gegevens kon een dergelijk verband niet aangetoond worden. Ook de grootte van een bestaande erythroplakie lijkt geen rol te spelen. 


\section{SUMMARY}

In the context of the line of investigation which is reported in this thesis, an extensive literature study was undertaken concerning, first, the relationships between quality characteristics of cervical smears and the retrieval of pathology. and second; the importance of various factors for this sampling quality lchapters 1 and 2). Recourse was taken to analytic techniques that have found increasing acceptance in medicall literature in recent years under the heading meta-anallysis. The methods employed were described in detail in a methodological annotation (chapter 3 ).

It is clear that cervical smears must contain either meta-plastic cells or a combination of endocervical and squamous cells in order to render it plausible that the transformation zone was at least grazed. Even then however, one may never be certain that this zone was sampled entirely. From our study, it is apparent that the combined spatula + Cytobrush technique is the most adequate for preparing cervical smears. Fixation must take place immediately after smearing, preferrably with a spray specially developed for that purpose. A considerable inter-sampler variation occurs in the obtained sampling quality, although this appears to increase with the experience of the sampler. No relationship seems to exist with the profession of the sampler. The variations in sampling quality found for different countries and regions are remarkable, even when the results are corrected for the sampling technique emplayed.

The field study started off with a written inquiry among all physicians cooperating with the Central Laboratory of Antwerp, concerning sampling methods and experiences in the preparation of cervical smears (chapter 4). It was found that a wide range of sampling techniques were emploved, the combined Spatula + Cytobrush method being the most popular. A striking and alarming observation, however, was that $16 \%$ of the inter-viewees declared using the Cytobrush only.

A descriptive study of the sampling quality of more than 4000 cervical smears (chapter 5) whereby the relationship was in-vestigated between the sampling quality on the one hand and the employed sampling technique as well as a number of characteristics of the sampler on the other, showed an absence of endocervical cells in $20 \%$ and inadequate fixation of $2 \%$ of the smears. Concerning the other criteria for satisfactory sampling quality of cervical smears (sufficient number of cells, absence of signs of inflammation, and lack of clumps of cells) less than one percent of the smears were considered inadequate. A strong relationship was found between the presence of endocervical cells and the employed sampling technique, for which item the Cytobrush scored best.

Female doctors turned out not only to prepare more smears than their male colleagues, but they also obtained a higher percentage of abnormal smears. 
Gynaecologists naturally obtained more pathological smears than general practitioners: In part, this finding appears attributable to the assessment of referred patients. Incidentally, the percentage of abnormal smears obtained was highest among doctors taking between 50 and a 100 smears anually. Both below and above this range the abnormal smear fraction decreases.

In an extensive logistic regression analysis of more than 17,000 cervical smears. the relationship was investigated between the score for each smear of five quality indicators and the presence of cytological abnormalities (chapter 6). The age of the patient and the identity of the screening laboratory technician were controlled for. As far as we know, this study represents the first of its kind that examines the relationship between smear quality and pathology on so large a scale and with careful control for so many quality character-istics and co-variables. As expected, we found a clear influence of the age of the patient and (although not significant) the presence of endocervical cells in the smears on the probability of finding cytological abnormalities. Surprisingly, however, we also found that inadequate smear fixation led to a sevenfold increase in the number of abnormal smears. The hypothesis that inadequate fixation may be responsible for a large number of false positive smears thus forces itself upon the investigator.

Also in this study, we checked in how far the quality assessments of the four laboratory technicians that screened the smears accorded. (chapter 7).

The percentage of agreement in the assessment of the presence of endocervical cells, after correction for the chance agreement (kappa) and after grouping and dichotomisation, is $0.56(95 \% \mathrm{BI}=0.49-0.63)$, which may be considered very reasonable. The concordance for the other indicators, not corrected for chance agreement, varied between 86 and 100. The computation of kappa values was virtually impossible in these cases, owing to the small number of smears that were assessed as poor (for the individual laboratory technicians the number is often zerol.

The most important part of our investigation was a controlled, randomised trial among 179 Flemish doctors con-cerning the effect of three methods of feedback of increasing intensity on the sampling quality of the smears obtained by these physicians (chapter 8). Following a baseline period of three months, the doctors were randomised in four groups: one control group (growp A) and three interven. tion groups (group $B_{*} C_{n}$ D). Subsequently, in the intervention groups a statement concerning the sampling quality of submitted smears was added to the customary laboratory reports. Moreover, the physicians in groups $C$ and $D$ were provided monthly with overviews of the detailed sampling quality assessments of the smears submitted by them during the past month. Included was a comparison between the results of every individual doctor with the mean of all smears received by the laboratory. Additionally, the subjects in group $D$ were sent, on indication, specific advice about improving the sampling quality of the smears taken by them.

For the doctors as a whole, we found a nonsignificant but systematically increasing effect of the feedback on the percentage per doctor of obtained smears 
containing pathologicall cells. Regression analysis demonstrated a significant decrease in the intervention quotient for the absence of endocervical cells in groups $\mathrm{C}$ and $\mathrm{D}$ to $75 \%$ of the values in the other two groups. For the doctors who submitted more than 50 smears during the period of study, increasing intensity of intervention was noted to be associated with a clear increase in the average percentage of endocervical cell-positive smears obtained per doctor, as well as in the average percentage of obtained smears generally assessed as "good" per doctor. There was no effect on the other quality indicators.

Probably, the provision of feedback - especially of the kind offered to the physicians in groups $C$ and $D$ - mainly leads to improvement of sampling quality when the doctor concerned obtains a number of smears that is sufficiently large for the feedback to wield its effect.

A specific outcome of this is that for the total number of smears prepared during the period of study, a reduction by $50 \%$ was observed both in the percentage of smears lacking endocervical cells and in the percentage of smears awarded a general quality assessment "poor" in groups C and D.

Quite unintentionally, it appeared from a telephone enquiry (chapter 9) that the number of doctors employing a qualitatively good sampling technique for obtaining cervical smears had doubled during the period of study. Hence we surmise that during some period of time the effect of our intervention will still increase rather than decrease. This hypothesis will be tested in a further study, that is at present being carried out.

Our intervention is both inexpensive and little labour-intensive. Also, from the answers provided in a written enquiry after the study was concluded, it was apparent that the involved physicians appreciated the feedback as we had offered it. Therefore we think that all conditions have been met for the application on a greater scale of the method that we have used or a comparable one, provided that it is carefully controlled.

We were alarmed at the high percentage of doctors that reported in an enquiry at the beginning of our study that they used the Cytobrush only for obtaining cervical smears. We feared that as a consequence, the probability of missing the transformation zone would be large, especially in women with erythroplakia. We tested this hypothesis in cooperation with the Leiden Cytological and Pathological Laboratory. who reassessed 444 , chiefly abnormal smears that were obtained with the combined Spatula + Cytobrush technique (chapter 10). For each of the two samples, the presence of pathological cells, endocervical or metaplastic cells, and squamous cells was recorded.

Use of the cytobrush only would, in this series, have rendered $3 \%$ of the smears lacking squamous cells, $3 \%$ false negative, and $7 \%$ underdiagnosed. In addition, a relationship existed between the probability of a false negative cytobrush smear and the absence of squamous cells in this smear.

Given the confirmation of our suspicions, we are of the opinion that cervical sampling with the Cytobrush only is bad practice, which must be abandoned as soon as possible. 
Our hypothesis that this concerns women with erythroplakia in particular, was investigated in a prospective, comparative study of cervical smears of women with and without an erythro-plakia (chapter 11). Our data did not vield support for the hypothesis. The size of the erythroplakia also appeared of no consequence. 


\section{DANKWOORD}

Een ruwe schatting leert dat zowat 300 mensen betrokken waren bil het tot stand komen van het onderzoek waarover in dit proefschrift gerapporteerd wordt.

Van meer dan 200 artsen werden de gegevens verwerkt. Hun namen vermelden is mogelijk noch wenselijk. Toch worden zij heel erg bedankt, vooral voor de interesse en waardering die bleek uit hun antwoorden op de enquête die zij invulden nadat zij van dit onderzoek op de hoogte gebracht waren.

De anatomopathologen, de laboranten van de cytologische affeling en de computerman van het Centraal Laboratorium te Antwerpen verdienen de grootste pluim. Hun interesse en inzet voar kwaliteitsverbetering maakten het beschrijvend onderzoek en de interventiestudie mogelijk. I $\mathrm{k}$ ben er mij van bewust dat het extra registreren van de kwaliteitsscores voor elk uitstrijkje gedurende elf maanden een niet te verwaarlozen bijkomende belasting betekende en ik ben dankbaar voor de bereidwilligheid en de volharding.

Het Leids Cytologisch en Pathologisch Laboratorium heeft een faam te verdedigen op het gebied van de continuë verbetering van de afnamekwaliteit van cervixuitstrijkjes. De bereidheid om zonder veel aarzelen mee te werken aan een onderzoeksproject van lemand die op dat ogenblik een wildvreemde was, heeft mij verbaasd en ontroerd. Mathilde Boon en haar staf hebben mijn hart gestolen.

Ook de gynaecologen en cytologen van het Academisch Ziekenhuis Maastricht die meewerkten aan de laatste studie uit dit proefschift deden dit belangeloos en met de grootste mate van bereidwilligheid. Zij verdienen mijn dank.

De huisartsen van Maasmechelen en de gynaecologen van het Maasland waren niet rechtstreeks betrokken bij de hier gerapporteerde onderzoeken. $\mathrm{Zij}$ speelden echter een doorslaggevende rol bij de vroegere onderzoeken die de start vormden van deze onderzoekslijn. Daarom zou dit proefschrift er zonder hun medewerking wellicht nooit gekomen zijn.

Overigens is het feit dat een onderzoeksinteresse kon vitgroeien tot een onderzoeksresultaat in de eerste plaats te danken aan de interesse en inzet voor een wetenschappelijk verantwoorde Huisartsgeneeskunde zoals ik die gedurende de afgelopen zestien jaar steeds opnieuw terugvond in de Maasmechelse Huisartsenvereniging en in de diverse echelons van de Wetenschappelijke Vereniging der Vlaamse Huisartsen. Niemand kan dit werk blijven doen als hij niet steeds opnieuw bevrucht wordt door collega's met dezelfde zorg voor kwaliteitsgeneeskunde.

Mijn promotoren hebben gedurende de voorbije jaren een belangrijke rol gespeeld. niet alleen in het tot stand komen van dit werk. maar vooral in mijn verdere groei als onderzoeker. $\| k$ heb gedurende deze periode meer geleerd dan ik tevoren voor mogelijk hield en dat heb ik volledig aan hen te danken. Het feit dat Harry Crebollder, Gerard Essed en André Knottnerus zulke fijne en bezorgde mensen zijn. maakte het vele werk daarenboven op éen of andere manier doenbaar.

Mijn aanstelling bij de Vakgroep Huisartsgeneeskunde van de Limburgse Rijks. universiteit was voor mij tevens de eerste kennismaking met het werken als 
onderzoeker binnen een onderzoeksgroep. Ik heb er een plezierige en enthousiaste ploeg leren kennen van mensen waarop ik vaiak voor allerliei kleine en grotere problemen kon terugvallen en ik ben hen dankbaar voor deze ervaring.

Bij de werwerking van de onderzoeksgegevens werd ik bijgestaan door verschil. lende mensen van het secretariaat met Ine Siegelaar op kop. Voor de extra druk die hierdoor op hun werkschema gelegd werd kan ik enkel verzachtende omstandigheden pleiten.

Een heel speciale rol werd gespeeld door Trudie Seegers die mij als researchassistente ter zijde stond, Niet alleen kreeg ik van haar een on the job opleiding D-Base voor gevorderden, maar zil initieerde mij tevens in de geheime wegen van VAX en BMDP. Door haar praktisch inzicht in analyseproblemen en door een grenzeloze hoeveelheid gezond verstand behoedde zij mij meermaals voor nutteloze omwegen en leidde zij mij efficiënt door doolhoven van ingewikkelde commando"s, vergeten punten en duistere functietoetsen.

Hubert Schouten speelde het op één of andere wijze klaar om mil binnen de grenzen van de statistische orthodoxie te houden. Ik vrees dat het niet gemakkelijk geweest is, maar $i k$ ben hem dankbaar dat hij deze vrijwillig opgenomen taak consequent tot een goed einde gebracht heeft.

De eindversie van dit proefschrift werd uitgetypt door Germaine Fraussen. Haar onbeperkte mogelijkheden om mijn wisselend werktempo te valgen hebben mij sinds vele jaren verbaasd, maar door haar werk is reeds veel gebeurd dat eerst onmogelijk leek.

Lieve en de kinderen hebben op sommige ogenblikken een belangrijk deel betaald van de prijs voor het resultaat dat nu ter tafel ligt. Betrokkenheid bij klinisch werk, bij opleiding van jonge artsen en bij wetenschappelijk onderzoek is een veeleisende opdracht, die al te vaak ten koste gaat van de aanwezigheid in het gezin. Lieve en Els waren daarenboven herhaaldelijk beschikbaar voor assistentie op ogenblikken dat tijd een rol ging spelen. Ik hoop dat het deel hebben aan dit werk ook voor hen een vruchtbare ervaring mag zijn, 


\section{CURRICULUM VITAE}

Frank Buntinx werd op 29 oktober 1950 geboren in Hasselt. Zijn middelbare schoolopleiding kreeg hij aan het St. Jozefscollege van dezelfde stad. In 1975 behaalde hij het diploma van Dokter in de Genees-, Heel- en Verloskunde aan de Katholieke Universiteit te Leuven. In 1977 volgde de erkenning als Huisarts.

Hij is gehuwd met Lieve Brams en vader van drie kinderen: Els, Walter en Marianne.

In 1975 vestigde hij zich als huisarts in Maasmechelen. Hij bekleedt bestuursfuncties in de vzw Huisartsen Maasmechelen, in de Wetenschappelijke Vereniging der Vlaamse Huisartsen en in de Europese wetenschappelijke huisartsvereniging (SIMG).

Sinds 1979 is hij lid van de redactie van Huisarts Nu. Van 1981 tot 1989 was hij redactievoorzitter. Van 1981 tot 1986 was hij daarenboven lid van de redactie van Allgemeinmedizin International General Practice.

In 1985 werd hij door de minister van Sociale Voorzorg erkend als Stagemeester Huisartsgeneeskunde en door het Interuniversitair Centrum voor Huisarts Opleiding als moderator. Sinds 1986 is hij moderator van de locoregionale groep te Genk.

Hij is als onderzoeker verbonden aan de Vakgroep Huisartsgeneeskunde van de Rijksuniversiteit Limburg te Maastricht en als wetenschappelijk medewerker aan het Academisch Centrum voor Huisartsgeneeskunde van de Katholieke Universiteit te Leuven. Daarnaast is hij lid van de algemene vergadering van het Vlaams Huisartsen Instituut.

In 1988 kreeg hij de tweejaarlijkse Prijs van de Vlaamse Huisarts. In 1990 kreeg hij, samen met enkele collega's, de tweejaarlijkse HANU.VHI Prijs voor het beste researchartikel. 
BHLAGE 1

FORMULIEREN GEBRUIKT VOOR DE MAANDOVERZICHTEN IN GROEP C EN D 
Frankrijklei, 67-69

B-2000 ANTWERPEN

Tell (03) 2313689

B.T.W. nihil

HAA 229.923

$P$ P.K $000-0618045-58$

K. $450-0393341.60$

Telelax (03) 2314167

U. Rel: :

O. Reti:

Antwerpen,

Geachte Collega,

Wij makkten ter uwer informatie een overzichtje van de technische kwaliteit van de cervixuitstrijkjes , die door $U$ tijdens de maand MAART 1990 ingestuurd werden.

Naast uw eigen gegevens vindt $U$ ook een overzicht van het gemiddelde voor alle cervixuitstrijkjes die wij gedurende deze mand ter beoordeling toegestuurd kregen.

Met vriendelijke groeten, 
NAAK :

ADRES :

HOONPLARTS :

TOTAAL AANTAL UITSTRIJRJPS :

KWALITEIT IS :

CELRIJKDOK U2ELF (aanta1len): (percentages):

CELRIJKDOM TOTAAL:

HOOPJES UZELF (aantallen):

$$
\text { (percentages): }
$$

KOOPJES TOTAAL:

ENDOCERVICAAL UZELF (aant.):

$$
\text { (perc.): }
$$

ENDOCER ICAAL TOTAAL:

FIXATIE UZELF (antallen):

$$
\text { (percentages): }
$$

FIXATIE TOTAAL:

INFECTIL UZELF: (anta11en):

$$
\text { (percentages): }
$$

INFECTIE TOTAAL:

ALGEMENE KWALITEITSBEOORDELING U2ELF: (aAntallen):

$$
\text { (percentages): }
$$

ALGEMENE RULTTETTSBYOORDELING TOTAAL:

\section{UITSTEKTND}

23

100.00

99.83

23

100.00

99.77

20

86.96

85.59

23

100.00

99.15

22

95.65

99.77

19

1

4.35

82.61

88.88

0.68 10.44

ONVOLDOLNDE

0

0.00

0.00

0

0.00

0.06

3

13.04

10.32

0

0.00

0.17

1

4. 35

0.23

3

13.04 
op basis van het maandoverzicht doen wij U enkele suggesties die de kwaliteit van uw uitstrijkjes wellicht ten goede komen :

In ....* van de gevallen bevat het uitstrijkje geen endocervicalen.

Dit is nogal eens te wijten aan:

- het niet volledig (360) randraaien van de spatel van Ayre over de portio.

- Het niet of onvolledig uitstrijken van de avergangszone tusen endocervikaal en ectocervikaal epitheel. Dit is vooral moeilijk als deze overgangszone zich binnen de cervixhals bevindt. (Komt vaak voar bij postmenapausale vrouwen).

CAVE; Uit meerdere onderzoeken blijkt dat de kans op het vinden van pathologie omgekeerd evenredig is met het antal endocervikalen in het uitstrijkje. Met een witstrijkje zonder endacerwikalen heeft $U$ dus een duidelijke kans om aanwezige pathologie te missen. Een hulpmiddel om een correcte afname te wergemakkelijken kan zijn :

- Het gebruik van de cytabrush nast de spatel van Ayre. Dit levert $U$ een staal, gemaakt met de spatel wan Ayre en een ander staal gemaakt met de cytabrush, die $U$ beide samen meegeeft.

In september ontuing $U$ een tekst met richtiljinen var de afname van een cervixultstrijkje, ander meer met gebruik van de cytobrush.

Cytobrushborsteltjes kan u gratis van het laboratorium bekamen. Wanneer $U$ dit wenst kan $U$ dit bestellen via het bijgevoega bestelformulier dat $U$ meegeeft met de ophaaldienst.

- Wanneer er erg veel cervixslijm is, is het aan te raden dit met een tamponnetje of een lcc-spuitje te verwijderen alvorens het uitstrijkje te maken.

Er is een wideo beschikbaar warop de volledige witstrijktechniek wordt gedemonstreerd. U kan een copie hiervan gratis ontlenen en de band gedurende een week op uw gemak bekijken. Als U dit wenst, kan $U$ zulks aanduiden op het bijgevoegd bestelfarmulier. 


\section{$\mathbf{C}_{\text {centraal }}$}

In ... gevallen was het uitstrijkje niet voldoende correct gefixeerd.

Dit kan te wijten zijn aan:

- Meer dan 5 seconden tijdsverloop tussen het afstrijken op het glaasje en het fixeren: deze cellen drogen snel an de lucht en kunnen dan niet meer gefixeerd worden.

spuiten van te karte afstand: de cellen warden dan vaak weggeblazen of bevraren.

- Spuiten van te grote afstand: dan is er onvoldaende fixatie.

- Schuin spulten: de cellen worder naar 1 kant gedumd en liggen daat op een hoopje.

Gebruik van haarlak kan vacualen in de celkern veraarzaken die de interpretatie bemailijken.

Volgende tips kunnen $U$ helpen bij het carrect fixeren:

- Fixeer zo snel mogelijk na het afstrijken van spatel of cytobrush op het glaasje. Iedere seconde is daarbij belangrijk.

In de praktijk betekent dit dat U de fixeerspray binnnen handbereik heeft als $u$ een uitstrijkje makt en dat $U$ het eerste glaasje meteen fixeert, nag voor $U$ het tweede uitstrijkje makkt. Als het speculum ondertussen niet wilot blijft zitten, kan $U$ aan patiente vragen om het oven vast to houden.

- Maak gebruik van de doar het laboratorium geleverde spray.

- Spuit loodrecht op het glassje, van op een afstand wan ongeveer $20 \mathrm{~cm}$.

Wacht tot de fixatievioeistof opgedroogd is alvorens de glaasjes in de houder te brengen. Dit kan even duren.

In september ontving $U$ een fotoreportage met beelden van uitstrijk-en fixatietechniek. Hierover is ook een video beschikbaar. U kan een copie van de band ontlenen en hem gedurende een week op uw gemak bekijken. Als $U$ dit wenst, kan $U$ zulks aanduiden op het bijgevoegd bestelformulier. 
In .... * bevat het uitstrijkje erg weinigg epitheelcellen.

$U$ heeft meer kans op een laag aantal cellen bij postmenopauzale vrouwen. Daarenboven is dit nogal eens te wijten aan:

- Een afname die (vrijwel) uitsiuitend ter hoogte van de exocervix gebeurt en niet endocervical.

- Bij het afstrijken van spatel of cytobrush op het objectglaasje is er niet voldoende hard geduwd.

- Het afivrijuen van de cytobrush op het objectglaasje in plaats van het afrollen.

Am dit te vermijolen kan $U$ best:

1) Steeds 2 uitstrijkjes maken, die U samen opstuurt: eentje ter hoogte van de exacervix met de spatel en eentje ter hoogte de endacervix met de cytobrush.

2 Erover waken dat $U$ de cytobrush correct afrolt op het glasuje.

$U$ vindt dit utvaerig beschreven in de fatarepartage, die $U$ in september toegestuurd kreeg en warvan $U$ desgewenst altijd een copie kan aanvragen.

3) Wanneer U kan kiezen, gebeurt een uitstrijkje best in de periovulatolre periade.

Er is een video beschikbaar warap de volledige uitstrijktechniek wardt gedemonstreerd. U kan een copie hiervan ontlenen en de band gedurende een week op uw gemak bekijken. Als $u$ dit wenst kan $U$ het aanduiden op bijgevoegd bestelformulier. 
In ... uitstrijkjes waren er duidelijk tekens van inflamatie aanwezig.

Het is niet aan te raden een uitstrijkje te maken wanneer 4 een duidelijke vaginale of cervix infectie vaststelt. Inflammatie maakt een uitstrijkje moeilijk te beoordelen, zelfs wanneer de uitstrjjktechniek perfect was.

In geval wan infectie is het dan ook aangewezen eerst de infectie te behandelen en het uitstrijkje pas na de behandeling te maken. $U$ kan dit dan cambineren met een contrale van uw behandelingsresultaat. 
In .... van de uitstrijkjes vindt men een matig tot groot aantal moeilijk beoordeelbare celhoopjes.

Misschien kunnnen volgende tips $u$ helpen om dit te vermijden.

1) Waak er zorgvuldig over dat het afstrijken wan spatel of cytobrush op het abjectglaasje op een egale manier gebeurt: vooral bij de spatelafname is het belangrijk dat $U$ :

- stevig aandrukt tijdens het uitstrijken

- in 1 enkele streek afstrijkt . maak desnoads 2 parallelle Litstrijken op het glaasje, maar alleszins geen zig-zagbeweging.

- strijk af tot aan de rand van het glaasje : niet halfiveg stoppen.

2) Wees voorzichtig bij het nemen van het uitstrijkje. Het heeft geen enkel voordeel van met spatel of cytobrush hard op de cervix te duwen. 


\section{VERSCHILLENDE CLASSIFICATIES \\ VOOR CYTOLOGISCHE AFWIJKINGEN VAN DE CERVIX}

\begin{tabular}{|c|c|c|c|c|}
\hline Beald & PAP & CIN & KOPAC & SIL \\
\hline Geen efwifkingen & 1 & & 1 & \\
\hline Abnormale plaveiselcellen & \multirow[b]{2}{*}{11} & & 2 & \multirow{3}{*}{ LOW GRADE } \\
\hline $\begin{array}{l}\text { Atypische squameuse metapla } \\
\text { sie }\end{array}$ & & & 3 & \\
\hline Geringe dysplasio & \multirow[b]{2}{*}{ Hila } & 1 & 4 & \\
\hline Matige dysplasie & & 踝 & 5 & \multirow{5}{*}{ HIGH GRADE } \\
\hline Ernstige dysplasie & Hlb & \multirow[t]{4}{*}{ 111 } & 6 & \\
\hline Carcinoom in situ & W & & 7 & \\
\hline Microinvasief carcinoom & \multirow[b]{2}{*}{$v$} & & \multirow[b]{2}{*}{9} & \\
\hline Irvasief carcinoom & & & & \\
\hline
\end{tabular}

Nota:

Deze classificaties zijn met gedeeltelijk verschillende bedoelingen an uit een versichillende achtergrond opgesteld. De verschillende categorieeren zijn dan ook niat zonder meer wolledig omzetbaer. Daarenboven worden binnen ean aental classificaties ook andere factoren gecoeteerd dan alleen de afwijkingen van cilinder. en plaveiselepitheel, die in dit schema samemgevat zijn. Dit schema theeft alleen de bedaeling als wuistregal te dienen bij de vergelijking. 
as

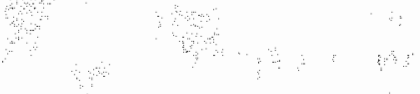

$\because$

का

$\because)^{2}$ 


\section{LITERATUUR}

1. Affandi M. Use of hairspray as a fixative. Acte Cytol $1989 ; 33: 419$.

2. Allingham JD, King A. Patient characteristics and endocervical cell recovery on Papanicoiaou smears. J Fram Pract 1985; 20: 185-190.

3. Alons-van Kordelaar JJM, Boom ME. Diagnostic Accuracy of Squamous Cervical Lesions Studied in Spatula-Cytobrush Smears. Acta Cytol 1988; 32(6): 801-804.

4. Anoniem. Cervical cancer screening: the pap smear - summary of a NIH consensus statement. Br Med J 1980; $281: 1264-1266$.

5. Anoniem. Cytological screening in the control of cervical cancer: technical guidelines. World Weath Organization Geneva 1988.

6. Anoniem. NHG-standaard. Cervixuitstrijken. Huisarts Wet 1989;32:473-477,

7. Anoniem. Statgraphies Version 2.1: User's Guide. Rockville: STSC 1986 :

8. Armitage P. Berney G. Statistical methods in medical research $2^{\circ}$ Ed. Oxford; Blackiwell scientific publications, $1987: 559 \mathrm{p}$.

9. Avonts D, Embrechts P. Contimgentietabellen deel 1: De chi-kwadraattoets. Huisarts Nu 1988: 1719): $467-470$.

10. Avonts D, Embrechts P. Hoe zeker ben je van een berekende waarde? Huisarts Nu 1988; 17:69-73.

11. Ayre JE, Cervical cyrology in diagnosis of early cancer. JAMA 19.48; 136: 513-517.

12. Ayre JE. Selective cytology smear for diagnosis of cancer. Am J Obstet Gynecol 1947; $53: 609$. 617

13. Baker RM. Improving the adequacy of pap smears: AFP 1989; 39: 109-114:

14. Beibly J, Boume R, Guillebaud J, Steele S. Paired cervical smears: A method of reducing the falsenegative rate in population screening. Obst Gyrn 1982; $60: 46.48$.

15. Bewtra C. Columnar Cells in posthysterectomy vaginal smears. Acta Cytol 1989; 33: 721 .

16. BMDP.statistical software (Ed), BMDP manuals. Bierkely: University of California Press: 1989.

17. Boon ME. De cytobrush-methode. Een mididel ter verbetering van de kwaliteit wan door huisartsen gemaakte cervixuitstrijken. Huisarts Wet $1985 ; 28 ; 322-324$.

18. Boon ME. Het optimale cervix-uitstrijkje door de huisarts. Patient Care (Nederland se uitgavel. maart 1989: 111-21.

19. Boon ME. Het optimale cervixuitstrijkje. Practitioner (Nederlandse uitgave) 1991: 8(11: 31-35.

20. Boon ME, Alons van Kordelaar JJM. Kwaliteiteitsverbetering door middel van de gecombineerde spatel-cytobrushmethode. Jaarverslag 1985 wan thet Leids cytologisch Laboratorium.

21. Boon ME, Alons-van Kordelaar JJM, Rietveld-Scheffers PEM. Consequences of the combined spatula and Cytobrush sampling for cervical pathology. Actei Cytol 11986; 30:264.270.

22. Boan ME, Beck S Door huisartsen uitgevoerd bevolkingsonderzoek op cerwixcancinoom. Med Contact 1991:46:23-25.

23. Boan ME, Graaff JC de. Nederlandse huisarts heeft hogere scores positieve cervixuitstrijken dan bevolkingsonderzoek. Med Contact 1987; 13:407.408

24. Boon ME, Graaff JC de. De spatel en het oog: uitstriktechniek on macroscopisethe beoordeling cervix uteri. Med Contact 1986; $41: 477: 478$

25. Boon ME, Graaff JC de. Wat heet "medische indicatie" ? Soclaat. anamnestische gegevens onderdeel van selectie voor uitstrijk. Med Contact 1986; 41:1587.1588.

26. Boon ME, Graaff JC de, Rietveld WJ. Analysis of Five Sampling Methods for the Preparation of Cervical Smears. Acta Cytol 1989; 33161: 843-848.

27. Bourne R, Beilby JO. Trial of new cervical spatula. Lancel $1976 ; 13301331$.

28. Bouter $L M$. Ter Riet $G$. Meta-analyse van therapeutische experimenten I: Bronnen van vertekening in literatuuronderzoek. T Soc Gezondheidsz 1990; 68: 179.185.

29. Brink AL, DU Toit JP, Deale C.JC. In search of more representative cervical cytology. SAMT 1989; 76: 15.17 .

30. Brock CD, Ornstein SM, Litchfield L. McKeag DB. An improvement techniclue for papanicofaou smear sampling in postmenopausal women. J Fam Pract 1986; 22:498-500. 
31. Bulpit Cu. Meta-analysis. Lancer 1988:93:94.

32. Buntinx $F$, Boon ME, Beck. S. Knotnerus: JA, Essed GGM. Comparison of Cytobush sampling. spatula sampling and combined Cytobrush-Spatula sampling of the uterine cervix. Acta Cytol 1991: 35: 64-68.

33. Duntinx F, Brams L. Cenwxuitstritikjes bil Maasmechelse vrouwen. Huisarts Nu 1984; 13:60-64.

34. Uuntinx F, Crebolder HF IM, Essed GGM, Knottnerus JA. Literatuuroverzichten en meta-analyse. Deel 1: een kwaltatieve benadering. Huisarts Nu 1991; 20:160-165.

35. Buntinx F, Crebolder HFJM, Essed GGM, Knottnerus JA. Geographical influencies on the sampling quality of cervical smears. Eur $J$ Obst Gynecol Reprod Biol: aanvaard voor publicatie.

36: Duntinx F, Crebolder HFJM, Essed GGM, Knottnerus JA. Afnamekwaliteit van cervixuitstrijkjes: Een beschrivend onderzoek. Huisarts Wet $1991 ; 34: 457.461$.

37. Buntinx F, Crebolder HFJM, Knottnerus JA. Cervixuitstrijkjes: afnamegewoonten en ervaringen. Huisarts Nu 1991; $20: 13-16$;

38. Buntinx F, Crebolider HFJM, Knotmerus JA, Essed GGM. Cervical smear sampling quality ILetter to the editor). Lancet $1991: 337: 926-927$.

39. Buntinx F, Essed GGM. Het maken wan cerviluitstrijkjes: Huisarts Nu 1989; 18; $291-296$.

40. Buntinx $F$, Knottnerus JA, Crebolder HFJM. Essed GGM. In search of good quality cervical smears * literature review. in Pas 4 . Concerted Action on General Pfactitioners involvement in cancel prevention. - General reviews. Report for the COMAC-MSR. in druk 1991.

41. Buntinx F, Knottnetus JA, Crebolder MFJM, Essed GGM. Literatuuroverzichten en meta-analyse. Deel 2: Bundeling van de fesultaten vam verschillende studies. Huisarts Nu 1991; 20:208-211.

42. Buntinx. F, Knottinerus JA, Crebolder HFJM, Essed GGM, Schouten H. The relationship between sampling quality and the probability of pathology in cervical smears. Brit Med $\mathrm{d}$ : aanvaard voor publicatie.

43. Buntinx $F$, Lehert Changes in the cerwical screening habits of G.P."s and gynaecologists in Masmechelen (Belgium). Allgrmeinmedizin 1989; 18: 1-4.

44. Buntinx F, Lehert P. Hysterectomieen bij Maasmechelse vrouwen. Huisarts Nu 1987; 16:286-287.

45. Buntinx $F$, Lehert $P$. Het effect van een sensibiliseringsciampagne op het aantal cervixuitstrijkjes in Maasmechelen, Hulsarts Niu $1987 ; 16: 319-325$;

46. Burghardt E. Latest aspects of precancerous lesions in squamous and columnar epithelium of the cervix. Int J Gyn obst $1970 ; 8: 573,580$.

47. Cecchini S, Grazzini G, lossa A, Bartoli D, Clatto S. Criteria for adequacy of cervical cytologic sampling. Acta Cytol 1989;33:687.

48. Centrum voor Kankerprewentie UlA. Interimrapport: Screening op baarmoederhalskanker. Antwerpen: UIA.

49. Chalmers I, Enkin M, Keirse M. Effective Care in Pregnancy and Childbirth. Oxford: Oxford University Press 1990.

50. Chalmers TC, Frank CS, Reitman D. Minimizing the three stages of publication bias, $M A M A$ 1990; 263: $1392-1395$.

51. Chang AR. An evaluation of cervical smears consisting of spatula and Cytobrush samples. Aust NZ J Obst Gyn 1989; 29:436.438.

52. Cohen JA. A coefficient of agreement for nominal scales: Educ Psychal Meas 1960; $20: 37-46$.

53. Coleman M, Watrendort ل J. Directory of on-going research in cancer epidemiology $1989-1990$. Lyon: IARC 1989.

54. Collins $R$, Yussuf $S$, Peto $R$. Overview of randomised trials of diuretics in pregnancy. Br Med J $1985 ; 290: 17-23$;

55. Colon VF, Linz LE. Corvical cytalogy. J Fam Pract 1983; 16: 224.

56. Craig S. The smear test. Aust Fam Phys 1985; 14: 1092-1094.

57. Dean AD, Dean JA, Burtion AH, Dicker RC. Epi Into, version 5: a word processing, database and statistics program for epidemiology on microcomputers. Stone Mountain: USD 1990:

58. Deckert JJ, Staton SF, Pallermo V. Improwed endocervical cell yield with cytobrusti. I Fam Pract $1988 ; 26 ; 639.641$.

59. Detweiler RE, Castilleja RM, Sneige N. Endociervical columnar cells and adequacy of cervical samples; analysis of 43 discordant smears and cervical biopsies. Acta Cytol 1989:33: $730-731$.

60: Detweiler JJ, Staten SF, Palermo W. Improved endocervical ceel vield with cytobrush. J Am Pract $1988 ; 26: 639-641$ 
61. De Vet HCW, Knip schild PG, Schouten HA, Koudstaal J, Kwee WS, Whilebrand Di Sturmans F. Arends JW. Interobserver vartation in tristopathological grading of cervical dysplasia J Chin Epidemiol $1990 ; 43: 1395$; 1398 .

62. Dickersin $K$. The existence of publication bias and risk factors for its occurence. JAMA 1990; 263; $1385 \times 1389$.

63. Dickersin $K_{,}$Higgins $K$, Meinert $C$. Identification of meta-analyses. Controlled Clin Trials 1990; 11 : $52-66$.

64. Diem K. Lentner C. Scientific Tables, Basel Ciba-Geigy, 1978

65. Donner A, Brown KS, Bracher P. A methodological review of non therapieutic interwention trials employing cluster randomization 1979m 1989. Int J Epidemiol 1990; 19:795-800

66. Donner A, Donald A. Analysis of data arising from a stratified diesign with the cluster as unit of randomization. Stat. Med. 1987;6:43-52.

67. Doornewaard $H$, Graaf $Y$ van der. Contribution of the Cytobrush to determining cellular composituon of cervical smears. J Clin Pathol 1990; 43:393-396.

68. Dotters DJ. Carney CN, Droegemueller W. Nylon brush impraves collection of cervical cytologic specimens, Obst Gyn 1988; 159:814:819:

69. Eddy DM, Hasselblad W. Shachter R. An introduction to a Bayesianmethod for meta-analysis: The confidence protile method. Med Decis Making 1990; 10:15.23.

70. Eisenberg JM, Williams SV. Cost containment and changing Physicians' Practice behavion. Can thie fox learn to guard the chicken coop? JAMA 1981:246:2195-2201.

71. Elas $A$, Linthorst $G$, Bekker $B$, Vooils PG. The significance of endocervical colls in the diagnosis of cerwical epitheliat changes. Acta Cytol 1983;27:225-229.

72. Ende J. Feed-back in Clinical Medical Education. JAMA 1983;250:777.781.

73. Engels $H$, Weyler J, Eylenbosich WJ, Dooren $D$ van. Kwaliteit van uitstrijkjes genomen met een cervex-brush. Tijdschr Geneesk 1990; 46: 689-695.

74. Erp EJM van, BlashekLut CHM, Arentz NPW, Trimbos JB. Performance of the crtobrush in patients at risk for cervical pathology: does it add anything to the wooden spatula? Eur Jy Gyacol Oncol 1988: 6: $456-460$.

75. Erp EJM van, Dersjant-Doorda MC, Arentz NPW, Stinen Th; Trimbos JB. Should the cytobrush be used in routine screening for cervical pathology? Int J Gyniecol Olostet 1989; $30: 139 \cdot 144$.

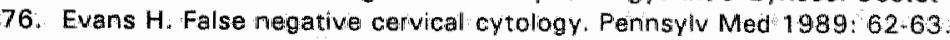

77. Fleiss JL. Statistical methods for rates and proportions. New Yark: John Wiley 1981.

78. Fleming DM, Lawirence MSTA. limpact af audit on preventive measures. Br Med J 1983; 287: 1851-1854.

79. Fraser CG, Woodfard FP. Strategies to modify the test-requesting patterns af clinicians. Ann Clin. Biochem 1987; 223:23\%.

80. Frierson HF, Covell $J$; Anderson WA. Pastradiation changes in endocervical cells in endocervical brushing specimens. Acta Cytal 1989; 33:709.710.

81. Frish L. Inflammatory atypia. Acta Cytol 1987:31:869:872

82. Gardner MJ, Altman DG. Confidence intervals rather than prvalues: estimation rather than hypothesis testing: Br Med J 1986; 292:746; 750

83. Gardnar $\mathrm{MJ}$, Gardner SB. Winter PD. Confidence interwal analysis - microcomputer program mentual. London: Br Med J; 1989.

84. Garte T, Feldman M. An evaluation of cytologic sampling techniques: A comparative study. Actea Cytoll $1978 ; 22: 83-85$;

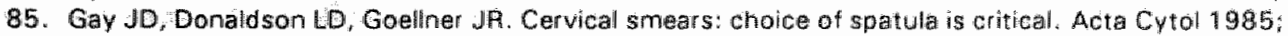
29: $1156-1157$.

86. Gay JD, Donaldson LD, Goelner JR. False-negatiwe results in cervical cytologic studies. Acta Cytal $1985 ; 29: 1043-1046$

87. Gehlbach SH. Fever in chidren younger than three months of age: A pocied analysis. J Fam Pract $1988: 27: 305-312$.

88. Gianrossi $R$, Detrano $R$, Mulyihill D, Leitmann $K$, Dubach $P$, Colombo $A$, et all, Exercise-induced ST depression in the diagnosis of coronary antery disease: A meta-analysis. Circulation $1989 ; 80: 87$. 98.

89. Giass GV. Primary, secondary and meta-analysis of research. Educ Fers 1976: $5: 328$

90. Glenthoi A. Bostofte E, Rank F. Brush cylology trom the uterine cervix. Acta Obstet Gynecol Scand 1986; 65:689-691. 
91. Glenthol A. Runk F, Peen U, Bostohe E Dagnostc efficiency of brush cyloboy from the uterine

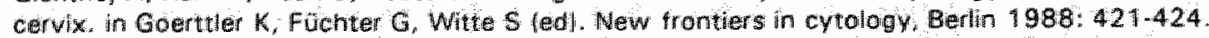

92. Gommey BP, Lacey CJN. Suthon J. Ayre Aylestury cervical spatulas. Genitour Med 1989. 65: $161 \cdot 162$.

93. Graf $Y$ wan ther, Vooils GP, Gaillard HLJ, Go OMDS. Screening errors in cervical cytologic screming. Acta Cytol $987,31,434-438$

94. Gray JAM, Continuing Education what techniques are Effective? Lancet 11986:447-448.

95i. Greening SE. The adequate Papanicolaou smear revisited Dian Cytopathol 1985; $1: 55-158$.

96. Giffiths: $M$, Turmer $M$ Partington CK, Souter Wh. Should mears in a colposcopy etinic be taken atter the application of actic acid? Acta Cyto $1989,33,324 \times 326$,

97. Groctenhuis A, Grootenhus Wuikk C, Brouwer A. Wie strikt in de praktijk? Huisarts Wet 1989; 32 $168-169$.

98. Gupta RK, Naran $S$, Bakalar A, Fauck R, Buchaman A, Improvement in the quality of gynaecologic smears using a cytobrush N Z Medical J $1987 ; 100,532-534$.

99. Gustavson T. Eplstat (softiviarel Round Rock. 1985.

100. Hadimichai $\mathrm{O}$, Janerich D, Lowell DM, Wister Meigs $\mathrm{J}_{\mathrm{f}}$ Merina MU, Schwarts PE. Histologic and elinical charateristics associated with rapldly progresslwe invasive cervical cancer a preliminary report from the Yale cancer control research unit. Yale JBiology Med 1989; 62:345.350.

101. Hamblin JE; Brock CD, Ltehfield L, Dias J. Papanicolaou smear adequacy: effect of different techniques in specific tertility states. J Fam Pract $1985 ; 20: 257-260$

102. Hanselaar AGJM, Voois GP. Doel en techniek van de cervixuitstrik. Utrecht, Bunge 1983:

103. Havens RB, Davis AD. MC Kibben A, Tugwell P. A Critical Appraisal of the Efficacy of Continuing Medical Education. JAMA 1984, 251:61-64.

104. Hayes PC, Davis JM, Lewis JA, Bowchier IAD. Meta-analysis of value in prevention of variceal haemorhage. Lancet 199; 336:153.156.

105. Hedges LV, Okin I, Statistical methods for meta-analysis Orlando; Academic Press Inc 1985.

106. Hedrick SC, Koepsell TD, Inu $T$, Meta-analysis of home care effects on mortalty and nursinghome placement. Med Care 1989; 27; 1015-1026.

107. Hellberg D, Axelsson D, Gad A, Nilsson S. Conservative management of the abnormal smear during pregnancy. Acta Obstet Gymecol Scand 1987;66:195-199.

108. Mendersion WG, Goldman $\mathrm{S}$, Copeland JG, Moritz TE, Harker LA. Antiplateliet or anticoagulant therapy after corchary artery bypass surgery. A meta-analysis of clinical trials. Ann Intern Med $1989 ; 111: 743,750$.

109. Hicklin MD, Watts JC, Plott AE, Wood RJ, Coleman SA, Johnston WW, Naib ZM, Astuton PR, Rube IF, Recalde AL. Petrospective evaluation of gynaecologic eytodiagnosis. Acta Cytol 1984; 28: 58.71 .

110. Howgson MJ, Parkinson DK, Kapp Mi Chest X-rays in thypersensitivity pneumonitis: a metaanalysis pf secular trend. Am J industr Med 1989:16:45.53.

111. Hofmans EA. Publicatiebias - realiteit of mythe? Huisarts Wet 1990; 33:14-15:

112. Holm KK, Grinsted P, Poulsan EF, Fenger C. Can hairspray bie used as smear Fixative? A comparison between two types of colting flxativers. Acta Cytol 1988; $32 ; 422-424$.

113. Holm K, Grinsted P. Poulsen EF, Fenger C. Use of hairspravas a smear fixative. Acta Cytol 1989: $33 ; 4.19$.

114. Hoimquist MD. The effect of distance in aerosol fixation of cytologic specimens. The cytotechnologist's bullet in 1978: 15:25-27.

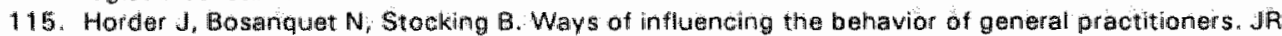
Coll Gen Pract 1986; 36; $517-521$.

116. Husan $O$, Butlar EB, Woodford FP. Combined external quality assessment of cytology and histology opinons: a pilot scheme for a cluster of five laboratories. J Clin Pathol 1984,37:993. 100 前.

117. Jenniceck M. Meta-analysis in medicine: Where we are and where we want to go: 1 clin Epidemiol $1989 ; 42: 35 \times 44$.

118. Johaingen P, Arfmann $E$, Pellesen G. Evaluation of smears obtained by cervical screping and an endocervical swab in the diaginosis of neoplastic diseaese of the uterine cervix. Acta Obstet Gynecol Seand 1979; $58: 265-270$.

119. Kairys $\mathrm{K}$, Knabour Al Kairys L. Papanicolaou smears of patients wearing a pessary: a diagnostic dilemma. Acta Cytol 1989; 33: 720-721. 
120. Kane R, Bailey RO. Evaluation of a postgraduate educational programme early cancer detection. $\mathrm{Br} J$ Med Education 1971; 5 : 134.137.

121. Kawaguchi K, Nogi M, Ohya M, Nishikawa Y, Kobayashi TK. The value of the evtobirush Her obtaining cells from the uterine cervix. Diagn Cytopathol $1987,3: 262-267$.

122. Kern DE, Harris W, Boekeloo BO, Barker LA, HogelandP. Use of an outpatient Medicit Record Audit to Achieve Educational objectives, J Gen Intern Med 1990; $5: 218-224$.

123. Killough BW, Clark AH, Garvin JB. Correlation between cytodiagnosis and the presence of endocervical or squamous metaplastic cells in gynecologic snoars. Acta Cytol $1988,32.758$.

124. Kinney JR, Piraino PS, Strumpt KB, Schmidt S Analysis of altered endocervical cells observed in cytobrush smears: Acta Cytol 1990; $34: 35$.

125. Kirk RS, Boon ME. A comparison of the efficiency of diagnosis of early cervical carcinoma by General Practioners and cytology sciteening in the Netherlands. Acta Cytol 1981:25:259-262.

126. Kivlahan $C_{n}$ Ingram E. Improved yield of endocervical cells on Papanicolaou smears in residency setting. J Fam Pract $1985 ; 20: 381,385$.

127. Kivlahan $C$. Ingram E. Papanicolaou smears without endocervicat cells. Are they inadequate? Acta Cytol 1986, 30:258-260.

128. Kleinbaum DG, Kupper $L$, Muller KE. Applied Regresision analysis and other multivarlable methods Boston; PWS Knet: 1988 .

129. Klinkhamer PJJM, Vooljs GP, de Haan AFJ. Intra-observer variability in the quality assessment of cervical smear's. Acta Cytol 1989:33:215-218.

130. Knipschild P, Leffers P. Feinstein AR. The qualification Period, J Clin Epidemiol 1991:44: 461/. 464.

131. Knottherus JA, Volovics A. Medische statistiek en onderzoek n de huisartsgeneeskunde. Utrecht: Huisartsenpers 1990 .

132. Koss LG. The Papanicolaou test for cervical cancer detection: A Triumph and a Tragedy. JAMA $1989: 261: 737.743$.

133. Koss LG, Hicklin MD. Standards of adequacy of cytologic Examination of the female genital tract. Obstet Gynecoll $1974 ; 43: 792-793$.

134. Kristensen $G$. Hoitund $B$, Grinsted $P$. Efficacy of the cytobrush versus the cotton swab in the collection of endocervical cells. Acta Cytol 1989; 33: 849.851.

135. Kristensem $G B$, Jensen $L K$, Ejersbo $D$, Holund $B$. The efficiency of the cytobrush and catton swab in abtaining endocervical cels in smears taken after conization of the cervix. Arch Gynecol Obstat $1989 ; 246: 207-210$

136. Kuo AF, Stawnychy IR, Corzatt GF, Tekleab A. Adequacy af papanicomaou smears: comparison of spatula sampling with combined spatula-cytobrush sampling and analysis of the endocervical component. Acta Cytol $1990,34: 47$.

137. Laupacis $A$, Sackett DL, Roberts RS. An assessment of clinically useful measures of the consequences of treatment. N Engl J Med 1988; $318: 1728-1733$

138. Laverty CR, Farnworth A, Thurloe JK, Bowiditch RC. The importance of the cell sample in cerwical cytology: a controlled trial of a new sampling device. Med J Aus 1989; $150: 432-436$.

139. Light RJ, Pillemer DB. Summing Up: The science of teviewing research. Cambridge: Harward Univeritity Press, 1984 .

140. Lindhorst $G$; Lindert $A$ wan. De kwaliteit wan de cerwixultstrijk. Ned $T$ Geneesk $1978 ; 122: 1231$ 1232 .

141. Lubsen J: Mete tanalyse een commentaar. II Soc Gezontheisz 1990:68: 190.

142. Luthy DA, Briggs RM, Buyco A, Eschenbech DA: Cervical cytology Increased sensitivity with a second cervical smear, Obstet Gynecol $1987 ; 51: 713-717$.

143. Mahominey Mul. Publication prefudices: an experimental study of confirmatory bias in the peer review system. Cog Ther Res 1977; 1: 161-175.

144. Mauney M, Eide D. Sotham J. Aates of condyloma and dysplastia in Papanicolaou simears with and without endocervical cells. Diagn Cytopathal 1990; 6:18-21.

145. Mc Cormac $L$, Lew W, King G, Allen PW. Gynaecological cytology screening in South Australia: a 23-year experience. Mad A Aus 1988; 149:530-534.

146. Mc Cormick J. Cervical smears: questionable practice? Lancet 1989:207.209.

147. Mc Intry N. Popper K. The critical attitude in medicine: the need for new ethics. Br Med $\mathrm{J} 1983$; 287: 1919.1923.

148. Meiman F. Het literatuuroverzictit: waardevol door systematiek en structuur. Husarts Wet 1990; $33: 2-3$. 


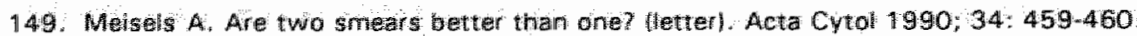

150. Metcalfe DHH. Audit in general practice. Br Med $\$ 1989,299,1293-1294$.

151. Mitchell Hedey G. Longhudiral study of women with niegative cervical smears acconding to endocervical status. Lancet $1991 ; 338: 265-267$.

152. Mitchell $H$, Medley $G$, Giles $G$. Cervical cancers diagnosed after negathe results on cervical cytolog: perspectwe in the 1980s; Br.Med.d. $1990 ; 300: 1622-1626$.

153. Mitchell MW, Fowkes FGR. Audut reviewed Does feed-back on pertormance change clinical behaviour? J.R. Coll Phys Lond $1985,19.251254$.

154. Mokkink H. Ziekentondscifers als parameter woor het handelen wam huisartsen. Dissertatie Kathollek Universiteit Nijmegen, 1986.

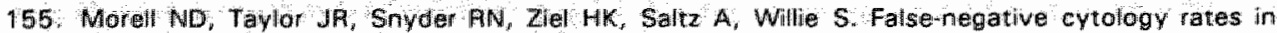
pattents in whom thwasive cervical cancer subsequently developed. Obstet Gynaeco: 1982;60: 41. 145 .

156. Maris JA, Gradner MJ. Callculating confidence intervals for retative risks lodds ratios/ and staindardised ratios and rates. Br Med, $1988 ; 296: 1313-1316$.

157. Murata PJ, Johnsom RA, Mchlcoll KE. Controlled evaluation of implementing the cytobrush technique to improve Papanicolaou mear quality. Obstet Gynecol $1990 ; 75: 690.695$.

158. Nagasawa M, Smith MC, Barmies JH, Fincham JE. Meta-analysis of correlates of diabetes patients' compliance with prescribed medications. Diabetes Educ 1990; $16,192-200$.

159. Naujoks H, Strohmeler R; Bicker T. Interobserver variability in the cytological diagnosis af 1500 Papanicoladu stamed cervicall monolayer specimens. Path Fes pract 1990; 186:150*153.

160. Neinstein LS, Rabinovitz $S$, Recalde A. Comparison of cytobrush with cotton swab for endocervim cal cytologic sampling. J Adoles Heatth Care 1989; 10:305-307.

161. Ornstein SM, Brock CD, Papanicolacu smear techniques. J Fam Pract 1989; 28: 17-18.

162. Papancolaou GN, Traut MF. Diagnosis of interine cancer by vaginal smear . New York: The Commonwealth Fund 1943.

163. Papancolaou GN, Traut HF. The diagnostic value of vaginal smears in carcinoma of the uterus. Am il Obst Gynecol $1941 ; 42: 193-206$.

164. Pas L. Concerted Action on gemeral Practitions involvement in cancer prevention - Repiort for the COMAC.MSA. in druk 1991.

165. Pistofides GA. The multispatula a new dimension in sampling the cervix. Lancet 1984, 12141215 .

166. Pistotides GA, Brown ER, Harris VG, Grainger JM, Spring JE, Carr JVL, Ch Papman MG. Detection of abnormal cervical smears. Acta Obstet Gynecol Scand 1988;67:153-154.

167. Pocock SJ. Clinical trials; a practicall approach. Chichester: Wiley \& sons 1983.

168. Reissman SE. Comparisom of two Papanicoloau smear techniques in a family practice setting. I Fam Piract 1988; $26: 525,529$ :

169. Richart RM. Screening techniques for cervical neoplasia, Chin Obstet Gynecol 1979; 22: 701\%713.

170. Richart RM, Vaillant HW. Influenice of cell collection techniques upon cytological diagnosiss. Cancar 1965: 18:1474:1478.

171. Alet G ter; Kleinen J; Knipschild P. De eflectiviteit van acupunctuur. Huiserts Wet 1989; 32 : 308.312 .

172. Roberson J, Gore H. Glandular cells in vaghal smears: some diagnostic pitfalls: Abstract: 38 th Annual Scientific Meeting, vol 34, 5; 1990: 731 .

473. Rothman K.j. Modern Epidemiology. Boston: Little, Brown and company, 1986.

I74. Rubio CA. A trap for atypical cells. Am J Obstet Gynecol 1977; 128:687-688.

175. Rubio CA. False negatives in cervical oytology: can they be avoided. Acta Cytol 1981: 25: $199-202$

176. Aubio CA. The faise negative smear: An Instrumental error? Acta Cytol 1977; $21: 500.501$.

177. Rubio CA. The false Negative smear; The trapping effect of collecting instruments: Obstet Gynecol $1977 ; 49: 576.580$

178. Rubio CA. Who is responsible for the false Negative Smear? Acta Cytol $1975 ; 19: 319$.

179. Rubio CA, Berolund $K$, Kock $Y$, Zetterberg $A$. Studies on the distribution of abnormal cells in cytologic preparations: Ill. Meking the simear with a plastic spatula. Am J Dbstet Gynecol 1980; $137: 843.846$.

180. Rubio CA, Berglund $K$, Kock $\gamma$. Studies on the distribution of abnormal cells in cytologic preparations:" IV. Impoitance of the topografical position of the cells in material collected by wooden spatiulas. Gynecol Oncology 1980; 10 : 146-151. 
181: Rubio CA, Carter CO. False-negative smears in gynaecological cytology Lantet $1979,979$.

182. Rubio CA, Kock Y. Berglund K. Studies on the distribution of abnomal cells in cytologle prepara tions: 1. Making the smear with a wooden spatula. Acta cytol $1980 ; 24: 4953$.

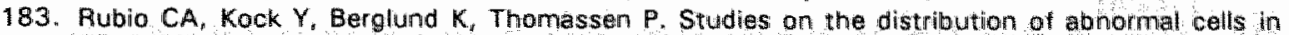
cytological preparations I. Making the smear with the cotton swab applicator. Gynecologic Oncology $1980: 9: 127-134$

184. Rubio CA, Kock Y. Studies on the distribution of abnornal cells in cytologic preparations $W$. The gradient of cell deposition on slides. Obstet Gynecol 1981; $57: 754.758$

185. Rublo CA, Kock Y. Thomassen P. Studies on the distribution of abnomal cells in cytologic preparations: VI. Pressure exerted by the gynecologist duting smearing. Gynecol Oncology 1983 ; 15: $391-395$.

186. Rublo $\mathrm{CA}_{n}$ Lagerhof $\mathrm{B}$. The false positiwe smear. Acta Cyto $1974 ; 18: 212.213$.

187. Ruffin. Improwing cervical smears (letter). N Z Med J $1988: 274-275$.

188. Russell Teagarden J. Meta analysis: Whither narrative review? Pharmacotherapy $1989 ; 9: 274$. 284.

189. Sackett $\mathrm{DL}$, Haynes RB, Tugwell P. Clinical Epidemiology A basic science for clinical medicine. Boston; Little, Brown and co 1985.

190. Schouten HJA. Nominal scale agreement among observers. Psychometrika 1986; 51:453-466.

191. Sedis A, Walters AT, Batin H, Hontz A, Lo Sciuto L. Evaluation of two simultaneusily obtained cervical smears. Acta Cytol 1974:18:291-296.

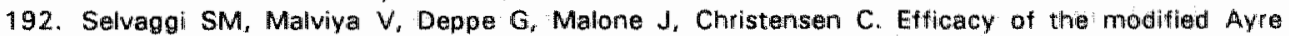
spatula/Zelsmyr cytobrush versus the modified. Ayre spatula/Bulb aspirator in the collection of cells from the uterine cervix. Acta Cytol $7989 ; 33: 697-698$ :

193. Sharp DW. What can and should be done to reduce publication bias? The pierspective of an editor. JAMA 1990; 263: 1390-1391.

194. Shen JT; Nalick RH, Schlaerth JB; Morrow CP. Efficacy of cotton-tipped applicators for obtaining cells from the uterine cervix for Papanicolaou smears. Acta Cytol 1984; 28: 541-545.

195. Shingleton HM, Gore H, Straughn JM, Gondios B, Marshall D, Ostergard DA. Improving cervical smears. N Z Med J 1988; $101: 200$.

196. Shinton RA, Beevers DG. A meta-analysis of mortality and coronary prevention in hypertensive patients treated with beta-receptor blockers. JHuman Hypert 1990; 4(suppl 2):31-34.

197. Shulmann JJ, Hontz A, Sedilis A. Walters AT, Ballin H, Lo Sciuto L. The Pap sinear: take two. Am Jobstet Gynecol 1975, 121: 1024-1028.

198. Skrabanek P. Cervical Cancer screening the time for reappraisal Can $\rfloor$ Public Health $1988 ; 79:$ 86-89.

199. Slot-van der Goot H. Indicaties voor portioscireening. De waarde van leettijd en klachten. Med Contact $1991 ; 46: 25-26$.

200. Smith N. The feasibility and desirability of experimental methods in evaluation. Evaluation and Program Planning 1980; 3: 251-256.

201. Soumererai SB, Mc Laughlin TJ, Avorn d. Quality assurance for drug presicribing. Oual ASS Health Care $1990 ; 2: 37-58$.

202. Sprij $B$, Casparie $A F$, Grol $\mathbb{R}$. Interventiemethoden am een werandering in de medische praktikvoo. ring te bewerkstelligen; wat is effectief? Ned Tildschr Geneeskd 1989; 133:1115-1118.

203. Spurrett $B$, Ayer $B$, Pacey NF. The inadequacies of instruments used for chervical screening. Aust NZ J Grnaecoll $1989 ; 29: 44-46$.

204. Stampfer MJ, Willett WC, Colditz GA, Speizer FE, Henmekens CH. Past use of oral contraceptivas and cardiovasicular diseese: A meto-analysis in the context of the nursest health study. Am J Obstet Gynecol 1990; $163: 285-291$.

205. Steiner $C$. Cervical cancer sicreening from the public health perspective. Acta Crtol 1989; 33: 471.474 .

206. Stock RJ, Thurmond Al, Passmore A. A comparison between the accu-Pap dewice and the extended-tip wooden Ayre spatula for cervical cytology sampling. Acta Cytol 1988; $32: 307-310$.

207. Taylor PT, Andersen WA, Barber SR, Covell JL, Smith EB, Underwood PB. The seriening Papanicollaou smear: contribution of the endocervical brush. Obstet Gynecol 1987; $70: 734-738$.

208. Ter Riet $G$. Bouter LM. Metaranalyse van therapeutische experimenten II: Voorstel tot een protocol. T Soc Gezondheidsz 1990; $68 ; 186-189$.

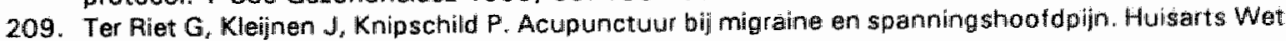
$1989 ; 32: 258-263$. 


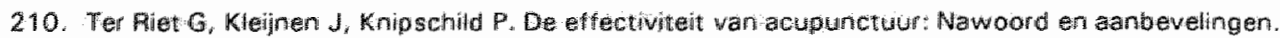
Huisarts Wet 1989; $32: 308-312$

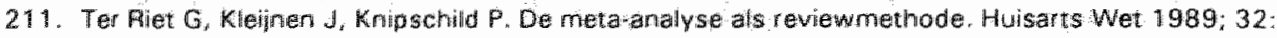
176.181 .

212. Trimbos JB, ArentzNPW. The ef ifciency of the ey tobusthersus the cotwon swab in the collection of endocervical cells in cervical smears. Acta Cytol 1986; 30; 26:-263.

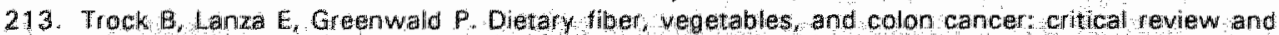
metanalyses of the epidemiologic evidence. J Natlcancer inst $1990.82,650-661$.

214: Valente PT, Schantz HD, Trabal JF. The determination of Papanicolaou smear adequacr using a seminguabtitative method to evaluate celluarity. Acta Cytol $1990 ; 34: 63$.

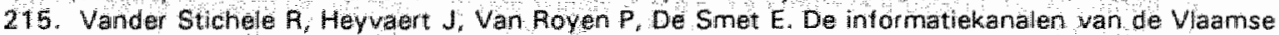
huisarts. Huisarts Au 1985; 14. 188.195.

216. Van Dooren P. Nieuwste Europose wersneller: Een racebaan voor geleerden. De standaard der Ietteren 1940.115 jul 1989 .

217. Wen WA van. Streening op cervixcarcinoom: naar optimallsering van de strategie. Huisarts Wet $1984 ; 27: 406 \% 411$

2118. Verby $J$ Holden $P$, Dawes $R$. Peer review of consultations in primary care. The use of audiovisual recordings. Br med J 1979; 1: 1686-1688.

219. Verhellen E, Vander Stichele R, Bouwerne-De Ble M, Dentef L, Peeters C. Medsche documentatie en bibliografie woor fiulstartsen, Gent: Rijksiniversteit, 1980.

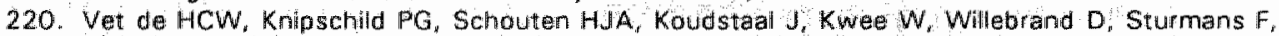
Arends JW. Interobserver variation an histo-pathological grading of cervical dysplasial $\mathrm{J}$. Clin Epidemiol 1990; 43 , 1395.1398:

221. Werhout ME. The multispatulat a spatula adjustable to the shape of the individual cervix. Eur $J$ Obst Gynecol $1987,26,343-347$

222. Voojis GP. Endocenvical brush dewice. Lancet 1989: 784.

223, Woolis GP. Significance of cellular composition of smears for the reliability of cy tological diagnosis. In: K. Goertlen, G. Fiechter, S. Witte led1. New Frontiers in Cytology. Berlin 1988:412-420.

224. Vooijs GP. Elias $A_{\text {; }}$ Graal $Y$ wan der. Poeten van de Berg M. The influence of sample takers on the cellular composition of cervical smears. Acta $C y t o 1$ 1986; 30:251-257.

225. Wooijs GP, Elias A, Graaf Y van der. Veling S. Relationship between the diagnosis of epithelial abmormalities and the composition ot cervical smears. Acta Cytol 1985, 29. 323-328.

226. Vooljs GP, Graa Y van der, Elias AG. Cellular composition of cervical smears in relation to the day af the menstrual cycle and the method of contraception. Actal Cytol 1987:31:417-426.

227. WUB Kankerpreventie. Overzicht vam de activiteiten van de dienst kankerpreventie VUB 1984. 1986 (intern rapport). Brussel; Gezandheidscentrum VUB: 1987.

228. Wachtel E, Gordom H. An improved sampling device for cervical cytology. Lancet 1974 $26-27$.

229. Ward MM, Pollisson RP. A meta-analysis of the clinical manifestations of alder-onset systemic lupus erythematosus. Arthritis Rheum $1989 ; 32: 1226-1232$.

230. Weyler J, Engels H. Gebruk van cervexbrush woor wroegopsporing van baamoederhalskanker: kwaliteit van het uitstrikje. Epidemiologie en Sociale Geneeskunde Universitaire instelling. Antwerpon (UIA.

231. Willocikx F, de Somer ML, Roy J van. Clas siflation of cervical smears with discordance between He cytologic andor histologio retings. Acta Cyto $1987,31,883-886$.

232. Willockx $F$, Roy J wen, Gebruik van Cytobrush bil de afmame van cerwautstrikjes. Tijdsch Belg Ver Labor 1989; $15111: 4748$.

233. Winlckof $\mathrm{A}$, Coltin $\mathrm{A}$, Morgan $\mathrm{A}$, e.: Improving phwsiciam performance through peer comparison leedback. Med Care $1984 ; 6: 527-534$.

234. Wolf F. Meta analysis: Ouantitative methods for research synthesis. In: Ouantitative applications in the social sclences (series) nf 59. Beverly Hils: Sage Publications 1986

235. Wolfendale MA. Howe-Quest H, Usherwood M, Draper GJ. Controlled trial of a new cervical spatula. Br Med J 1987; 294:33-5

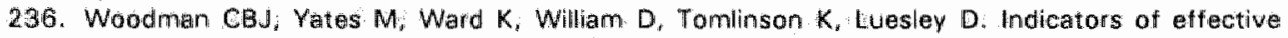
oytological sampling of the uterne cervix, Lancet $1989: 88-90$.

237. Yach. D. Meta-analysis in epidemiology. SAM 1990; 78:94-97.

238. Zimmer S, Krahneit U, Munck C. Zur Bedeutung var Fehlerquellen und Qualitätskontrollen im zytologischen Massenscreening. Zent Bl Gynaekal 1987; 109:209-217.

239. Zuna RE. The pap smear revisited: controversies and recent developments Postorad med 1984; 76: $36-46$. 
Tabel 8.4: Inviloed van de feed-back op het percentage uitstrijkjes zonder endocervicale en/of metaplastische cellen per arts. gerelateerd aan een aantal belangrijke covariabelen. Gerapporteerd worden het veranderingsquotiënt 1+ aantal artsen per groepl en het verschill 1+ $95 \%$ Bll tussen interventioperiode on basislijnperiode (n $=177$ artsenl.

\begin{tabular}{|c|c|c|c|c|c|c|c|c|c|c|}
\hline & \multicolumn{5}{|c|}{ Wer underingwatwotiant } & \multicolumn{5}{|c|}{ 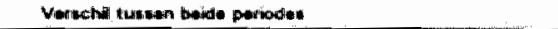 } \\
\hline & $A$ & E & c & $\mathbf{D}$ & Corr. & $A$ & B & c & 0 & Corr. \\
\hline Alle whown & $\begin{array}{l}0.69 \\
1331\end{array}$ & $\begin{array}{l}0.448 \\
{[341]} \\
\end{array}$ & $\begin{array}{l}0.40 \\
1291 \\
\end{array}$ & $\begin{array}{l}0.022 \\
1341 \\
\end{array}$ & -0.1160 & $\begin{array}{l}0.94 \\
1.13 ; 0\end{array}$ & $\begin{array}{r}10.36 \\
(-10,-5) \\
\end{array}$ & $\begin{array}{l}13.41 \\
(1.19 \cdot 6)\end{array}$ & $\begin{array}{r}-11.66 \\
80: 78 \\
\end{array}$ & $\infty .11$ \\
\hline Hhis ent wen & $\begin{array}{l}0.67 \\
{[30]}\end{array}$ & $\begin{array}{l}0.67 \\
|28|\end{array}$ & $\begin{array}{l}0.481 \\
1.271\end{array}$ & $\begin{array}{l}0.63 \\
\| 3 \pm \mid\end{array}$ & 0.111 & $\begin{array}{l}-9.74 \\
1.114:+16)\end{array}$ & $\begin{array}{l}-11,30 \\
(-\mid 18 ;-5)\end{array}$ & $\begin{array}{l}-14,07 \\
1.20,-81\end{array}$ & $\begin{array}{l}-12.30 \\
(18.7)\end{array}$ & 0.099 \\
\hline $\begin{array}{l}\text { Oynev- } \\
\text { Eokagen }\end{array}$ & $\begin{array}{l}0.8] \\
{[3]}\end{array}$ & $\begin{array}{c}0.78 \\
\|8\|\end{array}$ & $\begin{array}{l}0.20 \\
\| 2 \mid\end{array}$ & $\begin{array}{c}0.42 \\
1.31\end{array}$ & $\begin{array}{c}0.5 .90 \\
1 \% 1\end{array}$ & $\begin{array}{l}-0.80 \\
(12 ; 1101\end{array}$ & $\begin{array}{r}0.38 \\
017.41\end{array}$ & $\begin{array}{l}-4.52 \\
(235,6)\end{array}$ & $\begin{array}{r}.482 \\
1-11,11\end{array}$ & 0.273 \\
\hline Marnon & $\begin{array}{l}0.63 \\
\mid 261\end{array}$ & $\begin{array}{r}0.69 \\
4261\end{array}$ & $\begin{array}{l}0.37 \\
1221\end{array}$ & $\begin{array}{l}0.04 \\
1241\end{array}$ & $\$ 0.175$ & $\begin{array}{l}-110.45 \\
(-10 ;-6)\end{array}$ & $\begin{array}{l}=0.79 \\
(16: 39\end{array}$ & $\begin{array}{l}-13.312 \\
(120,-7)\end{array}$ & $\begin{array}{l}411.70 \\
1-10,-51\end{array}$ & 0.079 \\
\hline Wroumwn & $\begin{array}{c}0.91 \\
\| 71\end{array}$ & $\begin{array}{l}0.71 \\
181\end{array}$ & $\begin{array}{l}0.74 \\
|7|\end{array}$ & $\begin{array}{l}0.57 \\
1101\end{array}$ & 0.1612 & $\begin{array}{l}-3.30 \\
-10 ; 31\end{array}$ & $\begin{array}{l}12.30 \\
123.21\end{array}$ & $\begin{array}{r}-13.08 \\
-30.21\end{array}$ & $\begin{array}{l}-11,31 \\
(-118 ;-41\end{array}$ & 40.223 \\
\hline$\frac{\text { Techuriels: }}{\text { Diverce }}$ & $\begin{array}{c}0.70 \\
|4|\end{array}$ & $\begin{array}{l}0.50 \\
{[4]}\end{array}$ & $\begin{array}{l}0.20 \\
121\end{array}$ & $\begin{array}{l}0.54 \\
{[4]}\end{array}$ & 0.050 & $\begin{array}{l}-0.71 \\
{[-24: 111]}\end{array}$ & $\begin{array}{l}22.46 \\
(-72227)\end{array}$ & $\begin{array}{l}-13.78 \\
1.58 .914\end{array}$ & $\begin{array}{l}-1525 \\
-42: 12)\end{array}$ & 0.150 \\
\hline i spetal & $\begin{array}{l}0.54 \\
\lfloor 2\rfloor \\
\end{array}$ & $\begin{array}{l}1.04 \\
{[6]} \\
\end{array}$ & $\begin{array}{l}0.30 \\
\|4\|\end{array}$ & $\begin{array}{l}0.78 \mathrm{i} \\
|4|\end{array}$ & 0.405 & $\begin{array}{l}-28.23 \\
\{-232 ; 17 \%\}\end{array}$ & $\begin{array}{l}-1.00 \\
\mid-15 ; 921 \\
\end{array}$ & $\begin{array}{r}-24.3 \% \\
\| .52,3) \\
\end{array}$ & $\begin{array}{l}12,31 \\
1-45 \div 201 \\
\end{array}$ & 0.100 \\
\hline Cbr elloon & $\begin{array}{l}0.5 \mathrm{a} \\
\| 101\end{array}$ & $\begin{array}{c}0.52 \\
{[4]}\end{array}$ & $\begin{array}{c}0.42 \\
121\end{array}$ & $\begin{array}{l}0.5 .3 \\
\{8\}\end{array}$ & 0.100 & $\begin{array}{l}-10.12 \\
4.16 \pi-4)\end{array}$ & $\begin{array}{l}-12,41 \\
(-20,-3)\end{array}$ & $\begin{array}{l}-10.96 \\
179,57\end{array}$ & $\begin{array}{c}4.38 \\
+10,0.21\end{array}$ & 0.273 \\
\hline $\begin{array}{l}\text { Gecombitbir } \\
\text { morerde } \\
\text { spat of }\end{array}$ & $\begin{array}{l}0.50 \\
|6|\end{array}$ & $\begin{array}{c}0.43 \\
{[8]}\end{array}$ & $\begin{array}{l}0.718 \\
1101\end{array}$ & $\begin{array}{l}0.86 \\
\|1\|\end{array}$ & $0.01: 0$ & $\begin{array}{l}17.13 \\
1.29:-54\end{array}$ & $\begin{array}{l}-17.15 \\
(-22 ; 12)\end{array}$ & $\begin{array}{l}-11,00 \\
1.24: 11\end{array}$ & $\begin{array}{l}-16.20 \\
(-27 ;-6)\end{array}$ & -0.000 \\
\hline $\begin{array}{l}\text { Sp. } \\
\text { Con. }\end{array}$ & $\begin{array}{l}0.75 \\
|30|\end{array}$ & $\begin{array}{l}0.80 \\
|11|\end{array}$ & $\begin{array}{l}0.31 \\
1111\end{array}$ & $\begin{array}{c}0.58 \\
181\end{array}$ & $\begin{array}{c}0.352 \\
101\end{array}$ & $\begin{array}{l}3.00 \\
0.0,0.41\end{array}$ & $\begin{array}{r}5.01 \\
1.14 .41 \\
\end{array}$ & $\begin{array}{l}-11.45 \\
(-20: .7) \\
\end{array}$ & $\begin{array}{r}-8,60 \\
1-19,01\end{array}$ & $\begin{array}{c}0.342 \\
1 \% 1 \\
\end{array}$ \\
\hline $\begin{array}{l}\text { Thot wh } \\
26\end{array}$ & $\begin{array}{l}0.63 \\
0131\end{array}$ & $\begin{array}{l}0.106 \\
|1.3|\end{array}$ & $\begin{array}{l}\left.0.971^{\circ}\right) \\
17 !\end{array}$ & $\begin{array}{l}0.73 \\
|18|\end{array}$ & 0.045 & $\begin{array}{l}+1440 \\
122,01\end{array}$ & $\begin{array}{l}-15.50 \\
129.21\end{array}$ & $\begin{array}{r}21.37 \\
16.27\end{array}$ & $\begin{array}{l}.70,00 \\
1.19 ; 2)\end{array}$ & 0.037 \\
\hline $\begin{array}{l}\text { Tot, uht } \\
20.50\end{array}$ & $\begin{array}{c}0.68 \\
18 \|\end{array}$ & $\begin{array}{c}0.59 \\
171\end{array}$ & $\begin{array}{l}0.5 \| \\
\|12\|\end{array}$ & $\begin{array}{l}0.60 \\
\$ 100\end{array}$ & 0.020 & $\begin{array}{c}-0.44 \\
(-17,4)\end{array}$ & $\begin{array}{l}40.39 \\
(-17,0)\end{array}$ & $\begin{array}{l}-14,312 \\
(-20 ; 0)\end{array}$ & $\begin{array}{l}\| 11.31 \\
(2,1 ;-1)\end{array}$ & 0.102 \\
\hline $\begin{array}{l}\text { Tot: anit > } \\
\text { sio }\end{array}$ & $\begin{array}{l}077 \\
1 \geqslant 11\end{array}$ & $\begin{array}{l}0.76 \\
1141\end{array}$ & $\begin{array}{l}0.47 \\
|110|\end{array}$ & $\begin{array}{l}0.35 \\
0 * 1 \\
401\end{array}$ & $\begin{array}{c}-4.48 \\
1 * 1\end{array}$ & $\begin{array}{l}4.52 \\
40,04\end{array}$ & $\begin{array}{l}-0.37 \\
\mid-11: 21\end{array}$ & $\begin{array}{l}-675 \\
1.18 .3 y\end{array}$ & $\begin{array}{l}14,00 \\
1 \cdot 23+46)\end{array}$ & $\begin{array}{c}4.321 \\
14\end{array}$ \\
\hline
\end{tabular}

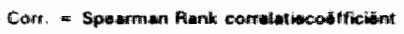

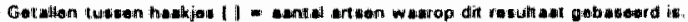

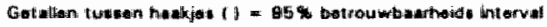

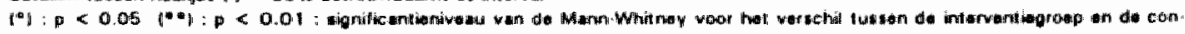

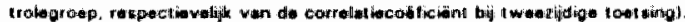

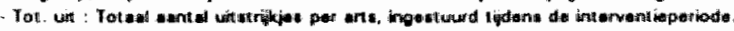

